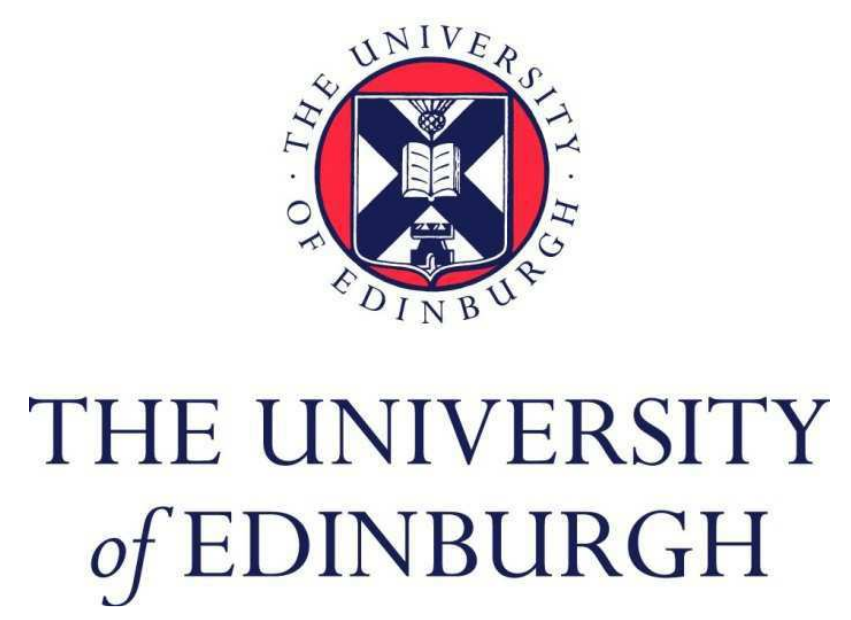

This thesis has been submitted in fulfilment of the requirements for a postgraduate degree (e.g. PhD, MPhil, DClinPsychol) at the University of Edinburgh. Please note the following terms and conditions of use:

This work is protected by copyright and other intellectual property rights, which are retained by the thesis author, unless otherwise stated.

A copy can be downloaded for personal non-commercial research or study, without prior permission or charge.

This thesis cannot be reproduced or quoted extensively from without first obtaining permission in writing from the author.

The content must not be changed in any way or sold commercially in any format or medium without the formal permission of the author.

When referring to this work, full bibliographic details including the author, title, awarding institution and date of the thesis must be given. 


\title{
The Ritual Dimension of Union with Christ in Paul's Thought
}

\author{
Yu Chen
}

Doctor of Philosophy

New Testament and Christian Origins

The University of Edinburgh 
This work is dedicated to the beloved memory of my mother, Jiang Li Qing, who instilled in me the love for learning.

May her memory be eternal.

Ai $\omega v i ́ \alpha \dot{\eta} \mu v \eta ́ \mu \eta$ 


\section{Table of Contents}

Abstract..........................................................................

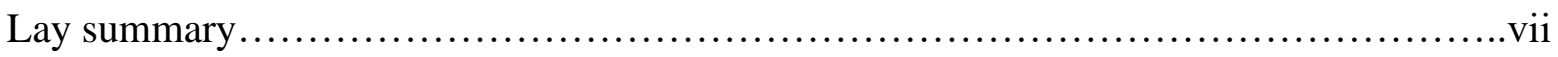

Abbreviations................................................................viii

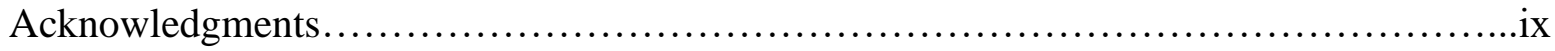

Chapter One: The Ritual Dimension of Union with Christ in Paul's Thought: Trends, Approaches, Method..........................................1

Chapter Two: Baptism as a Ritual Performance....................................37

Chapter Three: The Lord's Supper as a Ritual Performance.............................89

Chapter Four: The Ritual Dimension of Paul's

Participatory Language.

Chapter Five: Pistis and Ritual: Their Roles and

Relationship

Chapter Six: The Ritual Dimension of Union with Christ in Paul's Thought:

Divine-Human Relation

Bibliography 


\begin{abstract}
The study of the ritual (sacramental) aspect of participation in Christ has long been marginalised in the literature due to an anti-ritual bias that has several strands. Theologically, given the biblical studies conducted under Protestant, word-centred, faith-focused principles in the past two centuries, any serious study of ritual practices in the nascent Christ movement would face suspicion of opus operatum. Intellectually, the rational approach to the studies of religion, developed during the Enlightenment period that so prized human reason, has led to the downplaying of rituals as superstitious practices, viewing the body as an unreliable source for truth, as opposed to the structure of the mind, where truth is located. Methodologically, the historical-critical approach practised by the biblical studies guild and guided by text-centred and philologically focused principles, has resulted in the marginalisation of rituals in scholarship; ritual references are treated as a mere metaphor or a theological discourse. To give rituals their rightful place in the study of the New Testament, this study proposes that one needs to treat baptism and the Lord's Supper in the New Testament as ritual practices rather than mere metaphor, with the aid of frameworks and theories developed in ritual studies. Chapter one of this study surveys the current scholarship on the topic and develops a new theoretical framework, the ritual transformation model, to study baptism and the Lord's Supper. In chapters two and three, this study applies the ritual transformation model to study these two rituals, while chapters four and five address the exegetical issues of the relations amongst ritual, pistis, and "in Christ" language. In its conclusion, the study demonstrates that ritual and pistis are not antithetical to each other as body versus mind, that baptism and the Lord's Supper are the two cardinal practices of the early Christ movement, and that the New Testament texts point to the religious experience of early Christ followers' encounter with the risen messiah, an experience that is made accessible by the ritual performance.
\end{abstract}




\section{Lay Summary}

The study of "in Christ" language in New Testament scholarship has received widespread attention in recent years. Nevertheless, despite all the perspectives from which scholars have treated this topic, one aspect of "in Christ" language has received only scant attention: its ritual or sacramental aspect. There are several factors that contribute to the downplaying of ritual in New Testament studies. First is the ongoing theological polemics between Protestants and Catholics on the exact role of sacraments in relation to one's salvation in Christ. Second, a general trend in the intellectual tradition of the West since the Enlightenment period approaches religion in a rational manner, distrusting religious practices. Third, there is a heavy emphasis on the linguistic and historical aspects of biblical texts in biblical studies. Together, these factors have led to the downplaying of rituals like baptism and the Lord's Supper in the New Testament. To place the study of ritual in New Testament scholarship in its rightful place, this thesis develops the framework of a ritual transformation model from ritual theories. Given the close affinity between "in Christ" language as a religious experience and the ritual transformation model, this study indicates that using the ritual transformation model helps explain the manner and process of union with Christ whilst avoiding endless theological debates on the mode of the sacraments. Thus, this study focuses on the historical and social implications of the ritual performance of baptism and the Lord's Supper, which are used to explain the mechanisms of union with Christ. Furthermore, the use of the ritual model to interrogate the baptismal and eucharistic texts in question shows that these ritual references are not mere metaphors or a theological discourse that can be cited as a proof-text for certain doctrinal points. Rather, baptism and the Lord's Supper are the two most important ritual practices in the early church, providing to their participants a path to access the transformative experience of encountering the risen messiah. 


\begin{abstract}
Abbreviations
All abbreviations of ancient sources and secondary literature conform to Billie Jean Collins et al, eds., The SBL Handbook of Style: For Biblical Studies and Related Disciplines, 2nd ed. (Atlanta: SBL Press, 2014).
\end{abstract}




\section{Acknowledgements}

I am grateful to Paul Foster, under whose supervision I have received excellent support as a guide and an interlocuter in every step of my thesis project, from forming a proposal to the final draft.

A special thanks to Athanasios Despotis who gladly participated in the whole examination process, offering numerous suggestions, critiques, and proofreading for the improvement of the original manuscript. All remaining errors are mine.

I am grateful to other conversation partners who have shown great interest in the project and offered some helpful suggestions, especially Shamir Paulos Kamchi.

Finally, I am grateful to friends who offered support and encouragement throughout the project. 



\section{Chapter 1 \\ The Ritual Dimension of Union with Christ in Paul's Thought: Trends, Approaches, Methods}

\subsection{Introduction}

The genesis of current research on Pauline participatory soteriology can be traced to Adolf Deissmann, whose work brought the notion of being "in Christ" to the centre of New Testament studies. Following his lead, subsequent works have attempted, using various approaches, to determine the full implications of this notion. Some have focused on the concept of Pauline mysticism (theosis or deification, union) ${ }^{1}$ others have attempted to locate Pauline mysticism in the late Jewish apocalyptic tradition or in Hellenistic thought. Still, others have sought to relate other Pauline concepts such as justification, atonement, and Adamic Christology - to name just a few - to Pauline participatory soteriology in order to draw out different aspects of the same concept. Concerning this third approach, two recent works on the subject deserve mention: Blackwell's Christosis and Macaskill's Union with Christ in the New Testament. The former studies the Pauline participatory concept in connection with the anthropological dimension of Pauline thought under the constellation of the related themes of adoption, immortality, and incorruptibility by using the Wirkungsgeschichte method, whereas Macaskill approaches the subject through the overarching framework of a covenant, as informed by the Reformed tradition and historical theology.

Many questions, however, remain unexplored regarding other Pauline concepts in relation to being in Christ, such as the role of sacraments. In particular, the Pauline notion of rituals, such as baptism and the Last Supper, in connection with union with Christ, has received only scant treatment in Anglophone scholarship, as Morales has observed. ${ }^{2}$ The notion fares

\footnotetext{
${ }^{1}$ Regarding terminology, some scholars prefer not to use the terms theosis or deification to refer to Paul's participatory soteriology; they opt instead for a different nomenclature, since these terms are theologically loaded and strongly associated with Eastern Orthodox tradition. See Carl Mosser, "The Earliest Patristic Interpretations of Psalm 82, Jewish Antecedents, and the Origin of Christian Deification," JTS 56, no. 1 (2005): 31n3. Blackwell proposes the term Christosis, Gorman coins the term cruciformity, and Campbell proposes the conceptual quartet of union, participation, identification, and incorporation. Others, such as Stephen Finlan and David Litwa, have sought to redefine the term to give it a highly specific point of reference. The former seeks biblical support for the term in Christian doctrine discourse; see Stephen Finlan and Vladimir Kharlamov, eds., Theōsis: Deification in Christian Theology (Cambridge: James Clarke and Co., 2012), 1-15. The latter sets the concept within a culturaltheological framework that rejects the tight classical conception of monotheism in favour of a looser one that allows for the divinisation of humans; see M. David Litwa, We Are Being Transformed, 1. Aufl. ed., BZNW 187 (Berlin: De Gruyter, 2012). For the purposes of this study, we will use union to describe Paul's participatory soteriology, as it is closely related to the biblical language but does not carry the baggage of any theological traditions.

${ }^{2}$ Isaac Augustine Morales, "Baptism and Union with Christ," in "In Christ" in Paul: Explorations in Paul's Theology of Union and Participation, ed. Michael J. Thate et al. (Tübingen: Mohr Siebeck, 2014$), 161$.
} 
better in German-speaking scholarship. Eduard Lohse articulated the significance of baptism for understanding Pauline thought as follows:

If one considers the exceedingly frequent use of the formula "in Christ" in Paul, with which the apostle shows that the transfer to the Lord effected in baptism and the claim of the baptized by his Lord associated with it actually extends to all areas of life and puts the human being under the control of the Lord in his entire thinking, working, and action, then one can rightly characterize the whole of Paul's theology as an exposition baptism. ${ }^{3}$

Notwithstanding Lohse's overstatement of the role that baptism plays in Pauline thought (not all Paul's thoughts, such as the mission of Christ and the role of the Holy Spirit, derive from baptism), baptism and the Last Supper highlight some important elements of union with Christ, as Paul appeals to them on several occasions. Baptism highlights the close connection between this union with the unity of the body of Christ (1 Cor 10:16; 12:3), a new identity in Christ (Gal 3:27-28), and participation in Christ's salvific acts (Rom 6:1-6). Several questions arise. Do baptism and the Last Supper play a role in the process of uniting with Christ? What is the relation between these two rituals and Paul's participatory language? What is the relation between faith and sacraments or rituals? To answer these questions, we do not turn to the theological approach, as various traditions have understood the sacraments differently, especially regarding their mode of operation and their relationship to Christ's presence in the sacraments. The historical debates concerning the efficacy of and Christ's presence in the sacraments cannot be resolved through exegesis of key passages in the New Testament. Rather, we adopt a social-scientific approach, employing theories and models developed in the study of ritual, for the analysis of ritual may provide a way through this theological impasse. Instead of focusing on precise modes of operation, the present study focuses on the elements or functions of the ritual in relation to union with Christ. The cross-cultural models developed in ritual studies employ the categories of death, rebirth, purity, transformation, communion, and mediation, to name a few, and these overlap with how Christian rituals function. By using these models to analyse how baptism and the Last Supper function in the practice of the early church, the significance of the two rites are brought to the fore in the discussion of Pauline theology. Thus, baptism is treated as a ritual and not merely a theological metaphor, albeit one that needs distinction between the rite itself and the imagery with which Paul loads it.

There are two important qualifications regarding this study. First, the term sacrament, a highly theologically loaded word, does not appear in the New Testament. It is, however, an

${ }^{3}$ Eduard Lohse, "Taufe und Rechtfertigung bei Paulus," Kerygma und Dogma 11 (1965): 308-24, repr. in Die Einheit des Neuen Testaments: Exegetische Studien zur Theologie das Neuen Testaments (Göttingen: Vendenhoeck \& Ruprecht, 1973), 228-44, quoted in Morales, "Baptism and Union,” 159. 
etic term that has been used by scholars to refer collectively to baptism and the Last Supper, without presupposing any specific theological understanding of these two rites. Throughout the present study, the term sacrament will apply specifically to the early church's ritual practices of baptism and the Last Supper, without any theological presupposition of their modes of operation. Second, the terms sacrament and ritual are used interchangeably throughout the study, recognising that the former is a theological category and the latter a social-scientific category.

\subsection{The State of Scholarship}

Within biblical scholarship, the role of baptism and the Last Supper in Pauline theology has long been of only marginal interest. Some scholars have ascribed significance to baptism and the Last Supper, but only in fleeting references or in reinterpreting Paul's language of baptism as merely metaphorical. ${ }^{4}$ The following works on the role of sacraments in Pauline thought have exhibited just such a tendency.

\subsubsection{G. Adolf Deissmann}

Deissmann, dubbed the pioneer of Christ mysticism, ${ }^{5}$ writes emphatically that both baptism and the Lord's Supper do not bring about fellowship with Christ ${ }^{6}$ but are an outward expression of this fellowship. Holding that the theophany of Christ to Paul on the road to Damascus is a decisive moment when Paul establishes relations with Christ and that Paul is commissioned to evangelise to rather than baptise the nations, Deissmann argues that these two rites have no bearing on establishing fellowship with Christ. $^{7}$ Although in Paul's case the fateful encounter with the risen Lord has a lasting impact on his relationship with Christ, he is nevertheless instructed to be baptised afterwards, cementing the fellowship between Christ and Paul as a chosen vessel sent to the nations (Acts 9:10-19). Moreover, the argument that Paul is commissioned to evangelise but not to baptise, of which Paul himself remarks in 1 Cor 1:14, does not negate the fact that he does baptise people during his missions (1:15). The reason for this remark is Paul's rhetorical response to the divisions in the Corinthian community that weaponizes the baptismal ritual as a rallying cry for allegiance to different fractious groups.

\footnotetext{
${ }^{4}$ Cf. Constantine R. Campbell, Paul and Union with Christ: An Exegetical and Theological Study (Grand Rapids: Zondervan, 2012), 384-86, and James D. G. Dunn, “'Baptized' as Metaphor," in Baptism, the New Testament and the Church: Historical and Contemporary Studies in Honour of R.E.O. White, ed. Stanley E. Porter and Anthony R. Cross (Sheffield: Sheffield Academic Press, 1999): 294-310.

${ }^{5}$ E. P. Sanders, Paul and Palestinian Judaism: A Comparison of Patterns of Religion (Minneapolis: Fortress, 1977), 453.

${ }^{6}$ Adolf Deissmann, Paul: A Study in Social and Religious History, 2d ed., trans. Lionel R. M. Strachan (London: Hodder \& Stoughton, 1926), 130-31.

${ }^{7}$ Ibid., 131.
} 
We see Paul, with his mastery over rhetoric, respond to the accusations directed against him by Jewish leaders by claiming that he is a Pharisee (Acts 22:2-5; cf. Phil 3:5) Thus, it is possible that Paul would have baptised his audiences, ${ }^{8}$ especially communities founded by him, since baptism often follows the proclamation of the gospel. Finally, the premise that undergirds Deissmann's notion of "Christ mysticism" is individualistic and private, without the mediation of external means or a third party. This is in stark contrast to Paul's understanding of fellowship with Christ, which has a corporate dimension and a ritual setting. In 1 Cor 12:12-13 Paul speaks of baptism as a rite that initiates the Corinthians into the body of Christ. In 1 Cor 10:14-20

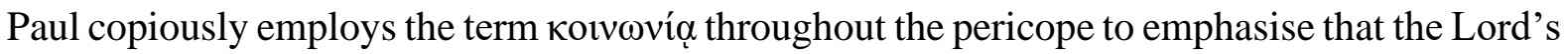
Supper establishes union with Christ. Three observations emerge from these two passages:

1. The preposition $\varepsilon i \zeta^{9}$ in 1 Cor 12:13 should be understood in a local sense, designating the sphere in which one is baptised. This signifies baptism as a rite of initiation that initiates the Corinthians into the Christ community.

2. The comparison drawn between the Lord's Supper and pagan sacrifice in 1 Cor 10:18-21 presupposes that Paul understands the former as a religious sacrifice that would make the participants partners of the divine beings present in the ritual (i.e., Christ and demons).

3. Both rituals have a corporate dimension. The baptism ritual has its aim the incorporation into the body of Christ, and Paul couches baptism within the overall framework of unity amongst the members of Christ's communities in 1 Cor 12. The corporate nature of the Lord's Supper is intimated by the series of first-person plurals attached to various ritual actions: $\varepsilon \hat{\lambda} \lambda \sigma \gamma o \tilde{v} \mu \varepsilon v, \kappa \lambda \tilde{\omega} \mu \varepsilon v, \dot{\varepsilon} \sigma \mu \varepsilon v$, and $\mu \varepsilon \tau \varepsilon \dot{\chi} \chi \mu \varepsilon v$.

Based upon these observations, Deissmann's notion of Christ mysticism, which is wholly individualist and private and lacks the mediation of ritual performance, is simply inadequate.

\subsubsection{Albert Schweitzer}

Current research on Paul's thought on participation in connection with the sacraments traces its starting point to Schweitzer's proposal that Pauline mysticism stands in stark contrast to Hellenistic mysticism. Instead of locating Paul's notion of the sacraments amongst the Hellenistic mysteries, Schweitzer argues that its origins are found in late Jewish eschatology, on the grounds that the external rites are the "assurance of future deliverance." 10 Thus, baptism is "an act which guaranteed the efficacy of repentance, as a preparation for the outpouring of the Spirit and for the salvation at the Judgement," 11 and the Last Supper is "a mystical anticipatory celebration of the Messianic feast." 12 The Hellenistic sacramental conception is,

\footnotetext{
${ }^{8}$ Although we are uncertain whether Paul baptised all his audiences during his missionary activities, he did perform the baptism ritual on at least some who heard his preaching (1 Cor 1:16; cf. Acts 18:8).

${ }^{9}$ See section 2.5.3 below for why the preposition denotes a movement into a sphere. See also Stanley E. Porter, Idioms of the Greek New Testament, 2d ed. (Sheffield: Sheffield Academic Press, 1994), 151.

${ }^{10}$ Albert Schweitzer, The Mysticism of Paul the Apostle, trans. William Montgomery (London: Adam and Charles Black, 1953), 228-29.

${ }^{11}$ Ibid., 233.

12 Ibid., 251.
} 
on the one hand, atemporal, "profess[ed] to be able to manifest their power in all generation" from primitive antiquity; on the other hand, Paul's sacramental conception has temporal boundaries whose "power is derived from the events of the last times." 13 Schweitzer further observes that Paul predicates his conception of the sacrament on his teaching of the "mystical being-in-Christ"; ${ }^{14}$ that is, baptism is a participation in Christ's death and resurrection and the Last Supper, whose acts of "eating and drinking signif[y] union with Christ." ${ }^{15}$ Regarding the question of the necessity of the sacrament, however, Schweitzer observes that, although Paul's doctrine of redemption is closely connected with the sacrament, the latter "can be thought of apart from them [the sacraments], since the whole mystical doctrine of fellowship with Christ rests upon the single conception of faith." ${ }^{" 16}$ In other words, it is faith that affects the union with Christ and not rituals, whose function is that of "externalisation, not of intensification."17

\subsubsection{Alfred Wikenhauser}

In contrast to Schweitzer's stance associating the sacraments with union with Christ, Wikenhauser asserts that it is baptism that effects the union with Christ, while faith is the proper condition through which the believer receives the baptism. Wikenhauser points out that most Protestant scholars "take no account of a real objective fellowship of life and being between Christ and Christians" established by a sacramental act, namely baptism. ${ }^{18}$ In support of this,

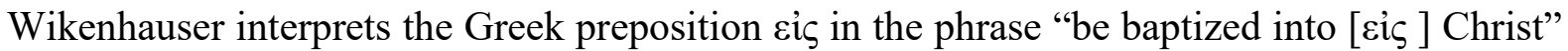
as having a locative sense; the whole phrase thus "means to be plunged or sunk into the Person of Christ." ${ }^{19}$ He unequivocally declares that "Baptism, and not faith, establishes the mystical relationship with Christ." ${ }^{20}$ Faith - understood as confident trust in God, who will complete the work of redemption in believers - means an intellectual assent to the content of the Gospel's message and obedient subjection to the precepts of the Gospel in daily conduct. ${ }^{21}$ Furthermore, faith is a necessary condition for receiving baptism, for it entails one's acceptance of the gospel before entering into a relationship with Christ through baptism.

${ }^{13}$ Albert Schweitzer, Paul and His Interpreters: A Critical History, trans. William Montgomery (London: Adam and Charles Black, 1912), 216.

${ }^{14}$ Schweitzer, Mysticism of Paul, 261-62.

15 Ibid., 268-69.

${ }^{16}$ Schweitzer, Paul and His Interpreters, 214.

17 Ibid., 215.

${ }^{18}$ Alfred Wikenhauser, Pauline Mysticism: Christ in the Mystical Teaching of St Paul, trans. Joseph Cunningham (New York: Herder \& Herder, 1960), 110.

${ }^{19}$ Ibid., 111.

${ }^{20}$ Ibid., 123.

${ }^{21}$ Ibid., 128-29. 


\subsubsection{Wilhelm Bousset}

Another exception to the general trend of downplaying the role of ritual in Paul's thought is Bousset's Kyrios Christos. Commenting on Romans 6, he observes that Paul connects Christ mysticism to the baptism ritual understood as an act of initiation. The intimate relation between the participants and Christ is achieved through baptism. Bousset further observes that although this is analogous to the ancient mysteries in some fashion, Paul "frees that cultic experience, which had been understood only in the mood of a mystery, from its gloomy ties, reorients it to the personal, interprets it spiritually-ethically, and enlarges it." ${ }^{22}$ Similarly, he sees Paul as joining Christ mysticism with the baptism ritual in Gal 3:26-27, using the imagery of "clothed with the deity." ${ }^{23}$ Again, Paul's mysticism differs from that of ancient mysteries, since the former is interwoven "with the purely intellectual ideas of the apostle about faith." 24 The notion of union with Christ accomplished through baptism is tantalising, but Bousset does not develop this idea further, leaving us with only a germ of an idea.

\subsubsection{E. P. Sanders}

Alarmed by Schweitzer's use of the language of opus operatum, ${ }^{25}$ Sanders downplays the ritual significance of baptism by devoting little space to the discussion of baptism in relation to participation: there are only four relevant entries in the index to Paul and Palestinian Judaism. ${ }^{26}$ Within these sporadic treatments of Pauline baptism, Sanders raises the possibility that baptism and the death of Christ should be connected with the soteriology of cleansing that Christians receive as a preparation for future salvation and suggests that the concept of the body of Christ that appears in 1 Cor 12:12 is also present in the baptism and the Last Supper. However, Sanders makes these fleeting remarks about baptism without developing fully how the sacraments relate to Paul's notion of participation in Christ. ${ }^{27}$

${ }^{22}$ Wilhelm Bousset, Kyrios Christos: A History of the Belief in Christ from the Beginnings of Christianity to Irenaeus, trans. John E. Steely (Nashville: Abingdon, 1970), 157.

23 Ibid., 158.

${ }^{24}$ Ibid., 158.

${ }^{25}$ Morales notes that Schweitzer's usage of opus operatum in Paul and His Interpreters has nothing to do with the traditional theological concept, in which misuse of the term contributes to the marginalisation of the role of baptism and the Lord's Supper in many treatments of Paul's writings and thought. See Morales, "Baptism and Union," $158 \mathrm{n}$

${ }^{26}$ E. P. Sanders, Paul and Palestinian Judaism, 14, 434, 452, 456; Richard B. Hays made this observation in "What is 'Real Participation in Christ?"” in Redefining First-Century Jewish and Christian Identities: Essays in Honor of Ed Parish Sanders, ed. Fabian E. Udoh et al., CJAS 16 (Notre Dame: University of Notre Dame Press, 2008), 336-51.

${ }^{27}$ Sanders, Paul and Palestinian Judaism, 522-23. 


\subsubsection{Herman N. Ridderbos}

Ridderbos continues the trend of intellectualising the notion of union with Christ by arguing that, instead of interpreting "in Christ" language in a mystical sense that is relegated to certain moments of experience such as rites and ceremonies, the notion of union with Christ should be grounded in the "objective' state of salvation" that is "included in the historical death and resurrection of Christ himself." ${ }^{28}$ For Ridderbos, to be in Christ is to be included in the Christ events of death and resurrection. This view immediately raises the question of the means by which one is to be included in these salvific events of Christ in order to be united with Christ? However, Ridderbos does not answer that question since it appears that he would have understood this to be accomplished through a mental grasp of faith in Christ.

In objectifying the notion of union with Christ as a "state of salvation," Ridderbos makes a dichotomy between the concept of union with Christ and that of spiritual experience that one participates in. We propose that ritual bridges the gap between the cerebral mode of participation in Christ and the somatic experience of the transformation in ritual participation. Rikard Roitto, adopting the recent developed theory of Cognitive Science of Religion (CSR), demonstrates that our cognition of divine is formed by the interaction of a thinking subject and their environment and on the analogy with concrete social experience. ${ }^{29}$ This applies to the formation of Pauline notion of "in Christ" whose foundation is built and shaped by the ritual experience of early Christ movement. In particular, baptism and the Lord's Supper play a significant role in giving rise to the concept of "in Christ." Paul's baptismal language of

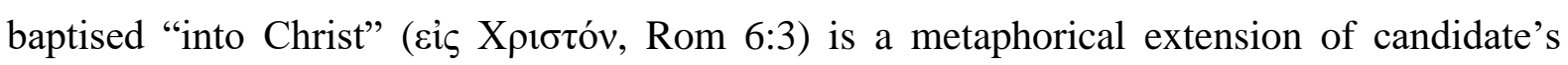
concrete bodily experience of going down into water and coming back up from the water contained in the ritual space. ${ }^{30}$ Similarly, Paul's language of fellowship with Christ and with members of Christ's body finds its basis in the concrete social experience of meal ritual. In the meal ritual, the participants experience Christ's presence "in a highly embodied way" through the partaking of bread and wine, which has indexical relation to Christ. ${ }^{31}$ Furthermore, the sense of intimacy amongst the participated is cultivated by the "very format of the triclinium (dining room)," "an enclosed space with the couches along the walls so that the focus of all

\footnotetext{
${ }^{28}$ Herman N. Ridderbos, "In Christ, with Christ: The Old and the New Man," in Paul: An Outline of His Theology, trans. John Richard De Witt (Grand Rapids: Eerdmans, 1997), 57-64.

${ }^{29}$ Rikard Roitto, "Paul's Theological Language of Salvation as Social and Embodied Cognition." In Participation, Justification, and Conversion: Eastern Orthodox Interpretation of Paul and the Debate Between "Old and New Perspectives on Paul", edited by Athanasios Despotis (Tübingen: Mohr Siebeck, 2017), 355-75.

${ }^{30}$ Roitto, "Paul's Theological Language," 63, 72-3.

${ }^{31}$ Ibid., 71-2.
} 
participants was towards the centre of the room."32 Thus, these two examples show that ritual is the locus point of divine cognition (theology) and religious experience of the divine. In Chapter four we will discuss in detail how ritual mediates these two modes of participation in the divine.

\subsubsection{Michael J. Gorman}

Gorman has briefly taken up the issue of rituals and faith in relation to union with Christ. Commenting on Rom 6:1-7:6 in connection with Gal 2:15-21 under the theme of justification as co-crucifixion, Gorman briefly addresses the relationship between faith and baptism:

Rather, it shows that for Paul faith and baptism are theologically coterminous, and faith is the essence of baptism even as baptism is the public expression of faith. Thus, what Paul predicates of faith he can also predicate of baptism, and vice versa, because together they effect, at least from the perspective of the human response, transfer into Christ and thus participatory justification in him. ${ }^{33}$

Instead of conceiving faith and works or baptism in this context as two different categories, with one or the other being dominant or one being subsumed into the other (and in this case baptism is the outworking expression of faith), we conceive of them as referring to a single reality with two different dimensions. Evidently, Paul understands $\pi$ í $\sigma \tau \iota \varsigma$ [faith] as a love ethic that expresses its efficacy in action: "For in Christ Jesus neither circumcision nor uncircumcision is of any avail, but faith working through love" (Gal 5:6).

\subsubsection{Constantine R. Campbell}

Campbell also affirms that the sacraments do not affect or actualize union with Christ, whatever the significance of these symbols might be. ${ }^{34}$ He presents two views from either end of a spectrum of sacraments and union with Christ. The first sees baptism and the Last Supper as having no reference to union with Christ, with the former being a metaphor when Paul speaks of it. The second sees the sacraments as "the means through which believers participate with Christ in death" (baptism) and "communion with Christ" (the Last Supper). ${ }^{35}$ Campbell mediates between the two ends of this spectrum by affirming that, when Paul speaks of being baptised in Christ, he is speaking metaphorically, but that the Last Supper, with its eating and drinking, has symbolic content:

\footnotetext{
${ }^{32}$ Ibid., 71

${ }^{33}$ Michael J. Gorman, Inhabiting the Cruciform God (Grand Rapids: Eerdmans, 2009), 79.

${ }^{34}$ Campbell, Paul and Union, 387.

35 Ibid., 385.
} 
This means that when Paul speaks of being baptized into Christ's death, he refers to baptism metaphorically. He does not imply that union with Christ is effected through the act of baptism, as though it is some sort of initiation rite. Union with Christ is effected by faith.

Concerning the Lord's Supper, it is difficult to deny that its symbolic content is at least suggestive of union with Christ [...] However, it probably goes too far to regard the Lord's Supper - in Paul's mind at least - as an actual act of sharing in Christ's death rather than simply symbolic of such. ${ }^{36}$

This tendency to downplay the symbolic content of baptism and the Last Supper stems from the assumption that metaphors involve secondary and nonliteral usages that extend beyond the original, literal meaning(s) of the term(s) in question. As a result, these commentators often treat baptismal language in the New Testament as metaphorical rather than treating the baptism ritual as a ritual. ${ }^{37}$ These anti-ritual biases in contemporary scholarship have led to the marginalisation of baptism and the Last Supper in Pauline scholarship. Indeed, it is not an exaggeration to state that the understanding of early Christian rituals has suffered because of antimetaphorical biases in scholarship. There is a longstanding tradition in Western philosophy of distrusting metaphor as a vehicle for truth and viewing it instead as mere ornament used to buttress rhetorical prowess. ${ }^{38}$ However, the tide has turned in recent decades, as numerous philosophers, linguists, and anthropologists have sought to rehabilitate metaphors as meaningful, cognitive, and even foundational to the understanding of society. ${ }^{39}$ This includes understanding rituals as metaphorical and metonymic. ${ }^{40}$

Rituals are the actualisation of root metaphors in society. Recent theoretical and ethnographic literature has demonstrated that metaphor not only infuses two concepts in creating similarities of a new kind but also lies at the root of linguistic conception. ${ }^{41}$ Since metaphors have an impact on language and thought, social practices reflect the metaphors that dominate language and thought. One of the ways metaphors are actualised in social practices is rituals that govern and regulate the outworking of a society. In a ritual, a series of sign-

36 Ibid., 386.
${ }^{37}$ Dunn, "“Baptized' as Metaphor."
${ }^{38}$ See Ted Cohen, "Metaphor and the Cultivation of Intimacy," Critical Inquiry 5, no. 1 (1978): 3-5; George Lakoff and Mark Johnson, Metaphors We Live By (Chicago: University of Chicago Press, 1980), 189-92; and Dan R. Stiver, The Philosophy of Religious Language: Sign, Symbols, and Story (Malden, MA: Blackwell, 1996), 8-13, 112-14.

${ }^{39}$ Stiver, Philosophy of Religious Language, 112-33; Lakoff and Johnson, Metaphors We Live By; Eva Feder Kitty, Metaphor: Its Cognitive Force and Linguistic Structure (Oxford: Clarendon Press, 1987); James W. Fernandez, Persuasions and Performances: The Play of Tropes in Culture (Bloomington: Indiana University Press, 1986), 3-70; and Claude Lévi-Strauss, Totemism, trans. Rodney Needham (Boston: Beacon Press, 1962).

${ }^{40}$ See Fernandez, Persuasions and Performances, 21-23, 41-50; Clifford Geertz, The Interpretation of Cultures: Selected Essays by Clifford Geertz (New York: Basic Books, 1973), 412-53; Lakoff and Johnson, Metaphors We Live By, 233-35; Victor Turner, Dramas, Fields, and Metaphors: Symbolic Action in Human Society (Ithaca: Cornell University Press, 1974), 23-59; and Howard Eilberg-Schwartz, The Savage in Judaism: An Anthropology of Israelite Religion and Ancient Judaism (Bloomington: Indiana University Press, 1990), 119, 122-29.

${ }^{41}$ Lakoff and Johnson, Metaphors We Live By. 
images or metaphors are "put into operation by a series of superordinate and subordinate ceremonial scenes." 42 Each of these scenes predicates on the participants the effects thereof by incorporating them into certain frames of reference like birth and death. By performing these scenes, the rituals bring about a transformation of the participant's experiences.

By applying this understanding of rituals as living out the implications of root metaphors in society to rituals in the early Christ community, one no longer sees metaphors as merely ornamental rhetoric but as actualisations of the root metaphors that produce a new community.

According to Howard Eilberg-Schwartz, revolutions in thought and practice are linked to the displacement of one root metaphor by another. As such, a change in operative metaphors that have shaped the social practice of a community will produce a new community. Accordingly, the emergence of the Christ movement was, to some extent, the result of a change in the operative metaphor in the Israelite religion whose source of metaphor is drawn from herds and flocks to the body of Christ. ${ }^{43}$ Under this new metaphoric system, individuals are conceived as members of Christ's body, figuratively undergo the death and resurrection of Christ, and consume Christ's flesh and blood. To express and validate this new metaphoric system, the rituals of baptism and the Last Supper perform these metaphors and the images entailed therein. The metonymies involved in these ritual activities - water, bread, wine, Christ event, immersion, eating, and drinking - form the same frame in the chain of experience carried out by the succession of ritual actions. These metaphoric predications enable the participants to experience the transformation brought about by these sign-images within the overall syntagmatic chain of ceremonial scenes.

\subsubsection{Grant Macaskill}

Compared with the scholars discussed above, Macaskill ascribed great significance to the sacraments in connection with the Pauline notion of participation. He links the sacraments to union with Christ by highlighting their covenantal nature, which "allows participants to identify themselves with one another and with a representative, whose story becomes theirs." 44 This identification is made possible by the presence of the Holy Spirit "in actualizing the story of Jesus in the life of his people." 45 Thus, Paul's usage of baptism imagery in Rom 6 signifies “a

\footnotetext{
${ }^{42}$ Fernandez, Persuasions and Performances, 42.

${ }^{43}$ Eilberg-Schwartz, Savage in Judaism, 138-40. 192.

${ }^{44}$ Grant Macaskill, Union with Christ in the New Testament (Oxford: Oxford University Press, 2013), ${ }^{45}$ Ibid., 192.
} 
ceremony of formalization" in which believers identify themselves "as dead and risen under the terms of the covenant on account of the representative work of Jesus." 46 Moreover, this identification entails a status change: believers are clothed with Christ when they are being baptised into him, sharing in the identity of Christ as children of God through divine adoption. ${ }^{47}$ As for the Last Supper, Macaskill identifies Paul's account of the Last Supper in 1 Cor 10:1422 and 1 Cor 11 with the Jewish Seder by recalling the Exodus narrative (10:1-15) as covenantal. The personal identification with a covenant representative is clear: "just as the Seder involves identification of the participant with those taking part in the Exodus, so believers identify themselves with the death of Jesus in their taking of 'body' and 'blood.",48

Regarding the actual relationship between the sacraments and union with God, Macaskill has this to say:

Secondly, the symbolic dimensions of the sacraments do not operate in isolation from the divine presence. The presence and activity of the Spirit, already emphasized in our study of the temple images, ensure that the sacraments are understood as a true participation in Christ, by which his narrative becomes truly realized in believers. A "vertical" communion with him maintained by the Spirit is the grounds for personal transformation. ${ }^{49}$

While avoiding the theological debates regarding the efficacy of the sacraments, Macaskill affirms that the sacraments play a role in participation in Christ, provided that this is understood in terms of an identification with Christ's narrative that is facilitated by the divine presence. By describing the sacraments "as a true participation in Christ," Macaskill swims against the tide of biblical scholarship, which has tended to downplay their significance. However, due to limitations of space, he devotes only a chapter to the sacraments, thus inviting further study.

\subsubsection{Conclusions}

Some key observations emerge from this review of the literature on the sacramental aspects of Pauline participatory soteriology. First, the current scholarly debates on baptism in the theological context can be divided into two poles: either the Pauline language of baptism is a metaphor, or it is a description of an initiation rite into which believers are incorporated into Christ. Second, in reaction to Schweitzer's strong interpretation of baptism and the Last Supper, most Protestant scholars agree that faith is what unites believers into Christ, whereas baptism is merely an external ceremony demonstrating that which is already grasped by faith internally and intellectually. A notable exception in this regard is Alfred Wikenhauser, a Roman Catholic

\footnotetext{
${ }^{46}$ Ibid., 196.

${ }^{47}$ Ibid., 196.

${ }^{48}$ Ibid., 206-07.

${ }^{49}$ Ibid., 217.
} 
scholar who argues that baptism, not faith, mystically unites believers with Christ in an objective event, separate from faith, as a prerequisite condition to receiving the baptism. Third, there is an increasing trend amongst Protestant scholars to take the language of baptism seriously. This can be seen in Campbell, who regards the language of baptism as a physical sign pointing to the act of baptism as union with Christ through his death, and in Macaskill, who frames baptism language in the context of the covenantal relationship with Jesus, with whom believers are personally identified. Finally, this literature review on the sacraments reveals a serious lacuna in the scholarship in terms of treating Paul's language of baptism and the Last Supper as religious rituals that facilitate the divine-human interaction; that is, union with God. ${ }^{50}$

\subsection{Methodology}

This thesis proposes that employing models from the study of rituals will help bring baptism and the Last Supper to their correct place in Pauline studies regarding participation in Christ. There are two justifications for this approach. First, the participatory language in Paul's writing is the language of religious experience (specifically, the Christophany on the road to Damascus) ${ }^{51}$ from which he derives much of his theology, including the notion of union with Christ. In many instances, Paul includes both himself and his readers in claims of experiencing Christ's redemptive acts in their lives. ${ }^{52}$ As Johnson observes, these claims to experience in the New Testament are not based solely on what has happened in the past or on a yearning desire for what the future might hold, but "on the witness of present participants." 53 The present study will show that the immanence of religious experience highlights the present reality of those who have been united with Christ through baptism and the Last Supper, as Paul reminds his readers in the epistles (Rom 6:3-4; 1 Cor 10:16; 12:13; Gal 3:27). Therefore, to do justice to this register of the language of experience, one cannot simply treat it as a prooftext for systematic theology under the headline of deification or sanctification. This point leads to the second justification for the present study's proposed approach. Theories and models of ritual have developed from the careful study and thoughtful observation of rituals across a full

\footnotetext{
${ }^{50}$ Frank Gorman outlines three strands of discourse that developed in the history of critical biblical studies and that marginalise ritual study in biblical scholarship: the Reformation discourse on theology, the rational discourse on religion, and the historical-critical discourse on method; see Frank H. Gorman, Jr., "Ritual Studies and Biblical Studies: Assessment of the Past; Prospects for the Future," Semeia 67 (1994): 14-20.

${ }^{51}$ See Seyoon Kim, The Origin of Paul's Gospel (Tübingen: Paul Siebeck, 1981), and Paul and the New Perspective: Second Thoughts on the Origin of Paul's Gospel (Grand Rapids: Eerdmans, 2002).

${ }^{52}$ See Rom 5:5; 6:11, 22; 8:15; 1 Cor 3:16; 5:4; 12:3-11, 27-31; 14:5-32; 2 Cor 3:18; 4:12; 12:12; 13:3, 5; Gal 3:2-5; 4:6-7, 9; 5:1; Phil 2:1; 1 Thess 1:5-6; 5:19. Luke Timothy Johnson, Religious Experience in Earliest Christianity: A Missing Dimension in New Testament Studies (Minneapolis: Fortress Press, 1998), 5.

53 Johnson, Religious Experience, 5-6.
} 
spectrum of religious traditions in a wide range of cultures; the aim of these rituals, regardless of origin or difference in detail, is to tap into the power of transcendence for the betterment of an individual or group. Theories and models of ritual, then, include not only the social dimension of rituals but also the "trans-human factor." 54 The theories and models selected for this study include both these elements, which seek to explain various aspects of divine-human interactions. By applying these ritual theories to the study of baptism and the Last Supper, the present study will deepen our understanding of the early church's rites, and the interpretation of one of the major motifs in Pauline thought - union with Christ - will be sharpened.

How, then, can one undertake a ritual analysis of biblical texts using theories and models of ritual that have emerged in recent scholarship? Frank Gorman has outlined in general terms three issues to which one must pay heed in this effort:

First, the relationship between the interpreter and the text must be under continuous review.... There are two interrelated questions: (a) What does the text bring to and call for in the interpretive process? and (b) What does the interpreter bring to and call for in the interpretive process? Second, the relationship between "text" and "ritual" must be reconsidered. Is there a middle ground between "text" and "ritual" that could bring productive results in the attempt to understand ritual texts? Can something of the enacted ritual be construed on the basis of ritual texts? Third, ritual texts seem to demand an imaginative construal of both the rituals depicted and the world within which the rituals take shape. An interpretive stance that envisions enactment and imaginatively construes a ritual world is needed..$^{55}$

The first issue implies that the method of analysis must include a means for "distinguishing and clarifying the differences between the social location of the interpreter and the social location of the authors and objects to be interpreted." In anthropological terms, one needs to identify information provided by natives in their accounts of their socio-economic locations (the emic dimension) and, by employing cross-cultural models from the perspective of the interpreter, to seek reasons why natives behave in certain ways (the etic dimension). Applying this to the investigation of ritual texts, the present study pays heed to the wider Hellenistic world in which the New Testament appeared and that informs its language of ritual while also employing cross-cultural models. Second, it examines various ways in which ritual and text are interwoven. Finally, on the basis of the data available in the New Testament and informed by the early Christian texts that mention ritual practices and the larger Greco-Roman context, it seeks to construe the ritual form of baptism and the Last Supper in the early church and the ritual world of which the New Testament forms a part.

\footnotetext{
${ }^{54}$ See Thomas F. Best, "The Sociological Study of the New Testament: Promise and Peril of a New Discipline," SJT 36, no. 2 (1983): 192.

${ }^{55}$ Gorman, Jr., "Ritual Studies," 21.
} 


\subsubsection{What is Ritual?}

Before outlining a programme of analysis for ritual texts in the Pauline epistles, we need to attend to more general issues, including the definition of ritual. A single definition of ritual that captures all its characteristics appears to have eluded scholars, as several ritual studies scholars have attested. ${ }^{56}$ In particular, Jan Snoek and Ronald Grimes address the issue and propose a working solution to the slipperiness of formally defining ritual. Snoek regards the confusion over the definition of ritual as deriving from the "naïve conception of what a definition should be. ${ }^{~} 57$ He then introduces a more sophisticated modern classification theory to tackle the issue. Besides the traditional, Aristotelian classes that are based on discrete characteristics possessed by every member of a class, there are also "fuzzy sets" and "polythetic classes." The former is composed of a class of objects that are characterised by a continuum of grades of membership ranging from zero to one. The latter is based on characteristics that may or may not be present. ${ }^{58}$ Rituals exhibit characteristics that are either on a continuum of grades, or they have some but not all characteristics; nevertheless, they are still recognisable as rituals. Snoek proposes that creating a working definition of the term requires cataloguing a set of characteristics that can be used to define ritual and decide on the purpose and context in which that set of characteristics should be used. ${ }^{59}$ Similarly, recognising the ever-elusive nature of ritual because it is a scholarly construct rather than a permanent essence, Grimes adopts a pragmatic approach, conceding that in some contexts a formal definition is called for "where boundaries are hedged, as it were, with barbed wire," whereas "a set of family resemblances is probably more useful in situations where boundaries are faintly marked." ${ }^{60}$ Grimes gives a succinct definition of ritual - "Ritual is embodied, condensed, and prescribed enactment" ${ }^{61}$ - and a list of family characteristics of ritual. ${ }^{62}$ The solutions proposed by these two scholars mediate between seeking a universal definition of ritual including all the characteristics of the class and jettisoning definitions altogether because they represent the "particular hegemony of western

${ }^{56}$ Risto Uro, "Introduction: Ritual in the Study of Early Christianity," in The Oxford Handbook of Early Christian Ritual, ed. Risto Uro et al. (Oxford: Oxford University Press, 2019), 5-7; Jan A. M. Snoek, "Defining 'Rituals,"' in Theorizing Rituals: Issues, Topics, Approaches, Concepts, ed. Jens Kreinath et al. (Numen 114; Leiden: Brill, 2008), 3-14; Ronald L. Grimes, The Craft of Ritual Studies (Oxford: Oxford University Press, 2014), 166-83; William S. Sax, "Ritual and the Problem of Efficacy," in The Problem of Ritual Efficacy, ed. William S. Sax et al. (Oxford: Oxford University Press, 2010), 3-16.

${ }^{57}$ Snoek, "Defining 'Rituals,", 3.

${ }^{58}$ Ibid., 4-6.

${ }^{59}$ Ibid., 10-13.

${ }^{60}$ Grimes, Craft of Ritual Studies, 196.

${ }^{61}$ Ibid., 196.

${ }^{62}$ Ibid., 194. 
intellectual life" 63 or are "dangerous" and "reductionist." 64 Rather, they take a pragmatic approach to the issue by selecting a working definition that is suitable to "analys[e] the phenomena under scrutiny from a ritual point of view." 65

For the purpose of this study, any definition of ritual should include the characteristics that define the divine-human relationship in a ritual. We create a collection of characteristics that can be used in the existing literature and turn to the ritual theories that employ the concepts of ritual as action, performance, and practice for collecting the kind of characteristics that can be used to analyse the phenomena of ritual participation in the nascent Christ adherents' experience. The rationale behind selecting this group of theories is that the structural and semiotic understanding of ritual that focuses on the rule-bound, formal, and referential qualities of rites and ritual cannot adequately account for the processual, strategic and efficacious qualities of ritual action, especially in studying early Christ-adherent communities of transformation and change. ${ }^{66}$ In this regard, action- and performance-oriented theories may offer new insights into the ritual life of the early church that other theoretical paradigms cannot:

Religious rituals ... are those religious actions whose structural descriptions include a logical object and appeal to a culturally postulated superhuman agent's action somewhere within their overall structural description. ${ }^{67}$

[Ritual is] the performance of more or less invariant sequences of formal acts and utterances not entirely encoded by the performers logically entails ... the generation of the concept of the sacred and the sanctification of conventional order. ${ }^{68}$

Insofar as ritual can be conceived as a technological virtualizing practice, a virtual reality machine, it is a device for entering into human actualities and is an opening and slicing into actuality. ${ }^{69}$

Ritual performance, as an enactment of exceptional relationships, imposes itself upon the participants as an incontestable personal and social experience, numerous features of which contribute to its presumed meaningfulness. ${ }^{70}$

It is precisely the emergence of realities in performance and their movement into the domain of social historical events which constitutes the movement of ritual or symbolic efficacy into the human world. ...

${ }^{63}$ Catherine Bell, Ritual Theory, Ritual Practice (Oxford: Oxford University Press, 1992), 6.

${ }^{64}$ Philippe Buc, The Dangers of Ritual: Between Early Medieval Texts and Social Scientific Theory (Princeton: Princeton University Press, 2001).

${ }^{65}$ Uro, "Introduction: Ritual," 5.

${ }^{66}$ Barry Stephenson, "Ritual as Action, Performance, and Practice," in The Oxford Handbook of Early Christian Ritual, ed. Risto Uro et al. (Oxford: Oxford University Press, 2019), 49-52.

${ }^{67}$ E. Thomas Lawson and Robert N. McCauley, Rethinking Religion: Connecting Cognition and Culture (Cambridge: Cambridge University Press, 1990), 176.

${ }^{68}$ Roy A. Rappaport, Ritual and Religion in the Making of Humanity, Cambridge Studies in Social and Cultural Anthropology 110 (Cambridge: Cambridge University Press, 1999), 27.

${ }^{69}$ Bruce Kapferer, "Virtuality," in Theorizing Rituals, Volume 1: Issues, Topics, Approaches, Concepts, ed. Jens Kreinath et al., Numen 114 (Leiden: Brill, 2006), 675.

${ }^{70}$ Michael Houseman, "Relationality," in Theorizing Rituals, Volume 1: Issues, Topics, Approaches, Concepts, ed. Jens Kreinath et al., Numen 114 (Leiden: Brill, 2006), 420. 
Nevertheless, the articulation of ritual structure within social reality, insofar as it is actually enacted, is unavoidably a performative process. ${ }^{71}$

Based on the various efforts to define ritual as a performance listed above, we can construct a working definition of ritual performance for the purpose of this study:

Ritual performance is a ritual action whose structure includes a logical object and appeals to culturally postulated superhuman agents, which entails the generation of the concept of the sacred and the sanctification of the conventional order whose function is penetration into human actualities, enactment of exceptional relationships, and emergence of social realities.

Encoded in the definition of ritual are the following terms that will enable us to analyse baptism and communion rituals as phenomena of participation: performance, entailment, agent, social reality, virtuality, and relationality. Ritual participation inevitably entails performance and the social construction of reality. ${ }^{72}$

\subsubsection{Ritual and Text}

Before embarking on the ritual analysis of biblical texts, one must confront the scanty and truncated biblical ritual texts. In fact, Jonathan Z. Smith is on record as holding that biblical data is insufficient to execute a full-scale ritual analysis:

We don't have ritual texts in the bible. We have very poor ethnographic descriptions. You cannot perform a single biblical ritual on the basis of what is given to you in the text. If you can't perform it, then by definition it is not a ritual. The biblical texts are scattered, theoretical reconstructions of what may have happened..$^{73}$

Jonathan Klawans offers a three-point rejoinder. First, by drawing on Jacob Milgrom's "systematic analysis" in his commentaries on Leviticus ${ }^{74}$ that was modelled on the method of filling in gaps, Klawans argues that "one can draw analogies among parallel texts, and suppose that if a certain action is required in ritual A, then perhaps, it is also required in ritual B., 75 Second, employing imagination to fill in a gap in biblical texts is a legitimate tool in performing ritual studies. ${ }^{76}$ This echoes what Frank Gorman has in mind when he writes that "ritual texts seem to demand an imaginative construal of both the rituals depicted and the world within

${ }^{71}$ Edward Schieffelin, "On Failure and Performance: Throwing the Medium Out of the Seance," in The Performance of Healing, ed. Carol Laderman and Marina Roseman (London: Routledge, 1996), 81, 82.

72 See Edward Schieffelin, "Participation," in Theorizing Rituals, Volume 1: Issues, Topics, Approaches, Concepts, ed. Jens Kreinath et al., Numen 114 (Leiden: Brill, 2006), 615-25.

${ }^{73}$ Walter Burkert, René Girard, and Jonathan Z. Smith, Violent Origins, ed. Robert G. Hamerton-Kelly (Stanford: Stanford University Press, 1987), 210, quoted in Jonathan Klawans, Purity, Sacrifice, and the Temple: Symbolism and Supersessionism in the Study of Ancient Judaism (Oxford: Oxford University Press, 2006 ), 52.

${ }^{74}$ Jacob M. Milgrom, Leviticus 1-16: A New Translation with Introduction and Commentary, AB 3 (New York: Doubleday, 1992); Leviticus 17-22: A New Translation with Introduction and Commentary, AB 3a (New York: Doubleday, 2000); Leviticus 23-27: A New Translation with Introduction and Commentary, AB 3b (New York: Doubleday, 2001).

${ }^{75}$ Klawans, Purity, Sacrifice, 52.

${ }^{76}$ Ibid., 52. 
which the rituals take place. An interpretive stance that envisions enactment and imaginatively constructs a ritual world is needed." 77 Third, with regard to ethnography in general, Klawans argues that gap-filling is always necessary to some degree, as no description of any ritual completely records its every minute detail from all perspectives. ${ }^{78}$ Hence, while one should not blithely dismiss the methodological questions that accompany biblical ritual studies, the application of ritual studies methods to biblical texts should not be precluded a priori $^{79}$

We now direct our attention to the question of the relationship between ritual and text. Victor Turner has repeatedly drawn attention to the interrelationship between anthropological ritual studies and literature. In many instances, Turner takes a literary figure and analyses that character based upon his ritual theories. For instance, in Shakespeare's Tempest, Turner associates Gonzalo's fantasy of a commonwealth without laws with his own concepts of communitas and anti-structure and the "I-Thou," a relationship commonly found in the liminal phase of rites of passage ${ }^{80}$ Another example of his more direct application of anthropological concepts onto literature involves Dante's Purgatorio. Placing it in the context of an initiation scenario, Turner analyses Dante's symbols using employing the same categories that he has employed in studies of African rituals: multivocality, a unification of disparate significata, and polarisation. ${ }^{81}$ Against this backdrop of the interrelatedness of ritual and literary opus, Turner comments as follows:

Both rituals and literary works are highly complex semiotic phenomena. Both are systems of multivocal or polysemous signs (symbols)... [Both] are metalanguages, in the former case a nonverbal as well as verbal one, confronting in their symbolisms and within their frames, forms and values that would otherwise be regarded as separate, discrepant, or even opposed. ... Both ... take stock of the cultures in which they are embedded and of which they constitute, so to speak, the reflecting mind and feeling heart. $^{82}$

Such a semiotic approach to the relationship between ritual and texts is taken up by Anders Klostergaard Petersen. Drawing on Rappaport's view of ritual as foundational to the existence and survival of a culture, Petersen proposes that, when religious texts invoke or make reference to ritual experiences, the semantic universe of the texts in question become real to

77 Gorman, "Ritual Studies," 21.

${ }^{78}$ Klawans, Purity, Sacrifice, 52.

79 Scholars who have applied anthropological insights to biblical texts include Mary Douglas, “Atonement in Leviticus," JSQ 1, no. 2 (1993-1994): 109-30, and Frank H. Gorman, The Ideology of Ritual: Space, Time and Status in the Priestly Theology (Sheffield: JSOT Press, 1990).

${ }^{80}$ Edith Turner, "The Literary Roots of Victor Turner's Anthropology," in Victor Turner and the Construction of Cultural Criticism: Between Literature and Anthropology, ed. Kathleen M. Ashley (Bloomington: Indiana University Press, 1990), 163.

${ }^{81}$ Turner, "Literary Roots," 164.

${ }^{82}$ Victor W. Turner, "African Rituals and Western Literature: Is a Comparative Symbology Possible?" in The Literature of Fact: Selected Papers from the English Institute, ed. Angus Fletcher (New York: Columbia University Press, 1976), 77-78. 
the addressees and enhance the persuasiveness of the textual argument. ${ }^{83}$ Petersen's argument hinges on two special types of ritual actions in Rappaport's ritual theory: symbol and index. The symbol refers to the relationship between the sign and the object determined by social convention, whereas the index refers to a material trait by which the sign is physically related to its object. ${ }^{84}$ The collocation of symbolic and indexical elements in ritual helps to overcome the problem of lying and the alternative arising from symbolic communication. ${ }^{85}$ Using Christian communion as an example, Petersen explains that the materiality and immediate accessibility of the bread and wine (as signs) give the sense of an (apparently) real nature to the participants. ${ }^{86}$ The indexical element in the form of genuflection at the altar signifies that "the ritualist indexically acknowledges and embodies an acceptance of the semantic universe in which the communion is embedded." ${ }^{, 87}$ By applying this insight into the relationship between ritual and text, the ritual texts that recall or invoke ritual experience reinforce the addressees' conviction about the "semantic universe instantiated by the text in questions" 88 and, through the indexical nature embedded in ritual, strengthen the rhetorical argument of the text.

Having established the semiotic nature of ritual and text, ${ }^{89}$ we must identify the ritual texts for our inquiry because not all allusions or references to ritual in the biblical canon are suitable for ritual analysis; in certain cases, they are simply too fragmented to be useful for that purpose. Christian Strecker identifies six ways in which ritual and biblical texts are interrelated:

${ }^{83}$ Anders Klostergaard Petersen, "Ritual and Texts," in The Oxford Handbook of Early Christian Ritual, ed. Risto Uro et al. (Oxford: Oxford University Press, 2019), 380, 385.

${ }^{84}$ Petersen, "Ritual and Texts," 376.

85 Ibid., 376-77.

${ }^{86}$ Ibid., 377.

${ }^{87}$ Ibid., 377.

${ }^{88}$ Ibid., 385.

${ }^{89}$ There has been a trend in recent decades amongst anthropologists and theorists to understand ritual in terms of action, performance, and practice rather than structure, semiotics, and symbolic language. The former privileges ritual as a pure action and embodied enactment referring to itself and not to a message that exists independent of proper ritual enactment; see Frits Staal, "The Meaninglessness of Ritual," Numen 26, no. 1 (1979): 9-14; Pierre Bourdieu, The Logic of Practice, trans. Richard Nice (Stanford: Stanford University Press, 1990); and Ronald L. Grimes, "Reinventing Ritual," Soundings 75, no. 1 (1992): 21-41. The latter privileges ritual as a form of symbolic communication that performs or dramatises a social message outside of ritual, and one must break the symbolic code to determine the linguistic message. Proponents of this view include Mary Douglas, Clifford Geertz, Edmund Leach, and Victor Turner; see Geertz, The Interpretation of Cultures. The debate over whether ritual is inherently symbolic will surely continue. However, as Klawans observes, the case for either the self-referential or the symbolic nature of rituals is determined on a case-by-case basis; see Klawans, Purity and Sacrifice, 67-68. For instance, if Staal's interpretation of the Hindu rites as essentially non-symbolic is correct, can we say the same for Christian rituals? The answer is, of course, negative. The essential Christian rituals baptism and communion - were already infused with meaning, significance, and theology when nascent Christ adherents began to perform them; their symbolic messages are derived from the Old Testament, with adjustments in light of the Christ event. Hence, these two schools of thought can actually complement each other and shed light on different aspects of ritual: performance and symbolic messages. 
1. Ein Text enthält Anweisungen zur Ausführung eines Rituals.

2. Ein Text berichtet oder konstatiert den Vollzug eines Rituals.

3. Ein Text beschäftigt sich mit der Bedeutung, Funktion oder rechten Durchführung eines Rituals.

4. Ein Text entstammt direkt rituellem Gebrauch.

5. Ein Text besitzt unmittelbar selbst rituelle Funktion.

6. Ein Text ist mit einem Ritual synekdochisch vernetzt. ${ }^{90}$

We can use these six criteria to identify the ritual texts in the Pauline epistles. The text that includes instructions for carrying out the rite of the Last Supper appears in 1 Cor 11:17-32, and 1 Cor 10:14-22 describes the rite's being carried out. Both Gal 3:26-29 and 1 Cor 12:1314 is concerned with the meaning of baptism in the lives of believers; Eph 4:4-7, Rom 6:1-11, and $\mathrm{Col}$ 2:11-13 echo or allude to the rite of baptism, even though those texts may not be about the rite per se. Thus, the data from all the epistles attributed to Paul will be considered for ritual analysis; since the present study is concerned with the ritual life of Pauline communities, the authorship issue surrounding these epistles is irrelevant.

\subsubsection{Ritual Form}

The analysis of ritual begins with a description of the rite and its enactment:

Ritual studies ... begins with the act of describing the performance events themselves rather than with standards "above," parallels "besides," or heritages "behind" what is seen. ${ }^{91}$

Consonant with this goal, the present study will first establish the ritual elements in the passages under consideration: Rom 6:1-11; Gal 3:27-28; 1 Cor 6:11; 10:1-3, 14-22; 11:17$34 ; 12: 3$. Fully constructing the ritual elements in these passages requires taking into account all possible references and allusions to baptism and the Last Supper elsewhere in the New Testament, for the references to the ritual practices in Paul's epistles are often scant and truncated, as his audiences' familiarity with the rituals obviated much need for fuller descriptions on his part.

An attempt to reconstruct early Christian ritual practice begins with schematic descriptions of the rite in the Gospels, ${ }^{92}$ wherein there is "some degree of continuity between the baptism practiced by John and received by Jesus, and practiced by Christians in the name of Jesus." 93 A determinative factor that triggers the baptism ritual is the divine call to

\footnotetext{
${ }^{90}$ Christian Strecker, Die Liminale Theologie Des Paulus: Zugänge Zur Paulinischen Theologie Aus Kulturanthropologischer Perspektive, FRLANT 185 (Göttingen: Vandenhoeck \& Ruprecht, 1999), 78.

${ }^{91}$ Ronald L. Grimes, Ritual Criticism: Case Studies in Its Practice, Essays on Its Theory, SCR (Columbia, SC: University of South Carolina Press, 1990), 219.

${ }^{92}$ For a more recent discussion on the origins of the Christian baptism ritual, see Hans Dieter Betz, "Jesus' Baptism and the Origins of the Christian Ritual," in Ablution, Initiation, and Baptism: Late Antiquity, Early Judaism, and Early Christianity, ed. David Hellholm et al. (Berlin: De Gruyter, 2011), 377-93.

93 Johnson, Religious Experience, 71.
} 
repentance on the part of an individual or a group. ${ }^{94}$ For instance, on the day of Pentecost, Peter delivers a sermon to a group of pilgrims coming to Jerusalem. After arguing that the scriptures show that the man Jesus of Nazareth is the Messiah foretold in the Old Testament, delivered over by the Jews to be crucified and now raised from the dead, Peter admonishes his audience to "repent and let every one of you be baptized." As the word $\beta \alpha \pi \tau i \zeta \omega$ suggests, baptism is a washing with or full immersion in water. The symbolism with which Paul describes baptism offers some hints as to the specific ritual actions involved. The clothing metaphor used in Galatians in connection with baptism suggests "ritual divestment and reclothing before and after immersion." 95 Furthermore, the language of illumination and enlightenment in Eph 5:14 may allude to the ritual use of lights such as candles. ${ }^{96}$ Finally, the baptismal candidate needs to recite some sort of credo statement about Jesus as the Son of God (cf. Acts 8:37; Eph. 4:5$6)$.

To reconstruct the Christian practice of the Last Supper, ${ }^{97}$ one needs to start from the stories in the gospels of Jesus's presence at meals, as he is the originator of the rite. The meal scene pervades the gospel narrations; during Jesus's ministry, he dines regularly with his opponents at their homes or with his disciples at a table. In his teaching parables, Jesus uses the imagery of meals in connection with the kingdom of God. One highlight of the gospel narratives is the open-air meal that Jesus has with the crowd of thousands, which is made possible by his miraculous multiplication of loaves and fishes (Matt 14:13-21; Mark 6:30-44; Luke 9:10-17). Finally, on the night of his betrayal, he shares a meal with his disciples. The Synoptic Gospel writers' carefully crafted accounts of Jesus taking part in meals suggest “intricate symbolic links between Jesus' presence at a meal, his fellowship with his followers and his authority." 98 The regular practice of communal meals in the early church attests to their significance after Jesus's death. ${ }^{99}$ In 1 Corinthians, Paul provides a glimpse into how the ritual of the Last Supper might be practised in the early church. First, the location where the rite is held is in the private home of certain Christians who are affluent enough to host such a

\footnotetext{
${ }^{94}$ Gerald A. Klingbeil, Bridging the Gap: Ritual and Ritual Texts in the Bible (Winona Lake, IN: Eisenbrauns, 2007), 143.

95 Johnson, Religious Experience, 73.

96 Ibid., 72.

${ }^{97}$ For historical studies of the Lord's Supper, see Hans Lietzmann, Mass and Lord's Supper: A Study in the History of the Liturgy, trans. Dorothea H. G. Reeve, ed. Robert D. Richardson (Leiden: Brill, 1979); J. F. Keating, The Agape and the Eucharist in the Early Church: Studies in the History of the Christian Love-Feasts (1901: repr., New York: AMS Press, 1969); and R. L. Cole, Love-Feasts: A History of the Christian Agape (London: Charles H. Kelly, 1916). For a comparative study of the Lord's Supper, see Jonathan Z. Smith, Drudgery Divine: On the Comparison of Early Christianities and the Religions of Late Antiquity (London: Routledge, 1990).

98 Johnson, Religious Experience, 139.

${ }^{99}$ Cf. Acts $2: 42,46 ; 6: 1-6 ; 20: 7 ; 27: 35$.
} 
gathering. Second, the ritual objects include bread and wine and a cup (Matt 26:26-30; Mark 14:22-26; Luke 22:19-20; 1 Cor 11:23-26), but those objects do not reveal what kind of drink is used in the ritual. The only inkling appears in Jesus's promise at the Last Supper that he would not partake "of this fruit of the grapevine" until the eschatological banquet. Commentators consider this a clear indication that the cup was filled with wine, although there is some dispute over whether fermented wine would have been used. ${ }^{100}$ Finally, the ritual action involves the blessing of the bread and wine and invoking the words spoken by Jesus at the Last Supper: "This is my body which is for you. Do this in remembrance of me" and "this cup is the new covenant in my blood. Do this, as often as you drink it, in remembrance of me." The verbs $\dot{\varepsilon} \sigma \theta \dot{i} \omega$ and $\pi \dot{i} v \omega$ suggest that bread and wine are consumed during the ritual by the participants.

\subsubsection{Ritual Context}

Writing about the analysis of drama as ritual, Grimes provides the next step in proceeding with the analysis of ritual:

At the very least a rituological approach should describe the whole, which extends beyond the plays themselves to the cultural occasion and social circumstances in which they were embedded. ${ }^{101}$

Ritual criticism recontextualises the rites under investigation to consider both the social customs and cultural practices within which a ritual action is performed. Regarding the former, Catherine Bell, in discussing the context of ritual action, introduces several important analytical tools that have been used to define the place of ritual in sociocultural life, two categories of which are relevant to our discussion of baptism and communion in nascent Christianity: system and orthopraxy and orthodoxy. ${ }^{102}$ The first category is how rites relate to one another within a ritual system and how such systems differ from one another by identifying "replicated symbols and gestures that create homologies among different ritual situations." ${ }^{103}$ For example, symbols of birth pervade not only rites to welcome a new-born child but also appear in rites that mark the transition to adulthood. Most societies have more than one ritual system; these systems coexist, sometimes overlapping, sometimes complementing, and sometimes in tension with one another. ${ }^{104}$ We see this tension in two ritual systems at work in the Corinthian community. When writing to the Corinthians, Pauls condemns those who participate in idol worship while

\footnotetext{
${ }^{100}$ See Samuele Bacchiocchi, Wine in the Bible: A Biblical Study on the Use of Alcoholic Beverages (Berrien Springs, MI: Biblical Perspectives, 1989), 156-62.

${ }^{101}$ Grimes, Ritual Criticism, 90.

102 Catherine Bell, Ritual Perspectives and Dimensions (Oxford: Oxford University Press, 1997), 17377, 191-202.

${ }^{103}$ Ibid., 173-74.

104 Ibid., 174.
} 
still partaking of the Last Supper and invokes the dire fate of the Israelites who engaged in idol worship. Thus, according to Paul, participation in pagan worship makes one unfit for participation in the Last Supper; the former is deemed dining at the demons' table. The second category is "to distinguish the degree to which religious traditions put an emphasis either on correct belief in theological doctrines or on correct performance of behavioral responsibilities. ${ }^{105}$ Bell, however, clarifies that the terms orthopraxy and orthodoxy cannot be deployed rigidly and exclusively, as no religious tradition can promote one at the expense of the other: it is inevitably a matter of emphasis. Nevertheless, these terms are still useful for understanding the aspects of ritual density within the life of a religious community. Orthodoxy refers to a religious tradition that seeks to transcend the intertwining of religion, culture, and ethnic identity links, "keep[ing] religious orientation from being subsumed into a particular political-social identity." ${ }^{106}$ We see how concern for orthodoxy plays out when Paul writes on three occasions to different communities regarding the correct understanding of the Christ event, concomitant with a discourse on the baptismal ritual. The discussion of baptism occurs in the discourse of polemic against the Judaizers who insist on the circumcision of the Gentile converts (Gal 3), in the discussion of moral purity and church unity (1 Corinthians), and in response to the possible misunderstanding of God's grace as a licence to sin (Rom 6). In the chapters below, these two analytical tools are used when discussing the social context surrounding baptism and communion rituals.

Regarding the cultural occasions on which Christian rituals are performed, this study will consider initiation rites amongst the Greco-Roman mystery cults, early Jewish ablutions, and sacred meal practices in the Hellenistic world as a common symbolic world in which Christian rituals are situated. Even the first Christian apologists and their pagan adversaries recognised the similarities between pagan and Christian rites of initiation. ${ }^{107}$ The similarities lie in structural parallels: both contain the rituals of cleansing human beings to make them fit for their encounter with the divine. ${ }^{108}$ The pagans cite the similarities as an argument against the uniqueness of Christianity, which Christians rely on to refuse to participate in pagan rituals. The Christians, on the other hand, underscore the revelatory character of their rite by arguing against imitations by demons. ${ }^{109}$ At the beginning of the twentieth century, the history of

105 Ibid., 191.

${ }^{106}$ Ibid., 191.

${ }^{107}$ See Justin, 1 Apol. 62-63; Tertullian, Bapt. 5.1.

${ }^{108}$ Fritz Graf, "Baptism and Graeco-Roman Mystery Cults," in Ablution, Initiation, and Baptism: Late Antiquity, Early Judaism, and Early Christianity, ed. David Hellholm et al. (Berlin: De Gruyter, 2011), 110-11. ${ }^{109}$ Graf, "Baptism," 110. 
religion school introduced the notion that Paul's teaching on Christian initiation was influenced by the beliefs and practices of contemporary mystery cults. ${ }^{110}$ This position has since been repudiated by several scholars, notably Wagner, ${ }^{111}$ whose critique remains influential. ${ }^{112}$ Since Scholars have turned instead to the use of water in Greco-Roman ablutions for the contextual study of baptism. ${ }^{113}$ However, although mystery initiations can no longer justify the modern focus on the provenance of Christian baptism, there is still relevance in a comparative study of mystery initiations and Christian baptism as a religious phenomenon ${ }^{114}$ in the ancient Mediterranean world, as they share a common stock of ideas, themes, and motifs, "offer[ing] to devotees similar experiences, rituals, and ways of salvation and transformation." 115 In addition to Greco-Roman antecedents, we will also consider the evidence concerning the relationship of baptism in early Judaism and nascent Christianity. Most obvious is the practice of proselyte ablution for Gentiles converting to Judaism, followed by circumcision. ${ }^{116}$ There is the baptism of John who extends baptism to the already circumcised Jews, including Jesus (John 3:22; 4:2). Later, in Acts, we see a number of Jews baptised in the name of Jesus and received the Holy Spirit (Acts 1:21-22; 2:38; 9:17-18; 19:1-5). Thus, we could surmise that a

${ }^{110}$ For an earlier discussion, see H. A. A. Kennedy, St. Paul and the Mystery Religions (London: Hodder
\& Stoughton, 1914).
${ }^{111}$ See Günter Wagner, Pauline Baptism and The Pagan Mysteries, trans J. P. Smith (Edinburgh: Oliver \& Boyd, 1967).

112 More recent scholars who have repudiated the notion that the Christian rite of initiation was influenced by its pagan counterparts include Luther H. Martin, "Initiation," in The Oxford Handbook of Early Christian Ritual, ed. Risto Uro et al. (Oxford: Oxford University Press 2019), 348-50, and Graf, "Baptism," 110-14.

${ }^{113}$ See Richard E. DeMaris, The New Testament in its Ritual World (London: Routledge, 2008), 37-56; Richard E. DeMaris, "Water Ritual," in The Oxford Handbook of Early Christian Ritual, ed. Risto Uro et al. (Oxford: Oxford University Press, 2019): 391-405; and Agnes Choi, "Boundary-Crossing in Christian Baptism," in Early Christian Ritual Life, ed. Richard E. DeMaris et al. (London: Routledge, 2017), 75-91.

114 There are four basic approaches to the study of early Christianity in the context of the mysteries. The first is to disregard the Greco-Roman mysteries completely and focus only on Jewish antecedents; see O. Cullmann, Baptism in the New Testament, SBT 1 (London: SCM Press, 1950), 14n2, and G. R. Beasley-Murray, Baptism in the New Testament (London: Macmillan, 1962). The second recognises the pervasiveness of mystery language and practice but refuses to draw conclusions about any possible influence on early Christianity; see B. M. Metzger, "Considerations of Methodology in the Study of the Mystery Religions and Early Christianity," HTR 48 (1955): 1-20, and A. D. Nock, "Hellenistic Mysteries and Christian Sacraments," in Essays on Religion and the Ancient World, ed. Z. Stewart, 2 vols., (Oxford: Clarendon Press, 1972), 809-10. The third is to classify early Christianity under the category of mysteries; see Richard Reitzenstein, Hellenistic Mystery-Religions: Their Basic Ideas and Significance, trans. J. Steely (Pittsburgh: Pickwick Press, 1978). The fourth is to acknowledge that the symbolic worlds of the mysteries and Christianity may have cross-pollinated without demanding a strict causal connection between them and still respecting the distinctiveness of each; see Hugo Rahner, "The Christian Mystery and the Pagan Mysteries," in The Mysteries: Papers from the Eranos Yearbooks, Vol. 2, ed. J. Campbell, Bollingen Series 30 (Princeton: Princeton University Press, 1955), 387-401, and Odo Casel, The Mystery of Christian Worship (Westminster, MD: Newman Press, 1962). The present study takes the fourth approach to discussing the ritual contexts of Christian rituals vis-a-vis mystery religions.

${ }_{115}$ Marvin W. Meyer, "Mystery Religions," in The Anchor Bible Dictionary, vol. 4; ed. David Noel Freedman (New York: Doubleday, 1992), 944.

${ }^{116}$ The source texts are Epictetus, Discourses II, 9, 9-21; Sibylline Oracles 4:62-78; Josephus, A. J. $20: 38-48$. 
single individual could theoretically undergo multiple initiation rites, from Jewish proselyte baptism, circumcision, and the baptism of John to the baptism of Jesus and receiving the gift of the Holy Spirit. ${ }^{117}$ There is another Jewish group contemporary to nascent Christianity whose ablutions are pertinent to our discussion of the cultural context of baptism: the Qumran community, an apocalyptic Jewish sect. Their highly organised community life was structured around high degrees of purity based on the proper knowledge and observance of all the community's regulations and teachings. Amongst various purity observances, ritual washing stands out. Both the scrolls and architecture of the Qumran settlement attest to a heavy emphasis on continuing the practice of ritual immersion to maintain the ritual and moral holiness that was foundational to the group's existence. ${ }^{118}$ These various developments of water rituals in nascent Christianity and early Judaism show that they acted as markers of demarcating and maintaining the group identity from those on the outside. ${ }^{119}$

The cultural phenomenon of sacred meals in the ancient Mediterranean world, whether Greco-Roman or Jewish, has the sense of koinonia, or fellowship, with the deity and with other participants in the meal ritual, which marks off the boundary of the group. ${ }^{120}$ In Greco-Roman practice, the meal was utilised in religious ritual patterning after a banquet. The specific occasion $^{121}$ for such a religious meal varies as it can take place in a sanctuary, at a festival sacrifice, at a religious association gathering, or even at home. ${ }^{122}$ The religious motif of communion with the deity is present at sacrificial meals. Plato, for instance, refers to festival meals as occasions for human beings to find "respite from their troubles" by "associating in their feasts with gods" who are presumably present in the music and wine (Leg. 653D). The presence of a deity at the meal can be manifested in the form of officiator of an entire meal associated with animal sacrifice, as the host, or as the guest at the meal, a role known as theoxenia. ${ }^{123}$ Memory in the Jewish meal, meanwhile, functions as the actualising of a living

117 Johnson, Religious Experience, 98.

${ }^{118}$ See 1QS 3, 4-9; 1QS 5, 13-14; 4QMMT/396.

119 See Sean Freyne, "Jewish Immersion and Christian Baptism: Continuity on the Margins?" in Ablution, Initiation, and Baptism: Late Antiquity, Early Judaism, and Early Christianity, ed. David Hellholm et al. (Berlin: De Gruyter, 2011), 239-46.

${ }^{120}$ See Johnson, Religious Experience, 165-66, and Erin K. Vearncombe, "Rituals for Communal Maintenance," in Early Christian Ritual Life, ed. Richard E. DeMaris et al. (London: Routledge, 2017), 92-112.

${ }^{121}$ Dennis E. Smith, "Meal Customs," in The Anchor Bible Dictionary, vol. 4, ed. David Noel Freedman (New York: Doubleday, 1992), 653-54.

122 The sacrality of meals in domestic settings depends on the role of the goddess Hestia for sacralising the meal itself. See Gunnel Ekroth, "Sacred Meals in Ancient Greece? Dining in Domestic Settings as Compared to Sanctuaries," in The Eucharist-Its Origins and Contexts: Sacred Meal, Communal Meal, Table Fellowship in Late Antiquity, Early Judaism and Early Christianity, Volume III, ed. David Hellholm and Dieter Sanger (Tübingen: Mohr Siebeck, 2017), 1389-1406.

${ }^{123}$ E,g., Pindar, Pyth. 3.93-96; Livy, Ab urbe cond. 29:14.14 
presence in establishing the living God and the people. ${ }^{124}$ Moreover, the prayers of blessing relate to the koinonia of the meal participants with the power of living God, as exemplified in the blessings over the cup in the Passover Haggadah that contains "memory of the past actions of God, (2) actualized in the present company, (3) with hope for the future." 125 The point of contact with the communal meal celebrated by early Christ adherents is that Paul explicitly employs the word koinonia to refer to participation in the Last Supper and at a demons' table. The word koinonia in this context either refers to fellowship with the divine being or to the cultic fellowship between members of a community. ${ }^{126}$

\section{Excursus: The Spiritual Exegesis of Ritual in Mediterranean World}

Besides the general cultural context of rituals of baptism and the Lord's Supper outlined above, we will comment on the spiritual exegesis of rituals in the landscape of Mediterranean philosophical schools and religions. Such a discussion touches on the relationship between ritual and theology, material culture and the intellectual discourse, and the faith (belief) and ritual.

To commence, we need to establish that there is an overlap between philosophy and religion during the so-called post-Hellenistic period ranging from first century BC to second century AD. Within this period the mainstream of philosophical tradition saw an openness towards turning to traditional religion for source of knowledge and authority. Despite the polemics amongst various philosophical schools that hold to conflicting doctrines, they all share the same presuppositions of and approaches to religion. That is, religion is created by wise ancients that reveals the structure of universe and thus contains philosophical knowledge, and the pantheon provides a perfect hierarchical paradigm for all orders on all beings, including human society. ${ }^{127}$ To be sure, one can still find criticisms of religion in the writings of philosophers at this period. For instance, a character named Galaxidorus in Plutarch's On the Daimonion of Socrates denounces the kind of philosopher who relies on divination: "Having

${ }^{124}$ See Joachim Jeremias, The Eucharistic Words of Jesus, 3d ed., trans. Norman Perrin (London: SCM Press, 1966), 244-62; Louis Bouyer, Eucharist: Theology and Spirituality of the Eucharistic Prayer, trans. C. U. Quinn (Notre Dame: University of Notre Dame Press, 1968), 84-90; and W. R. Crockett, Eucharist: Symbol of Transformation (New York: Pueblo Publishing Co., 1989), 9-28.

125 Johnson, Religious Experience, 171n126.

${ }^{126}$ For a recent discussion, see Henk Jan De Jonge, "Koinonia, Koinonoi and Metechein in Paul's Prohibition of Christian Participation in Pagan Cultic Meals (1 Cor 10:14-22)," in Paul-Werk und Wirkung: Festschrift für Abdreas Lindemann zum 70, ed. Paul-Gerard Klumbies and David S. du Toit (Tübingen: Mohr Siebeck, 2013), 58-59.

${ }^{127}$ Peter van Nuffelen, Rethinking the Gods: Philosophical Readings of Religion in the Post-Hellenistic Period (Cambridge: Cambridge University Press, 2011), 4. 
the vocation to teach the whole of the good and the profitable through reason, such a philosophy withdraws from the government of conduct to take refuge with the gods, as if despising reason. ... it resorts to divination and visions seen in dreams, in which the least of men is often no less rewarded with success than the greatest (9.580a)." On the other hand, one could also find a staunch defender of traditional religion among the intellectuals: "I am not a little moved by your authority, Balbus, and by your speech, the peroration of which exhorts me to remember that I am Cotta and a pontiff. That means, I believe, that we have to defend the views about the immortal gods that we have inherited from our ancestors, as well as the rites, ceremonies and observances of religion." 128 Such an ambivalent view towards religion is resolved by the fact that philosophers critically appropriate religion by unpeeling the layers of superstitions that have been heaped on the myth and ritual practices of religion, and thus arriving at the true philosophical knowledge. The presupposition is that the original pure knowledge has been marred by superstition and denigration and therefore the task of philosophers is to restore the true knowledge affected by these two.

The religion of Judeans ${ }^{129}$ and the emerging Christ movement find themselves within this period of intellectual change regarding the tendency of overlapping between philosophy and religion. In defending the rights of Judeans supported by the emperor, Philo of Alexandria mentions that Judeans would receive "ancestral philosophy" ( $\pi \alpha 1 \delta \varepsilon v ́ o v \tau \alpha \iota$ $\left.\varphi \imath \lambda o \sigma o \varphi i^{\alpha} \alpha\right)$ at the gathering on Sabbath day and the religious practices of sacrificial offering $(\theta v \sigma i ́ \alpha \varsigma) .{ }^{130}$ Note that Philo sees the religion of his ancestors in terms of philosophy, accompanied with the ritual practice of sacrifice. The difference between Philo and his Graeco-Roman counterparts lies in the different set of tradition each holds to: the former to the Hebrew Scriptures and in extension Judaism as only truthful tradition whereas the latter to their traditional religions as the external source for ancient wisdom. ${ }^{131}$ Similarly, despite some notable differences, Pauline communities also exhibit traits of philosophical schools with religious practices, including rituals of baptism and the Lord's Supper. Stowers outlines seven common traits shared by Pauline communities and the mainstream philosophical schools: a feature of a distinctive hairesesis (sect) focused on a central value, contra-conventional practices, a dramatic

\footnotetext{
${ }^{128}$ Cicero's On the Nature of the Gods 3.5

129 This study adopts Stanley K. Stowers definition of Judeans who are Jews that are Greeks, Romans, Egyptians. See "Does Pauline Christianity Resemble A Hellenistic Philosophy?" in Redescribing Paul and the Corinthians, ed. Ron Cameron and Merrill P. Miller, ECIL 5 (Atlanta: SBL, 2011), 220.

${ }^{130}$ Philo, Legat. 156: "He knew therefore that they have houses of prayer and meet together in them, particularly on the sacred sabbaths when they receive as a body a training in their ancestral philosophy. He knew too that they collect money for sacred purposes from their first-fruits and send them to Jerusalem by persons who would offer the sacrifices."

${ }^{131}$ van Nuffelen Rethinking the Gods, 22.
} 
reorientation of the self (i.e. conversion), mastery of the body, the founder as a paradigm of virtue, an emphasis on intellectual practices, and the goal and practices that can lead to radical social formations. ${ }^{132}$ Now what concerns us is the relation between the intellectual aspect of Pauline communities vis-à-vis its ritual practices. Since all three traditions-Graeco-Roman, Judeans, and Christ movement — have demonstrated the overlapping of acquiring philosophical knowledge and religious devotions and practices that accompanied them, we will focus on the relation between ritual practices and the intellectual practices (i.e. the spiritual exegesis thereof).

In accordance with the goal of acquiring true knowledge from religion, all three traditions have employed a spiritual exegesis on their respective ritual practices. Plutarch in That Epicurus Actually Makes a Pleasant Life Impossible corrects a superstitious view of gods being a tyrant:

On the other hand the attitude toward God that we find in the ignorant but not greatly wicked majority of mankind contains no doubt along with the sense of reverence and honour an element of tremulous fear (and from this we get our term for superstition); but outweighing this a thousand times is the element of cheerful hope, of exultant joy, and whether in prayer or in thanksgiving of ascribing every furtherance of felicity to the gods. This is proved by the strongest kind of evidence: no visit delights us more than a visit to a temple; no occasion than a holy day; no act or spectacle than what we see and what we do ourselves in matters that involve the gods, whether we celebrate a ritual or take part in a choral dance or attend a sacrifice or ceremony of initiation. For on these occasions our mind is not plunged in anxiety or cowed and depressed... No, wherever it believes and conceives most firmly that the god is present, there more than anywhere else it puts away all feelings of pain, of fear and of worry, and gives itself up so far to pleasure that it indulges in a playful and merry inebriation. (1101 E)

Attributing the god as a vengeful and wrathful divine being that needs to be appeased with is a superstition accretion heaped on the religion. Plutarch interprets or cites ritual practices such as visiting a temple, offering a sacrifice, and the observance of a holy day as evidence that on these occasions the participants come contact with the god and share the joy of religious festivities with the divine. The gods have no need of foods and drinks offered to them (Lucian, De Sacrificiis 9). Rather, ritual ceremony is an occasion of enjoying fellowship with gods by inviting them to a meal on the table. ${ }^{133}$ Although the mind can perceive the present of God everywhere if it believes so, only on the occasion of communal religious celebration one can fully experience that joy. Philo employs spiritual exegesis on the feasts and the rite of circumcision of the Jews to gain deeper meaning shown in these symbolic acts:

132 Stowers, "Pauline Christianity," 229-36.

${ }^{133}$ This is a concept of theoxeny, giving hospitality to gods; see Livy, Urb. Cond. 5.13.6-8 
It is true also that the Feast is a symbol of gladness of soul and of thankfulness to God, ... It is true that receiving circumcision does indeed portray the excision of pleasure and all passions, and the putting away of the impious conceit, under which the mind supposed that it was capable of begetting by its own power: ..., if we are going to pay heed to nothing except what is shewn us by the inner meaning of things. ${ }^{134}$

This passage evinces Philo approach to interpretation of ritual in general. The basic premise is that all material objects in ritual performance is a symbolic representation of higher realities that lie underneath them. ${ }^{135}$ Thus, ritual actions are conceptualised, assigning certain meanings to each act. In this case, the rite of circumcision symbolically refers to the purgation of all bodily passions. The mind ( $\delta 1 \alpha$ oror $\alpha$ ), which sometimes is equated with the soul ( $\psi v \chi \eta ์)$, a higher and truer human faculty, in Philo's writings remains a focal point of spiritual cultivation, since it identifies with the image of God, the Word ( $\lambda$ óyos), through whom the world is fashioned (Spec. Laws 1.81). Therefore, the cultivation of that which is Godlike in human faculty means a restoration of communion between humanity and God. Circumcision, then, serves as a mean to remove obstacles that hinder this divine-human communion, both externally and internally. Finally, Paul in his letter to the Romans gives a spiritual reading of sacrificial offering with a view to admonish his audience to moral and spiritual cultivation:

I appeal to you therefore, brothers and sisters, by the mercies of God, to present your bodies as a living sacrifice, holy and acceptable to God, which is your spiritual worship. Do not be conformed to this world, but be transformed by the renewing of your minds, so that you may discern what is the will of God—what is good and acceptable and perfect (Rom 12:1-2).

Paul here indicates that the worship of God needs to be informed by rational worship ( $\lambda \alpha \tau \rho \varepsilon i ́ \alpha)$, which relates to the mind. The mind needs to be properly cultivated through dispositional re-orientation from the values of this world to that which is pleased to God, entailing mediation on the positive values and the cultivation of virtues (Phil 4:8, 2 Cor 4:16, cf. Eph 4:23, Col 3:2). By extension, this intimates a whole range of activities related to the intellect or mind, including speaking, writing, teaching (transmission), and textual interpretation. ${ }^{136}$ Indeed, these intellectual activities serve as a bedrock for the existence of Pauline communities: Paul's esoteric knowledge of Christ, his textual interpretive skill that cements the identity of Galatian communities as children of Abraham, and his preaching of the gospel of Christ.

${ }^{134}$ Abr. 92

135 William K. Gilders, “Jewish Sacrifice: Its Nature and Function (according to Philo).” In Ancient Mediterranean Sacrifice, ed. Jennifer Wright Knust and Zsuzsanna Varhelyi (Cary: Oxford University Press, 2011),97-8.

136 Stowers, "Pauline Christianity," 234. 
Several observations can be offered from the discussion of spiritual exegesis in all three traditions. First, the focus on the mind or soul's cultivation occupies an important place in the doctrines and practices of these traditions. Second, the external rites and rituals serve as a symbolic representation by which one delves deeper into the deeper realities represented by ritual actions. For Graeco-Roman philosophers, their ancestral religion contains wisdom of the ancients that need to be re-discovered; for Judeans, specifically Philo, the rites of Jewish people hide a higher knowledge about the soul; for Paul, the meal ritual recalls Christ myth, the founding story of Christ group. Third, the spiritual exegesis salvages religion from the accretions of superstition that have heaped on it over the centuries. Paul shares the same sentiment of Graeco-Roman intellectuals that the decline of Roman religion is a result of worshiping human-made images. Employing a Varronian view on the denigration of Roman religion, Paul states "the transition from aniconic cult to the worship of images"137 in Romans 1:23: "and they exchanged the glory of the immortal God for images resembling a mortal human being or birds or four-footed animals or reptiles." As a result, such worship distorts the mind and undermines its faculty to perceive God who is invisible (Plutarch, Numa 8.7-8; Rom 1:25). Thus, a logical form worship should replace carnal worship by the transformation of the mind, which includes the task of spiritual exegesis of rituals.

Lastly, despite the intellectual endeavour of interpreting rituals in a critical manner, rituals remain an intrinsic praxis of in all three traditions. Epicureans, for instance, developed their own system of liturgical celebrations including the annual celebration of Epicurus's birthday, monthly commemoration of Metrodorous, and other festive days. ${ }^{138}$ Philo writes that the observance of the Jewish laws, including rites and rituals, helps one grasp the inner meaning contained therein (Migration of Abraham 93). He makes an analogy that just as body is an abode for the soul the external rites embody higher knowledge (92-93). Paul indicates the significance role the rituals of baptism and the Lord's Supper play in his letters: the former facilitates a formation of new social identity in ekklesia by altering the candidate's orientation of the self (1 Cor 12:13; Gal 3:27-28); the latter realises the central ethos of Christ movement, that is, self-sacrificing love towards others shown in the fellowship of meal ritual. In conclusion, the intellectual aspect of three traditions are closely connected with their respective physical praxis of rituals; one cannot dismiss rituals without doing justice to their philosophical

${ }^{137}$ G.H van Kooten, "Pagan and Jewish Monotheism According to Varro, Plutarch and St Paul: The Aniconic, Monotheistic Beginnings of Rome's Pagan Cult - Romans 1.19-25 in a Roman Context." In Flores Florentino, 122:633-651. Martinus Nijhoff/Brill, 2007), 648.

138 Richard Allen Wright, "Christians, Epicureans, and the Critique of Greco-Roman Religion" (ProQuest Dissertations Publishing, 1994), 84. 
(theological) discourses and vice versa. This discussion of spiritual exegesis of rituals in Mediterranean milieu will help situate the discussion of relation between pistis and ritual in chapter four in a culturally and historically informed context.

\subsubsection{Models and Theories from Ritual Studies}

The final step in the analysis of ritual is the employment models or theories developed in the fieldwork of anthropologists or social scientists regarding ritual practices across religious traditions and communities. The practitioners of social-scientific criticism employ models in their work. Philip F. Esler defines a model as a "distinctive approach to the integration of the social sciences and biblical interpretation characterised by very explicit use of theory and the comparative method". ${ }^{139}$ Bruce Malina characterises a model in general terms as "an abstract simplified representation of some real-world object, event, or interaction constructed for the purpose of understanding, control or prediction." ${ }^{140}$ T. F. Carney delineates theory from model as follows:

\footnotetext{
A theory is based on axiomatic laws and states general principles. It is a basic proposition through which a variety of observations or statements become explicable. A model, by way of contrast, acts as a link between theories and observations. A model will employ one or more theories to provide a simplified (or an experimental or a generalized or an explanatory) framework which can be brought to bear on some pertinent data. ${ }^{141}$
}

Models help reveal the values and perspectives of the interpreter and the text under investigation. ${ }^{142}$ Social models are "cognitive maps" that organize patterns of social behaviours, social grouping, and processes of social interaction, to name a few. ${ }^{143}$ Models do not generate evidence but are a means "for envisioning relationships and patterns among the evidence."144 Beyond their cognitive value, models serve as a heuristic tool that allows comparisons to be made with the text in order to pose a new set of questions that will "prompt the search for [new]

\footnotetext{
(1998): 254.

${ }^{140}$ Bruce J. Malina, “The Social Sciences and Biblical Interpretation,” Interpretation 36, no. 3 (July 1982): 229-42.

${ }^{141}$ T. F. Carney, The Shape of the Past: Models and Antiquity (Lawrence, KS: Coronado Press, 1975), 8.

142 Philip F. Esler, The First Christians in their Social World: Social-Scientific Approach to New Testament Interpretation (London: Routledge, 1994), 12-13.

${ }^{143}$ Elliott, Social-Scientific Criticism, 43.

144 Ibid., 43.
}

${ }^{139}$ Philip F. Esler, review of D. G. Horrell, The Social Ethos of the Corinthian Correspondence, JTS 49 
patterns, correlations, and coherency among masses of materials." ${ }^{145}$ Again, the text, not the models, must supply the answer.

Social scientists use two types of model in biblical exegesis: environmental models and cross-cultural models. The former is developed from existing data in the biblical environment without "import[ing] from outside the social and cultural milieu of text concern." 146 This is exemplified by W. Meeks's The First Urban Christians: The Social World of the Apostle Paul, the aim of which is to understand the formation of the ekklesia in the time of Paul by developing a model of group formation based solely on the materials available in Paul's writings. The latter models are drawn from the field of social sciences and are developed by empirical research on human behaviours. The underlying assumption is that certain human behaviours have been shared and maintained through the centuries by any number of societies, regardless of time or place. The social sciences have objectified and formulated these patterns into theories and models by means that can be tested using any number of societal groups. In this thesis, crosscultural models are adopted as a theoretical framework that is informed by the Jewish and Greco-Roman environments in the course of comparative analysis.

Some exegetes have criticised the use of models in biblical exegesis, citing "the imposition of alien and inappropriate frameworks on first-century data." 147 To this objection, users of models respond that any modern interpreter investigating the biblical text will inevitably bring their own presuppositions - and thus a model - to the text; there is no neutral reading of the text. The relationship between reader and text is dialectical, with both text and reader bringing something to the interpretive process. Thus, the question of whether one should use a model should be reframed in terms of whether the model chosen is useful in providing answers that are historically plausible. If the answer is in the affirmative, the project has been successful. If not, the interpreter should find another suitable model that will yield insights into the historical and social dimensions of the text that have been buried under the weight of history.

The theories selected for the analysis of baptism and the Last Supper fall within the ritual classification of rite of passage and rite of communion or exchange. ${ }^{148}$ One question

\footnotetext{
145 Ibid., 44; Esler, The First Christians, 13.

${ }^{146}$ Elliott, Social-Scientific Criticism, 43.

${ }^{147}$ Philip F. Esler, ed., Modelling Early Christianity: Social-Scientific Studies of the New Testament in Its Context (London: Routledge, 1995), 4.

148 The present study adopts Catherine Bell's ritual classification to treat baptism as a rite of passage and the Last Supper as a rite of communion, all the while acknowledging that these categories are scholarly constructs and that a ritual can sometimes be categorised differently depending on the context in which it occurs; see Grimes, Craft of Ritual Studies, 199-207. For further discussion of the modern study of the classification of rituals, see Lauri Honko, "Theories Concerning the Ritual Process: An Orientation," in Science of Religion: Studies in
} 
naturally arises: Can these two rites in nascent Christianity be classified under the modern categories of rite of initiation and rite of communion? A consideration of the classification of these rites will affect how one understands the ritual functions of these rites.

Regarding ritual baptism, Meeks, while adopting van Gennep's tripartite model of rite of passage - pre-liminal state, liminal state, and post-liminal state - finds it best to rearrange Pauline baptismal themes into opposing pairs: death and life, burial and enthronement, taking off and putting on, and so on. DeMaris, however, finds Meeks's analysis lacking in the last stage of the model, the language of incorporation, to which DeMaris acknowledges that some liminal elements such as "nudity, symbolic of death and rebirth as a child" can be placed on the "reaggregation side." ${ }^{149}$ DeMaris casts doubt on whether it is legitimate to see ancient Roman society as the kind of complex society in which ancient Christians remained marginal or liminal over an extended period of time. Although Turner had in mind beatniks and hippies in twentieth-century American society when he expanded on the concept of liminality, Christians in ancient Roman society were deemed a marginal sect within Judaism whose peculiar doctrine was the worshipping of a recently executed, self-proclaimed messiah. After the destruction of the temple in Jerusalem in AD 70, Christians emerge as a distinct group separate from mainstream Judaism, which exacerbated the marginal status of the Christian community as a novel religion coming on the scene. Thus, ancient Roman society does qualify as the kind of complex society Turner had in mind when speaking of a group identity remaining indefinitely in a liminal state. Second, Meeks observes that the Pauline language of dying and rising does not refer exclusively to the baptismal rite (2 Cor 4:10-11; Gal 2:19-20; Phil 3:1011). Moreover, the post-baptism language in Paul sometimes does not follow the movement from death to life but is a metaphor for death (cf. 2 Cor 6:8-9). For this reason, Meeks poses the question, "Is dying-rising language best understood sequentially, as steps in the initiation process, or existentially, as an expression of the believer's post-baptism life in Christ?"150 Rather than trying to wrench these two conflicting usages of dying-rising language in the Pauline writings into a coherence or harmony that cannot be intellectually legitimate, one must simply acknowledge that Paul is not a systematic theologian paying careful attention to consistent use of theological language when he addresses different pastoral issues arising in different congregations; rather, he subtly altered his use of the same language to appeal to a

Methodology, ed. Lauri Honko, Religion and Reason 13 (The Hague: Mouton 1979), 369-90, and Jens Peter Schjodt, "Initiation and the Classification of Rituals," Temenos 22 (1986): 93-108.

${ }^{149}$ DeMaris, New Testament in its Ritual World, 19.

${ }^{150}$ Ibid., 19. 
particular community with a specific background. Perhaps Paul did not see the tension of these seemly contradictory uses of dying-raising language because, in the special moment of baptism, the believer experiences the full redemptive story of the death and resurrection of Christ synchronically, whereas life after baptism still needs to fully actualise the dying-rising narrative diachronically. Thus, although DeMaris is correct to identify the inconsistent application of van Gennep's tripartite model of rite of passage in Meeks's work, that inconsistency does not necessarily invalidate the classification of baptism as a rite of passage. ${ }^{151}$

The classification of the Last Supper as a rite of communion or exchange is more straightforward than the baptism situation, since Jesus, who instituted the rite on the night he was betrayed, patterned it after the paschal meal, replacing the sacrificial lamb with bread and wine signifying his body and blood. Paul also speaks of partaking of bread and wine at the Last Supper as communion in Christ's body and blood as opposed to participating in a demons' banquet (1 Cor 10). Inherent in the communal rite is the concept of sacrifice as a distinct form of divine-human interaction implicated in "a union of the human and divine worlds: the offerer, the recipient, and the offering itself are understood to become together in some way, however briefly. The purpose of this form of cosmic union is usually explained as a matter of renewing the universe and reordering the human-divine relations that sustain it." ${ }^{152}$ A proper understanding of the nature of the offering or sacrifice involves "three distinctive participating entities": the one who initiates the exchange, the one that is given, sacrificed, or offered, and the one that receives the gifts. ${ }^{153}$ A number of theories and models attempt to explain each of these phenomena as signifying various aspects of divine-human interaction and social organisation. ${ }^{154}$ The sacrificial nature of the Last Supper is conspicuous from nascent

151 The literature on rites of passage is vast. These are some of the most important contributions: Arnold van Gennep, The Rites of Passage, trans. Monika B. Vizedom and Gabrielle L. Caffee (London: Routledge \& Kegan Paul, 1960); Mircea Eliade, Rites and Symbols of Initiations: The Mysteries of Birth and Rebirth (New York: Putnam, 1958); Victor Turner, The Ritual Process: Structure and Anti-Structure (Chicago: Aldine, 1969); Mary Douglas, Purity and Danger: An Analysis of Concepts of Pollution and Taboo (London: Routledge, 2008); and Martha Fried and Morton Fried, Transitions: Four Rituals in Eight Cultures (New York: W. W. Norton, 1980).

152 Bell, Ritual Perspectives and Dimensions, 112.

${ }^{153}$ Understanding Religious Sacrifice: A Reader, ed. Jeffrey Carter (London: Continuum, 2006), 4.

${ }^{154}$ For sacrifice as gift, see E. B. Tylor, Primitive Culture: Researches into the Development of Mythology, Philosophy, Religion, 2 vols., repr. (Peter Smith: Gloucester, MA: 1970). For sacrifice as a communal meal, see W. Robertson Smith, Lectures on the Religion of the Semites: The Fundamental Institutions, 3d ed., repr. (New York: Ktav Publishing House, 1969). For the link between the profane and sacral worlds, see Henri Hubert and Marcel Mauss, Sacrifice: Its Nature and Function, trans. W. D. Halls (London: Cohen \& West, 1964). For sacrifice as magic, Gerardus van der Leeuw, "Die do-ut-des-Formel in der Opfertheorie," AR 20 (1920-1921): 241-53. For sacrifice as re-enactment of primordial event, see Adolf E. Jense, Myth and Cult among Primitive Peoples, trans. Marianna Tax Choldin and Wolfgang Weissleder (Chicago: University of Chicago Press, 1973). For sacrifice as an anxiety reaction, see Vittorio Lanternari, "La Grande Festa": Vita ritual e sistemi di produzione nelle societa tradizionali, 2d ed. (Bari: Edizioni Dedalo, 2004). For sacrifice as a mechanism for diverting violence, see René Girard, Violence and the Sacred, trans. Patrick Gregory (London: Bloomsbury Academic, 2017). 
Christianity against the backdrop of Hellenised Judaism that has undergone an evolution of spiritualisation of the understanding of sacrifice ${ }^{155}$ "stem[ming] from the exile experience and the prophetic opposition to formalistic rituals." ${ }^{156}$ Remaining in the same trajectory of the spiritualisation of sacrifice, ${ }^{157}$ early Christ adherents connected the institution of the Last Supper with the new covenant foretold by Jeremiah, especially the Lukan and Pauline accounts of the meal that juxtapose blood with the covenant (see Matt 26:28; Mark 14:24; Luke 22:20; 1 Cor 11:25; cf. Jer 31:31-33). ${ }^{158}$ Furthermore, the following symbols of the Last Supper are frequently understood as sacrificial in nature: flesh and blood imagery has a certain sacrificial nature; ${ }^{159}$ Jesus's act of giving the bread and wine may draw from the sacrificial traditions of giving; ${ }^{160}$ and the "for you" (Luke 22:19, 20; 1 Cor 11:24) and "for many" (Matt 26:28; Mark 14:24) phrasing may have expiatory connotations. ${ }^{161}$ Therefore, using theories on sacrifice is suitable for analysing the Last Supper in nascent Christianity.

Finally, a remark on the use of multiple theories in this study is in order. Given the broad concept and definition of theory and ritual, the contemporary scholarship on ritual study sees a theory-consumption phenomenon varying in scholarly styles from a vigorous test of a single theory to cherry-picking multiple theories. Grime diagnoses this eclectic approach to ritual study in the contemporary scholarship:

They rarely utilize and test a single theory, much less invent one; rather, they cherry-pick multiple theories. Searching for trenchant, supportive quotations, they cite this writer and that (Clifford Geertz, Victor Turner, Harvey Whitehouse, and Roy Rappaport), opt for some of the well-known pairs (Thomas Lawson and Robert McCauley or Caroline Humphrey and James Laidlaw), or select a school of thought (symbolic anthropology, biogenetic structuralism, or, cognitive anthropology). ${ }^{162}$

${ }^{155}$ Philo of Alexandria praises thanksgiving prayer as the highest form of sacrifice. See D. Power, The Eucharistic Mystery: Revitalizing the Tradition (New York: Crossroad, 1994), 56, 114; Robert J. Daly, The Origins of the Christian Doctrine of Sacrifice (London: Darton, Longman \& Todd, 1978), 22, 28, 44, 85, 96, 132, and 134; and L. M. Chauvet, Symbol and Sacrament: A Sacramental Reinterpretation of Christian Existence, trans. P. Madigan and M. Beaumont (Collegeville. MD: The Liturgical Press, 1995), 241-44.

156 John H. McKenna, "Eucharist and Sacrifice: An Overview,” Worship 76, no. 5 (2002): 387.

${ }^{157}$ Mary Douglas, in her analysis of Leviticus, has demonstrated that there is no sudden rupture between the Christian doctrine of the Eucharist and cereal sacrifice. She supports her thesis with three arguments: 1) the priestly editors of Leviticus evince an attitude towards animal life that is respectful and protective; 2) there was already a full-blown system of cereal sacrifice alongside the animal sacrifice in Leviticus; and 3) given these two points, it would not have been a great challenge to institute a vegetable sacrifice, coupled with the long tradition of seeing the body as a microcosm of the universe and God's temple and the "interchangeability in the Bible of words for spiritual and material food, bread and flesh, wine, blood, life and soul"; see Mary Douglas, "The Eucharist: Its Continuity with the Bread Sacrifice of Leviticus," Modern Theology 15, no. 2 (1999): $209-24$.

${ }^{158}$ McKenna, "Eucharist and Sacrifice," 388-89.

${ }^{159}$ Bruce Chilton, A Feast of Meanings: Eucharistic Theologies from Jesus through Johannine Circles (Leiden: Brill, 1994), 66-74; Jeremias, Eucharistic Words, 220-25; Xavier Léon-Dufour, Sharing the Eucharistic Bread: The Witness of the New Testament (New York: Paulist Press, 1987), 117-56.

160 Jeremias, Eucharistic Words, 231-37; Chilton, Feast of Meanings, 73.

${ }^{161}$ Chilton, Feast of Meanings, 71-72; Jeremias, Eucharistic Words, 225-31.

162 Grimes, Craft of Ritual Studies, 170. 
Theoretical pluralism, however, is not synonymous with cherry-picking. In his Ritual and Christian Beginnings, Risto Uro delineates three advantages afforded by the theoretical pluralism approach. ${ }^{163}$ First, citing cognitive science of religion (CSR) as an example, Uro observes that since CSR is a diverse and complex movement originating from different theories and theoretical backgrounds, limiting oneself to a particular theory would not allow biblical scholars to assess the limits of a particular theory and the extent to which the theory used for analysis is appropriate. Second, using target-specific theories over all-embracing theories has the advantage of specifically defined explanatory mechanisms that the all-embracing theories lack due to their focus on sweeping topics and themes. Third, a specific subject of study is subject to a specific definition of ritual and the term ritual, like religion, is a "fuzzy set" or "family-resemblance" concept that defies an all-embracing definition. Given the fluidity of the definition of ritual, working with different theoretical perspectives to identify "rituals" may be the best strategy for investigating early Christian practices because the meagre sources do not allow for a vigorous test of a single theory. Despite these advantages of theoretical pluralism, Uro does sound a word of caution against the 'hyper-pluralistic' position that is drowned in a sea of relativism and persistently pessimistic about the possibility of gaining knowledge of the world.

This study takes the same approach as Uro in investigating the two cardinal ritual practices of nascent Christianity: baptism and the Last Supper. The use of multiple theories in this study can be likened to a Matryoshka doll, in which ever smaller figures are nested inside one another. The outer and thus largest figure is the concept of participation, the overarching theoretical framework. The next size down represents the ritual categories into which baptism and the Last Supper fall; that is, the rite of passage and the rite of communion. The smaller second smallest figure is equivalent to the various ritual theories selected for the two ritual categories, and the smallest is connected to recent "middle-range" ritual theories from different schools of thought that complement the all-embracing theories that have been selected.

\subsection{Thesis Statement}

It is argued that the Christian rituals of baptism and the Last Supper affect union with Christ by transforming believers into a new existential status, incorporating them into the body of Christ, and participating in the salvation event of Christ's death and resurrection. There is a close connection in Pauline thought between the sacraments and union with Christ. When Paul

${ }^{163}$ Risto Uro, Ritual and Christian Beginnings: A Socio-Cognitive Analysis (Oxford: Oxford University Press, 2016), 62-64. 
speaks of being baptised into Christ's death, he is referring to baptism as a means through which believers participate in Christ's salvific events. In 1 Cor 11, when Paul quotes Jesus's statement that the bread and wine are his body and blood, Paul is referring to communion with Christ, to sharing in his life. While it has been argued that faith rather than ritual unites believers with Christ, faith and rituals are both necessary elements in the process of participation in Christ. Faith is the interior reality through which believers place their confidence in the redemption Christ won on the cross, whereas rituals are the outward manifestation of that inward reality and the physical means by which one achieves real fellowship with Christ. By using theories of ritual about the rite of passage and sacrifice to study baptism and the Last Supper, this study demonstrates that rituals and sacraments are closely connected with the union with Christ in the sense that religious rituals mediate between the world of physical experience and the world of metaphysical imagination.

\subsection{Conclusion}

In this study of the contribution that rituals make to our understanding of Paul's notion of union with Christ, we have chosen to address the question through ritual analysis, so that we may see the key Pauline passages in a new light. Accordingly, the thesis is divided into two parts. In Part 1, we use a ritual transformation model to analyse baptismal and eucharistic passages in the undisputed letters of Paul. In part 2, we move beyond the ritual model application to exegetical issues relating to Paul's "in Christ" language: how baptism and the Lord's Supper relate to the notion of union with Christ and the relation between faith and ritual. We then conclude the thesis with an assessment of how analysing the rituals of baptism and the Last Supper deepens our understanding of the ritual dimension of participation in Christ in Pauline thought. 


\section{Chapter 2 \\ Baptism as a Ritual Performance}

\subsection{Introduction}

The central question considered in this chapter is how the baptism ritual facilitates union with Christ. To that end, we first need to establish a set of baptismal passages in Paul's writings to be used for analysis. Then, we need to reconstruct the entire baptism ritual ceremony to examine its ritual functions before placing the baptism performance in its wider social and cultural context. Finally, we commence the ritual analysis of baptism ritual using the performance approach, highlighting how each element in the ritual performance contributes to the overall transformative experience with the divine. The aim of this chapter is to demonstrate that the baptismal passages that Paul alludes to in his writings are denotative of the ritual background and thus each passage, with its theological interpretation and motifs, contributes to the understanding of the transformative experience with the divine and the reconfiguration of human reality made possible through the enactment of the ritual performance.

\subsection{Ritual Text}

Of all the baptismal ${ }^{164}$ passages in Paul's writings, none offers a direct report of the execution of the rite or contains instructions or commands for carrying out the rite. Christian Strecker identifies six ways in which ritual and text are interwoven, echo, allude to, or refer to the rite in Paul's letters on the topic. ${ }^{165}$ In this section, we demonstrate that the baptismal allusions in Paul's corpus (1 Cor 6:11; 12:13; Gal 3:27-28; Rom 6:1-11) have ritual denotations or backgrounds by providing three lines of evidence: the baptism tradition, the performative indicators, and metaphor predication. The first line of evidence supporting the baptismal traditions behind these passages has drawn some criticism that favours reading the baptismal passages as integral parts of Paul's writings, rendering form or source analysis irrelevant. To bolster the argument that these passages are indeed ritual denotations, we enlist help from anthropology, where recent scholarship on ritual studies has shed light on the performative aspect of ritual and the function of metaphor in rituals. We argue that these two indicators can

${ }^{164}$ In classical literature, the term $\beta \alpha \pi \tau i \zeta \omega$ generally means to dip, plunge, drown, or drench. In the New Testament, the term has been taken to refer to various types of ablution. Thus, Bauer and Danker offer the following definitions: (i) "to wash ceremonially for purpose of purification, wash, purify"; (ii) "to use water in a rite for the purpose of renewing or establishing a relationship w. God, plunge, dip, wash, baptize"; and (iii) "to cause someone to have an extraordinary experience akin to an initiatory water-rite"; see William Arndt, Frederick W. Danker, and Walter Bauer, A Greek-English Lexicon of the New Testament and Other Early Christian Literature, 3d ed. (Chicago: University of Chicago Press, 2000), 164.

165 Christian Strecker, Die liminale Theologie, 78. 
be detected in Paul's writings, supplying further evidence for the ritual background contained therein.

The baptismal allusions in Paul's corpus have been recognised as belonging to an earlier pre-Pauline tradition with which Paul is working. ${ }^{166}$ The arguments for pre-Pauline origins of these passages are the sudden switch of personal pronouns signifying a break in the flow of the passage, the highly exalted and poetic religious language, and the same set of phrases occurring several times throughout the Pauline corpus. Employing form analysis, scholars have isolated and classified various forms of baptismal formulae in these passages. Arguing that the inclusion

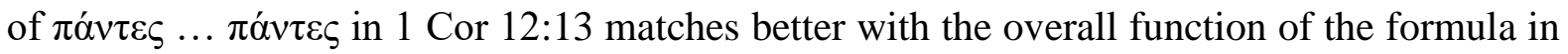
the immediate context of Paul addressing the baptised members of the Christ assembly, Hellholm calls this tradition an inclusive formula. ${ }^{167}$ The form of the tradition found in 1 Cor 6:11 has been classified as a justification formula in a Hellenistic-Jewish Christian context, when a newly baptised neophyte was pronounced justified coram Deo. ${ }^{168}$ This classification fits well with the intentions of Paul, who is reminding the Corinthians of their pagan life vis-àvis the life after baptism (a then-now schema), and the turns of phrase that culminate in

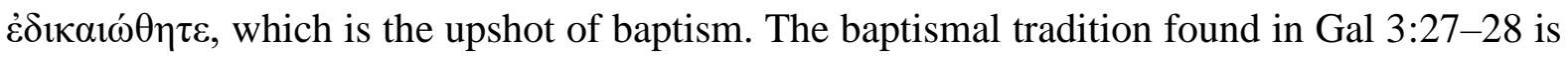
aptly classified as a clothing formula rather than a beatitude, as Betz has proposed. The setting of the formula is employed in the baptismal liturgy, where it is proclaimed after the candidates

${ }^{166}$ Granted, some scholar shows scepticism towards any alleged pre-Pauline tradition behind these baptismal texts, citing that there is no evidence beyond Pauline texts. For instance, one might cite the formulation in Rom 6:7 that "For whoever has died is freed from sin" is nowhere can be found in other biblical texts or the

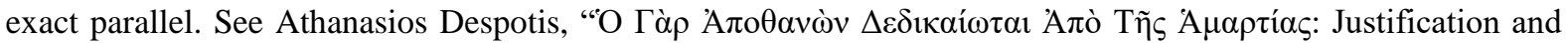
Conversion from the Perspective of Rom 6:7." In Participation, Justification, and Conversion: Eastern Orthodox Interpretation of Paul and the Debate Between "Old and New Perspectives on Paul", edited by Athanasios Despotis. WUNT II 442 (Tübingen: Mohr Siebeck. 2017) 29-57. However, in this instance the core baptismal text is found Rom 6:3-4, and the ensuing statements are Paul's application of baptismal ritual in this context for his rhetorical purpose. In fact, the triple pairs formula in Gal 3:28 (Jew/Greek, slave/free, male/female) can be found in other early Christian writings. Undoubtedly, one could make an argument for ritual background behind these texts without resorting to source or form criticism by acknowledging that behind these baptismal rhetoric lies an allusion to the ritual. However, it seems that the argument would be weaker compared to the one made based on pre-Pauline tradition, since it would fail to distinguish the exact form of ritual in question as it all appears to be a rhetorical device. Now, if we advance the argument through the careful analysis of the textual form, we can delineate the form of ritual insofar as available information is presented in the text. Finally, one can view these baptismal texts as both containing baptismal tradition and a rhetorical tool bolstering Paul's argument, for Paul has integrated them into his overall arguments throughout his letters.

167 David Hellholm, "Vorgeformte Tauftraditionen und deren Benutzung in den Paulusbriefen," in Ablution, Initiation, and Baptism: Late Antiquity, Early Judaism, and Early Christianity (ed. David Hellholm et al.; Berlin: De Gruyter, 2011), 429.

${ }^{168}$ F. W. Horn, Das Angeld des Geistes: Studien zur paulinischen Pneumatologie, (FRLANT 154; Göttingen: Vandenhoeck \& Ruprecht, 1992), 144, 257; U. Schnelle, Gerechtigkeit und Christusgegenwart. Vorpaulinische und paulinische Tauftheologie, GTA 24, 2d ed. (Göttingen: Vandenhoeck \& Ruprecht, 1983$), 42$. 
have been baptised. Finally, Rom 6:1-11 contains a form of baptismal tradition that has been identified as an identification formula. ${ }^{169}$

The performative indicators of a ritual include the speech act, the ritual action, and the role of the human body in the efficacy of performatives and the establishment of social order. Over the last few decades, philosophers have recognised the performative as a distinct characteristic of human speech, describing its examples as "performative utterances" (J. L. Austin) and (J. R. Searle ) "illocutionary acts." ${ }^{170}$ The peculiarity of the performative utterance lies in the generative and creative quality of the speech act. Rather than reporting a statement that corresponds to reality, the speech act itself creates a status whose truthfulness hinges on the nature of the utterance itself. ${ }^{171}$ Thus, utterances transform a young boy into a man, a couple into a husband and wife, and a prince into a king, because they are deemed true according to the ritualised utterances. ${ }^{172}$ The notion of ritual action has been understood in two different sometimes antithetical - ways. One body of ritual theory understands action as an individual or group agency, while the other sees it as a purely formal set or sequence of actions. ${ }^{173}$ The former concerns matters of agency, embodiment, dynamics, and efficacy; the latter deals with symbolism, communication, and meanings. Scholars have recognised the need to mediate between these two positions. ${ }^{174}$ In the present study, we examine both aspects of ritual action: the formal first and then the agency. Finally, the role of the human body in ritual performances and the establishment of social order by those performances connect with the notion of authority invested in the ritual. In order to relieve the problem of infidelity on the part of a group of people, rituals, according to Ray A. Rappaport, use the collocation of symbolic and indexical elements. Symbolic elements refer to the relationship established between the sign and the object, and indexical elements refer to the bodily gestures in the ritual that acknowledge and embody the acceptance of the worldview espoused in the ritual. Indeed, "by performing a liturgical order the participants accept, and indicate to themselves and to others that they accept whatever is encoded in the canon of the order."175

Recent scholarship has seen the downplaying of the significance of baptism in Paul's thought by describing it as a mere metaphor, a position championed by James D. Dunn and

\footnotetext{
${ }^{169}$ Hellholm, "Vorgeformte Tauftraditionen," 451-52.

170 J. L. Austin, How to Do Things with Words (Oxford: Oxford University Press, 1962); J. R. Searle, Speech Acts (Cambridge: Cambridge University Press, 1969).

${ }^{171}$ Austin, How to Do Things, 130.

172 Ibid., 132.

${ }^{173}$ For agency, see Kenneth Burkes, Dramatism and Development (Barre, MA: Clark University Press, 1972). On formal actions, see Grimes, Craft of Ritual Studies, and Staal, "Meaninglessness," 9-14.

174 Barry Stephenson, "Ritual as Action," 46.

175 Rappaport, Ritual and Religion, 119.
} 
Gordon Fee. Dunn argues that baptismal references such as 1 Cor 6:11, 12:13, and Gal 3:27 should be understood as a metaphor depicting the conversion-initiation experience rather than an allusion to actual ritual practice. ${ }^{176}$ In other words, baptismal allusions are a metaphor for "inward, subjective (even mystical) aspects of the whole event like repentance, forgiveness, union with Christ." ${ }^{177}$ Fee points out that scholars have often assumed a ritual background is associated with the verb $\beta \alpha \pi \tau i \zeta \omega$ in 1 Cor $12: 13 .{ }^{178}$ Fee denies any link between the water rite and the reception of the Spirit in Paul's corpus, arguing that the former is mainly associated with the Lordship of Christ. ${ }^{179}$ By implication, Fee sees other baptismal allusions in Paul's writings as metaphors.

Whilst Dunn and Fee have laid bare the fact that scholars have taken the ritual denotation in these baptismal passages for granted, their treatment of metaphor as a literary device has failed to account for the ritual behind the language associated with ritual washing. This failure lies in not recognising that metaphor can be appropriated differently in cultural anthropology. The investigation of metaphor and metonymy in anthropology in recent years has discovered the interplay between metaphor and metonymy and religious ritual activities. For instance, James Fernandez has observed that, in the liturgy of any ritual composed of a series of ceremonial scenes, metaphor and metonymy are the sign-images by which each scene of the ceremony is organised and performed. ${ }^{180}$ Each scene actualises the image-plan in the metaphor and metonymy for the participant. ${ }^{181}$ Through such ceremonial scenes, the participants "become the metaphor predicated upon them." "182 This insight has since been taken up by scholars working with biblical texts, including Howard Eilberg-Schwartz. ${ }^{183}$ In his work on ancient Judaism, Eilberg-Schwartz devotes a chapter to discussing animal and agricultural metaphors in Israelite thought. ${ }^{184} \mathrm{He}$ argues that these metaphors served as a foundation in the ancient Israelites' religious rituals. ${ }^{185}$ As such, religious rituals actualise the metaphors that

176 James D. G. Dunn, Baptism in the Holy Spirit: A Re-Examination of the New Testament Teaching on the Gift of the Spirit in Relation to Pentecostalism Today (London: SCM Press, 1970), 127-31, and Dunn, "'Baptised' as Metaphor," 294-310.

${ }^{177}$ Dunn, Baptism in the Holy Spirit, 6-7.

${ }^{178}$ Gordon Fee, God's Empowering Presence: The Holy Spirit in the Letters of Paul (Peabody, MA: Hendrickson, 1994), 179n364.

${ }^{179}$ Fee, God's Empowering Presence, 179.

${ }^{180}$ Fernandez, Persuasions and Performances, 42-43.

181 Ibid., 43.

182 Ibid., 43.

${ }^{183}$ Another recent work that uses this finding is Stephen Richard Turley, The Ritualized Revelation of the Messianic Age: Washing and Meals in Galatians and 1 Corinthians, JSNTSup 544 (Bloomsbury: T\&T Clark, 2015).

${ }^{184}$ Eilberg-Schwartz, Savage in Judaism, 115-40.

${ }^{185}$ Eilberg-Schwartz, Savage in Judaism, 122. 
dominate ancient Israelite society. ${ }^{186}$ Thus, with this understanding of metaphor as an instrument for transformation on the part of the participant, we can look at baptismal allusions in Paul's corpus in a different light, avoiding the danger of falling into one of the extreme positions: sacramentalist or literalist.

\subsubsection{Corinthians 12:13}

Baptismal tradition: There is a change of person from third-person singular to the first-person plural, which attests to the self-contained pre-Pauline tradition but is still well suited to this context. ${ }^{187} \mathrm{~A}$ change of person indicating the author is using a tradition or source material distinguishable from the surrounding text is also found elsewhere in the New Testament. For instance, from the context in Gal 3:26-28, there is a change of person from a first-person plural in 3:25 ( $\dot{\varepsilon} \sigma \mu \varepsilon v)$ to a second-person plural in the tradition ( $\dot{v} \mu \varepsilon \tilde{\varepsilon} \varsigma)$. Another example is 1 Tim $3: 16$, where the first person, which begins in verse 14 , abruptly changes to the third person in 3:16b. The exalted language of "Proklamation der Einheit der Gemeinde" indicates a technical religious speech. ${ }^{188}$ The widely recognised Christ hymn in Phil 2:6-11 also exhibits exalted and poetic language suitable for a liturgical context. The tripartite phrases of "Jew-Greek," "slave-free," and "male-female" appear in a slightly variegated form in 1 Cor 12:13, Gal 3:2628, Col 3:10-11, and other early Christian literature indicates that the tradition had gained widespread currency. ${ }^{189}$

Performative Indicators: The verb $\dot{\beta} \beta \pi \tau i \dot{\sigma} \theta \eta \mu \varepsilon v$ in the aorist tense denotes the performance of

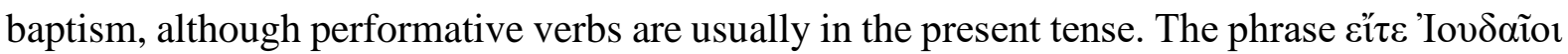

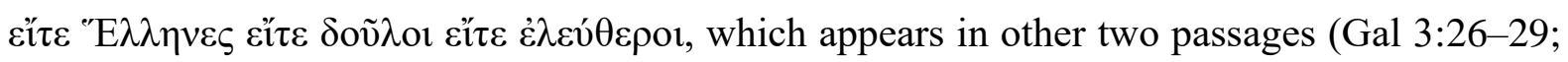
Col 3:9-11), is declaratory, a solemn pronouncement on the newly baptised candidate who has

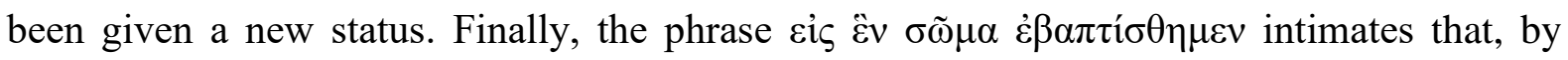
undergoing the baptism ritual, the candidate fully accepts the worldview and symbolic message encoded therein through the indexical gesture of immersion and emersion.

\footnotetext{
186 Ibid., 122.

${ }^{187}$ Hellholm, "Vorgeformte Tauftraditionen," 423, and Anders Eriksson, Traditions as Rhetorical Proof: Pauline Argumentation in 1 Corinthians, ConBNT 29 (Stockholm: Almqvist \& Wiksell, 1998), 127.

188 Dieter Lührmann, "Wo man nicht Sklave oder Freier ist: Überlegungen zur Struktur früchristlicher Gemeinden," WD 13 (1975): 57.

${ }^{189}$ Cf. Eph 6:8 and Ign Smyrn 1:2. For the formula used in apocryphal books, see Henning Paulsen, "Einheit und Freiheit der Söhne Gottes: Gal 3:26-29," ZNW 71 (1980): 80-85; for the reception history amongst gnostic groups, see Wayne A. Meeks, "The Image of the Androgyne: Some Uses of a Symbol in Earliest Christianity," HR 13 (1974): 189-97.
} 
Metaphor Predication: Here Paul relates baptism to Christ's body and baptism in the Spirit. To be identified with the metaphorical imageries, one needs to participate in the ritual scenes of baptism that are related to the metaphors. Thus, baptising in the Spirit is participating in water baptism and being incorporated into Christ's body. There are two reasons to support this observation. First, Turley has demonstrated that Paul's understanding of the Spirit experience in the Corinthians epistles is linked with Ezekiel 36:25-27. ${ }^{190}$ He examines four features that both passages share to determine that Paul sees baptism ritual as the actualisation of Spirit promised in Ezekiel: ritual cleansing and eschatological, ethical, and corporate frames of reference. ${ }^{191} \mathrm{He}$ finds that Paul's pneumatology does exhibit these features comparable to Ezekiel 36:25-27 and that the baptism ritual is thus the fulfilment of Spirit promised in Ezekiel. ${ }^{192}$ Second, Paul's endowing baptism the ritual with imagery of the body has a ritual precedent. Margert M. Mitchell notes that parallels exist between Paul's ritualised political body in baptism and the Graeco-Roman shared political unity in ritual participation. ${ }^{193}$ In the Greco-Roman world, various factions reunited with allies through common sacrifices (Dionysius, Ant. rom. 4.25.4-5; 26.3; 6.6.1, 79.2) and meals (Lucan B. Civ. 4.196-68). Classical authors often appeal to the role of rites for stabilising a society for the "health" of the "body politic" (Or. 41.10; cf. Or. 38.22; Or. 23.30-31; Ab Urbe Condita, 2.32.9-12).

\subsubsection{Corinthians 6:11}

Baptism tradition: The language of washing in Acts 22:16 referring to baptism naturally conjures up the same pictorial image in 1 Cor 6:11. ${ }^{194}$ Although the usual verb signifying the baptism ritual, $\beta \alpha \pi \tau i \zeta \omega$, is not present in the passage, the verb $\alpha \pi \circ \lambda \circ v^{\prime} \varepsilon \sigma \theta \alpha 1$ is observed as a special baptismal language drawing from cultic-liturgical tradition. ${ }^{195}$ The sequence of the phrase with the $\dot{\alpha} \lambda \lambda \dot{\alpha}$ construction, which stands out from the context, is regarded as a tradition. ${ }^{196}$ Finally, Paul's reference to "the name of the Lord Jesus Christ" suggests a cultic activity, which invites some comments.

190 Turley, The Ritualized Revelation, 86-91.

191 Ibid., 92-96.

192 Ibid., 96.

${ }^{193}$ Margaret M. Mitchell, Paul and the Rhetoric of Reconciliation (Tübingen: Mohr Siebeck, 1992), 141.

${ }^{194}$ Beasley-Murray, Baptism, 163; Rudolf Schnackenburg, Baptism in the Thought of St. Paul, trans. G. R. Beasley-Murray (Oxford: Basil Blackwell, 1964), 3.

195 Joseph Ysebaert, Greek Baptismal Terminology: Its Origin and Early Development (Nijmegen: Dekker \& van de Vegt, 1962), 63. For its verbal usage for baptismal language, see Acts 22:16; Eph 5:26; Tit 3:5; Rev 1:5, and for its substantive usage, see Rom 3:24; Col 3:14; Eph 1:7; Heb 9:15.

${ }^{196}$ F. Hahn, "Taufe und Rechtfertigung: Ein Beitrag zur paulinischen Theologie in ihrer Vor-und Nachgeschite," in Rechtfertigung: Festschrift für Ernest Käsemann, ed. J. Friedrich et al. (Tübingen: Mohr Siebeck, 1976), 246-47; Schnelle, Gerechtigkeit, 39-42; and Hellholm, "Vorgeformte Tauftraditionen," 431. 
There are three basic form of 'in the name' formula in the New Testament as shown below.

sic

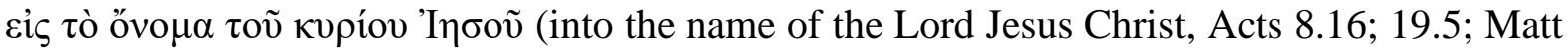
$28: 19$; cf. 1 Cor $1.13,15)$

$\dot{\varepsilon} v$

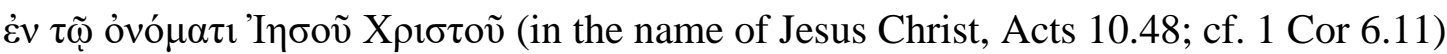

$\dot{\varepsilon} \pi \grave{\imath}$

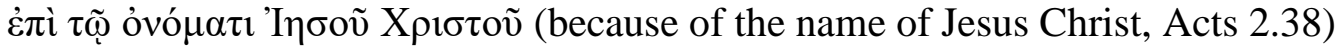

The first formula "into the name" construct appears in worship context, either relating to the invocation of the name or to the ritual of washing. The second formula "in the name of" is common and is employed with various verbal actions in various contexts such as "come in the name of the Lord" (Matt 23.39), "receive a child in my name" (Mark 9.38), "judge in the name of Lord Jesus" (1 Cor 5:4), and to name a few. The third formula "because of the name" is widely used in the New Testament with examples of "received a child because of my name (Matt 18.5)," "perform a mighty deed because of my name (Mark 9:39)," "many come because of my name (Mark 13.6)," and just to cite a few. Given the extensive usage the last two formula, it may represent a well-established usage in the early Christ movement, since there are a few examples of such usage in the Early Judaism that may have been taken over by the Christ followers. ${ }^{197}$

Regarding the meaning of "in the name" formula associated with baptism ritual, there are three principal views on the significance of the phrase. The first view sees the meaning of transference of ownership and relationship of belonging in the phrase. According to this view, a baptised person becomes the property of the Lord Jesus like a sum of money paid to a person's

${ }^{197}$ Lars Hartman, "Usages—-Some Notes on the Baptismal Name-Formulae" in Ablution, Initiation, and Baptism: Late Antiquity, Early Judaism, and Early Christianity (ed. David Hellholm et al.; Berlin: De Gruyter, 2011), 400-03. "In the name": Joseph and. Aseneth 9:1; 15:7; Testament of Solomon 67 and 115; Prayer of Joseph. fragm. 190. "Because of the name": 1 Enoch 10:2; Testament of Asher 2:4. 
bank account. Wilhem Heitmüller is the proponent of this view, who argues on the basis of the Greco-Roman documents that use banking terminology to refer to the name of the person who disposes an account in a bank. With this financial undertone, the baptism into the name of Jesus, then, means that a candidate who is baptised is transferred into the pocession of another person. ${ }^{198}$

The second view probes into the original meaning of Semantic expressions of "into the

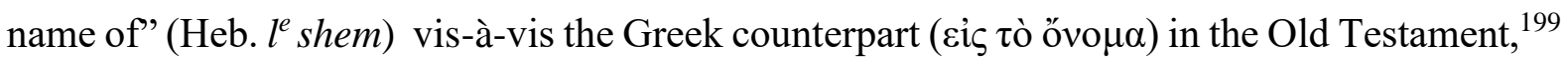
Mishnah, and Talmud, with the basic meaning of "with respect to." ${ }^{200}$ It has a wide range of applications used in various context, denoting the fundamental reference or purpose of action or rite. Used in baptismal context, the phrase "referred to an authority behind the rite, who conferred significance on the rite and made the formula meaningful." ${ }^{201}$ Thus, the authority behind the baptism ritual is linked with the person of Jesus Christ and his salvific works (i.e. death and resurrection) and his teachings. ${ }^{202}$ Finally, the third view sees the inextricable connection between Christ's salvific work and his name, and thus a person who is baptised into the name of Jesus is to be endowed with benefits of salvation accomplished by Christ. ${ }^{203}$

Since this study uses the performance-oriented ritual theories, we can interpret the "in the name" formula as part of a crucial element in the baptism performance that affects the presence of Jesus in the one who baptizes. As we noted earlier in ritual actor, the ritual agents in baptism involve both human and divine persons. The human person administers the rite of baptism in the name of Jesus, whose divine presence is made manifested by the meditation of the Spirit as it dwells in the baptised candidates (Acts 10:44-47; 11:13-17). We will discuss more on the agency of the Spirit in later section, but it suffices to note that the invocation of the name of Jesus is a locus point in which the synergetic work of divine and human agents in the ritual performance manifests itself.

Now we have discussed the meaning of the name formula in baptism, a natural question arises regarding the title kúptos in the name formula, whether it is intended for the divine identity of Jesus. To begin, we note how the New Testament writers apply kyrios-title to Jesus.

198 Wilhelm Heitmüller, "Im Namen Jesu“ Eine religionsgeschichtliche Untersuchung zum Neuen Testament (FRLANT 1.2) (Göttingen: Vandenhoeck \& Ruprecht 1903).

${ }^{199}$ Examples in the Old Testament: praising God in his name (Ps 89:13, 17); one prays in God's name (1 Kgs 18:24); one swear, bless, or curse in God name (Deut 6:13, 10:8, 2 Kgs 2:24).

200 see Beasley-Murry, Baptism, p. 90-92.

${ }^{201}$ Lars Hartman, “"Into the Name of the Lord Jesus,"” p. 45.

${ }^{202}$ Ibid., p.45. 97.

${ }^{203}$ G. Delling, Die Zueignung des Heils in der Taufe (Berlin: Evangelische Verlagsanstalt, 1961), esp. 
In the gospels various figures have been addressed as кúpıє (which translated as Sir), including the earthly Jesus (Mark 7:28; Matt 15:27; 8:6,8). ${ }^{204}$ However, the title takes on religious overtone when Jesus's disciples acknowledge him to be the кúpı̧, after having witnessed the miraculous works of Jesus (Luke 5:8; 12:41-42). ${ }^{205}$ In such cases, the gospel writers read the post-Easter experience of Jesus into the account of his' earthly ministry. ${ }^{206}$ In Paul's letters, we see a wider application of kyrios-title to Jesus in all stages of his salvific works: the preincarnational kyrios Jesus in the form of God (Phil 2:10-11), the ever-continuing presence of "the Lord" Jesus amongst the Christ community expressed in the prepositional phrases: $\dot{\varepsilon} v$

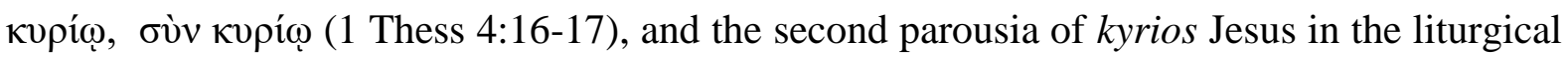

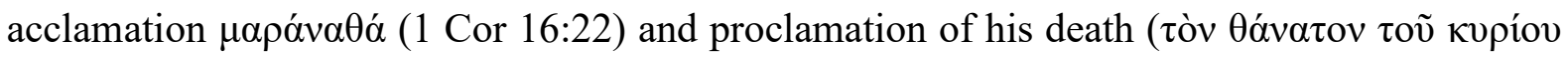

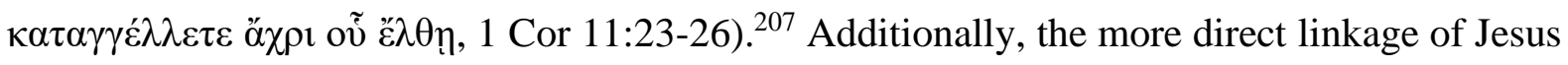
with kópros can be seen in Paul's application of Yahweh texts from the Greek Septuagint that renders the tetragrammaton YHWH as кúpıoৎ to Christ as referent. Paul identifies Christ with the divine name of Yahweh (Rom 10:13), with the worship reserved for God (Rom 14:11), with the divine attributes of God (1 Cor 1:31; 2:16; 2 Cor 10:17), and with the lordship of Yahweh over his creation (1 Cor 10:26).

Given such intimate connection between Jesus and the God Yahweh in the early Christ movement, how can we understand the relationship between the two: is Jesus recognised as Yahweh himself by early Christ followers or is Jesus somehow a distinct being that participates in the transcendence of Yahweh? According to Cape David Bryan, since Paul uses kyrios that was employed to translate the divine name in LXX and in other contemporary Jewish writings as a Christological title, "[i]t suggests that he believed that Christ was in some sense Yahweh Himself, manifest as the Messiah."208 This is seen in the devotion of Jesus in the earliest days of Christ movement that gives adoration and worship to him reserved for God (Rom 1:3-4; 10:9-10; 1 Cor 1:2; 5:4; 11:20; 16:22; Phil 2:6-11). Whereas Bryan identifies Jesus with Yahweh himself, other scholars have recognised the distinction and unity between the two. Fitzmyer, having examined the kyrios title for Christ, observes that "Jesus as sharing in some sense in the transcendence of Yahweh, that he was somehow on a par with him. This, however,

${ }^{204}$ Joseph A. Fitzmyer, “The Semitic Background of the New Testament Kyrios-Title.” In A Wandering Aramean: Collected Aramaic Essays. By Joseph A. Fitzmyer, 115-142. (Society of Biblical Literature Monograph 25. Missoula, MT: Scholars Press, 1979), 127.

${ }^{205}$ Fitzmyer, ““'The Semitic Background of the New Testament Kyrios-Title,” 127.

206 Ibid., 127.

${ }^{207}$ Ibid., 127-30.

208 David B. Capes, Old Testament Yahweh Texts in Paul's Christology (Wissenschaftliche Untersuchungen zum Neuen Testament 2. Tübingen, Germany: J. C. B. Mohr, 1992), 278. 
is meant in an egalitarian sense, not in an identifying sense, since Jesus was never hailed as אבא It involves a Gleichsetzung, but not an Identifizierung." ${ }^{209}$ Similarly, C. Kavin Rowe notes the differentiation and unity between God and Jesus identity in the Lukan narrative (Luke 1 and 2) regarding the ministry of Jesus through the shared title kyrios. ${ }^{210}$ We propose that a more nuanced understanding of Jesus and his link with YHWH through kyrios title should be adopted. First, we need to recognise that there is an ambiguity in the New Testament regarding the exact relation between Jesus and God. At the one hand, there is a strong identification of Jesus with God by ascribing him the adoration, divine attributes, and redemptive role of God. On the other hand, Jesus is clearly a separate entity distinct from God as seen in the salutations in Paul's epistle greetings (Rom 1:7; 1 Cor 1:1-2; Phil 1:1; 1 Thess 1:1; 2 Thess 1:1) and in those instances where Jesus is described as an instrument through whom God redeems the whole human race (Rom 3:24; Eph 1:7). ${ }^{211}$ Second, this ambiguity suggests that early Christ followers are binitarian, worshipping God alongside kyrios Christ (1 Cor 8:6). ${ }^{212}$ Finally, the exact relation between God and Christ as articulated in the Nicene Creed constitutes a later endeavour by the Christ followers to clarify the ambiguity left from the New Testament era.

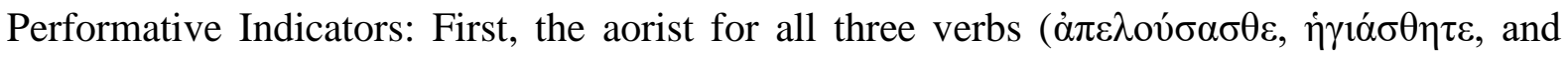
$\dot{\varepsilon} \delta 1 \kappa \alpha \iota \dot{\theta} \theta \eta \tau)$ points to a specific act in the past that is foundational to the current status of Corinthians before God. ${ }^{213}$ Second the word $\dot{\alpha} \pi \mathrm{\alpha} \lambda$ ov́ $\omega$ denotes the cleansing of bodily filth, involving bodily relation to the ritual; one accepts purification of the body from physical,

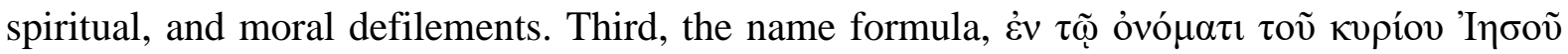

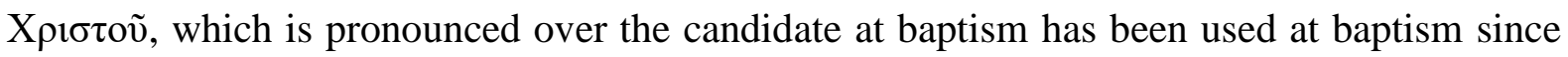
the inception of the Christ movement (Acts 2:38; 8:16; 10:48; 19:5).

Metaphor Predication: Identifying washing imagery with ablution and initiation rites is common in ancient Greco-Roman religions, including Judaism. The question is not whether

\footnotetext{
209 Joseph A. Fitzmyer, “The Semitic Background of the New Testament Kyrios-Title.” In A Wandering Aramean: Collected Aramaic Essays. By Joseph A. Fitzmyer, 115-142. (Society of Biblical Literature Monograph 25. Missoula, MT: Scholars Press, 1979), 130

${ }^{210}$ C. Kavin. Rowe, Early Narrative Christology: The Lord in the Gospel of Luke (Beihefte zur Zeitschrift für die neutestestamentliche Wissenschaft und die Kunde der älteren Kirche. Grand Rapids, MI: Baker Academic, 2009)

${ }^{211}$ For more on the syntactical analysis of divine action expressed in "in Christ" language see J. Thomas Hewitt, "In Messiah: Messiah Discourse in Ancient Judaism and 'In Christ' Language in Paul” (Ph.D. diss., University of Edinburgh, 2019), 183-267.

${ }^{212}$ Larry W. Hurtado, One God, One Lord: Early Christian Devotion and Ancient Jewish Monotheism, $3^{\text {rd }}$ ed. (New Delhi: Bloomsbuty T\&T Clark, 2015), 153-57.

${ }^{213}$ Beasley-Murray, Baptism, 163; Schnackenburg, Baptism in the Thought, 3.
} 
washing symbolism gives rise to ablution rites or vice versa. Given that water is an essential element in these rites, it naturally lends itself to the washing or cleansing metaphor, and this in turn reinforces the cleansing notion of the rite. The Qumran sect, which was contemporaneous with the nascent Christ movement, offers an example of an ablution rite practiced in the ancient world. The purification rite is accompanied by pervasive washing symbolism. The purification liturgies of the Qumran sect speak of the sanctification of sect members through ritual purification (4Q512 33, 35), purification from moral corruption (4Q512 29-30; 1-3) defilement (4Q512 4-6), and disease (4Q512 27), along with purification through the establishment of a law of atonement (4Q414 13). It is interesting to note one of the liturgical fragments contains a juxtaposition of purification and righteousness: "You distinguish us between the impure and the pure ... to You with a purification of righteousness and ... with

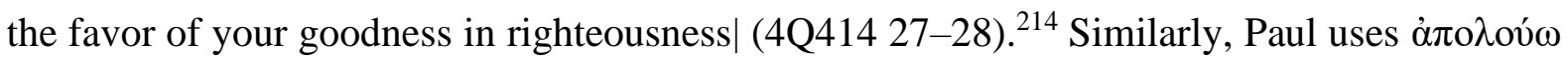
alongside $\delta$ เк $\alpha$ ó $\omega$ in the series of $\dot{\alpha} \lambda \lambda$ ' constructions, suggesting that baptism and justification are closely connected. ${ }^{215}$ It is worth to note that in early Greek thought the concept of purification relates to the legal sense of acquitting one's punishment or sin in a context of

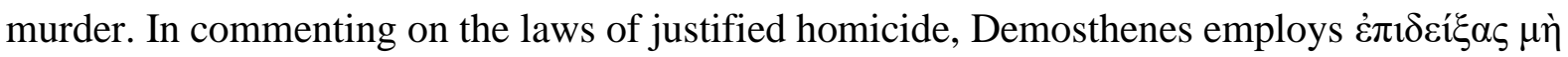
$\kappa \alpha \theta \alpha \rho$ ó $\varsigma$ for the prove of involuntary homicide, ${ }^{216}$ indicating pure and not liable to punishment are synonymous. Accordingly, a guilty person is said to be polluted and excluded from society, in need of purification. In the purification ritual, the participant is silent with his head veiled, coupled with symbolic actions that narrate the murder's story and his supplications. ${ }^{217}$ The participant would sit at the hearth or threshold, expressing his complete submission and passivity. ${ }^{218}$ What results from this homicide purification rite is the reintegration of the participant into the social and religious life. ${ }^{219}$ Paul in 1 Cor 6:9-10 delineates a litany of wrongdoers (ó $\delta 1 \kappa o t)$, and even though murderer is not mentioned in the list, it denotes a similar notion that people in these categories are polluted in need of purification, so that they might be integrated into a new society or community, that is, the kingdom of God. Immediately in verse

214 Translation from James R. Davila, Liturgical Works: Eerdmans Commentaries on the Dead Sea Scrolls, ed. Martin G. Abegg, Jr. and Peter W. Flint (Grand Rapids: Eerdmans, 2000), 288-89.

${ }^{215}$ Morales, "Baptism and Union," 166.

216 23.74; 9.44. Robert Parker, Miasma : Pollution and Purification in Early Greek Religion / Robert Parker (Oxford: Clarendon, 1983), 367.

217 Parker, Miasma, 371.

218 Ibid., 371-72.

${ }^{219}$ For the intertwining relationship between purification and acquittal of punishment in legal matters see Hannah Willey, "Social-status, Legislation, and pollution in Plato's Euthyphro" in Purity and Purification in the Ancient Greek World, ed. Jan-Mathieu Carbon and Saskia Peels-Matthey (Liege: Presses Universitaires de Liege, 2018), 113-31. 
11 Paul exclaims that the Corinthian communities have made pure or justified through the washing of baptism ritual. Given the pervasive legal overtone in 1 Cor 6, Paul may have drawn on this early Greek notion of purification regarding acquittal of punishment.

\subsubsection{Galatians 3:27-28}

Baptism tradition: First, the usage of $\gamma \grave{\alpha} \rho$ has been observed to be referential, alluding to information previously known to the original audience. ${ }^{220}$ Second, Paul abruptly shifts the pronouns and verbs from the first-person plural ("we," "our") in vv. 23-25 to the second-person plural ("you," Greek plurals) in vv. 26-28. ${ }^{221}$ Third, of the three contrasting pairs in v. 28 (Jew/Greek, slave/free, male/female), only the first has direct relevance to the immediate context, while the second may echo the slave metaphor used elsewhere in the letter and the third one appears to be irrelevant to the entire letter. ${ }^{222}$ Fourth, it seems that, without the intervening vv. 27-28, Gal 3:29 naturally and logically follows 3:26 in concluding that those of Christ are Abraham's heirs according to the promise. ${ }^{223}$ Craig S. Keener dismisses the digression as a hardly unique feature that is actually common in Paul's letters. ${ }^{224}$ Be that as it may, one could use this argument to other so-called baptismal traditions in Paul's letters and explain away any elements that appear to disrupt Paul's thought, and Keener does not supply any example of this same feature in Paul's letters. Fifth, the redundancy of the phrase "in Christ Jesus" in v. 26 and v. 28 may signal to the readers that Paul is returning to his own line of argument from the cited material. ${ }^{225}$ Finally, the parallels in 1 Cor 7:18-22, 12:13, Col 3:11, and John 17:21 attest to the prevalence of the tradition in the early Christ communities. ${ }^{226}$

${ }^{220}$ Atsuhiro Asano, Community-Identity Construction in Galatians: Exegetical, Social-Anthropological and Socio-Historical Studies, JSNTSup 285 (London: T\&T Clark International, 2005), 181; Richard Longenecker, Word Biblical Commentary. Volume 41, Galatians (Dallas: Word Books, 1990), 151.

${ }^{221}$ Martinus C. de Boer, Galatians: A Commentary, NTL (Louisville: Westminster John Knox Press, 2011), 245, and A. Andrew Das, Galatians: Concordia Commentary (Saint Louis: Concordia Publishing House, 2014), 380.

${ }^{222}$ De Boer, Galatians, 245, and Das, Galatians, 380. Having examined the evidence for the possible sources behind Gal 3:28, Gesila Nneka Uzukwu finds it lacking and argues that Gal 3:28c is well integrated into Paul's argument in Gal 3 as a whole. By using a thematic-epistolographical approach that links Gen 17 (LXX) with Gal 3 on the theme of promise, she observes that "Paul used the expressions to present how physical affinity or physical genealogy had been reversed in favour of spiritual genealogy for the primary recipients and secondary beneficiaries of the promise"; Gesila Nneka Uzukwu, The Unity of Male and Female in Jesus Christ: An Exegetical Study of Galatians 3.28c in Light of Paul's Theology of Promise, LNTS 531 (London: Bloomsbury T\&T Clark, 2015), 205. Uzukwu's work is valid in its own right, as she seeks to understand Gal 3:28c as part of the finished text of Galatians. However, what concerns us here is the possible baptism ritual background behind Gal 3:28 and isolating it from the surrounding text so that we can have a ritual text for ritual analysis.

${ }^{223}$ Longenecker, Galatians, 154; Das, Galatians, 380.

${ }^{224}$ Craig S. Keener, Galatians: A Commentary (Grand Rapids: Baker Academic, 2019), 295.

${ }^{225}$ De Boer, Galatians, 245, and Das, Galatians, 381.

${ }^{226}$ De Boer, Galatians, 245-46, and Jürgen Becker, Der Brief an die Galater, NTD 8/1 (Göttingen: Vandenhoeck \& Ruprecht, 1998), 60. 
Performative indicators: First, there are two declarative statements embedded in this passage:

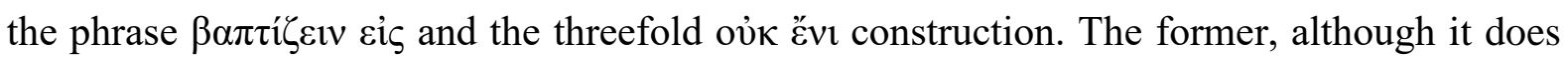

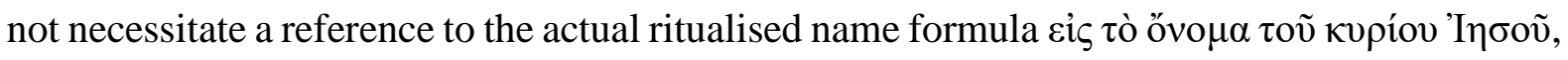
could well be an invocation of the Lord's name over the baptizands, a common practice in the early Christ movement (cf. 1 Cor 1:13-17; 6:11; Acts 2:38; 8:16; 10:48; 19:5). Moreover,

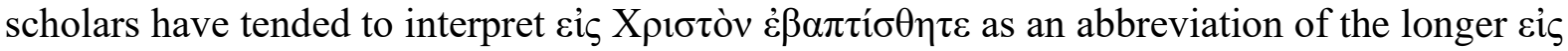

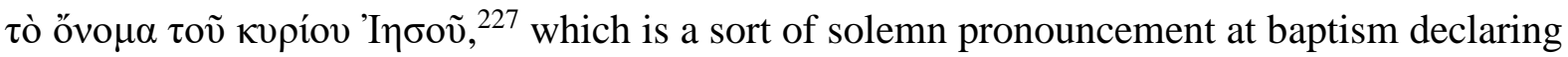
a new status bestowed upon those being baptised. This is intimated by its frequent occurrence in other Pauline writings that refer to the baptism ritual (1 Cor 12:13; Col 3:11). Second, most verbs in the declarative statement, which denotes ritual action, are in the present tense $-\dot{\varepsilon} \sigma \tau \varepsilon$ in vv. 26 and 27 - indicating a ritual performance. The two aorist verbs, $\dot{\varepsilon} \beta \alpha \pi \tau i ́ \sigma \theta \eta \tau \varepsilon$ and $\dot{\varepsilon} v \varepsilon \delta v ́ \sigma \alpha \sigma \theta \varepsilon$, denote baptismal performance. Third, the verb $\dot{\varepsilon} v \varepsilon \delta v ́ \sigma \alpha \sigma \theta \varepsilon$ signifies the involvement of the body as the locus of acceptance on the part of the participant. As most scholars see Paul's use of the verb $\dot{\varepsilon} v \delta v ́ \omega$ as paralleling $\beta \alpha \pi \tau i \zeta \omega,{ }^{228}$ the significance of the clothing reference lies in the Galatian's bodily relation to Christ, which is analogous to the bodily relation to the garment. ${ }^{229}$ Finally, this bodily acceptance results in an emerging social order called communitas, which is defined by equality. Most commentators consider Gal 3:28 to be an example of early Christian communitas. ${ }^{230}$

Metaphorical Predication: Paul's use of clothing symbolism in baptism has ritual precedents. In the mystery religions, the clothing motif was used in a variety of ways. A clear example is found in Apuleius's Metamorphoses, where wearing a new garment was a crucial moment in the initiation rite. Lucius, the main character in the story, dons a ritual garment three times at three different stages of the initiation ritual. Lucius first wears a white linen garment shortly after being restored to human form from ass-man (XI. 13). This symbolises the restoration from

${ }^{227}$ Gerhard Barth, Die Taufe in frühchristlicher Zeit (Neukirchen-Vluyn: Neukirchener, 1981), 44, 46; Beasley-Murray, Baptism, 90-92; Longenecker, Galatians, 155; Richard B. Hays, The Letter to the Galatians: Introduction, Commentary, and Reflections, NIB 11 (Nashville: Abingdon Press, 2000), 155.

${ }^{228}$ Jung Hoon Kim, The Significance of Clothing Imagery in the Pauline Corpus, JSNTSup 268 (London: T\&T Clark International, 2004), 115; Ronald Y. K. Fung, The Epistle to the Galatians (Grand Rapids: Eerdmans, 1988), 172; Barth, Taufe, 105; Hans Dieter Betz, Galatians A Commentary on Paul's Letter to the Churches In Galatia (Hermeneia; Philadelphia: Fortress Press, 1979), 186.

${ }^{229}$ Kim, Clothing Imagery, 115.

230 A. J. M. Wedderburn, Baptism and Resurrection. Studies in Pauline Theology against its GraecoRoman Background (Tübingen: Mohr Siebeck, 1987); Strecker, Die liminale Theologie, 300, 351-58; Asano, Community-Identity, 197. 
death to life and anticipation of the future life. ${ }^{231}$ The second time Lucius wears a new linen garment is at the secret initiation ceremony, which symbolises "the new life-out-of-death" through union with Isis (XI. 23). ${ }^{232}$ The third time, Lucius dons twelve religious robes at the public display after his initiation, symbolising "the radiance of restored life accomplished through his identification with gods" (XI. 24). ${ }^{233}$ The importance of the clothing motif in religious rituals in the Greco-Roman world sheds valuable light on Paul's use of a clothing reference in connection to baptism. Although it is difficult to determine whether the clothing reference gives rise to the practice of wearing a garment during or after the baptism or vice versa, Second Temple literature describes the attire for a bathing ritual (B. J. 2.128-29; 2.161; 2.137-42; Jos. Asen. 14.12-13). ${ }^{234}$

\subsubsection{Romans 6:1-11}

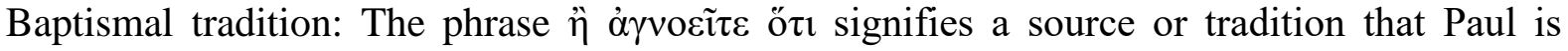
appealing to in the verses that follow. ${ }^{235}$ Regarding the traditional materials that Paul is quoting, Hellholm suggests that Paul draws from the same kerygma of Christ's death and resurrection that occurs in 1 Cor $15: 3-5: 236$

1 Cor. $15: 3-5$

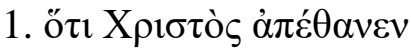

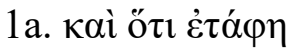

Rom. 6:3-4/8

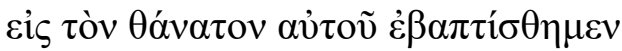

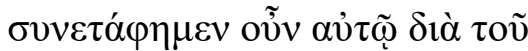

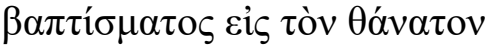

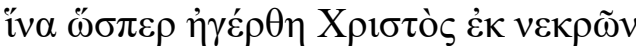

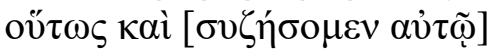

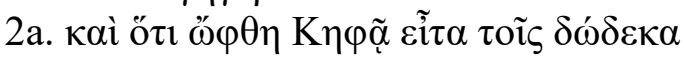

Granted, one may argue that this does not necessarily prove a ritual background since it could be a fragment of an early credo statement. However, Paul does use the verb $\beta \alpha \pi \tau i \zeta \omega$ in this

${ }^{231} \mathrm{Kim}$, Clothing Imagery, 83-85.

232 Ibid., 90.

233 Ibid., 91.

${ }^{234}$ See Laurie Guy, "Naked' Baptism in the Early Church: The Rhetoric and the Reality," JRH 27, no. 2 (2003): 133-42.

${ }^{235}$ Charles Kingsley Barrett, A Commentary on the Epistle to the Romans, 2d ed, BNTC; HNTC (London: Black; New York: Harper, 1991), 121-22; Otto Michael, Der Brief an die Römer, 14th ed., KEK 4 (Göttingen: Vandenhoeck \& Ruprecht, 1978), 205; John Murray, The Epistle to the Romans: The English Text with Introduction, Exposition, and Notes, NICNT (London: Marshall, Morgan \& Scott, 1959. Repr.; Grand Rapids: Eerdmans, 1997), 214; C. E. B. Cranfield, A Critical and Exegetical Commentary on the Epistle to the Romans, Volume 1, ICC (Edinburgh: T\&T Clark, 1975), 300; Ernst Käsemann, Commentary on Romans, trans. G. W. Bromiley (Grand Rapids: Eerdmans, 1980), 165; Ulrich Wilckens, Der Brief an die Römer, Volume 2, EKKNT 6 (Zurich: Benziger, 1978), 11; Robert Tannehill, Dying and Rising with Christ: A Study in Pauline Theology, BZNW 32 (Berlin: Töpelmann, 1967), 12-14.

${ }^{236}$ Hellholm, "Vorgeformte Tauftraditionen," 442. 
pericope, and the usual verbal construction of $\varepsilon i \varsigma . . . \dot{\varepsilon} \beta \alpha \pi \tau i \sigma \theta \eta \mu \varepsilon v$ when he appeals to the baptism ritual in his other letters. This could intimate that Paul is merging the credo tradition with baptism to form a new understanding by connecting the Christ event with the baptism ritual. Paul's creative use of tradition is attested by how he shapes the materials. Interpreters have noted that Paul does not complete the parallelism of Christ's resurrection with the believers. ${ }^{237}$ Whatever the exact circumstances surrounding Paul's writing, it is difficult to ascertain the historical reason why Paul shapes his material the way he does. The burden of the pericope is not so much about the parallels of Christ's fate with that of his believers as about participation in the Christ event through baptism, denoted by the prepositions $\varepsilon \tilde{\zeta} \varsigma$ and $\sigma v v$.

Performative Indicators: First, the verbs $\dot{\varepsilon} \beta \alpha \pi \tau i ́ \sigma \theta \eta \mu \varepsilon v$ and $\eta \gamma \gamma \dot{\varepsilon} \rho \theta \eta$ signify the performance of baptism in immersion and emersion. Second, although the bodily relation to the ritual is not

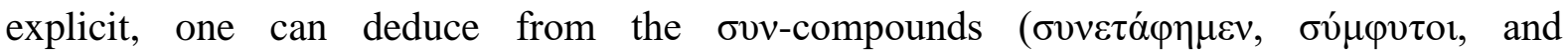

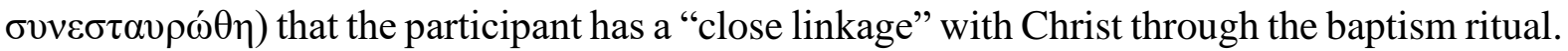

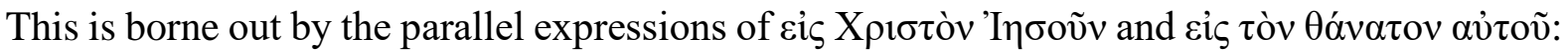
that the baptised not only participate in Christ's death but also share in its effects. ${ }^{238}$

Metaphorical Predication: Paul identifies the baptism ritual with metaphorical imageries of Christ's death, burial, and resurrection. The performance of baptism is to re-enact the Christ event, and the participant is to identify with it. However, some scholars have asked how baptism can be perceived as a repetition of Christ's death and burial since Christ's death was not a death by drowning. ${ }^{239}$ In response, given that baptism symbolises death through plunging into water, the reference to burial is not implausible, as the custom was to bury people in caves. N. H. Taylor cautions that we should not read our own burial customs into the text and that it might be more appropriately rendered for its time as "we have undergone funeral rites with him [Christ]." ${ }^{240}$ We should note that Paul is not drawing a strict parallel between the Christ event

${ }^{237}$ A. J. M. Wedderburn, "Hellenistic Christian Traditions in Romans 6?" NTS 29, no. 3 (1983): 339; Lars Hartman, "Into the Name of the Lord Jesus": Baptism in the Early Church (Edinburgh: T\&T Clark, 1997), 90-91.

${ }^{238}$ Søren Agersnap, Baptism and the New Life: A Study of Romans 6.1-14 (Aarhus: Aarhus University Press, 1999), 265.

${ }^{239}$ Eduard Stommel, “'Begraben mit Christus’ (Röm. 6,4) und der Taufritus,” RQ 49 (1954): 5; Tannehill, Dying and Rising, 34.

${ }^{240}$ Taylor, N. H. "Dying with Christ in Baptism: Issues in the Translation and Interpretation of Romans 6.3-4," BT 59, no. 1 (2008): 38-49. 
and the baptism ritual; the linkage of these two is made possible by argumentative inference from the preceding verse through the conjunction oṽv (therefore) in v. $4 .^{241}$

We have demonstrated that the foregoing baptismal allusions in Paul's corpus are denotative of ritual performance through three lines of evidence. The form analysis has enabled us to identify the possible baptismal tradition embedded therein even as we acknowledge that Paul has also left his own stamp on the tradition. The performative indicators help us go beyond the text to detect any ritual performance indicators behind the language of baptism. The metaphor predication allows us to look at the relationship between ritual and metaphor in a different light. Therefore, we now have from the various writings of Paul a complete baptismal text that is suitable for a ritual analysis. Granted, these baptismal texts, although we have isolated their pre-Pauline traditions, have already begun the process of imbuing theological interpretations of the ritual action, which could make it more difficult to decipher. However, we still can recover the ritual form and action from these layers of interpretations since one can have relative confidence in identifying a ritual action from a metaphor, such as the clothing metaphor, which alludes to the baptismal garment worn by candidates during the ritual. Furthermore, Paul's words appeared in the earliest stage of development of the baptism ritual, whose fuller sacramental theology would flower in the fourth century and beyond.

\subsection{Ritual Form}

Since the ritual background has been established, a reconstruction of the whole baptismal ceremony is necessary for the analysis of its ritual function. As these baptismal texts gathered from Paul's letters are fragmentary, we need to fill in some gaps by referring to the other baptismal texts in the New Testament. Before we proceed, there are a few caveats. First, the reconstruction of a full ritual apparatus is crucial to the understanding of the meaning of a ritual function, as those ritual elements are needed to explain the transformative aspects of the ritual performance. Second, we acknowledge that these reconstructions are plausible but not undeniable. Third, to the accusation of synthesising texts from different periods, we argue that - because the Pauline communities are part of the larger movement called the Jesus movement - one can draw on analogous practices from other Christ communities that share a common apostolic tradition. ${ }^{242}$ Thus, our references to other baptismal traditions outside of the Pauline

${ }^{241}$ Robert Jewett, Romans: A Commentary (Minneapolis: Fortress Press, 2007), 398.

${ }^{242}$ In his commentary on Leviticus, Jacob M. Milgrom uses a method of filling in the gaps by drawing analogies amongst parallel texts on the assumption that, if a certain action is required in ritual $\mathrm{A}$, then it may be required in ritual B: see Milgrom, Leviticus 1-16; Leviticus 17-22; Leviticus 23-27. 
corpus will venture no later than the third century. Moreover, ritual scholars like Gorman acknowledge that an imaginative construal is often required in ritual studies because one does not usually have access to full ethnographic descriptions. ${ }^{243}$ Fourth, we employ Grimes's schema of analysing ritual form by breaking down the form of the baptism ritual into seven elements: actions, actors, places, times, objects, languages, and groups. ${ }^{244}$ To answer any objection to using modern categories to read back onto the texts to find all seven elements of ritual form, I argue that a model is a heuristic tool that compels the serious scholar to acknowledge where the text does not fit the model. Moreover, all interpretations carry with them some kind of model or paradigm to understand the text. The important question is, "What new knowledge can this model generate, or does it hinder the generation of a new understanding of the text in question?

\subsubsection{Ritual actions}

The basic ritual action in baptism is the immersion in water. Beyond that, the whole ritual event, the plot of the action, goes from the movement of descent into ascent, as illustrated by the metaphorical language of Christ's death, burial, and resurrection. ${ }^{245}$ There are certain action languages associated with baptism that effect change in the participants: the language of divestment and donning a new cloth symbolising Christ's personality is formed in the participants (Gal 3:27; Col 3:9-10; Eph 4:22); ${ }^{246}$ the language of washing associated with the Spirit signifying the purification from $\sin (1$ Cor 6:11; Tit 3:5; cf. Acts 1:5; Heb 10:23), the language of new birth (John 3:3); the language of enlightenment indicating the illumination the participant receives regarding divine knowledge (Heb 6:4; 10:32); and the language of baptism itself, which saves the participant (1 Pet 3:21). Sometimes, the ecstatic speech accompanies the baptised emerging from the water, and Meeks suggests that the bilingual cry of abba may well have been one such utterance ( $\mathrm{Gal} 4: 6$; Rom 8:15-17). ${ }^{247}$ Often, the participants are passive in the ritual: they are being baptised and anointed by a human or sometimes divine agent. ${ }^{248}$ The

\footnotetext{
${ }^{243}$ Gorman, "Ritual Studies," 21; Walter Brueggemann, Texts Under Negotiation: The Bible and Postmodern Imagination (Minneapolis: Fortress, 1993).

${ }^{244}$ Grimes, Craft of Ritual Studies, 232-93.

${ }^{245}$ See baptism into Christ's death (Rom 6:3, 8; Cf. Rom 6:11; 2 Tim 2:11); buried with him in baptism (Rom 6:5; Col 2:12); and raised and made alive with Christ (Rom 6:11; Col 2:12; Eph 2:1; 2 Tim 2:11).

${ }^{246}$ See Geoffrey Wainwright, Christian Initiation, Ecumenical Studies in History 10 (Richmond, VA: John Knox Press, 1969), 14-15, and Wayne A. Meeks, The First Urban Christians: The Social World of the Apostle Paul, 2d ed (New Haven: Yale University Press, 1983), 151, 157.

${ }^{247}$ Meeks, First Urban Christians, 151-52.

${ }^{248}$ See Matt 3:11; Mark 1:8-9; John 1:26, 33; Acts 16:33; 19:5; 1 Cor 1:12-17.
} 
participants also recite the profession of faith, which involves calling on the name of Jesus. ${ }^{249}$ Finally, there is a period of intense preparation before the ritual involving instruction in the faith using a body of lore concerning the ritual and the larger mystery of that faith (Acts 18:26; Heb 6:2; Luke 1:4; Rom 6:1-11).

\subsubsection{Ritual actors}

The agents in the ritual are both divine and human. In the baptism narratives of Jesus, he receives baptism from John the Baptist, and act further confirmed by the voice of the father and the descent of the Spirit in the form of a dove (Matt 3:13-17; Mark 1:9-11; Luke 3:2123). ${ }^{250}$ In Acts, we see human agents are directly involved in the rite, which is often administrated by one of the apostles (Philip: Acts 8:35-39; Peter: Acts 10:44-48; Paul: Acts 19:1-7; Ananias: Acts 9:17-19); on other occasions, we see direct divine intervention as on the day of the Pentecost, when the apostles are baptised in the Holy Spirit (Acts 1:4-5). Although sometimes a divine agent is not directly involved in the enactment of the rite, we see divine involvement behind the scenes in the baptism of Paul and the Ethiopian eunuch (Acts 8:26-40; 9:10-21). In Paul's writings, the Holy Spirit is mentioned in tandem with baptism (1 Cor 12:13; cf. Titus 3:5), and the connection between baptism and the Spirit is prepared by John the Baptist, who speaks of the coming messiah baptising people in fire and the Spirit (Matt 3:11; Luke 3; cf. Acts 1:5). ${ }^{251}$

The disposition of the participants is also crucial to the rite. The participants must demonstrate fruits befitting eschatological repentance. On the day of Pentecost, Peter tells a crowd in Jerusalem that the phenomenon of speaking in tongues is a fulfilment of Joel 2, which prophesies that on the last day God will pour out his Spirit on all flesh. Peter then relates this

${ }^{249}$ Profession of faith: Acts 8:37 (v. 1.); 16:15, 31; cf. Rom 10:9; Invoking the name of Jesus: Acts 2:38; 4:12; 8:16; 9:14, 21; 10:43; 22:16; 1 Cor 1:2; 6:11. See Meeks, First Urban Christians, 152, and Joseph Crehan, Early Christian Baptism and the Creed: A Study in Ante-Nicene Theology (The Bellarmine Series 13; London: Burns, Oates \& Washbourne, 1950), 8-22.

${ }^{250}$ Everett Ferguson recognises that Jesus's baptism poses a tension between his baptism as sui generis, unprecedented and unrepeatable, and as a paradigmatic event for early Christian baptism practice. Nevertheless, the unique event of Jesus's baptism does provide a parallel to the promises of the Spirit and divine Sonship attached to baptism in the early Christian practice; see Everett Ferguson, Baptism in the Early Church: History, Theology, and Liturgy in the First Five Centuries (Grand Rapids: Eerdmans, 2009), 100.

${ }^{251}$ Some interpreters distinguish between water baptism and the Spirit in Paul's writings. This is exemplified by Dunn, Baptism in the Holy Spirit, in which he translates 1 Cor 12:13 as "submerged in the Spirit," and John R. W. Stott, Romans: God's Good News for the World (Downers Grove, IL: InterVarsity, 1994$), 173$. This distinction, however, goes beyond the evidence, as Douglas Moo observes that Paul often uses the verb $\beta \alpha \pi \tau i \zeta \omega$ to refer to water baptism (1 Cor 1:13, 14, 15, 16 [2x], 17; 12:13; 15:29; 1 Gal 3:27); see Douglas Moo, Romans 1-8: Wycliffe Exegetical Commentary (Chicago: Moody, 1991), 376. A more judicious view of the relationship between baptism and the Spirit would acknowledge that there is an actual ritual in the background and that the Spirit does play a role at baptism in mediating the effects thereof (cf. Acts 10:44-48). 
prophesy to Jesus's ministry, death, and resurrection. In other words, baptism relates to the coming of the messiah who inaugurates the last day that will usher in the kingdom of God. To be prepared for that kingdom, people would have to repent of their sins, accept Jesus as their messiah, and receive baptism, in which the gift of the Spirit is imparted as a pledge for the age to come.

Thus, we see the ritual agency involves a synergistic cooperation between divine and human agents. There is divine intervention in the form of the outpouring of the Spirit that fills the participants and human involvement in performing the rite through a proper disposition on the part of the participant.

\subsubsection{Ritual places}

The space in which the baptism ritual is carried out can be outdoor and indoor, public and private. Didache, in instructing on the administration of baptism, outlines three options for the kind of water one could use in administrating the rite, corresponding to the kinds of setting in which one is baptised: the running water $(7: 1)$, cold or warm water $(7: 2)$, and pouring water on the head (7:3).

The running water relates to the outdoor space where the candidates are baptised in the river. The book of Acts records four instances in which apostles preached to a crowd about the Christ message and were immediately baptised afterward (Acts 2:37-41; 8:5-13; 10:47-78; 16:13-15). Although the texts do not explicitly state that they were baptised in running water, there is a hint given by Acts 16:13-15 where it states "on the sabbath day we went outside the gate by the river" in verse 13 and later in verse 15 Lydia and her household was baptised. Thus, it is likely that Lydia and her household was baptised in the river mentioned in previous verse. This could apply to the other three instances where a considerable size of crowds was baptised in river. Moreover, there is an instance where baptism is administered in outdoor and is private in nature as in the case of Philip baptising an Ethiopian eunuch in an isolated place (Acts 8:36$38)$.

The other two kinds of water imply water taken from the spring that "still possessing its original "cool" temperature" or cistern that "no longer has its fresh temperature" and the water that is available at the disposal of the circumstance. These two kinds of water relate to indoor and private setting of baptism ritual. The book of Acts records two instances where baptism was administered in private setting and it was indoor, namely, the baptism of Paul (9:17-19; cf. 22:14-17) and of the jailer and his household (Acts 16:27-34). In both cases, the place in which the candidates were staying is indoor building, a private house. This suggests 
that the water used in these two instances were either taken from river or cistern or whatever water that was available at that moment. Additionally, it was possible that in both cases the water was poured over the candidates' head.

Finally, there are two recorded instances in Acts where the baptismal setting is uncertain. First is the baptism of a ruler of the synagogue, named Crispus "whose house joined hard to the synagogue" (Acts 18:5-8). This could suggest that either he and his family were baptised immediately in his private house after Paul preached Christ to them, or they were baptised in a pool in synagogue before an audience since the text immediately states that his house is joined to the synagogue and many Corinthians followed suite (these Corinthians could be proselytes or uncircumcised God-fearing gentiles). At the inception of the Christ religion, Pharisaic sages invented a prescribed mikveh, an immersion pool, even though its waters were still. ${ }^{252}$ Therefore, this would be a possible scenario in this case where both Crispus and his household and the Corinthians were baptised in a mikveh in the synagogue. Second is the baptism of certain disciples that Paul found in Ephesus (Acts 19:1-7). The text is silent on the setting of the baptism, but it offers a hint; that is, they only received into John's baptism. This implies that these disciples are Jews and thus were probably baptised in a pool at a synagogue.

Having outlined all the possible baptismal setting with the aid of accounts found in Acts, we now turn to the likely baptismal setting in Pauline communities. There are a few observations to be made. First, those Christ communities that Paul have had a share in founding it, such as Corinthian communities, gentile background. Second, these Christ communities meet in a private house or some private space and are often described as household of God (Rom 16:5; 1 Cor 16:15, 19; Eph 2:19-22; 1 Tim 3:14-15). Third, in many of these places where Pauline communities are located, such as Corinth, Galatia, Philipp, and so on, are metropolitan cities with many public bathhouses; some were used for cultic purposes in the cults of local deities and others were used for bathing. ${ }^{253}$ Based on these observations, we can say that the baptismal setting in Pauline communities are both public and private: either some were baptised in a private house or space where they normally gathered for worship or they took over a bath used for cultic activities. ${ }^{254}$ 66.

252 Jacob Neusner, “The Conversion of Adiabene to Judaism: A New Perspective,” JBL 83 (1964): 60-

${ }^{253}$ See DeMaris, New Testament in its Ritual World, 54-55.

254 The likelihood of Christ followers using these cultic baths for baptism can be deduced from the fact that Paul writes in 1 Corinthians that some participated in the temple sacrificial meal (8:7-13). This suggests that these Christ followers are still participating in the Graeco-Roman public life after joining Christ community. Paul admonishes them to refrain from certain areas of public life out of concern for the weak ones. 
In addition to the physical space in which the ritual is performed, there is a conceptual space in which baptism takes place. The phrase "baptised into Christ" denotes a mental sphere into which one is granted admission. In Ephesians 2:5-6, ${ }^{255}$ baptism transfers the believers from the earthly into the heavenly realm to be enthroned in heaven with Christ. In baptism, one not only attains a new life in Christ by transitioning from the old life to a new life but also shares in Christ's triumphal ascension to heaven, where the fullness of salvation is bestowed upon believers (Eph 1:3). ${ }^{256}$

\subsubsection{Ritual times}

There is no stipulation for a specific time at which baptism is to be performed. In most instances, baptism is performed during the day, apart from the instance in which Paul baptised a jailer late at night (Acts 16:25-33). This indicates that the baptism rite is not constrained by time and can be performed at any hour of the day. However, time's relationship with baptism is different according to its ritual logic. In baptism, the participants are connected in a special way with Christ's death and resurrection, which took place in the past. ${ }^{257}$ This Christ event is synchronised and brought before the candidates: baptism bridges the gap between the mythical past and present lives of the participants. ${ }^{258}$ Athanasios Despotis, in investigating Paul's concept of time regarding one's spiritual transformation and Christ event, observes that Paul uses the time schema once-now to refer to the timeline of salvation history (i.e. time prior to Christ event and time thereafter) and one's biographical history (i.e. pre-conversion and postconversion history). ${ }^{259}$ These two parallel timelines, Deposits further observes, can be synchronised during the conversion process, especially during the participation in the ritual life

255 Although baptism is not explicitly mentioned in this passage, the same scheme of dead-alive and oncenow that are associated with baptism appear in other Pauline writings (e.g., Rom 6 and Col 2:13). Tor Vegge surmises that Eph 2:5-6 is dependent in a literary sense on Col 2:13, which in turn based on the tradition in Rom 6: (1) the phrase "raised with Christ" (Eph 2:5) is a development of Col 2:12 and Rom 6:4-5; (2) the concept of buried with Christ which, along with the death of Christ, is an essential motif in baptism symbolism, is missing in Eph. 2:5; (3) there is a process of condensing the baptism tradition in Eph 2:5 in which the two-stage event of

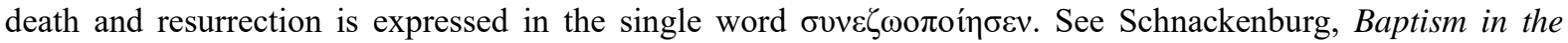
Thought, 73-78; Tor Vegge, "Baptismal Phrases in the Deuteropauline Epistles," in Ablution, Initiation, and Baptism: Late Antiquity, Early Judaism, and Early Christianity (ed. David Hellholm et al.; Berlin: De Gruyter, 2011), 525-27, and Nils Alstrup Dahl, Studies in Ephesians: Introduction Questions, Text- and Edition-Critical Issues, Interpretation of Texts and Themes, WUNT 131 (Tübingen: Mohr Siebeck, 2000), 413-40.

${ }^{256}$ Schnackenburg, Baptism in the Thought, 76-77.

${ }^{257}$ Neville Clark argues that baptism is a sacrament of inaugurated eschatology; the baptizands remain within the eschatological tension of already-but-not-yet; see "Initiation and Eschatology," in Baptism, the New Testament and the Church: Historical and Contemporary Studies in Honour of R.E.O. White, ed. Stanley E. Porter and Anthony R. Cross (Sheffield: Sheffield Academic Press, 1999), 337-49.

${ }^{258}$ Past divine acts are made present in rites or myths, and the present is understood in light of the past; see Eliade, Rites and Symbols, especially chapter 2.

${ }^{259}$ Athanasios Despotis, "Reconsidering the Pauline Conception of Time." JSPL 8 (2018): 20-42. 
of Christ community, since ritual enables the participant to participate in real time Christ's death and incorporation into Christ body. ${ }^{260}$

\subsubsection{Ritual objects}

The objects used in the baptism ritual include water, candles, chrism, and garments. We argue that some of these objects were already in use towards the beginning of second century, as attested in some of the late New Testament corpus. Living water, in most instances, is preferred, as in the case of Jesus's baptism, which is paradigmatic for his followers. However, the Didache, one of the earliest church manuals, allows for pouring water thrice over the head when sufficient water is not available (7:3).

Regarding the use of candle in the baptism ritual, it is difficult to determine whether an established custom use of candle for ceremonial purpose had been existed in the first two centuries of Christ movement. Nevertheless, the New Testament corpus hints at the use of lamp or candle at night when Paul and other Christ followers meet in an upper room for the preaching of the former (Acts 20:7-8). Note the in verse 7 the text says, "when we met to break bread

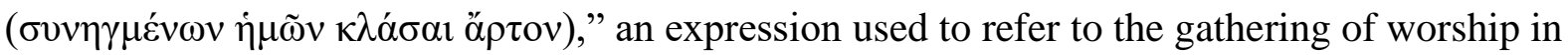
the early Christ movement (Acts 2:46; 1 Cor 10:16-17; 11:2-25). Then in verse 8 the text simply states that many lamps were lit in upstairs where they gathered. From this, we can observe that lamps or candles were lit when Christ followers gathered at night for a group worship, which includes ceremonies like baptism. This may well be for a practical use of lamps or candles to illuminate the place of gathering. Now it is difficult to establish whether candles were ascribed for some ceremonial meaning, like a garment that candidates would wear for baptism (Gal 3:27-28). Nonetheless, given light and fire serve as an important imagery in the theological imagination of early Christ movement, it is reasonable to assume that candles would eventually be ascribed a meaning of enlightenment and become an important part of baptismal rite (Rom 13:12; 2 Cor 4:4, 6; Eph 5:8-9).

The use of chrism is inferred from the anointing language (1 John 3:20; 3:27; Rev 7:3; Cf. Rev 22:4). ${ }^{261}$ In Pauline communities, anointing appears to have played a role in the baptismal liturgy, as hinted at by 2 Cor 1:21 ( $\chi \rho i ́ \sigma \alpha \varsigma$ ), which speaks of the time of the

${ }^{260}$ Despotis, "Reconsidering" 31-32.

${ }^{261}$ Gordon W. Lathrop describes several possibilities regarding the origins of the use of oil in the baptism ritual: "Anointing with oil at baptism might easily have followed from the name 'Christ,' from the explicit rejection of the old purity rules and from the sense that baptism into Christ was the new form of that old passive washing whereby priests were made (Exod 40:12-15; Lev 8:6-13) or that old prophetic metaphor in which Jerusalem was prepared to be married to God (Eph 5:26; cf. Ezek 16:1-14)"; see Gordon W. Lathrop, "The Origins and Early Meanings of Christian Baptism: A Proposal,"Worship 68, no. 6 (1994): 520. 
conversion of the Corinthians. ${ }^{262}$ Finally, the clothing metaphor connected with baptism suggests that the candidates would be clothed with a new garment after emerging from the water.

\subsubsection{Ritual languages}

Although the New Testament does not contain a complete baptism ritual text, it does contain diverse registers of ritual language. There is a Christ myth associated with the ritual of baptism, as Paul links the Christ event with that of participation in baptism ritual (Rom 6; cf. 1 Cor 15:341; Col 2:13). The Christ myth works together with the baptism ritual. There are baptismal formulae scattered throughout Paul's letters, most of which are direct quotations from the baptism liturgy, as we have seen in the previous section. There is also recitation of some form of creedal statement relating to the kerygma. ${ }^{263}$ Finally, there is ecstatic utterance accompanying baptism as the participant is filled with the Spirit, most likely in the form of the $a b b a$ cry.

\subsubsection{Ritual groups}

The social dynamics of the baptism ritual speaks of its counter-cultural value and the worldview of the day. Baptism subverts the social distinctions that prevailed in the ancient Mediterranean world by eliminating its triple social stratifications: Jewish/Greek, free/slave, and male/female (Gal 3:23-24; cf. 1 Cor 12:13; Col 3:10-11). As result, neophytes are incorporated into a new society and become members of a living organism, Christ's body, whose head is Christ (1 Cor 12:13-14). Baptism rejects certain vices that were prevalent at the time and upholds certain virtues in the lives of Christ followers (1 Cor 6:9-10; Gal 5:19-24; Rom 6:8-10). Finally, baptism challenges the political and cultural norms of the Greco-Roman world regarding the use of water. By practicing baptism once instead of multiple times, as in Greco-Roman ablutions, and the use of flowing water instead of collecting water through the activity of human hands, Christ followers subtly challenge the hegemony of Roman rule expressed through the control of water; ${ }^{264}$ by defining washing symbolism as an identifying

${ }^{262}$ G. W. H. Lampe. The Seal of the Spirit: A Study in the Doctrine of Baptism and Confirmation in the New Testament and the Father, 2d ed. (London: SPCK, 1967), 61-62.

${ }^{263}$ In Early Christian Baptism, Joseph Crehan distinguishes between two of the earliest creedal formulae in Christ communities: the Trinitarian formula in Matt 28 and the name formula ("in the name of Jesus Christ") in Acts. The former is used in administering baptism, and the latter is used by the candidate as a confession of faith in Jesus; see Crehan's chapter on the "Baptism in the Name."

${ }^{264}$ See Choi, "Boundary-Crossing," 75-91, and DeMaris, New Testament in its Ritual World, 37-56. 
practice for the entry into the Christ assembly, which proclaims God's grace in Christ, Christ followers alter the cultural washing symbolism to suit their own purposes. ${ }^{265}$

This form analysis of baptism ritual results in the recovery of baptism as a complete ritual with all the details and complexities that accompany an initiation ritual. ${ }^{266}$ Granted, some details outlined above may be subject to accusations of temporal anachronism. However, as we have noted in chapter one, no ethnography is complete in documenting all the details of a ritual from all perspectives, and this is no less true of baptism in nascent Christianity. What we possess is a fragmentary account of the ritual diffused through various writings in the New Testament. Thus, it behoves us to reconstruct the ritual imaginatively based upon this textual evidence, supplemented by the method of filling in gaps from the parallel texts.

\subsection{Ritual Context}

Before commencing the ritual analysis of baptism, we need to consider the wider context in which the baptism ritual was located socially and culturally, which will help us understand the overall function of performing the baptism ritual. We argue that the social context of the baptism ritual in Christ movement is an issue of orthodoxy. A failure in the correct articulation of the symbolic material encoded in the ritual would result in a failure of the ritual performance and its efficacy. ${ }^{267}$ As to the cultural aspects of the ritual context, I argue that, broadly speaking, rituals in Mediterranean religions exhibit the motifs of perfection, purification, eschatology, and transformation that contribute to an overall salvific experience for the participants. The baptism ritual incorporates those motifs in its ritual performance as frames of reference that seek to transform the participants.

\subsubsection{Social context}

As we note in a later section, the performance of ritual brings about an emergence or reality that depends on the performative authority and the way the ritual structure is articulated within

${ }^{265}$ Lathrop, "Origins and Early Meanings," 504-22.

266 Agersnap (Baptism, 297n129) argues that the mystery rites are incongruous with Rom 6 because the former involve a long ritual process through many agents, whereas the latter is a momentary ritual process whose religious experience cannot be accommodated in the acts of immersion and emersion, and criticises Meeks's reconstruction of the baptism ritual as having a "hypothetical stamp." Two points may be offered in rebuttal. First, the claim that the baptism ritual in nascent Christianity is a momentary process is itself an assumption. Agersnap cites Rom 6:3-8's concise description of the baptismal act as evidence for the momentary process of baptism with a single agent. However, Paul here is alluding only to a crucial moment in the baptism ritual; namely, the act of immersion and emersion as it pertains to his argument. The whole apparatus of the ritual experience must be more encompassing than just this one ritual moment. Second, based on the reconstruction of the baptismal form outlined above, which is grounded in textual evidence, we have every reason to believe that multiple agents were involved in the ritual, including the main administrator of the rite the servers assisting in clothing the neophytes, and an extended ritual process encompassing catechetical preparation and the actual participation in the rite.

${ }^{267}$ Schieffelin, "On Failure and Performance," 81. 
a social reality. For now, we are concerned with the articulation of ritual structure in social reality. One way in which baptism articulates its ritual structure is through a public confession of the credo regarding the Christ event. We have noted that creed is one register of the ritual language that forms baptism's ritual text. I propose that Paul's use of baptismal language is interwoven with early credal statements, as Paul wants to ensure that the embodiment of the kerygma is present in the lives of his readers through the baptism ritual.

As Bell observes, the rituals in orthodoxic traditions "are frequently concerned with avowing theological ideas and creedal statements." 268 Paul's use of baptismal language is concerned with kerygma and its implication for living in accordance therewith; ${ }^{269}$ the clearest example is Rom 6:1-11. We have seen above that the baptismal formula in Rom 6:3-8 contains a credo statement echoed by 1 Cor 15:3-5. Having explained the significance of the baptism ritual in light of the kerygma, Paul immediately links it with the language paraenesis through

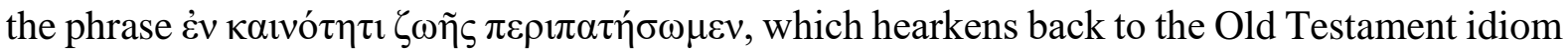
of proverbially walking "in the law/statues/ordinances/ways of God." In other words, having identified with Christ in baptism, Christ followers should now lead a conscious life untainted by sins and passions of the flesh. This new life identifies with the risen Christ and is a continuous process, indicated by the verbal aspect of $\pi \varepsilon \rho ı \pi \alpha \tau \tilde{\sigma}^{\sigma} \sigma \omega \mu \varepsilon \mathrm{v}$, an aorist ingressive. ${ }^{270}$ Paul also links $\pi i ́ \sigma \tau ı \zeta$ with $\beta \alpha \pi \tau i \zeta \varepsilon ı v$ in Gal 3:26-27. Turley has pointed out the grammatical connection between the two:

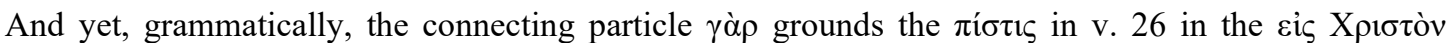
$\dot{\varepsilon} \beta \alpha \pi \tau i \sigma \theta \eta \tau \varepsilon$ reference in $v$. 27a, with the ó $\rho \alpha$ in v. 29 drawing out the inference from these premises. Thus, v. 26 appears to ground their soteriological status as "sons of God" in $\pi$ í $\tau \imath \iota \varsigma$, whilst v. 27a appears to ground that status in their baptisms. ${ }^{271}$

268 Bell, Ritual Perspectives and Dimensions, 194.

${ }^{269}$ In addition to concerns with the correct understanding of the kerygma, Paul also gives a considerable space to the implications of Christian living or one's response to the gospel in his letters. For instance, Paul uses

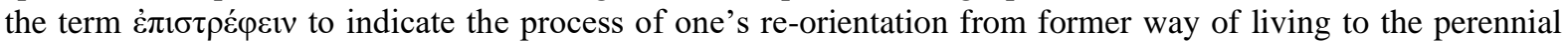
ontological transformation of the self, fashioned after the image of God ( $\mu \varepsilon \tau \alpha \mu \rho \rho \varphi о \tilde{\sigma} \sigma \theta \alpha 1,2$ Cor 3:16-18). For Paul to accept and turning to Christ entails both the embracing a whole new outlook to life and the existential transformation and socialisation in Christ's body, the ekklesia. Since the transformation of the self in Christ occupies much of Paul's thought in his letters, some label Pauline Christianity as "conversionist type of religion." See Athanasios Despotis, "From Conversion in Paul and 'John' to Theosis in Their Patristic Reception," HBT 38 (2016) 88-109.

\footnotetext{
270 Joseph A. Fitzmyer, Romans: A New Translation, with Introduction and Commentary (New York: Doubleday, 1993), 434-35.

271 Turley, The Ritualized Revelation, 38.
} 


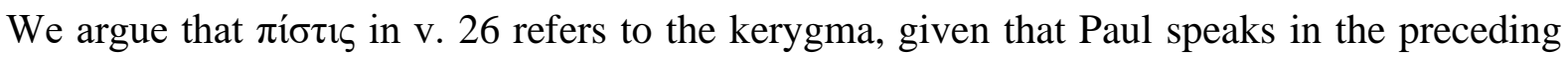
verses (23-24) of the revelation of $\pi$ í $\tau \imath \varsigma \varsigma$ and Christ prior to the Galatians' adoption into divine

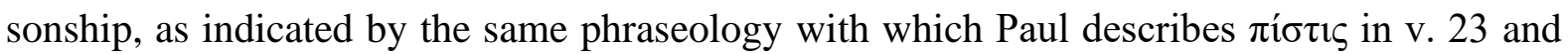

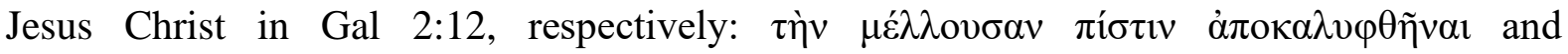

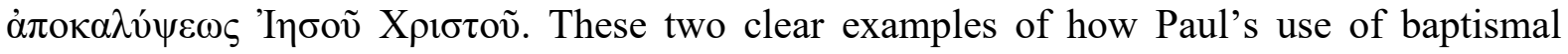
language relates to the kerygma of the early church, which was most likely publicly recited at baptisms, intimate that Paul expects his readers to live according to the new reality that they have experienced at baptism. According to the ritual logic, those who have received baptism would be new creations, and dissonance between that which is experienced at baptism and life post-baptism would signal that the baptism ritual had failed to bring about the new emergence in social reality that was expected of it.

Pheme Perkins argues that the concern for doctrinal orthodoxy is a late second-century development, noting that Christ association, like other private cult associations, is not so much concerned with ritual knowledge as with administrative aspects of the cult, and there is little correlation between ritual activities and textual interpretation. ${ }^{272}$ Whilst nascent Christ association exhibits certain traits that are similar to a private cult association, there is no textual evidence supporting the claim that the Christ movement privileges ritual activities over imparting the body of knowledge. In fact, the opposite is true. Although one must, of course, be cautious about linking synagogue worship with early Christian reading and preaching, Andrew B. McGowan observes that there are various forms of oral contributions to the meal setting at worship. ${ }^{273}$ Examples include reading one of Paul's letters as it was intended. Furthermore, the Christ religion is steeped in the textual tradition, just as Judaism is, as shown by Paul's Midrashic interpretation of Hebrew scriptures' being fulfilled in the person and works of Christ. Second, Perkins makes a sharp distinction between ritual activities and textual interpretation. That various baptismal formulae are incorporated into Paul's letters to suit his purposes and that these same letters were later read at the gathering of Christ followers for worship attests to the interdependence of ritual activities and textual hermeneutics in the early Christ movement, not to any cleavage between the two.

\footnotetext{
272 Pheme Perkins, "Ritual And Orthodoxy," in The Oxford Handbook of Early Christian Ritual, ed. Risto Uro et al. (Oxford: Oxford University Press 2019), 504-05.

273 Andrew B. McGowan, Ancient Christian Worship: Early Church Practices in Social, Historical, and Theological Perspective (Grand Rapids: Baker Academic, 2014), 55-61.
} 


\subsubsection{Cultural context}

For the cultural aspect of the ritual context, we focus on the religious practice of initiation rites in Greco-Roman mystery cults and the Jewish apocalyptic sect in Qumran. As the Christ movement emerged from these two cultural and religious milieus, it took up motifs from both: transformation, perfection, eschatology, and purification.

The motif of transformation is present in the Isis ritual, as is seen in the language of death and rebirth and identification with Osiris. Lucius recounts his experience of his first initiatory rite into Isis as "in the manner of a voluntary death" and as "approa[ching] the boundary of death." The reference to ritual death alludes to the journey through the underworld Lucius was taking in the ritual. The Egyptians believed that the Sun god resides in this realm, and a deceased soul goes to accompany the Sun god in its daily encircling of heaven, earth, and the underworld. ${ }^{274}$ The deceased soul experiences rejuvenation and rebirth at dawn. Jan $\mathrm{N}$. Bremmer suggests that the language refers to the power of Isis over death and life, citing the inscription at Bithynia, in which an initiate recounts that he has "run to the haven of the blessed one." ${ }^{275}$ The language of new birth pervades Apuleius's account of the Isis initiatory ritual. The Isis-cult priest explains to Lucius that his noble birth avails him nothing, but a new birth through initiation into Isis will grant him a new life, passing from the transient whims of Fortuna to the benevolent rule of Isis $(11.15,16)$. The initiatory new birth is brought about by Isis and the presiding priest who serve as Lucian's spiritual parents (11.25). Another aspect of transformation afforded by the Isis cult is the identification with Osiris. Some scholars, when discussing the relation of Rom 6 to the Isis cult, dispute the claim that the language of identification exists in the cult. ${ }^{276}$ Turning to the various mythologies of the Greco-Roman period, Brook W. R. Pearson discovers two elements: the aetiological myth of the Orphic mysteries has the son of Zeus or Zagreus, and the aetiological myth of the slaughter and rebirth of Zagreus is closely linked with that of Isis and Osiris cycle. ${ }^{277}$ The ancient form of the IsisOsiris mystery cult identifies the king with the god, and the myth would remain the same as it spread throughout the Greco-Roman world, which is confirmed by Plutarch's discussion of the story (360F, LCL).

${ }^{274}$ Apuleius of Madauros, The Isis-Book (Metamorphoses, Book XI), ed. J. Gwyn Griffiths (Leiden: Brill, 1975), 297.

275 Jan N. Bremmer, Initiation into the Mysteries of Ancient World (Berlin: De Gruyter, 2014), $121 \mathrm{n} 66$.

276 James D. G. Dunn, Word Biblical Commentary: Volume 38A, Romans 1-8 (Waco, TX: Word Books, 1988), 310; Wedderburn, "Hellenistic Christian Traditions," 345; A. J. M. Wedderburn, "The Soteriology of the Mysteries," NovT 29, no. 1 (1987): 57-72.

${ }^{277}$ Brook W. R. Pearson, "Baptism and Initiation in the Cult of Isis and Sarapis," in Baptism, the New Testament and the Church: Historical and Contemporary Studies in Honour of R. E. O. White ed. Stanley E. Porter and Anthony R. Cross, JSNTSup 171 (Sheffield: Sheffield Academic Press, 1999), 52-54. 
The motif of religious perfection is conspicuous in these two mystery cults by the multiple stages of initiation. Lucius is first initiated into the mysteries of Isis, but he soon realises that there is a higher grade of initiation, which implies the incompleteness of the first rite, which is supported by the phrase "had not yet been enlightened by the mysteries of the ... unconquered Osiris" (11.27). Only after Lucius has undergone the third initiatory rite is he assured of joy, happiness, and salvation (11.29). Thus, we can clearly see three degrees of initiation: 1) initiation-purification (the initiation into Isis is preceded by a purification rite); 2) illumination, communion or communication with Osiris; and 3) happiness resulting from communion with Isis-Osiris. The multiplicity of the initiatory ritual is even more manifest in Eleusis's mystery cult, which featured well-defined multiple initiations with initiation ( $\mu v ́ \sigma \tau \eta \varsigma)$,

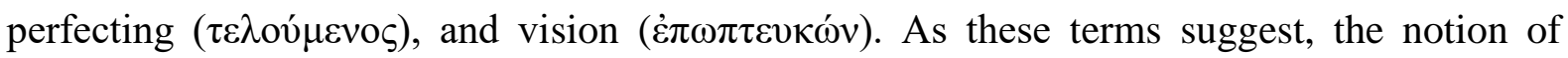
religious perfection was inherent in the ritual. The term $\mu$ v́ $\tau \varsigma \varsigma$ signifies ritual blindness in the first stage of the mystery's initiation rite. At the end of that stage, the participant is called

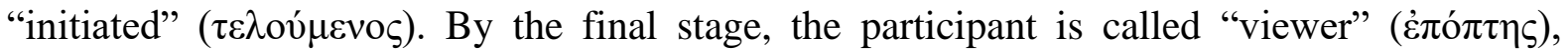
beholding the divine presence in the form of light. The movement is from epistemological blindness to the enlightenment of divine knowledge at the end of the ritual.

The eschatology motif is present in the Eleusinian mystery as it relates to the individual's life after death. In the Homeric Hymn to Demeter, the poet describes the immortality is granted to the initiated ones:

Blessed is he of men on earth who has beheld them, whereas he that is uninitiated in the rites, or he that has no part in them, never enjoys a similar lot down in the musty dark when he is dead. ${ }^{278}$

Some scholars have downplayed the eschatological aspect of the Eleusinian cultic ceremonies. Hugh Bowden argues that the cult is not so much concerned with the afterlife as it with the transformative experience one has in contact with gods. ${ }^{279}$ This view is hardly convincing since other texts of the same genre express belief in the afterlife. For instance, Pindar, frag. 121 Bowra: "Blessed is the one who has seen this before descending below. He knows the end of life, and also knows the beginning given by the gods"; and Sophocles, frag. 837 Radt: "Thrice blessed are those mortals who have seen this consecration and then go to Hades. For them alone is life there, but for the others everything is ill." Bremmer points out that the actual performance of the Eleusinian mysteries does not mention the afterlife but does refer to agricultural

\footnotetext{
${ }^{278}$ Hom. Hymn Dem. 470-82, in Homeric Hymns, Homeric Apocrypha, Lives of Homer, trans. Martin L. West, LCL 496 (Cambridge: Harvard University Press, 2003).

${ }^{279}$ Hugh Bowden, Mystery Cults in the Ancient World (London: Thames \& Hudson, 2010), 47-48.
} 
fertility. ${ }^{280}$ Christiane Sourvinou-Inwood has shown that, in its pre-mystery form, the Eleusianian ceremony had been an advent festival structured through an advent schema designed to renew the relationship between Demeter and her worshippers. ${ }^{281}$ Over the centuries, further semantic layers were added to this advent festival until the mystery discourse was created. ${ }^{282}$ The performance of the mysteries acquired the notion of divine advent, as shown in the arrival of the hiera at Eleusis. ${ }^{283}$ Thus, the eschatological aspect of the performance manifests itself through the overarching initiatory participation in the divine advent schema aiming at the attainment of a more elevated status in the afterlife.

Finally, the motif of purification pervades both mystery cults and the Jewish rite of immersion. In the former, purification serves as a preparatory rite an appropriate state to be initiated into the mysteries. The means of purification is normally water; sometimes other objects, like a fan or a torch, are involved (see Hymn to Demeter). In mystery cults, the ablutions serve as purification from sin and a prerequisite for the mystery proper (11.23), whose aim is to remove any pollution or impurity from participants before they can gain access to the sacred realm. The purification rite in mystery cults involves multiple ablutions on a regular basis. While water is the sole material means of the purification rite, on a spiritual level these ritual texts speak of purification by God's law (4Q414 Frgs. 2 Col. ii, 3, 4). The impurity concept presented in the Qumran texts represents a new development of the concept of defilement in which human beings are no longer powerless against the effects of the impurity of $\sin$ but have the means to rectify their miserable reality. Yair Furstenberg calls this "the reification of moral impurity, i.e., the embodiment of this impurity in tangible objects, which could be disposed of and purified." 284 The result of this process of reification is the blurring of the distinction between physical and moral purity, whereby the ritual categories of impurity are applied to contiguous objects to capture moral impurity within the overall framework. Moreover, the reification of moral impurity applies to sin imparted by demons. The reification of sin as internal impurity facilitates the removal thereof through incantations and prayers. ${ }^{285}$

${ }^{280}$ Bremmer, Initiation into the Mysteries, 18-19.

${ }^{281}$ Christiane Sourvinou-Inwood, "Festival and Mysteries: Aspects of the Eleusinian Cult," in Greek Mysteries: The Archaeology and Ritual of Ancient Greek Secret Cults, ed. Michael B. Cosmopoulos (New York: Routledge, 2003), 25-41.

${ }^{282}$ Sourvinou-Inwood, "Festival and Mysteries," 37.

283 Ibid., 37-38.

${ }^{284}$ Yair Furstenberg, "Initiation and the Ritual Purification from Sin: Between Qumran and the Apostolic Tradition," DSD 23, no. 3 (2016): 370.

${ }^{285}$ See David Flusser, "Qumran and Jewish Apotropaic Prayers," in Judaism and the Origins of Christianity (Jerusalem: Magnes, 1988), 214-25; M. Kister, "Demons, Theology and Abraham's Covenant (CD XVI, 4-6 and Related Texts)," in The Dead Sea Scrolls at Fifty: Proceeding of the 1997 SBL Qumran Section Meetings, ed. R. A. Kugler and E. M. Schuller (Atlanta: Scholars Press, 1999), 167-84; and E. Eshel, "Apotropaic 
This discussion of ritual context has situated the baptism ritual in the social and cultural environment in which it was performed and contributes to our understanding of its ritual meaning. The social context of the ritual involves the transmission of doctrine through ritual activities to impress on the participants the complex worldview entailed therein. The cultural context of ritual is steeped in the common landscape of religious phenomena, sharing in common motifs and themes that offer people a path to spiritual transformation and salvation.

\subsection{Ritual Function}

In previous sections, we have laid the groundwork for ritual analysis by establishing the baptismal texts, reconstructing the baptism ritual elements, and placing the ritual in its early social and cultural context. Thus, we can now perform a ritual analysis of these reconstructed texts using the performance approach. Before we proceed, a few remarks on the use of ritual performance theories are in order. First, as noted in chapter one, choosing this school of ritual theories has the advantage of explaining the process and manner in which transformation takes place in a ritual performance, as opposed to the symbolic approach to ritual, which sees rituals as a special language to be decoded. Second, we have suggested to that end a working definition for ritual performance that includes the following elements: agency, entailment, virtuality, emergence, and relationality. Using this matrix of ritual functions as a heuristic tool, we shall demonstrate how the baptism ritual evinces of these elements and note where the text does not fit. Each ritual function is akin to a piece of a jigsaw puzzle that contributes to the whole picture of transformation facilitated by and through ritual performance.

\subsubsection{Agency}

Drawing on Lawson and McCauley's theory that religious rituals follow the general pattern of any action in which agents are doing something to somebody through an instrument, we focus on the two principles that underline the superhuman agent in the theory. First, the principle of superhuman agency involves the "character of the superhuman agent's involvement in the ritual." ${ }^{286}$ The more actively the superhuman agent is implicated in the ritual, the more central the ritual is to the religious system in question; conversely, the more passive the superhuman agent is in the ritual, the less important the ritual is to the religious system. ${ }^{287}$ Second, the

Prayers in the Second Temple Period," in Liturgical Perspectives: Prayer and Poetry in Light of the Dead Sea Scrolls, ed. E. G. Chazon (Leiden: Brill, 2003), 69-88.

${ }^{286}$ Lawson and McCauley, Rethinking Religion, 125.

${ }^{287}$ Ibid., 125. 
principle of superhuman immediacy states that the fewer enabling actions implicate the superhuman agent in the ritual, the more foundational the ritual is to the religious system. Thus, in a religious system where the superhuman agent is heavily implicated in ritual actions, the superhuman agent is more fundamental to the religious system than one where the role of the superhuman agent is largely embedded in the structural description. ${ }^{288}$ These two principles underscore the concern for the success of religious ritual, which requires the cooperation of the gods. ${ }^{289}$ In reverse order, we shall discuss the role of the Spirit as a superhuman agent in baptism.

The immediacy of the Spirit in the baptism ritual can be seen in the prepositions used in conjunction with the Spirit. The basic Greek construction is $\dot{\varepsilon} v \pi v \varepsilon v ́ \mu \alpha \tau \iota \beta \alpha \pi \tau 1 \sigma \theta \eta \dot{\sigma} \sigma \varepsilon \sigma \theta \varepsilon$ (1 Cor 12:13; Acts 1:5; 11:15-16; Luke 3:16; John 1:33). These passages show that the Spirit is not directly involved as an agent, appearing only in "embedded, enabling action that has occurred previously. $" 290$ Two observations can be made. First, the Spirit as an enabling action has appeared previously; when Jesus was baptised, the Spirit descended on Jesus from the Father (Matt 3:13-17; Mark 1:9-11; Luke 3:21-23). This same Spirit also descended on Jesus's disciples after his death and resurrection on Pentecost, which inaugurates the general outpouring of the Spirit. ${ }^{291}$ The nature of the bestowing of the Spirit on Jesus at his baptism and on his disciples at Pentecost are distinct: the former is the fulfilment of the Old Testament expectation of the Messiah, whereas the latter is the outpouring of the Spirit by Jesus in his exalted state, signifying the establishment of Jesus's status as Messiah. ${ }^{292}$ Second, the phrase $\dot{\varepsilon} v \pi v \varepsilon v ́ \mu \alpha \tau \imath$ $\dot{\beta} \beta \alpha \pi \tau i ́ \sigma \theta \eta \mu \varepsilon v$ in 1 Cor 12:13 should be understood as having an instrumental sense: baptised by means of the Spirit. ${ }^{293}$ This rendering is supported by two contextual clues. The

${ }^{288}$ Ibid., 125-26.

${ }^{289}$ Ibid., 125.

${ }^{290}$ Ibid., 126.

${ }^{291}$ Lampe, The Seal of the Spirit, 41.

292 Macaskill, Union with Christ, 198. Macaskill cautions that, whilst one can speak of analogies between Spirit-baptism at Jesus's baptism and his disciples, there should not be a simple equating of the two, especially in the understanding of the Spirit's role as constitutive of Jesus's divinity at his baptism in the River Jordan. See Heinrich von Baer, Der Heilige Geist in den Lukasschriften (Stuttgart: W. Kohlhammer, 1926); Hermann Gunkel, Die Wirkungen des Heiligen Geistes: Nach der populären Anschauung der Apostolichen Zeit und der Lehre des Apostels Paulus: Eine biblisch-theologische Studie (Göttingen: Vandenhoeck \& Ruprecht, 1899); and Dunn, Baptism in the Holy Spirit, 23-37.

293 There are three views on the meaning of baptism with/by the Spirit. The first view sees water-baptism as in view and links the reception of the Spirit with baptism in water. See, e.g., F. F. Bruce, 1 and 2 Corinthians, NCBC, (Grand Rapids: Eerdmans, 1971); John R. W. Stott, Baptism and Fullness: The Work of the Holy Spirit Today, 2d ed. (Downers Grove, IL: InterVarsity Press, 1975). The second view sees spirit-baptism as an initiatoryconversion that is distinct from water-baptism. See, e.g., Dunn, Baptism in the Holy Spirit, and Ralph. P. Martin, "Patterns of Worship in New Testament Churches," JSNT 37 (1989): 59-85, especially 71. The third view holds that both spirit and water baptism use the concept of synecdoche, with a part standing for the whole. See Anthony R. Cross, "Spirit- And Water-Baptism in 1 Corinthians 12.13," in Dimensions of Baptism: Biblical and 
use of $\dot{\varepsilon} v$ with $\pi v \varepsilon \tilde{v} \mu \alpha$ occurs once in v. 3 and twice in v. 9, where the instrumental sense is present. ${ }^{294}$ In vv. 4-11 the bestowal of the charismatic gifts is imparted by God through the operation of the Spirit. Schnackenburg observes that there is a kyrios-pneuma notion in the passage, with the pneuma imparting various gifts according to its disposition, which corresponds to that of Kyrios. ${ }^{295}$ In other words, the Kyrios works through Pneuma in all the charismata. This close association of Kyrios with Pneuma is apparent in the Gospel of John, where the Pneuma will continue the Kyrios' ministry after his departure to the Father and the resurrected Jesus breathes the Spirit into the disciples (John 14:26; 20:21-23). Furthermore, Porter in his Idioms of the Greek New Testament lists three kinds of "specified agency," one of which is instrumental or impersonal agency "using $\dot{\varepsilon} v+$ dative or the simple dative case."296 All the passages containing the "Eे with $\pi v \varepsilon \tilde{v} \mu \alpha$ " construction with baptism fit into this category (Luke 3:16; John 1:33; Acts 1:5; 11:16). ${ }^{297}$ Therefore, whilst the Spirit is active in baptism in some capacity, its action is embedded within the ritual structure as accompanying the rite whose primary agent is the risen Lord who sends the Spirit to the disciples.

The character of the Spirit's involvement in the baptism ritual is the perfection of the rite, which is achieved by infusing the effects of baptism into the participants. There are two lines of evidence to support this. First, the elements of Spirit and water are indispensable in the entire process of initiatory experience. This is physically expressed in the laying on of hands (Acts 8:4-20; 19:1-7; Heb 6:1-6). ${ }^{298}$ Both passages in Acts $(8: 4-20 ; 19: 1-7)$ show that the conversion experiences of these Christ followers are not complete until they receive the Spirit through the laying on of hands. The passage in Hebrews (6:1-6) distinguishes the doctrine of

Theological Studies, ed. Stanley E. Porter and Anthony R. Cross, JSNTSup 234 (Sheffield: Sheffield Academic Press, 2002), 120-48.

${ }^{294}$ Howard M. Ervin, Conversion-Initiation and the Baptism in the Holy Spirit: A Critique of James D. G. Dunn, Baptism in the Holy Spirit (Peabody, MA: Hendrickson, 1970), 99.

${ }^{295}$ Schnackenburg, Baptism in the Thought, 27-28.

296 Porter, Idioms, 64-65.

${ }^{297}$ See Matthew Brook O’Donnell, “Two Opposing Views on Baptism with/by the Holy Spirit and of 1 Corinthians 12.13: Can Grammatical Investigation Bring Clarity?" in Baptism, the New Testament and the Church: Historical and Contemporary Studies in Honour of R.E.O. White, ed. Stanley E. Porter and Anthony R. Cross, JSNTSup 171 (Sheffield: Sheffield Academic Press, 1999), 330-33, which catalogues all verses containing the construction and $\beta \alpha \pi \tau i \zeta \omega$ in passive form. O'Donnell concludes that "it has been demonstrated that the preposition $\dot{\varepsilon} v$ accompanied by $\pi v \varepsilon u ́ \mu \alpha \tau \iota$ is often used to signify personal agency." However, he ignores the fact that those verses that explicitly contain $\dot{\varepsilon} v \pi v \varepsilon v ́ \mu \alpha \tau \imath \beta \alpha \pi \tau \iota \sigma \eta \dot{\sigma} \sigma \varepsilon \theta \varepsilon$ have an instrumental sense, since verses containing only $\dot{\varepsilon} v \pi v \varepsilon v ́ \mu \alpha \tau$ might not be a reference to baptism; hence, the comparison is irrelevant.

${ }^{298}$ Whether there is an actual rite accompanying the bestowal of the gifts of the Spirit has been debated by scholars. As an example of those who see a rite behind the laying on of hands, see Thomas Marsh, Gift of Community: Baptism and Confirmation (Wilmington, DE: Michael Glazier, 1984). Representing those who does not see a separate rite in it are Frank Quinn, "Confirmation Reconsidered: Rite and Meaning," Worship 59 (1985): 354-70, and Maxwell E. Johnson, The Rites of Christian Initiation: Their Evolution and Interpretation (Collegeville, MN: The Liturgical Press, 1999), 25-26. 
the ablution act and the laying on of hands. Moreover, Paul himself includes the reception of the Spirit as part of the whole initiatory experience of the participant in conjunction with waterbaptism. The passages in 1 Cor $(6: 11 ; 12: 13)$ speak of the Spirit as coordinate in the act of immersion, indicated by the parallel terms "in the name of the Lord Jesus Christ and in the

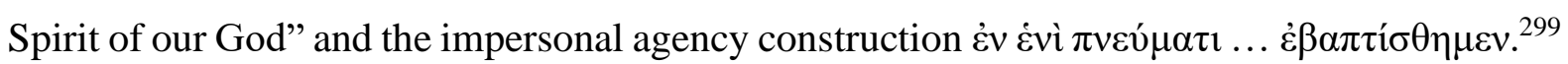
The passage in Gal 3:1-5 recalls the beginnings of the faith when the Galatians received the Spirit, an allusion to their initiation experience. In v. 5, Paul connects the Spirit with the mighty deeds: the charisms imparted to the community at baptism. ${ }^{300}$ For this reason, Paul is adamant that the Galatians should not undergo a second initiation rite, the rite of circumcision. Second, the same effects spoken of baptism is also spoken of the Spirit when it descends on a person; in other words, the Spirit mediates the effects of baptism for the participants.

Effects

\begin{tabular}{|l|l|l|}
\hline Water baptism & Cleansing & Clothing \\
\hline Spirit & Washing and regeneration & Clothing \\
\hline
\end{tabular}

The most basic effect of water-baptism is cleansing; the same applies to the Spirit in 1 Cor 6:11, where the washing is also done in the name of the Spirit. The Gospel of John develops the close connection between flowing water and the Spirit in terms of providing the spiritual birth from above and the living water that flows from within promised by Jesus $(3: 5-8 ; 7: 37-39$; cf. 4:715). The writer of Titus espouses the same notion that the Spirit affects a regeneration associated with water imagery (Tit 3:5). Another effect of baptism is to be clothed with Christ (Gal 3:27-28). The same is said of the Spirit in Luke 24:49, in which Jesus's disciples are instructed to wait for the power from on high, which is the Spirit, a promise Jesus made to them on the night he was betrayed. Interpreters often understand the phrase "putting on Christ" as meaning union with Christ; likewise, one can understand the language of "clothed with the Spirit" as union with the Spirit at baptism, as evident in Paul's language of fellowship with and the indwelling of the Spirit (2 Cor 13:14; Rom 8:9, 26-27; Phil 2:1-2; cf. John 14:16; 16:13; 1 John 1:3).

\footnotetext{
${ }^{299}$ Kilian McDonnell and George T. Montague, Christian Initiation and Baptism in the Holy Spirit: Evidence from the First Eight Centuries, 2d ed. (Collegeville, MN: The Liturgical Press, 1994), 42-47.

${ }^{300} \mathrm{McD}$ onnell and Montague, Christian Initiation, 47.
} 


\subsubsection{Entailments: Myth and sacred discourse}

Rappaport defines ritual as a performance whose form and structure are relating to one another. ${ }^{301}$ Within this structural relation are the logical entailments that entail, amongst other things, "the representation of a paradigm of creation" and "the generation of the concept of the sacred and the sanctification." ${ }^{302}$ In the former, a ritual involves a myth that accompanies it; in the latter, a ritual engenders the concept of purity relating to sacred things. The baptism ritual entails both elements: the re-enactment or re-presentation of the creation and Christ myths and the purification of the participant. We begin with the myths accompanying the baptismal rite.

Mircea Eliade defines initiation as "a body of rites and oral teachings whose purpose is to produce a decisive alteration in the religious and social status of the person to be initiated." ${ }^{\prime 303}$ The initiands are inducted into or taught a body of mythical traditions that Eliade describes as a "conception of the world" that is passed down from one generation to the next. This set of traditions consists of the story of the creation of the world by supernatural beings, the advent and cultural activities of a mythical ancestor, and their disappearance. This sacred history lays the foundation for all subsequent human behaviours and all social and human institutions, demonstrating that human beings are what they are because of a series of events that took place at the beginning of time; this history is narrated and transmitted intact through myths. By performing the initiation ceremony, the participant re-lives the sacred history of the world, including its creation and shares the fate of the supernatural being who was killed by the very humans that the supernatural being was trying to renew.

Eliade's theory of myth has come in for criticism from anthropologists. We will discuss these concerns from two perspectives: myth and ritual. On the myth side, John A. Saliba offers three critiques of Eliade's conception of myth. ${ }^{304}$ First, Saliba points out that Eliade does not explicitly address the question of the reception of myth by people, whether they accept it or not. Second, Saliba argues that Eliade confines myth solely to the past, even though some myth betokens a good life in the future. Finally, Eliade restricts myth's function to only the religious and social levels; however, it could play a role on political and moral levels as well. Saliba rightly points out some inadequacies of Eliade's comprehensive theoretical effort to accommodate all myths. However, Eliade's theory fares well when it comes to explaining the

\footnotetext{
${ }^{301}$ Rappaport, Ritual, 26-27.

302 Ibid., 27.

${ }^{303}$ Eliade, Rites and Symbols, x.

${ }^{304}$ John A. Saliba, “'Homo Religiosus' in Mircea Eliade: An Anthropological Evaluation (Leiden: E. J.
} Brill, 1976), 125-29. 
Christ myth, as we will see below, except for the emphasis on the primordial past. ${ }^{305}$ On the ritual side, there has been copious debate on the exact relationship between myth and ritual for the last hundred-plus years. ${ }^{306}$ For Eliade, ritual serves as a fundamental function in the fulfilment of myth because, when re-enacted, myth returns the participant to the primordial time and thus closer to god. The myth-ritualist theory has undergone revisions and tests and been largely rejected by theorists who have concluded that rituals and myths exist independently of each other. ${ }^{307}$ However, the theory still has much to offer for those cases in which myth and ritual do operate together. Segal signals a path for the future of myth-ritualism by treating myth as an indispensable part of the ritual, when the ritual is understood as a performance. ${ }^{308}$ Myth and ritual are two aspects of the same reality: "myth is a verbal aspect of ritual whilst ritual is a notional aspect of myth." 309

Using Eliade's theory of myth as modified by Saliba's critique, we now analyse the creation and Christ myths entailed in the baptism ritual in Rom 5:12-21 and Rom 6:1-11. The first observation to be made of the connection between these two pericopes is that the particle oṽv in Rom 6 signals a continuation of thought from Rom $5 .{ }^{310}$ In the immediate context, oṽv refers to Rom 5:20-21, in which Paul speaks of the universal principle that where sin increases, grace abounds, which elicits the follow-up objection in Rom 6:1b. ${ }^{311}$ Nevertheless, we suggest that the particle can also direct the attention to the totality of the thought unit in Rom 5:12-21 since the arguments in Rom 6 flow from the development of Paul's thought in Rom 5. If so, the baptism ritual imagery employed in Rom 6 corresponds to the creation myth in Rom 5. This is further bolstered by the credo statement embedded in the baptismal formula in Rom 6:3-8, which contains the Christ myth. Thus, this is the first time in Paul's writings in which baptism ritual operates with a myth.

${ }^{305}$ For a balanced assessment of Eliade's works see Guilford Dudley III, Religion on Trial: Mircea Eliade and His Critics (Philadelphia: Temple University Press, 1977), especially 119-62.

${ }^{306}$ For a historical survey of myth-ritualist theory, see Robert A. Segal, "Myth and Ritual," in Theorizing Rituals: Issues, Topics, Approaches, Concepts, ed. Jens Kreinath et al., Numen 114 (Leiden: Brill, 2006), 10121.

${ }^{307}$ E.g., W. Ridgeway, “The Dramas and Dramatic Dances of Non-European Races,” ed. Robert E. Segal (London: Wiley, 1988), 359-78; N. H. Snaith, The Jewish New Year Festival: Its Origins and Development (Eugene, OR: Wipf \& Stock, 1947); W. W. Douglas, "The Meanings of 'Myth' in Modern Criticism," Modern Philology 50 (1953): 232-42; and Joseph Fontenrose, The Ritual Theory of Myth (Berkeley: University of California Press, 1966).

${ }^{308}$ Segal, "Myth and Ritual," 121.

${ }^{309}$ Gregory Nagy, "Can Myth Be Saved," in Myth: A New Symposium, ed. Gregory Schrempp and William Hansen (Bloomington: University of Indiana Press, 2000), 240-48.

310 Agersnap, Baptism, 233. The following commentators also assume continuity of thought from Rom 5 to Rom 6: F. F. Bruce, The Epistle to the Romans (London: Tyndale Press, 1963), 68, 134; Matthew Black, Romans (NCBC, Grand Rapids: Eerdmans. 1973), 92; and Leon Morris, The Epistle to the Romans (Grand Rapids: Eerdmans, 1988), 243.

${ }^{311}$ Agersnap, Baptism, 233-34. 
The myth that accompanies the baptism ritual departs from Eliade's description of the kind of myths found in primitive societies. Whereas Eliade's myths reflect a primordial golden age, the myth in these pericopes speaks of the primordial fall and subsequent redemption of humanity. In fact, Paul forges the creation myth in Genesis with the Christ myth developed to form a sweeping redemptive story that stretches back to the beginning and continues to the present day. These two registers of the myth appear in Rom 5:12-21, in which the story of Adam's fall and Christ's redemption has happened and in the creedal statement embedded in Rom 6:3-8, which originates from the Christ myth in 1 Cor 15:3-5, 20-28. There, the resurrected Christ will, in his second advent, fulfil the messianic expectation of subjugating all nations under his reign.

The Christ myth functions as a paradigm or model in which the current situation of humanity is articulated. The paradigmatic nature of the Christ myth is evident in Paul's use of

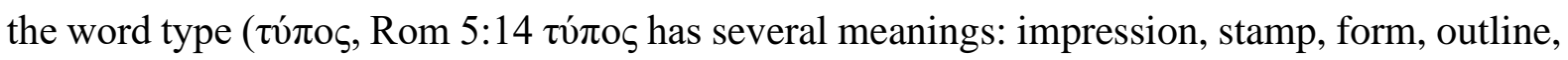
pattern, or model, ${ }^{312}$ and Paul uses it elsewhere to refer to Israelite history as a type for Christ's people and his moral example (1 Cor 10:6; 1 Thess 1:7; 2 Thess 3:9; Phil 3:17). Both Adam and Christ play a fundamental typological role, as their actions affect the rest of humanity. ${ }^{313}$ Further evidence supporting this observation lies in the parallel that Paul draws between Adam $^{314}$ and Christ, ${ }^{315}$ who are each the prototype of a dominion: the dominion under Adam and the dominion under Christ, as indicated by the constellation of head phrases (Rom 5:12, $16,17,18,19)$. The corresponding phrases refer to the participants whose situations are largely determined by the actions resulting from these two prototypes (Rom 5:12, 15, 16, 17, 18, 19).

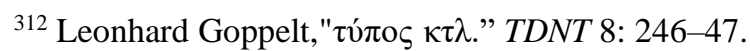

313 See Brendan Byrne, "'The Type of the One to Come' (Rom 5:14): Fate and Responsibility in Romans 5:12-21," ABR 36 (1988): 25-30; A. J. Hultgren, Paul's Letter to the Romans: A Commentary (Grand Rapids: Eerdmans, 2011), 226; cf. 227.

314 Jewish literature contemporary with Paul attempts to explain the relationship between the sin of protohuman beings and their progeny; see Sir 25.24; cf. Apoc. Mos. 32.2; Wis 2.24; 2 Bar. 17.3.

315 Some scholars locate the notion of the original man as a redeemer figure in Gnostic sources, but this view has largely fallen out of favour. See, for example, Rudolf Bultmann, "Adam and Christ According to Romans 5," in Current Issues in New Testament Interpretation: Essays in Honor of Otto A. Piper, ed. W. Klassen and G. F. Snyder (New York: Harper, 1962), 154; Günther Bornkamm, Das Ende des Gesetzes: Paulusstudien, BeVT 16 (Munich: Christian Kaiser, 1952), 83; Egon Brandenburger, Adam und Christus: ExegetischReligionsgeschichtliche Untersuchung zu Röm. 5:12-21 (1. Kor. 15), WMANT 7 (Neukirchen: Neukirchener Verlag, 1962), 168-80. See also Agersnap's critique of Brandenburger's argument in Baptism, 228-31. 
Terms signifying prototype

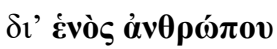

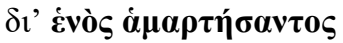

Évò $\varsigma \pi \alpha \rho \alpha \tau \omega ́ \mu \alpha \tau \imath$

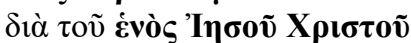

$\delta \mathrm{l}^{\prime}$ ह่vò $\varsigma \pi \alpha \rho \pi \tau \omega ́ \mu \alpha \tau o \varsigma$

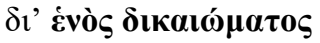

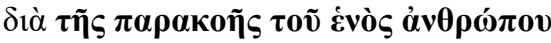

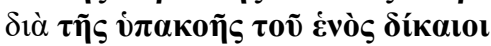

Terms signifying participants

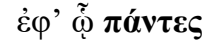

oi $\pi \mathbf{0} \lambda \lambda \mathbf{o ̀ ̀}$

$\dot{\varepsilon} \kappa \pi 0 \lambda \lambda \tilde{\omega} v$

$\pi 0 \lambda \lambda \tilde{\omega} \mu \tilde{\alpha} \lambda \lambda \mathrm{ov}$

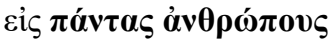

Adam, as the first prototype of the image of God, failed miserably through his act of transgression, whereas Christ as the second prototype (the image of God) brings forth a new beginning for humanity through his act of obedience. Regarding the relationship between the prototypes with the antitype (i.e., the participants), the Christ myth enacted in the baptism ritual enables participants to re-live the sacred past. They experience the restoration of the image of God: the reality of the Christ myth matches the reality to which the baptism ritual refers. ${ }^{316}$

Another element in Rappaport's definition of ritual performance is the entailment of "the generation of the concept of the sacred." The presence of sacredness or ultimate sacred postulates is created in the performance of ritual. Not only does ritual achieve the conventional effects when it is performed but also establishes the very conventions through which those effects are realised, from the procedures to achieve such effects to the understanding of them that defines the character of cosmos. Thus, the concept of ultimate sacred postulates finds its grounding in the ritual performance for its validity as a social act. Rappaport qualifies the definition of sacredness by distinguishing between the concept of sanctity as a religious discourse and the object signified, the sacred itself.

The baptism ritual manifests the presence of sanctity and generates the ultimate sacred postulates through the sacred discourse embedded in the baptism formula pronounced at the ceremony. The justification formula in 1 Cor 6:11 contains a triadic form that expresses the concept of sacred. The first term, $\dot{\alpha} \pi \mathrm{\alpha} \lambda \mathrm{ov} \omega$, invokes the imagery of a cleansing bath washing away pollution and sin (Acts 2:16; Eph 5:26; cf. Heb 9:2). This is the first instance where Paul links the baptism ritual with the notion of purification. Moshe Blidstein notes that, since Paul does not employ the most common term for purification, the reference to baptism as a rite of purification is not explicit. ${ }^{317} \mathrm{We}$ argue that Paul is clearly referring to baptism as a rite of

316 Gregory Nagy, "Can Myth Be Saved," 243.

${ }^{317}$ Moshe Blidstein, "Baptism as Purification in Early Christian Texts," in Purity, Community, and Ritual in Early Christian Literature (Oxford: Oxford University Press, 2017): 109. 
purification as denoted by the term $\dot{\alpha} \pi \varepsilon \lambda \sigma v ́ \sigma \alpha \sigma \theta \varepsilon .{ }^{318}$ The notion of baptism associated with

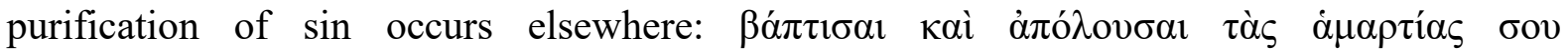

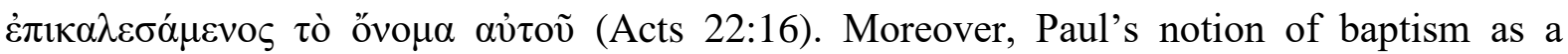
purification of sin has been prepared by John the Baptist, whose baptism of repentance is

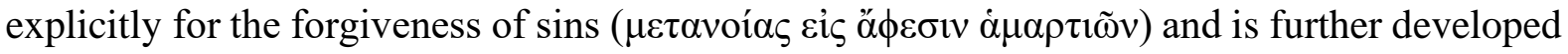
by later New Testament writers (Eph 5:25-27; Tit 3:5-6; Heb 10:21-22; cf. Heb 9:19-22; 12:24; 1 Pet 3:21). Outside of the New Testament, the concept of a cleansing bath appears in both Greco-Roman religions and Judaism. The mystery cults of Isis recorded in Apuleius's Metamorphoses require a rite of purification before allowing participation in the mystery proper (Sueto lavacro, abluit, 11.23), reflecting the Hellenistic view that demonic action or a material miasma are involved in defiling a person in any major event that marks a person's life. ${ }^{319}$ Likewise, the Qumran sect had terms for purification in their liturgical texts: הזיה, רחץ, טהר. Against this religious background, what sets early Christ followers apart from purification rites in other religions is that the baptism ritual assumes the functions of both purification and initiation rites. ${ }^{320}$ Thus, the discourse of washing alludes to the idea that God is pure - without any dirt or pollution - and those who approach him must be in a state of purity, lest their impurity contaminate the sacred realm.

The second term, $\dot{\alpha} \gamma \mid \alpha \dot{\zeta} \omega$, signifies the notion of the cultic or moral condition of God, people, or things in the Old Testament, a sense that Paul inherited. In the context of 1 Cor 6:111, the concept of holiness has both anthropological and eschatological dimensions. As to the former, Paul urges his readers to abandon the practices of immorality listed in vv. 9-10 because they have been baptised and made new people. Holiness pertains to the moral uprightness of the individuals who have participated in the baptism ritual, which is supposed to transform them into newly created beings. Paul here places great emphasis on sexual immorality amongst the Corinthian community. ${ }^{321}$ The grievance mentioned in v. 1 could refer to sexual immorality since, in the previous chapter, Paul discusses God's judgement upon those who practice immorality and the categories of vices (1 Cor 5:1-2,9-12); these are repeated in 1 Cor 6 on

318 See Ferguson, Baptism in the Early Church, 150; Hartman, "Into the Name," 63-66; Michael Newton, The Concept of Purity at Qumran and in the Letters of Paul (Cambridge: Cambridge University Press, 1985); and Anders Klostergaard Petersen, "Rituals of Purification, Rituals of Initiation: Phenomenological, Taxonomical and Culturally Evolutionary Reflections," in Ablution, Initiation, and Baptism: Late Antiquity, Early Judaism, and Early Christianity, ed. David Hellholm et al. (Berlin: De Gruyter, 2011), 3-40.

${ }^{319}$ Robert Parker, Miasma: Purification and Pollution in Early Greek Religion (Oxford: Clarendon Press, 1983).

${ }^{320}$ Petersen, "Rituals of Purification," 34-35.

${ }^{321}$ Paul's view of sexual morality reflects the common teaching of Judaism on fornication and sexual perversion; see Josephus, Ag. Ap. 2.199, 273-275; Philo, Abr. 135-137; Spec. 3 39; Somn. 2.9; los. 20. 
the topic of judgement, with the same categorisation of vices $(6: 1-5,9-10) .{ }^{322}$ Elsewhere in

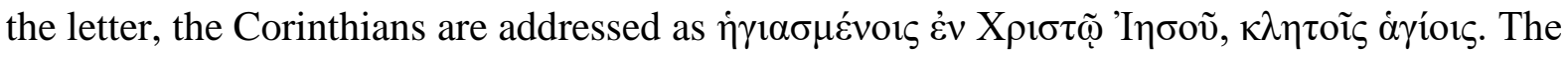
"in Christ" phrase in this passage relates to the idea of sanctification. At 7:14, Paul speaks of sanctification in participatory terms: the unbelieving spouse is sanctified through union with a believer. ${ }^{323}$ In 1 Cor 6:2-3, Paul relates the notion of saints who participate in the eschatological judgement of angels and the world. Earlier Jewish literature had espoused the notion that holy ones would participate in the eschatological judgement of fallen angels $(1$ En $1.9 ; 19.1)$ and the nations (38.5), with judgement beginning in the household of God (T. Levi 17.11). The concept of sanctification expressed in this discourse speaks of God as the source of holiness, so those who are called "in Christ" are to participate in his holiness in both the individual moral sphere and in the eschatological judgement of the world.

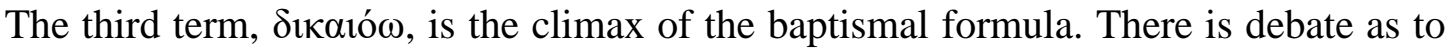
the sense of the term in the passage: does it have the full sense of the Pauline concept of justification? There are three levels of sense attached to $\delta$ iкaı́ $\omega$. The first is the pre-Pauline sense contained in the formula; ${ }^{324}$ the second level is the immediate context in which it occurs, which opposes it to ä $\delta$ เ writings that have employed the term justification. ${ }^{326}$ We suggest that the second level of sense should be favoured in this context given the arrangement of rhetorical units in 1 Cor 6:9-11, in which Paul compares the states of an unrighteous and a righteous person (vv. 10-11). ${ }^{327}$ Moreover, although synthesizing Paul's notion of justification from all his writings help gets a fuller picture, it could blur the specific components of justification contained in a given passage since Paul develops the idea over a period of time and only provides its full articulation in the Letter to the Romans. Given that the topic of judgement pervades the pericope (the litigation amongst the believers, the saints' judgement of the world, the contrast between the unjust and

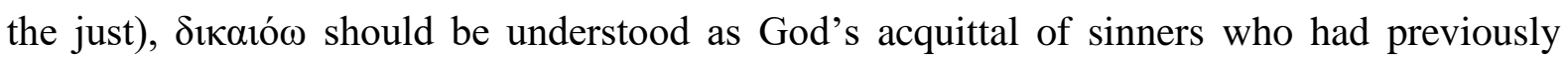
brought just judgement upon themselves. ${ }^{328}$ In baptism, God manifests his judgement in

${ }^{322}$ Stephen J. Chester observes that "the vice-list of 6.9-10 is not, strictly speaking, a catalogue of sins, but of types of sinner. Paul speaks not of those who commit sexual immorality, but of the sexually immoral and so on"; Conversion at Corinth: Perspectives on Conversion in Paul's Theology and the Corinthian Church (London: T\&T Clark, 2003), 134.

${ }^{323}$ Chester, Conversion, 141.

${ }^{324}$ Lohse, "Taufe und Rechtfertigung."

${ }^{325}$ Schnackenburg, Baptism in the Thought, 4.

${ }^{326}$ Beasley-Murray, Baptism, 165.

${ }^{327}$ Jean-Noel Aletti, Justification by Faith in the Letters of Saint Paul Keys to Interpretation, trans. Peggy Manning Meyer (Rome: Gregorian \& Biblical Press, 2015), 31.

${ }^{328}$ James B. Prothro, Both Judge and Justifier: Biblical Legal Language and the Act of Justifying in Paul (Tübingen: Mohr Siebeck, 2018), 125. 
justifying sinners' rightful place before him. Thus, the language of justification expresses the notion of a God who sits in his heavenly tribunal executing cosmic judgement on all of creation, beginning with his own people (1 Pet 4:17).

All these terms contribute to the overall discourse of sanctity made manifest in baptism. The term $\dot{\alpha} \pi \circ \lambda \circ v^{\prime} \omega$ denotes the negative aspect of purity in both physical and moral senses. The term $\dot{\alpha} \gamma i \alpha ́ \zeta \omega$ signifies that God is the source of holiness, a quality imitated by his people participating in the eschatological judgement. Finally, the term $\delta$ iкaı́ $\omega$ refers to God as the initiator of the judgement whose effect is the transformation of the person into a newly created being. By a solemn pronouncement of the baptismal formula containing the sacred discourse, the baptism ritual establishes the sanctity of the ultimate sacred postulates, the originator and bestower of sanctification.

\subsubsection{Transformation: Virtuality and historical emergence}

We now reach the crucial moment of the baptism ritual: the process of transformation. Victor Turner's concepts of liminality and communitas have been fruitfully employed by scholars to understand the baptismal process of transformation. ${ }^{329}$ However, there are aspects of the ritual process that are missing in the theory. Instead of understanding ritual as having an immediate relation to the external reality it seeks to affect, Bruce Kapferer proposes that ritual as a technological dynamic creates a virtual space in reality that constitutes a suspension of some of the flow of ongoing existence to manipulate and reconfigure human reality. Turner's approach bears a resemblance to the virtual ritual in that the liminal is a period of re-orienting chaotic moments outside of a structure into a new scheme and vision of reality. The difference lies in the relation to the external world: Turner's theory is directed to the representation and value of the outside world, whereas Kapferer's approach has no immediate relation to external reality. It involves the interior re-orientation and re-positioning of the person involved. These two theories can complement each other in explaining the totality of transformational processes, both internal and external. To Turner's liminal theory we add the concept of emergence: what ritual performance brings about in social reality. Writing on the processes of ritual performance, Schieffelin argues that the efficacy of a ritual performance revolves around the issue of emergence, which is what happens by virtue of performance: an irreversible quality of experience or a situation that the participant has experienced. ${ }^{330}$ The experience of communitas

${ }^{329}$ See Strecker, Die Liminale Theologie, and Asano, Community-Identity, 180-206.
${ }^{330}$ Schieffelin, "On Failure and Performance," 64. 
becomes historical emergence if the ritual succeeds, and that hinges on factors such as performative authority and contingency. Finally, the movement of historical-social reality that emerges in the ritual into the domain of social event constitutes the movement of ritual symbolism or efficacy into the human world.

We focus our analysis on the baptismal formula found in Gal 3:27-28 because it directly speaks of transformation, which Christ believers experience at the baptism. Using the transformation theories outlined above, we designate v. 27 as the interior aspect of transformation and v. 28 as the emerging social reality resulting from the ritual performance.

The Baptism ritual creates a virtual space in which the participants undergo

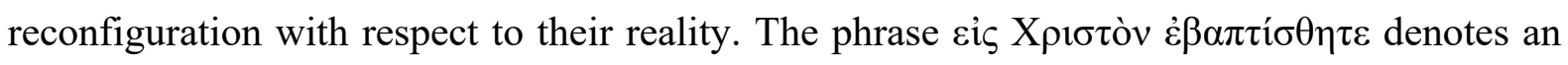
entry point for the participants to enter a "phantasmagoric space," and this space is Christ's sphere. The preposition eic should be taken in a local sense, as a movement into Christ's sphere from outside it. ${ }^{331}$ Schnackenburg argues that the counter-example in 1 Cor 10:3, eỉ tòv M

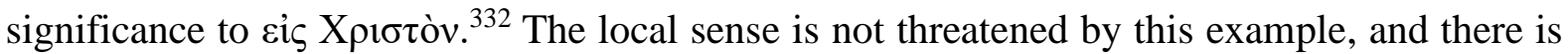
no need to resort to a mystical significance to preserve it. If we employ Kapferer's theory of ritual as a dynamic technology that creates a virtual space, the baptism of Moses in the Red Sea could be interpreted as an imaginary space where the redemption of the Israelites occurs. Israelites commemorate this redemptive act annually at the Passover meal at which the saga is ritually recounted. One should also note that Paul is interpreting the Old Testament account typologically from baptism, focusing on the ritual significance of baptism indicated by the language of spiritual drink (1 Cor 10:3-4; cf. 12:13). ${ }^{333}$ Furthermore, the local sense of $\varepsilon i \varsigma$

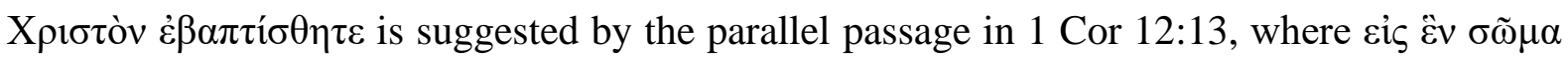
$\dot{\varepsilon} \beta \alpha \pi \tau i ́ \sigma \theta \eta \mu \varepsilon v$ evinces a local sense. Interpreters have generally taken $\varepsilon \dot{\zeta} \varsigma \tilde{\varepsilon} \nu \sigma \tilde{\omega} \mu \alpha$ to be the place in which the baptizands are incorporated, which signifies that Christ's body pre-exists the members. ${ }^{334}$ Thus, baptism translates the participants into a Christ space in which the transformation happens.

This self-contained Christ space enables the participants to break free from the determinants that inhibit them to realise their true potential and become children of God. The

\footnotetext{
${ }^{331}$ Douglas J. Moo, Galatians (Grand Rapids: Baker Academic, 2013), 252; Das, Galatians, 381-82; J. Louis Martyn, Galatians: A New Translation, with Introduction and Commentary (New York: Doubleday), 374.

332 Schnackenburg, Baptism in the Thought, 23.

${ }^{333}$ Hans Conzelmann, 1 Corinthians: A Commentary on the First Epistle to the Corinthians, ed. George W. MacRae, trans. James W. Leitch (Philadelphia: Fortress Press, 1975), 165-66.

${ }^{334}$ Conzelmann, 1 Corinthians, 212.
} 
process begins with their descent into the virtual space of baptism. This is illustrated by Eph 2:4-6 wherein the writer discloses the notion that Christ believers ascend a throne in heaven with Christ at baptism. The reference to baptism in Eph 2:4-6 is made clear by setting it against the passages in Eph 1:20 and Col 2:13. . $^{335}$

Col 2:13

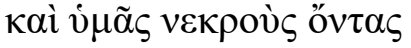

$\tau$ ○ĩऽ $\pi \alpha \rho \alpha \pi \tau \omega ́ \mu \alpha \sigma ı v$

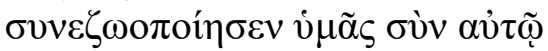

Eph 1:20

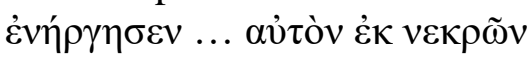

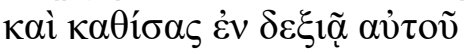

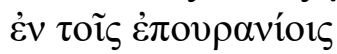

Eph 2:6

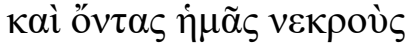

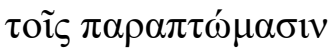

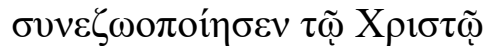

Eph 2:6

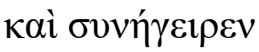

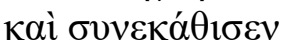

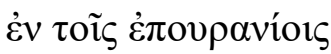

$\dot{\varepsilon} v$ X

These two passages demonstrate that the language of death and rising is a common motif used to describe the effects of baptism in the early Christ movement. What is novel about the writer of Ephesians is that he adds another element to this common stock of baptism symbolism; namely, the triumphal procession into heaven with Christ, offering Ps 68:19 (Eph 4:8-10) as biblical support. In baptism, the participants are translated from the terrestrial sphere into the celestial sphere where they will reign with Christ. Once the participants have descended into the Christ space, they begin to engage in their existential formation by identifying with the

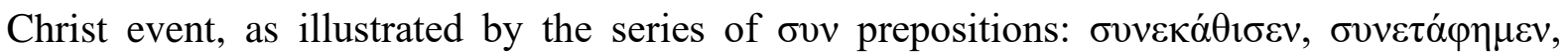

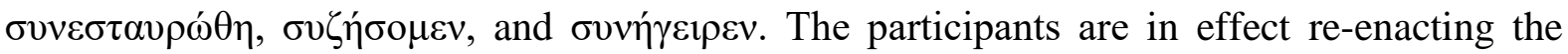
Christ myth, which happens outside of historical time. By engaging in the Christ myth, the participants seek to be liberated from their current predicaments: bondage to sin, death, and law (Rom 6:11-22). ${ }^{336}$ These are the determinants that inhibit them from achieving true

335 Schnackenburg, Baptism, 74-75.

336 There is a debate on the different eschatological view espoused in undisputed Pauline letter Romans 6:1-11 and Ephesians 2:6, indicated by the different tenses used in these two letters: Paul employs future tense in speaking of future resurrection in Romans 6:5, 8 ( $\tau \tilde{\eta} \varsigma \alpha \dot{\alpha} \alpha \sigma \tau \alpha \dot{\alpha} \sigma \varepsilon \omega \varsigma \dot{\varepsilon} \sigma o ́ \mu \varepsilon \theta \alpha$; $\sigma 0 \zeta \bar{\eta} \sigma o \mu \varepsilon v)$, and the author of

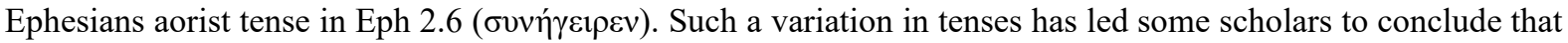
Ephesians contradicts with Romans regarding the resurrection. However, upon closer examination the seemingly contradiction is resolved by looking at the context in which resurrection motif is used. In Romans 6 both references to future resurrection is in apodosis of the conditional clause, preceded by protasis ("For if we have been united with him in a death like his" and "we believe that we will also live with him"). To state differently, resurrection has its logical and temporal pre-condition, that is, one needs first to be united with Christ's death. Thus, resurrection in Romans 6 has both present and future aspects. In Ephesians 2:6 the resurrection language is that of Col 3:1-2 where resurrection life equates that of heavenly life. Both Ephesians and Colossians speaks of spiritual resurrection or status that one gains when they are in Christ in that one has been transferred from the domain of death and corruption to the domain of life and immortality (Col 1:13). On the other hands, Ephesians also evinces the notion of future resurrection in 2:7 ("the ages to come"). Therefore, the seemingly contradicting aspect of present and future resurrection is only a matter of different perspective, whether when one speaks of 
potential, that they are created in the image and likeness of God. From the context, Gal 3 speaks of the topic of the children of God; Paul recounts that before the advent of faith, the Galatians were under the custodianship of the law and hindered by its operation (Rom 7:5-6; cf. 2 Cor 3:6). After faith has come, the law ceased to function as a restrain to sin but led them to Christ, who is the fulfilment of the law. The Galatians are now fully adopted as children of God, as signified by the term $\dot{\varepsilon} v \varepsilon \delta v ́ \sigma \alpha \sigma \theta \varepsilon,{ }^{337}$ which denotes that they have moved from spiritual infancy to maturity in Christ ( Gal 3:3). ${ }^{338}$ In short, the baptism ritual affords the participants a virtual space amidst the flow of reality to achieve a spiritual perfection as children of God. ${ }^{339}$

During the process of re-orientation and re-configuration in the virtual space created by the baptism ritual, the participants experience the "limbo of statuslessness" 340 or betwixt and between the positions and social status they have been "assigned and arrayed by law, custom, convention and ceremonial." 341 The initiands in the state of liminality are "likened to death, to being in the womb," waiting to be fashioned anew. The communitas that is born amongst the participants "has an existential quality, involve[ing] the whole man in his relation to other whole men." At the climax of the baptism ritual, the neophytes are declared a new creation, for "there is neither Jew nor Greek, there is neither slave nor free, there is neither male nor female;

future resurrection temporally from the perspective of redemptive history or one speaks of present (spiritual) resurrection logically from the posture of spiritual transformation. Andrew Lincoln T., Word Biblical Commentary. Andrew T. Lincoln,(Waco, Tex: Word Books, 1990), 106-7; Harold W. Hoehner, Ephesians : an Exegetical Commentary / Harold W. Hoehner (Grand Rapids, Mich: Baker Academic, 2002); Peter Thomas O'Brien, The Letter to the Ephesians / Peter T. O'Brien (Grand Rapids, Mich: Eerdmans, 1999), 146-48; Stephen E. Fowl, Ephesians (2012): A Commentary (Louisville: Westminster John Knox Press, 2012), 76-8.

${ }^{337} \mathrm{Kim}$ (Clothing Imagery, 229) concludes that the metaphor, "which is thus dominated by the AdamChrist motif, seems to presuppose that Adam had originally been clothed with divine elements in the image of God, but that he was stripped of these elements at the Fall; that although all human beings have been born to this fallen state, those who are united with Christ in baptism are restored to the original Adamic state."

${ }^{338}$ Paul here may well echo the practice of donning the toga virilis for Roman boys, marking their manhood with clothing imagery. See J. Albert Harrill, "Coming of Age and Putting on Christ: The Toga Virilis Ceremony, its Paraenesis, and Paul's Interpretation of Baptism in Galatians," NovT 44, no. 3 (2002): 252-77. Neither Keener (Galatians, 304) nor John Bligh, Galatians: A Discussion of St. Paul's Epistle (London: St. Paul Publications, 1970), 325, see Paul as connecting "putting on" with maturation. Although Paul does not explicitly connect "putting on" with the idea of maturation, the immediate context is clear. First, Paul mentions that the Galatians were under the custodianship of the Law, invoking the imagery of pedagogues who led young boys in morality and education in the ancient world. Second, Paul in Gal 3:3 mentions that the Galatians are preoccupied with spiritual perfection, thinking that the baptism ritual needs to be supplemented with the circumcision rite. Finally, Paul in Gal 3:27-29 explains that when faith comes, the Law leads them to Christ, who is the perfection of the Law, the maturation of faith. See Norman H. Young, "Paidagogos: The Social Setting of a Pauline Metaphor," NovT 39, no. 2 (1987): 150-76.

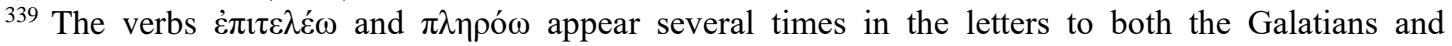
Colossians in the context of religious perfection. In the former, Paul uses $\dot{\varepsilon} \pi \imath \varepsilon \lambda \dot{\varepsilon} \omega$ in connection with a desire to reach perfection through carnal means, that is, circumcision (Gal 3:3, $\dot{\varepsilon} \pi \tau \varepsilon \lambda \varepsilon \tilde{\tau} \sigma \theta \varepsilon, 5: 16, \tau \varepsilon \lambda \varepsilon \dot{\varepsilon} \sigma \eta \varepsilon)$. For a thorough study of the religious background of $\dot{\varepsilon} \pi \tau \varepsilon \lambda \varepsilon \dot{\varepsilon} \omega$ in both the New Testament and the Greco-Roman context, see R. S. Ascough, "The Completion of a Religious Duty: The Background of 2 Cor 8:1-15," NTS 42 (1996): 584-99.

${ }^{340}$ Turner, The Ritual Process, 97.

${ }^{341}$ Ibid., 94. 
for you are all one in Christ Jesus" (Gal 3:28). This is a program of engineering a new humanity that transcends the ethnic, social, and sexual distinctions into which people are categorised.

On the ethnic level, the baptism ritual engineers a new humanity based on a common spiritual ancestry in Christ. The conflicts between the Jews ${ }^{342}$ and Greeks ${ }^{343}$ has a long history, which can be traced back to the late first century of the common era, when Jews settled in the cities of Asia Minor, which were full of Greek or Hellenised citizens. ${ }^{344}$ The conflicts arose amongst these two ethnic groups when they trespassed the boundary markers of the other, markers defined by a common history, common culture, and shared physical elements. ${ }^{345}$ Having this historical background in mind, Paul envisions a program of universalising the differences amongst the Jews and the Greeks or Gentiles by proposing that, in the overarching divine plan, both Jews and the Gentiles have a common ancestor in Abraham. The Jews are the offspring of Abraham by virtue of their blood relation, while the Gentiles become the children of Abraham through Christ, who is the heir according to the promise. Paul uses the argument that what is true of the whole is also true of each part. ${ }^{346}$ Since Christ is the whole of which the promise of old was foretold, the Gentiles, as part, are included in the Christ through baptism. In baptism the former boundary markers that distinguish different ethnic groups give way to a new social identity in Christ defined by a common profession of faith (Eph 2:11-22; 4:5) and a new life in Christ marked not by the physical incision of circumcision but by a spiritual transformation of the inner person (Col 2:11-12; 3:11).

On the social level, the social stratification is rendered irrelevant amongst the Christ believers. Social criticism of institution of slavery has a long tradition in both the classical authors and Jewish writers. ${ }^{347}$ One of the earliest classical voices raised against slavery was Alcidamas who reputed to have said: 'God left all men free; nature has made man a slave.,'348

${ }^{342}$ Betz (Galatians, 190-91) observes that naming the Jew first in the pair "Jew and Greek" indicates that Jews themselves give up their religious prerogatives, whereas naming the Greek first in Col 3:11 implies that the Greeks relinquish their socio-cultural supremacy.

343 The term Greeks has an all-embracing meaning, "reflecting the all-pervasive culture in the Mediterranean world, but also the Jewish sense of distinctiveness within an intellectual culture of which they were a part"; Betz, Galatians, 205.

${ }^{344}$ Christopher D. Stanley, “'Neither Jew nor Greek': Ethnic Conflict in Graeco-Roman Society,” JSNT 64 (1997): 101-02.

345 Stanley, "Neither Jew nor Greek," 111.

${ }^{346}$ G. Walter Hansen, Abraham in Galatians: Expository and Rhetorical Contexts (Sheffield: JSOT Press, 1989), 136.

347 On the Jewish attitude towards slavery, see Solomon Zeitlin, "Slavery During the Second Commonwealth and the Tannaitic Period," JQR 53, no. 3 (1963): 185-218; Haim H. Cohn, "Slavery," EncJud 14 (London: Macmillan, 1971), 1655-60.

${ }^{348}$ Quoted in Aristotle, Rhet. I, 13.2; see also Aristotle, Pol. 1.2.3, 1253b 20-24. 
Since then, this criticism was incorporated into Cynic and Stoic philosophy. ${ }^{349}$ The Jewish philosopher, Philo accepted this old teaching against slavery in his writings, citing some Jewish sects do not own slaves. ${ }^{350}$ Against this long tradition of social criticism of slavery, Paul is not advocating an abolishment of the social institution of slavery otherwise he would not send the slave Onesimus back to his master and advise Christian slaves to be submissive to their masters. ${ }^{351}$ The social status of individuals along with any privileges and prestige attached to it has no bearing in the Christ believing community. In this new society, every member is equal before Christ who is the master of all and in whom lies the true freedom (1 Cor 7:22; Gal. 51314). This freedom is a freedom from the bondage to the law and the operation of the elementary

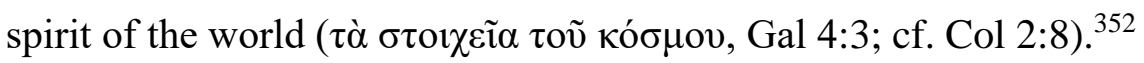

Finally, on the biological level, it involves the elimination of gender and sex differences. Various interpretations have been suggested for the last triplet of "neither male nor female." The first interpretation sees an echo of Gen 1:27, where humanity is created in the image of God; Philo interprets this as an immaterial ideal that is not distinguished by sexual characteristics. ${ }^{353}$ Another interpretation, which Fiorenza proposes, posits that Paul declares the annulment of human relations and propagation. ${ }^{354}$ Other views understand the phrase to be a metaphysical removal of biological differences in terms of an androgyny myth ${ }^{355}$ or spiritual reality in which value judgments about sex are neutralised ${ }^{356}$ in an eschatological reality that will only be fully realised in the future. ${ }^{357}$ We suggest that the phrase "neither male nor female" should be understood as a statement on the ontological unity in the body Christ, in which bodily characteristics like biological sex have been rendered neutral through baptism. The baptismal 1965), 101

${ }^{349}$ See H. C. Baldry, The Unity of Mankind in Greek Thought (Cambridge: Cambridge University Press,

${ }^{350}$ Philo, Spec. 2.69: "For nobody is by nature a slave"; see also 2.122; Contempl. 9, 70; Prob. 79; Josephus, A.J. 18.21.

351 See Betz, Galatians, 193.

352 Scholars have generally associated the meaning of $\sigma \tau 0 \imath \chi \varepsilon i \tilde{\alpha}$ with calendarial worship of gods in heaven, as Paul refers to the calendarial observations. Bruce connects the list of days, months, seasons, and years to the name of pagan deities who share the names of planets; see The Epistle of Paul to the Galatians, 29-30. De Boer (Galatians, 254) proposes that "the Galatians venerated the four elements of the universe as gods; this veneration involved calendrical observances." If one takes the parallel passage in Col 2:8 into account, then the elemental sprit of the world could refer to the fundamental fabrics that hold a human society together. These fabrics or elements are the philosophy, religion, laws, and regulations that govern the various social and religious aspects of a given society.

353 According to Philo, we have three images of God in Philo. The Logos, the intellect and the ideal human being. See Philo, Opif. 134, 165; Leg. 2.25, 2.38, 2.49, 2.73.

${ }^{354}$ Elisabeth Schüssler Fiorenza, In Memory of Her: A Feminist Theological Reconstruction of Christian Origins (London: SCM Press, 1983), 211.

${ }^{355}$ Meeks, "The Image of the Androgyne", 165-208.

${ }^{356}$ Robin Scroggs, "Paul and the Eschatological Woman," JAAR 42, no. 3: 532-537.

${ }^{357}$ Ben Witherington, "Rite and Rights for Women-Galatians 3.28," NTS 27, no. 5, (1981): 593-604. 
formula in 1 Cor $12: 13$ and Col 3:10-11 is immediately followed by the theme of unity in Christ: 358

\begin{tabular}{|c|c|}
\hline & 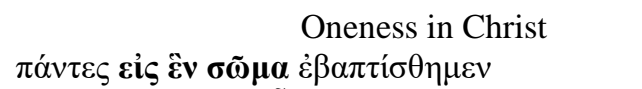 \\
\hline ial 3.2 & 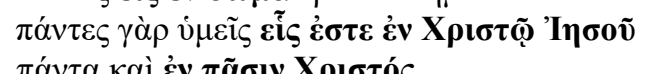 \\
\hline
\end{tabular}

The theme of unity is inextricably linked to the concept of the body of Christ in Paul's corpus. There are two reasons for this interpretation. First, when Paul speaks of the body of Christ, it is more than just a metaphor for the relationship between Christ and the believers; it is a living organism consisting of different members with different functions, with Christ as the head. Second, there is the concept of union with Christ present in Gal 3:27-28. Campbell points out that the language of "putting on Christ" implies not a choice about conduct but "a permanent spiritual reality" that makes clear the union between Christ and the believer. ${ }^{359}$ Wikenhauser elucidates what union with Christ might mean for the believer: "The new relationship with Christ is not merely ethical, it is ontological. ... The man who 'puts on Christ' gains a share in Christ's being, and this participation produces 'Christ in us,' the 'new man."”360

The transcending of social categories in the baptism ritual brings about a new social reality, the eschatological emergence, which is contingent on the authority in the Christ community and the circumstances that accompany it. The ritual controversy in Galatians community revolves around the assertion of apostolic authority over the community, which has ramifications for the efficacy of the gospel. In the first two chapters of Galatians, Paul vehemently defends his gospel against the "agitators" 361 by appealing to divine revelation and commission and the consensus reached with the Jerusalem party $(1: 11-12,15-16 ; 2: 1-10)$. For Paul, his gospel and the commission to the Gentiles have a divine endorsement that is entirely

${ }^{358}$ David G. Horrell makes a similar observation about the oneness of believers in Christ in The Social Ethos of the Corinthian Correspondence: Interest and Ideology from 1 Corinthians to 1 Clement, Studies of the New Testament and Its World (Edinburgh: T\&T Clark, 1996), 83-84.

${ }^{359}$ Campbell, Union with Christ, 316, 321.

${ }^{360}$ Wikenhauser, Pauline Mysticism, 65-80.

${ }^{361}$ Various proposals have been made to determine the nature of the polemics and the identity of the opponents. Some interpreters understand these influencers as proclaiming another gospel that includes the observance of Jewish law, whereas Paul is proclaiming the gospel independent of them. Others suggest that these emissaries misrepresent the position of the Jerusalem apostles or act independently of them; see George Howard, Paul: Crisis in Galatia: A Study in Early Christian Theology, 2d ed., SNTSMS 35 (Cambridge: Cambridge University Press, 1990). Walther Schmithals proposes that they are Jewish or Jewish Christians Gnostics who claim that circumcision is part of the process of gaining access to knowledge; see "The Heretics in Galatia," in Paul and the Gnostics (Nashville: Abingdon Press, 1972), 16-64. The latest proposal, put forth by Mark D. Nanos, argues that the opponents are the Jewish community at large, which does not accept the Galatians' claim that they enjoy the same spiritual privileges as Jews because they accept Jesus as their messiah. See Mark D. Nanos, "The Inter- and Intra-Jewish Political Context of Paul's Letter to the Galatians," in The Galatians Debate: Contemporary Issues in Rhetorical and Historical Interpretation, ed. Mark D. Nanos (Peabody, MA: Hendrickson, 2002), 396-407. 
independent of human approval. If the Galatians accept the proposal made by the agitators to undergo circumcision, then Paul's gospel is incomplete and the baptism ritual, which is the performance of the gospel, has failed to bring about the eschatological emergence promised in the gospel. Against this possibility, Paul argues that baptism has achieved the agenda of the gospel, for Christ is the promised seed of Abraham, through whom the law has been fulfilled. Therefore, the rite of circumcision stipulated in the law has lost its validity. The historical circumstances around the baptism ritual are deeply rooted in the wider Judaic and GrecoRoman context in its ritual symbolism. Earlier in this chapter, we have discussed the cultural aspect of the baptism ritual in the wider cultural milieu; it exhibits the common motifs of transformation, purification, perfection, and eschatology. Indeed, the baptism ritual has incorporated the various motifs into its ritual symbolism and genre. The success of the baptism performance depends on using these symbols to bring about the quality of experience for the participants that is promised in the gospel. For the early Christ believers, it has succeeded in doing that because their experience has had an impact on society.

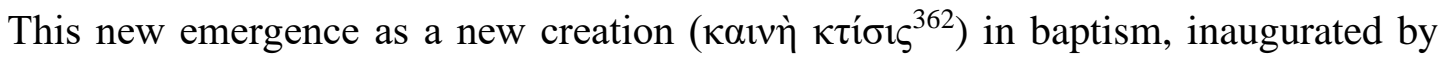
Christ's death and resurrection, has the "relative movement of moral and cosmological relationships, power and experience" into the wider society. T. Ryan Jackson, in his New Creation in Paul's Letters, argues that Paul's conception of a new creation is eschatological soteriology that has both cosmological and anthropological dimensions. ${ }^{363}$ The movement of new creation emerging from the baptism ritual into the wider society has cosmological, anthropological, and eschatological implications.

Cosmologically, Paul's vision of a new creation is a direct challenge to the imperial Roman program of reform that is communicated in cosmological terms. Given the inextricable link between physical and political orders in the ancient world, the reform program of Augustus is described as a peace offering to the world, as he brought an end to factions and civil unrest. ${ }^{364}$ Just as water is described as an essential element in the creation account, the water used in baptism is described as a crucial element in bringing forth a new creation. ${ }^{365}$ The early Christ believers challenged the reform of the imperial Romans in the use of water. Choi observes that

${ }^{362}$ Scholars have generally advocated three readings of кó $\sigma \mu \varsigma$ in Gal 6:14: 1) cosmological; 2) ecclesiological; and 3) anthropological. For the last reading, Mell Hubbard further delineates three lines of interpretation: 1) a worldly way of thinking, 2) the transience of the law, and 3) Paul's former life in Judaism; see Mell Hubbard, New Creation in Paul's Letters and Thought, SNTSMS 119 (Cambridge: Cambridge University Press, 2002), 215-16.

${ }^{363}$ T. Ryan Jackson, New Creation in Paul's Letters (Tübingen: Mohr-Siebeck, 2010).

364 Jackson, New Creation, 64; cf. Virgil, Ecl. IV.

${ }^{365}$ See Barnabas 11:1, 8, 11; Hermas, Similitudes IX. xvi. 3-6; Justin, 1 Apol. 61; Tertullian, Bapt. 12. 
one of the trademark expressions of imperial Roman rule is in its aqueduct engineering and control of water. ${ }^{366}$ By refusing to use the water collected in aqueducts and preferring the use of natural running water, ${ }^{367}$ the Christ believers are making a statement that Christ is their king, who has brought about a new creation with living water that flows from him (John 4:14; 7:3739).

Anthropologically, the communitas emerging in baptism revolutionises the social stratification of the time, because it means that all are one in Christ. No longer humans are evaluated based on external categories and distinctions that are imposed on them; instead, people find their true selves in Christ. To become like Christ is to be a true human being.

Eschatologically, Paul's conception of a new creation is an inaugurated eschaton which differs from the contemporary Qumran sect's vision of a purification ritual that seeks to restore the original creation through its observances; Paul's version serves only as a "preparation action awaiting future consummation." 368 For Paul, the new creation emerging from baptism is a historical reality that has come to pass; God's major action in Christ has already been accomplished. This heightened eschatology has caused some unwanted behaviours in Pauline communities that Paul has to correct, such as speaking in tongues and women teaching men in the assembly.

\subsubsection{Relationality}

In this final section of the ritual analysis, we discuss the special relationships that emerge from the ritual performance. The focus of our analysis is on the inclusive formula in 1 Cor 12:13. According to Michael Houseman, ritual performances do more than just recount stories; they are an enactment of "particular realities" that entail the acting out of a special relationship amongst the participants and the relational configuration that results. These special relationships have the following qualities that set them apart: agency, interaction, intentionality, affect, and accountability. In 1 Cor 12:13, baptism incorporates the participants into the body of Christ, whose members have functions and relations with other members and with the head. Our analysis is divided into three parts: enactment of special relationships, meaningful experience, and emergent effects.

The baptism ritual enacts the special relationships in the body of Christ. Although the ritual act of baptism, with immersion and emersion, does not explicitly signify a special

\footnotetext{
${ }^{366}$ Choi, "Christian Baptism," 75-91.

${ }^{367}$ See Did., 7.

368 Jackson, New Creation, 58.
} 
relationship, as in the case of a wedding ceremony where the participants evince clear signs of a new relationship, it does signify special relationships that are affected as a result of the baptism performance on the conceptual level. This is signified by the language of incorporation in 1 Cor 12:13. Earlier, we noted that the preposition eis in this passage has a local sense and that participants are thereby translated into a virtual space of Christ. Thus, it is within this virtual space afforded by baptism ritual that special relationships are enacted and actualised. The rhetorical arguments in 1 Cor 12 tell us of the enactment of these special relationships.

\begin{tabular}{|c|c|c|c|c|c|c|c|}
\cline { 2 - 8 } \multicolumn{1}{c|}{} & \multicolumn{9}{c|}{ Various gifts and members } \\
\hline One Spirit & Wisdom & Knowledge & Faith & $\begin{array}{c}\text { Miracles } \\
\text { and } \\
\text { healings }\end{array}$ & Prophecy & Discernment & Tongues \\
\hline One Body & Head & Ear & Nose & Hands & Feet & Eyes & Mouth? \\
\hline $\begin{array}{c}\text { Christ's } \\
\text { Body }\end{array}$ & Apostles & Teachers & Healers & $\begin{array}{c}\text { Miracle } \\
\text { workers }\end{array}$ & Prophets & Helpers & $\begin{array}{c}\text { Speaking } \\
\text { and } \\
\text { interpretation }\end{array}$ \\
\hline
\end{tabular}

The table shows that Paul links the various gifts of the Spirit to various positions within the body of Christ, each of which is mediated by the body analogy. In vv. 4-9 Paul lists all the known gifts of the Spirit. Then, he interrupts the discourse on the gifts by turning to the analogy of the body in vv. 14-21. He resumes the discussion of charismatic gifts in vv. 27-30, emphasising that various functions of these gifts given to different members are given by the same Spirit whose purpose is to build up the body of Christ. Note that the charismatic gifts correspond to positions in the body of Christ: wisdom is for the apostles, who have received the gospel of Christ crucified (1 Cor 1:18-31); knowledge is for teachers, who impart the divine knowledge; faith for healers who have the belief needed to heal diseases; miracles for those who perform mighty deeds of God to give testimony of the gospel; prophecy, for those who are given the divine will to see; discernment of spirits is for helpers who assist in interpretation, and tongues is for speaking in tongues. Note also that the various body parts do not correspond to the functions of these gifts and positions but only to the relative significance of these gifts and functions within the body of Christ.

The enactment of special relationships resulting from baptism gives the participant a genuinely meaningful experience; it is not mere play-acting. Houseman observes that the true meaning of such ritual performance lies in the self-validating character of ritual performance and in the informing of the participants' conventional actions. Baptism involves a degree of self-reference, meaning that the special relationships are acted out in it and allude back to it. The fable dialogue amongst the members of the body of Christ in 1 Cor 12:14-21 illustrates 
this circular movement. The dialogue begins by stressing the unity of the body $(\sigma \tilde{\omega} \mu \alpha)$ despite the protests from members to disassociate themselves from it (14-16). Then, in vv. 17-19, the dialogue emphasises the diversity of members ( $\mu \varepsilon \dot{\lambda}(\varsigma)$ ) that make up the body. ${ }^{369}$ Verse 26 concludes with the argument that the whole is in the part and the part is in the whole: "If one member suffers, all suffer together; if one member is honoured, all rejoice together." Commenting on the passage, John Chrysostom also notes the theme of unity-diversity by employing a chiastic structure in his argument: ${ }^{370}$

a. diversity: "If there were not among you great diversity"

b. unity: "ye could not be a body; and not being a body, ye could not be one"

'b. unity "if ye were all equal in honor"

'a diversity: "ye were not a body; and not being a body, ye were not one"

Classical literature often employs the trope of an internal dialogue amongst the members of the body to evaluate one's behaviours in relation to the city or world in which one dwells. For instance, Livy narrates a story of human members who rebel against the belly, perceiving it as incompetent. The members thus refuse to give food to the belly, which leads to the malnourishment of the whole body (2.32 9-10). The belly nourishes the rest of the body with blood, just as the body feeds the belly with food (2.32 12). Likewise, if a citizen in a city suffers harm or injury, then the whole city also suffers (Plato, Resp. 462B-E; Seneca, Ira 2.31.7; Marcus Aurelius, Med. 12.35-26). Thus, the special relationships enacted by baptism in the form of the body figure become the point of self-reference in assessing behaviours subsequent to the baptism ritual.

Finally, the meaningful enactment of special relationships results in a process of recontextualization that involves two levels: the integration of disparate elements and the "specific idiom indexing a privileged context." This recontextualization results in a change of behaviours amongst the participants, as the special relationships enacted in the ritual become their ongoing reality. The baptism ritual brings together contrary modes of social relationships, as illustrated by the two pairs of social categories: Jew or Greek, slave or free. The ethnic division reflects two groups of people with multiple enmities towards each other and divided

${ }^{369}$ Some suggest that the figure of the body employed by Paul is directed against factionalism or individualism. See Conzelmann, 1 Corinthians, 212; Mitchell, Paul and the Rhetoric, 157-64. M. L. Soards observes that Paul's point is "unity dominates diversity and makes diversity genuinely meaningful and constructive"; 1 Corinthians: New International Commentary (Peabody, MA: Hendrickson, 1999), 263. These observations are correct insofar as they only focus on one aspect of Paul's point in the passage. Instead of perceiving Paul's point falling on either unity or diversity, we should understand Paul as trying to hold the opposite poles of unity and diversity together. The exchange between $\mu \dot{\varepsilon} \lambda \circ \varsigma$ and $\sigma \tilde{\omega} \mu \alpha$ throughout the pericope attests to this; Paul does not emphasise members at the expense of the body or vice versa.

${ }^{370}$ Chrysostom, Homilies on the Epistles of Paul to the Corinthians XXX.5 (NPNF 12/12: 178). 
by their values, practices, and religions. The second pair - the social strata in Corinth - reflects the wider social system of the Roman Empire, whose social structure can be visualised as a large pyramid with a tiny elite class at the top and with lower strata at the bottom consisting of slaves (servi), freepersons (liberti), and freeborn (ingenui). ${ }^{371}$ Under normal circumstances, these social groups would not have interacted outside of established social customs, but baptism provides an experiential ground for them to relate to one another in the body of Christ. The symbolism of the body of Christ emerging from baptism becomes a specific idiom signifying the special relationships, that all baptised ones are members of Christ's body. This new reality takes on a life of its own after the baptism ritual; it is a new reality by which the Corinthians should live.

This ritual analysis has demonstrated that the baptism ritual is a ritual performance that has a superhuman agency, the Spirit, whose logical entailments include the Christ myth and sanctity discourse, resulting in intervening in human reality (Christ's sphere), eschatological emergence, and the special relationships in Christ's body.

\subsection{Conclusion}

This chapter has examined the question of how the baptism ritual facilitates the process of union with Christ by using the performance theories that explain the process by which the participants have a transformative experience, defined as the encounter with the divine and the reconfiguration of human reality. We first established that baptismal allusions in Paul's writings (1 Cor 6:11; 12:13; Gal 3:27-28; Rom 6:3-8) denote the ritual background by offering three lines of evidence: the baptism tradition, performative indicators, and the metaphor predicate. We then recovered the whole apparatus of the ritual baptism ceremony by using the method of filling gaps by drawing on analogous baptismal practices across the wide spectrum of the early Christ movement outside the Pauline community. After that, we situated the baptismal performance in the wider social and cultural context, arguing that the former pertains to the issue of orthodoxy, whose articulation relates to the success or failure of ritual performance, and the latter to the various motifs incorporated into the ritual as frames of reference to facilitate the transformative experience. Finally, the analysis of ritual performance demonstrated that the baptism ritual facilitates the process of union with Christ through the divine agent, the presence and the mediation of the Spirit, the re-enactment of the Christ myth in the ritual performance that identifies the participant with the Christ event, the manifestation

${ }^{371}$ Horrell, The Social Ethos, 64-73. 
of holiness that sanctifies the participant, the transportation into Christ's sphere that transfigures human reality and causes the emergence of a new social reality that has an impact on the wider society, and the re-enactment of special relationships in Christ's body, whose members use self-reference for their new existence. 


\section{Chapter 3}

\section{The Lord's Supper as a Ritual Performance}

\subsection{Introduction}

This chapter continues the overall argument by suggesting that Paul's eucharistic texts are also ritualistic in nature. To establish this argument, it is first necessary to show that the two relevant passages in 1 Corinthians reflect the actual practices of the community and are not simply theological discussions on the nature of the Eucharist. This latter opinion has recently been suggested by a number of scholars. Therefore, the first step in the chapter is to show that this is not the best characterisation of the material in Corinthians. Rather, and especially with the material in 1 Cor 11:17-34, it is more natural to read this as an account of the ritual words and form of the eucharistic rite. Having established this, the discussion then employs insights from ritual theory to explicate the participatory aspect of the rite for the Corinthians engaging in the ritual practice described by Paul. This discussion demonstrates that the eucharistic rite as a ritual practice facilitates participation in Christ through the transformative encounter with God in the sacrificial meal, which transfigures the status of the participants in relation to one another and to God.

\subsection{Ritual text}

The most explicit references to the Lord's Supper in Paul's corpus are found in 1 Corinthians: 10:14-22 and 11:17-34. Unlike the baptismal allusions in Paul's writings, which are sparse and highly symbolic, the Lord's Supper material clearly refers to the meal ritual of the nascent Christ religion and reflects aspects of its ritual practice. There is an issue that is raised with the relation of the institutional narrative in 11:23-26 to the communal meal in 10. The earlier scholarship was predisposed to describe the institutional narrative as a liturgical text used by the primitive Christ community. ${ }^{372}$ By contrast, there is a new emerging consensus amongst scholars that the Lord's Supper tradition was not employed as part of liturgical prayer until the late fifth century. ${ }^{373}$ The narratives are catechetical material that provides a theological

372 Jerome Murphy-O'Connor, "Eucharistic and Community in First Corinthians," in Living Bread, Saving Cup, ed. R. Kevin Seasoltz (Collegeville, MN: The Liturgical Press, 1982), 1-30; Heinz Schürmann, Eine quellenkritische Untersuchung des lukanischen Abendmahlsberichtes LK 22, 7-38, II Teil (Aschendorff: Münster, 1955), 144n475.

${ }^{373}$ Andrew B. McGowan, “'Is There a Liturgical Text in This Gospel?’ The Institution Narratives and Their Early Interpretive Communities," JBL 118, no. 1 (1999): 73-87; Paul F. Bradshaw, Eucharistic Origins, ACC 80 (London: SPCK, 2004), 11; and Henk Jan de Jonge, "The Early History of the Lord's Supper," in Religious Identity and the Invention of Tradition, ed. Jan Willem van Henten and Anton Houtepen (Assen, The Netherlands: Royal Van Gorcum, 2001), 209-37. 
reflection on the eucharistic meal, such as identifying bread and cup with the death of Jesus ( $\dot{v} \dot{\varepsilon} \rho \dot{v} \mu \tilde{\omega} v)$. Some take the argument further, claiming that "the Last Supper story was not related during the Eucharistic meal." 374 Although emerging scholarship deems the institution narrative as not being part of early Christian liturgy, this study argues that it still stands in close relationship with the communal meal of the nascent Christ religion.

\subsubsection{The eucharistic ritual and the institution narrative}

According to G. A. M. Rouwhorst, the institution narrative is not recited in the same type of communal meal reflected in 1 Cor 10:16-17, Luke 22:15-19a (Western text), and Did.9-10.375 De Jonge adds that it even departs from the communal meal type cited in 1 Cor $11 .{ }^{376}$ Thus, the institution narrative cited in 1 Cor 11 is not related to the eucharistic meal; however, upon close inspection we find a common tradition behind all these eucharistic types, although different interpretations are associated with each.

First, the basic ritual action of blessing the bread and cup remains the same throughout all these eucharistic accounts, although some have a cup-bread sequence. This is shown in the parallelism of statements regarding the bread and cup through relative or participial clauses or the same sentence structure:

\begin{tabular}{|c|c|c|}
\hline & Bread & Cup \\
\hline 1 Cor $10: 16-17$ & $\tau o ̀ v ~ \alpha ̋ \rho \tau o v ~ o ̈ v ~ \kappa \lambda \tilde{\omega} \mu \varepsilon v$ & 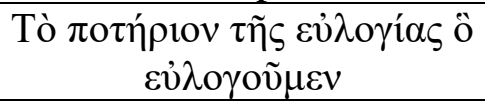 \\
\hline $\begin{array}{l}\text { Luke 22:17-19 } \\
\text { (Western Text) }\end{array}$ & 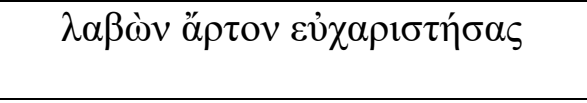 & 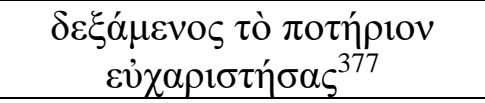 \\
\hline Did. $9.2-3$ & 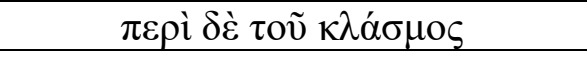 & 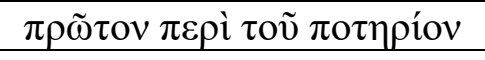 \\
\hline 1 Cor $11: 24-25$ & 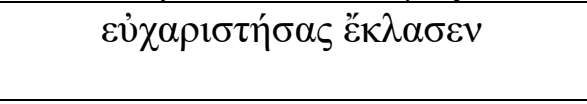 & 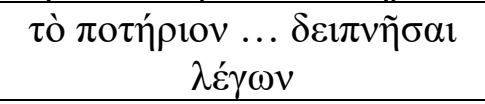 \\
\hline Mark 14:22-24 & 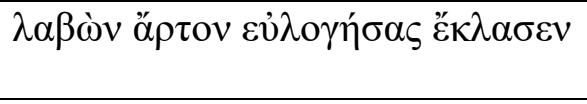 & 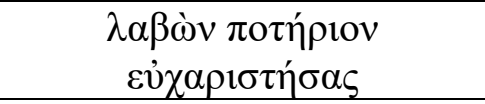 \\
\hline Matt 26:26-28 & 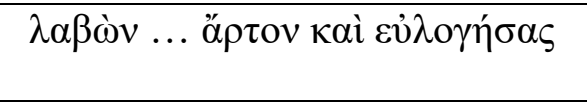 & 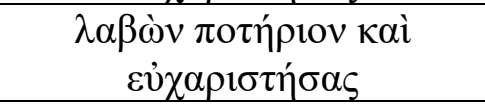 \\
\hline
\end{tabular}

${ }^{374}$ Valeriy A. Alikin, The Earliest History of the Christian Gathering: Origin, Development and Content of the Christian Gathering in the First to Third Centuries, SVC 102 (Leiden: Brill, 2010), 115.

375 G. A. M. Rouwhorst, De viering van de eucharistie in de vroege kerk (Utrecht: Katholieke Theologische Universiteit, 1992), 8-18.

376 de Jonge, "Early History," 211 n9.

377 There is a text-critical problem in Luke 22:19-20, which has longer and shorter versions. The longer version of the institution narrative contains two cups: one is distributed before the bread and the other shared after the meal ( $\mu \varepsilon \tau \grave{\alpha}$ iò $\delta \varepsilon \imath \pi v \tilde{\eta} \sigma \alpha \imath)$. Mikael Winninge gives several explanations for the textual variance: "The occurrence of two cups can easily be understood both in a Jewish context with festive meals and in accordance with Greco-Roman practice at the symposia. However, at a later stage it might have seemed odd for Christian copyists who had a very clear idea of what the celebration of the Eucharistic must be like (one cup). An alternative, but less plausible, explanation of the short text could be that it is an abbreviation in order to save space with the 


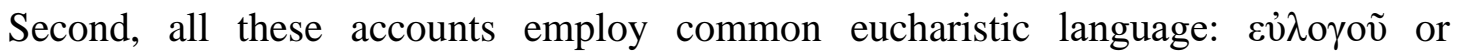

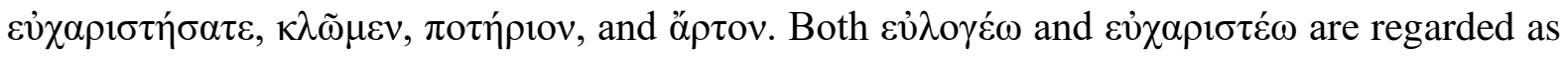
synonymous for denoting the actions of blessing and thanksgiving. ${ }^{378}$ Commentaries have noted that the former derives from the Aramaic blessing ${ }^{379}$ or the Hebrew equivalent of whereas Paul would use the latter to reflect his Hellenistic audience. ${ }^{381}$ The term $\kappa \lambda \alpha \dot{\alpha} \omega$ or $\kappa \lambda \alpha ́ \sigma 1 \zeta$ appears in Synoptic Gospel accounts of the institution narrative (Matt 26:26; Mark 17:22; Luke 17:22), Paul's letter (1 Cor 11:26-28), and in the Gospel of John (6:34-58). Thus, breaking the bread becomes an important element of the eucharistic ritual, acquiring enough

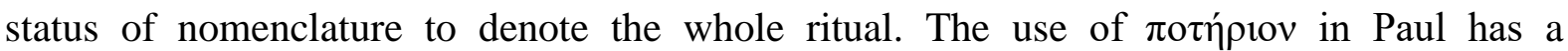
Septuagintal Greek influence and has been shaped by Jewish background (cf. Joseph and Aseneth 8.11). ${ }^{382}$ It must refer to the eucharistic chalice, as confirmed by other early Christian literature. ${ }^{383}$

Thirdly, all these eucharistic accounts have an eschatological emphasis except for 1 Cor 10:14-22, unless we take 1 Cor 10:14-22 and 1 Cor 11:17-34 as together referring to the same eucharistic meal, with the former being the description of the ritual performance and the latter a cult narrative accompanying the ritual. We argue that such is the case with these two eucharistic references in 1 Corinthians and demonstrate below how they are connected, but for now we discuss the eschatological outlook in all the other eucharistic accounts.

assumption that the readers or the intended audience anyhow knew by heart what followed (in the liturgy)"; Mikael Winninge, "The Lord's Supper in 1 Cor 11 and Luke 22: Traditions and Development," in The Eucharist-Its Origins and Contexts: Sacred Meal, Communal Meal, Table Fellowship in Late Antiquity, Early Judaism and Early Christianity, Volume I, ed. David Hellholm and Dieter Sanger (Tübingen: Mohr Siebeck, 2017), 587-88. At any rate, this textual variance shows that the community practice has an impact on the textual tradition and that the shape and form of the Lord's Supper was fluid in the earliest decades of the Christ religion.

378 Jerker Blomqvist and Karin Blomqvist, "Eucharist Terminology in Early Christian Literature: Philological and Semantic Aspects," in The Eucharist-Its Origins and Contexts: Sacred Meal, Communal Meal, Table Fellowship in Late Antiquity, Early Judaism and Early Christianity, Volume I, ed. David Hellholm and Dieter Sanger (Tübingen: Mohr Siebeck, 2017), 399.

${ }^{379}$ Anders Eriksson, Traditions as Rhetorical Proof, 107n156.

${ }^{380}$ Joseph A. Fitzmyer, First Corinthians: A New Translation with Introduction and Commentary, AB 32 (New Haven: Yale University Press, 2008), 437. See also LXX Jdt 8.25; 2 Macc 1:11; 10:7; Philo, Spec 2.33, 204; 3.1, 6; Josephus, A.J. 1.10.5, 193.

381 Winninge, "The Lord's Supper," 598.

382 Blomqvist and Blomqvist, "Eucharist Terminology," 415.

383 Justin, Dial. 41.3; Acts of John 9; Acts of Thomas 158; Did. 9.1. 


\begin{tabular}{|c|c|}
\hline & Eschatological Outlook \\
\hline $\begin{array}{l}\text { Luke 22:18 (Western } \\
\text { Text) }\end{array}$ & 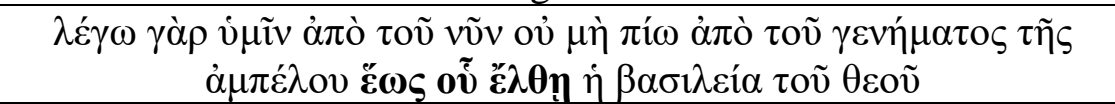 \\
\hline Did. 10:6 & 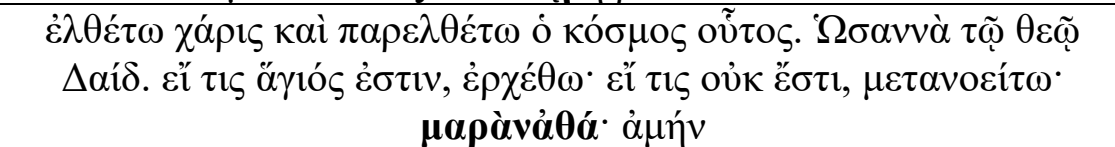 \\
\hline 1 Cor $11: 26$ & 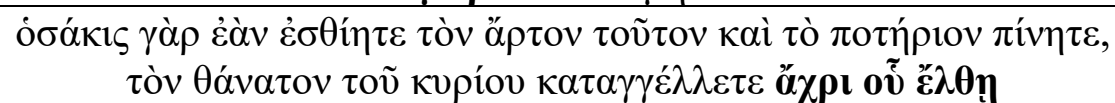 \\
\hline Mark 14:25 & 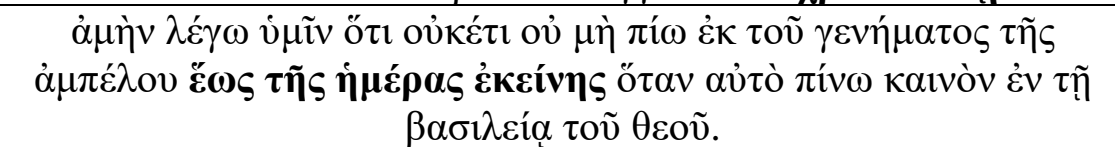 \\
\hline Matt 26:29 & 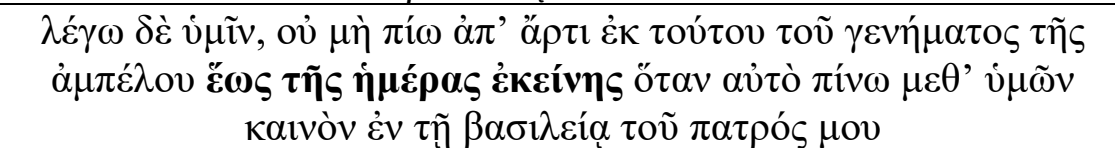 \\
\hline
\end{tabular}

Several observations can be made. The accounts of the communal meal in the Synoptic Gospels have Jesus telling his disciples that there will be a new banquet in God's kingdom, set in the indefinite future, in which they will drink a new wine together. Paul's account of the communal meal also expects the Parousia of Jesus. Both are future-oriented, but the focus for the former

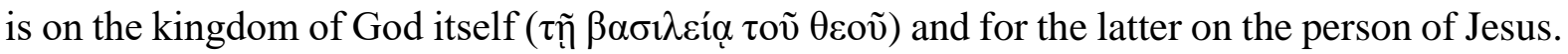
This indicates that the Lord's Supper tradition preserved in the Synoptic Gospels has the following components:

1. The pre-resurrection memory of Jesus's practice of holding meals with both his disciples and outsiders, anticipating the coming of the kingdom of God.

2. The conviction that Jesus's death and resurrection inaugurate a new age in which the practice of common meals will be renewed.

3. The memory of the last common meal with Jesus before his arrest and crucifixion. ${ }^{384}$

The line of tradition preserved in 1 Cor 10 and 11 has the following presuppositions:

1. The message of the gospels is centred on the crucified and resurrected Jesus.

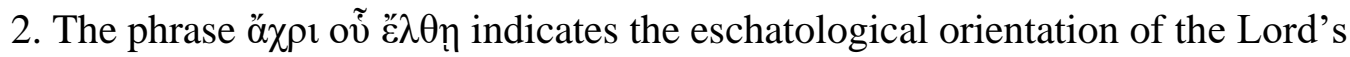
Supper, whose vision can be elucidated by Paul's description of Jesus's resurrection and his coming again in the future in 1 Cor 15:20-28.

3. The memory of the final supper Jesus had with his disciples the night he was delivered up.

${ }^{384}$ Dietrich-Alex Koch, "The Early History of the Lord's Supper: Response to Henk Jan de Jonge," in Religious Identity and the Invention of Tradition, ed. Jan Willem van Henten and Anton Houtepen (Assen, The Netherlands: Royal Van Gorcum, 2001), 250. 
4. The understanding that Jesus's death is vicarious and identifying it with the bread and cup during the eucharistic meal.

Despite the different elements contained in these two strands of tradition, we see two elements converge: the memory of the Last Supper and the understanding that the meal ritual prefigures the consummation of God's kingdom. Finally, although the Didache's account of the communal meal does not explicitly contain an eschatological element, the cry of maranatha, which occurs in Did. 10.6, is included in the meal ritual, serving as a concluding prayer to the whole ceremony and bringing the communal meal to a climatic end. The invocation of maranatha in the Corinthian community is attested as early as the first century; it formed part of their worship. Therefore, it should be assumed that it was widely used in many primitive ekklēsia when concluding the meal ritual.

We have demonstrated that, despite some different elements in each type of eucharistic meal, there remain a core tradition underlying all of them; to wit, the parallel statements for the respective blessings of bread and wine, the common stock of a eucharistic vocabulary, and the shared eschatological outlook of the meal ritual. Given the common tradition underlying all these meals, the argument that the institution narrative is not related to the communal meal simply cannot be substantiated.

\subsubsection{The eucharistic ritual and cultic narratives}

Having established that the institution narrative is related to the communal meal alluded to in 1 Cor 10 , we need to define more precisely how they are related. As mentioned above, we argue that the institution narrative functions as a cultic narrative that informs and accompanies the performance of the eucharistic ritual. Therefore, although the institution narrative was not part of the eucharistic liturgy in the first few generations of the Christ religion, when it had a didactic function, it is still connected with the eucharistic ritual. We demonstrate this connection through contextual clues, isolation of performance elements, and an analogous pattern in the Greco-Roman context.

Contextually, the institution narrative cited in 1 Cor 11 belongs to the wider context of the discussion on the ordo of worship in the Corinthian community. The immediate context surrounding 1 Cor 11:23-26 is the reference to the communal meal in 1 Cor 10:16-17. The catechetic formula in 1 Cor 11:23b-25 corresponds to the eucharistic blessings of bread and wine in 1 Cor 10:16-17: 


\begin{tabular}{|c|c|c|}
\hline & 1 Cor $11: 24-25$ & 1 Cor $10: 16-17$ \\
\hline Bread & 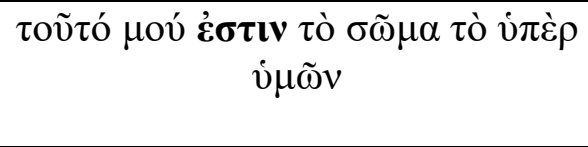 & 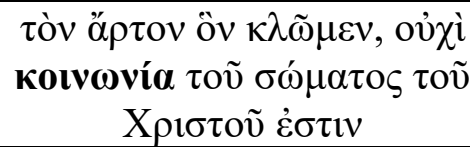 \\
\hline Wine & 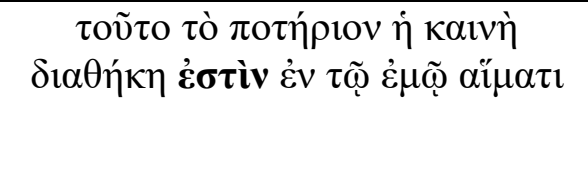 & 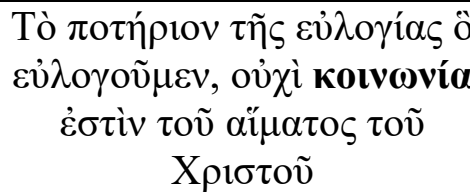 \\
\hline
\end{tabular}

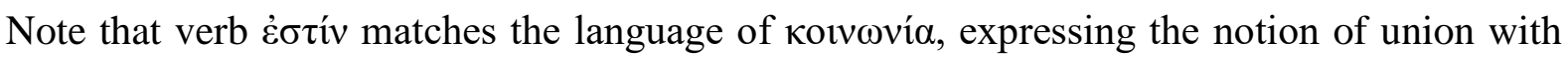
Christ. The former, from the vantage point of the cult founder, espouses the idea that the bread and wine in the ritual identify with his very life; the latter, from the perspective of the participants, expresses the understanding that partaking of the bread and wine is tantamount to partaking of the life of Jesus. ${ }^{385}$ To place 1 Cor 11:23-26 in the wider context of First Corinthians, it is located within a wider discussion of liturgical abuses that runs from chapters 8 through $14 .{ }^{386}$ Chapter 8 commences the discussion of food offered to idols; Paul mentions that some Corinthians partake of meat in the temple, matching the language of the table of demons in 1 Cor 10:21, which presupposes that some liturgical taboos have been violated by the Corinthians. Although chapter 9 does not explicitly relate to liturgical issues, it is noted that Paul makes an analogy between someone serving in the temple and the one commissioned by the Lord to proclaim the gospel (9:13-14; cf. Num 18:8, 31; Deut 18:1-13) The same word for

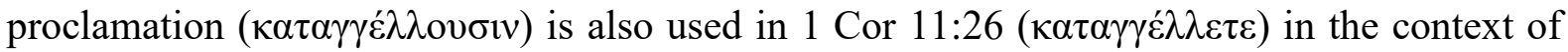
liturgical proclamation of Jesus's death. Thus, the issue of apostolic privileges has some kind of liturgical implication, although Paul does not state it clearly. In chapter 10 Paul's Midrashic reading of the Exodus story recalls the ritual of baptism and the Lord's Supper to establish the argument that, regardless how much divine grace one receives, it will not shield them from the consequences of infidelities and immorality. In chapter 11, Paul discusses the veiling of women during worship and the abuses occurring during the celebration of the Lord's Supper. Finally, from chapters 12 to 14 Paul tackles the abuses of varieties of charismatic gifts manifested at worship, especially the gift of speaking in tongue. Therefore, the institution narrative is nested within the broader discussion of worship behaviour, and as such it is closely related to the eucharistic meal.

Another point of contact between the institution narrative and the cultic meal is the performative language in the narrative that serves as an inkling for the indexical gestures in the

${ }^{385}$ See section 3.5.3 Transformation: Virtuality and historical emergence.

${ }^{386}$ Morales, "Baptism and Union," 170. 
actual ritual performance. In chapter 2 we have discussed the performative indicators of a ritual include the speech act, the ritual action, and the role of the human body in the efficacy of performatives and the establishment of a social order. We combine this observation with Christian Strecker's observations of the relationship between ritual and text, of which three are applicable to 1 Cor 11:23-26, that is,

1. Ein Text enthält Anweisungen zur Ausführung eines Rituals.

2. Ein Text berichtet oder konstatiert den Vollzug eines Rituals.

3. Ein Text beschäftigt sich mit der Bedeutung, Funktion oder rechten Durchführung eines Rituals. ${ }^{387}$

Thus, based on these criteria we can isolate the following ritual elements within the narrative institution:

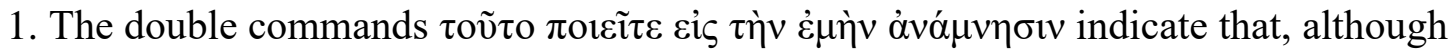
it is difficult to establish with certainty that it can be traced back to the historical Jesus, the celebration of the Lord's Supper originates from a divine command. As such, that command needs to be put into practice in the form of a meal ritual.

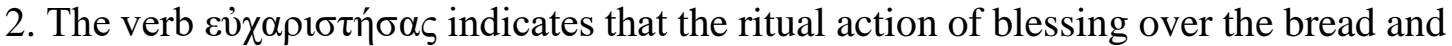
wine is a form of thanksgiving. Did. 9-10 preserves one of the earliest forms of the eucharistic prayer. Because the form and concept of the Lord's Supper underlie both Paul and the Didache, we can surmise that that form of prayer was used in the Corinthian community. ${ }^{388}$

3. It includes the interpretation of the meal ritual that shows the stamp Paul left on the received tradition. This is evinced by the insertion of the phrase $\tau$ ò $v \pi \dot{\varepsilon} \rho \dot{v} \mu \tilde{\omega} v$ after

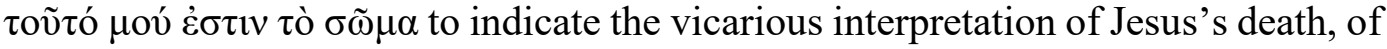
the word $\dot{\eta} \kappa \alpha \iota v \grave{\eta}$ to $\delta 1 \alpha \theta \dot{\eta} \kappa \eta$ signifying the fulfilment of Jeremiah's prophesy, and

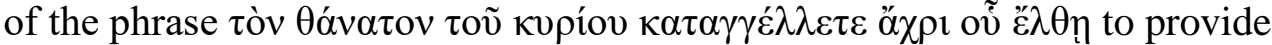
eschatological emphasis.

The identification of these ritual elements strengthens the argument that the institution narrative is inextricably related to the eucharistic ritual.

Finally, the relationship between the institution narrative and communal meal can be further elucidated by examining the relationship between cult and ritual and myths and foundational stories in antiquity, when recasting an old story in a new version until it reached a final stage of crystallisation constitutes, alongside cults and rituals, one of the primary elements of a community. An illumining example of this is how the lyrics of Pindar draw on the mythical past of the Homeric story and recast it to present the idea of Pan-Hellenism. The

${ }^{387}$ Strecker, Die liminale Theologie, 78.

388 Alikin, Earliest History, 108-13. 
cults and ritual practices of the Pan-Hellenic sanctuaries correspond to the performances of the Homeric epic. Another example is Virgil's Aeneid, in which the founder of Rome is linked with the story of Troy from Homer's Iliad, which became the founding story of Rome. Augustus made use of Virgil's epic by connecting himself with the story of Rome's founding through the consecration of the Ara Pacis, the new Alter of Peace, accompanied by a festival procession. This pattern of creating a new foundational story performed in ritual is evident in 1 Cor 11:23-26. It has been noted that the formula "in the night in which he was handed over ( $\pi \alpha \rho \varepsilon ́ \delta \omega \kappa \varepsilon v) "$ alludes to the Greek text of Isa 53:6: "The Lord handed him over for our sins"

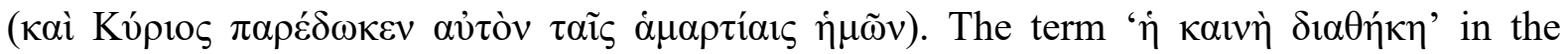
catechistic formula refers to Jer 31:31, Jer 32:40 (cf. Zech 9:11), and the exodus story of the founding of the Israelite nation (Ex 24:8).

Furthermore, if we read 1 Cor 11:23-26 together with 1 Cor 5:6-8, 10:1-5, and 12:13, we see that Paul is recasting the institution narrative in the direction of the Passover experience. We take 1 Cor 5:8 as a point of departure, wherein Paul writes that "Let us, then, celebrate the feast ... ." The feast refers to the Passover meal that Paul makes use of metaphorically previously in verses 6-7. Paul admonishes his audience to cleanse themselves of sexual immorality, specifically fornication. After having compared the practice of getting rid of old leaven in preparation of Passover meal with sexual immorality, Paul exhorts the Corinthians to celebrate the feast, for their Passover lamb, Christ, has been sacrificed. Some commentators see this as Christian version of Passover meal or the Lord's supper. Many others, however, view the feast as a celebration of whole Christian living, not an allusion to the Lord's Supper ritual. ${ }^{389}$ Granted, the immediate context shows that Paul is applying Passover ritual practice as a metaphor with moral implications for the Corinthians. Nevertheless, Paul's juxtaposing the account of Passover story of deliverance of Israelites from Egyptians bondage and how Moses guided them through the red sea in a cloud with reference to the Lord's Supper in 1 Cor 10:1-22, suggests a connection is made between Passover meal and the Lord's Supper. ${ }^{390}$ In fact, Paul in verse 6 and 11 writes that the Passover story along with the story of Israelites living in the wilderness serve as an example or type ( $\tau$ $\pi 01$ and $\tau v \pi ı \tilde{\omega} \varsigma$ ) for his audience. This demonstrates that Paul is actualising Passover story for the contemporary experience of Corinthian communities. ${ }^{391}$ Thus, the spiritual ( $\left.\pi v \varepsilon v \mu \alpha \tau 1 \kappa o ́ v\right)$ food, drink, and rock in verse 4

${ }^{389}$ David E. Garland, 1 Corinthians. Baker Exegetical Commentary on the New Testament (Grand Rapids, Mich.: Baker Academic, 2003); Perkins, First Corinthians, 93; Thiselton, The First Epistle to the Corinthians, 405-06.

${ }^{390}$ See Fitzmyer, First Corinthians, 379 for argument to view 10:1-13 and 10:14-22 as a unit.

${ }^{391}$ Ibid.,379. 
correspond to the current ritual practices of Corinthian communities, namely, baptism and the Lord's Supper, connected by a conjunction $\delta$ ó $\pi \varepsilon \rho$ in verse 14; and in the ensuing verses 15-22 Paul applies the lessons drawn from the Passover story to the contemporary Corinthians in proper way of celebrating the Lord's Supper.

Several observations can be made regarding the relationship between Passover meal and the Lord's Supper. First, Paul does not equate or insinuate that the Lord's Supper is the Passover meal in 1 Corinthians. Second, the connections are made between these two rituals via Paul's midrashic reading of Passover story and its ritual elements: the lamb slaughtered on the first day of feast of Unleavened Bread (Exod 12:14-20) corresponds to Christ, the new paschal lamb (1 Cor 5:7) for expiation of sins, the water miraculously flowed from the rock to the spiritual drink, the Cup, in the Lord's Supper (1 Cor 10:16, 21), the unleavened bread to

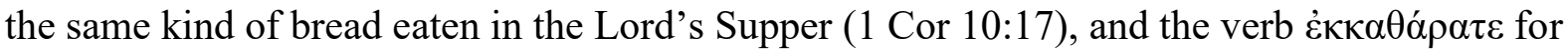

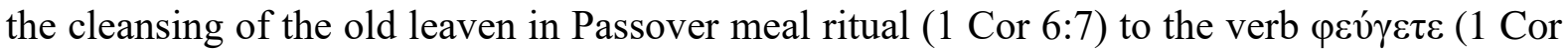
10:14) to signify abstaining from participating in idol worship as a purification act before partaking of the Lord's Supper meal. Finally, Paul's linking the Lord's Supper with that of Passover meal underscores that both rituals serve as a founding rite for the creation of a new community.

Through this literary creation, Paul is legitimising the cult of the Kyrios Christ by anchoring it in the traditional language of the founding story of Israel, even as he replaces that story with a new narrative centred on the death of Jesus.

\subsection{Ritual Form}

Having established that 1 Cor 10:14-22 and 11:17-34 are the ritual texts on which this study carries out ritual analysis, we can begin the first step in that analysis, which is to reconstruct the ritual form of the Lord's Supper. This reconstruction paves the way for the analysis of the ritual functions below; each element is used to analyse the various ritual functions that comprise the overall transformative experience of the divine in the ritual. Since these texts do not detail the full ceremony of the meal ritual, this study employs the filling-the-gaps method by referring to parallel texts, as was the case with baptism in chapter $2 .{ }^{392}$ The references to the Lord's Supper in 1 Corinthians serve as our point of departure in reconstructing the ritual (10:14-22; 11:17-34; cf. 5:3-13; 9:13-14; 10:1-5; 12:13). This is supplemented by the ritual words and actions in the institution narrative in the Synoptic Gospels (Matt 26:20-29; Mark

${ }^{392}$ See the discussion in chapter 2, section 3: Ritual form. 
14:17-25; Luke 22:19-20). References to the Didache, Justin Martyr, and other early Christian literature further supports and fills in some gaps in our knowledge of the ritual in the nascent Christ movement.

We acknowledge that the practice of the Lord's Supper varied from community to community. Nevertheless, there are core elements that underline all the practices of the Lord's Supper that can aid us in our reconstruction effort. These core elements are the basic ritual actions and words accompanying the Lord's Supper, as have shown above in examining the different communal meal types found in Luke 22:17-19 (Western text), Did 10.6, 1 Cor 10:1617; 11:24-25, Mark 14:22-24; Matt 26:26-28. Using various sources from different periods does raise the issue of temporal anachronism, to which we respond that, although there is a one- or two-generation gap between Paul's addresses in Corinth and the Christ religion communities after the apostolic period, from the broad perspective of history, both belong to the period before the full blossoming of theological and sacramental development after the third century; thus the differences in practices amongst the various communities in this early period are negligible in terms of the core eucharistic elements.

\subsubsection{Ritual actions}

There are four major actions accompanying the Lord's Supper ritual: the consumption of bread and drink, the blessings of the bread and drink, the breaking of the bread, and the proclamation. The terms $\varphi \alpha \gamma \varepsilon \tilde{\imath} v, \pi i ́ v \eta \tau \varepsilon$, and $\delta \varepsilon ı \pi v \tilde{\eta} \sigma \alpha$ signify the action of consuming at the Lord's Supper ritual. Some think that the dual terms "meal" and "eating" are merely a pleonasm in 1 Cor

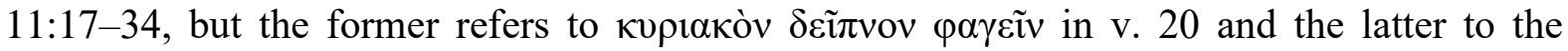

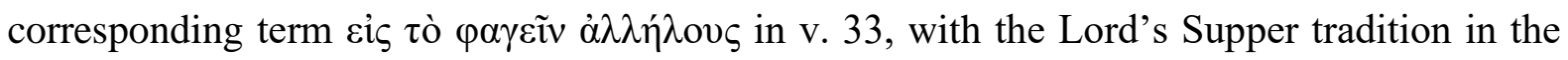

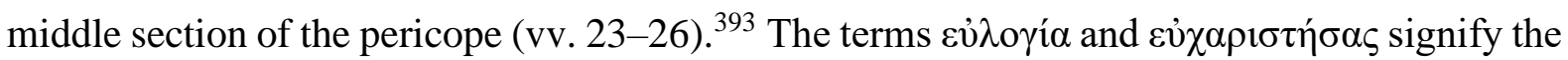
blessings over the food and drink, with a possible consecratory prayer to God (cf. Did. 9 and

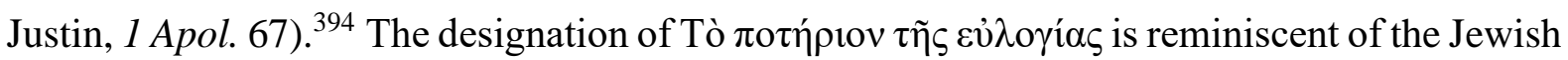

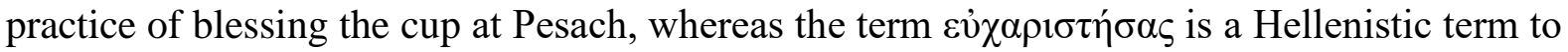
differentiate the meal ritual practiced in the Christ movement from the one used in Judaism. ${ }^{395}$ The term हैא $\lambda \alpha \sigma \varepsilon v$ denotes the action of distributing and sharing the loaf in the ritual. The verb occurs in the meal context in the New Testament corpora from which Luke derives the term

${ }^{393}$ Gerd Theissen, The Social Setting of Pauline Christianity, trans. John H. Schütz (Edinburgh: T\&T Clark, 1982), 153.

${ }^{394}$ Leonard Goppelt, Theology of the New Testament 2: The Variety and Unity of the Apostolic Witness to Christ (Grand Rapids: Eerdmans, 1982), 147-49.

${ }^{395}$ Eriksson, Traditions as Rhetorical Proof, 108. 
"eucharistic" to designate the meal ritual (Luke 24:20; Acts 2:46; 27:35; Mark 8:6, 9; 14:22;

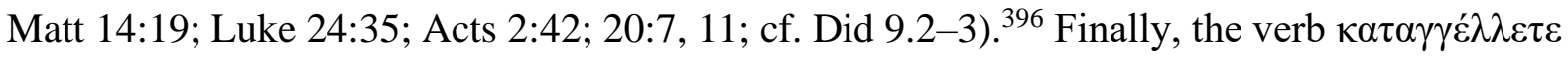
either denotes some form of verbal proclamation accompanying the ritual in the form of homily or cultic narrative ${ }^{397}$ or the ritual performance itself. 398

Regarding the sequence of ritual actions, most scholars agree that the phrase $\mu \varepsilon \tau \grave{\alpha}$ $\delta \varepsilon ı \pi v \tilde{\eta} \sigma \alpha_{\iota}$ intimates that the blessing of the bread and drink are separated by a meal proper, in keeping with both Jewish and Greco-Roman meal practices (cf. "Table Talk," Moralia 612F). ${ }^{399}$ Hans-Josef Klauck raises the objection that, if some Corinthians came late they would only receive the ritual cup; rather, there will be a full meal followed by the twofold rite of bread and wine. ${ }^{400}$ Klauck's premise is predicated upon the temporal aspect of $\pi \rho 0 \lambda \alpha \mu \beta \alpha ́ v \varepsilon ı v$ and $\dot{\varepsilon} \kappa \delta \varepsilon ́ \chi \varepsilon \sigma \theta \alpha \mathrm{l}$, if indeed there is such a temporal connotation associated with the terms. ${ }^{401}$ Thus, the sequence of ritual action in the Corinthian community likely followed a threefold ordo: the meal began with a blessing of the bread, followed by the meal proper, and blessing of the cup after the meal.

\subsubsection{Ritual actors}

Citing the Lord's Supper tradition that has been handed down to him, Paul indicates that Jesus is the main actor in the Lord's Supper narrative when he relates the account in which Jesus instituted the meal ritual on the night he was betrayed. Besides Jesus as the celebrant of the meal ritual depicted in the institution narrative, others fulfil the celebrant role in the absence of

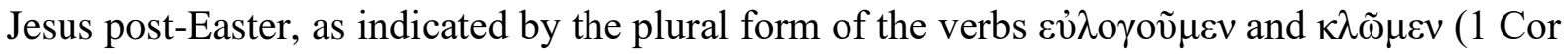
10:16). We detail the nature and function of the celebrant below, but for now it is enough to say that Paul is referring to the paterfamilias of the house where the Corinthians assembled for

\footnotetext{
${ }^{396}$ Fitzmyer, First Corinthians, 437.

${ }^{397}$ Victor C. Pfitzner, "Proclaiming the Name: Cultic Narrative and Eucharistic Proclamation in First Corinthians," LTJ 25 (1991): 15-25.

${ }^{398}$ Beverly Roberts Gaventa, “'You Proclaim the Lord's Death': 1 Corinthians 11:26 and Paul's Understanding of Worship," RevExp 80, no. 3 (1983): 377-87.

399 Theissen, The Social Setting, 152; A. Andrew Das, "1 Corinthians 11:17-34 Revisited," CTQ 62, no. 3 (July 1998): 193-97; Otfried Hofius, "The Lord's Supper and the Lord's Supper Tradition: Reflections on 1 Corinthians 11:23b-25," in One Loaf, One Cup: Ecumenical Studies of 1 Cor 11 and Other Eucharistic Texts: The Cambridge Conference on the Eucharist August 1988, ed. B. F. Meyer (Leuven: Peeters Press, 1993), especially 83-88; Collins, The First Corinthians, 431.

${ }^{400}$ Hans-Josef Klauck, "Present in the Lord's Supper: 1 Corinthians 11:23-26 in the Context of Hellenistic Religious History," in One Loaf, One Cup: Ecumenical Studies of 1 Cor 11 and Other Eucharistic Texts: The Cambridge Conference on the Eucharist August 1988, ed. B. F. Meyer (Leuven: Peeters Press, 1993), 65-66.

${ }^{401}$ David E. Garland, 1 Corinthians: Baker Exegetical Commentary on the New Testament, ed. Robert W. Yarbrough and Robert H. Stein (Grand Rapids: Baker Academic, 2003), 546.
} 
worship. ${ }^{402}$ The other actors in the ritual include the participants who are the partakers of bread and drink. The participants are required to take the following precautions before the meal, lest they suffer condemnation and death:

1. Removal of any moral contamination amongst the congregation, especially the sin of sexual immorality (1 Cor 5:3-13; cf. 6:9-11).

2. Total allegiance to Christ by refraining from participation in pagan sacrifices (1 Cor 10:14-22; cf. 10:1-5)

3. Self-examination and discerning before partaking of the bread and wine (1 Cor 11:28-34).

The risks involved in celebrating the Lord's Supper are great; Paul admonishes his readers to have a proper disposition when approaching the table of the Lord.

\subsubsection{Ritual places}

In earlier scholarship, it was assumed that early Christ associations met exclusively in private houses owned by an affluent benefactor. There are reasonable grounds to make that argument, given the evidence from Paul's various letters that gives that impression. For instance, Paul sometimes mentions groups of believers in someone's house towards the end of his letters (1 Cor 16:19; Rom 16:5, 10-11, 14-16). Moreover, in the book of Acts, some passages provide the evidence that early Christ followers met in a private house in both Jerusalem and the territory of the Pauline missions (Acts $1: 13 ; 2: 46 ; 5: 42 ; 17: 5 ; 20: 7-12,20 ; 21: 16 ; 28: 30$ ): Based upon this assumption, the meal ritual in the Corinthian community is modelled after the triclinium and atrium of a Corinthian villa. ${ }^{403}$ This model, however, was called into question by David G. Horrell, who offers another scenario for the Corinthian community's assembly, based on the excavations of east of the theatre in Corinth. He argues that Corinthians were likely to gather in an upper room of such a commercial space, drawing on meal reports in the New Testament (Mark 14:15; Luke 22:12; Acts 1:13; 9:37, 39; 20:8-9). ${ }^{404}$ Finally, there is additional evidence pointing to several other spaces used by the early Christ followers. ${ }^{405}$ These proposals of possible spaces used for worship in nascent Christ movement point to the fact that there is no exclusive use of one kind of space over the other: Paul reminds the Corinthians that they themselves are the temple of the Holy Spirit (1 Cor 6:15-20).

\footnotetext{
${ }^{402}$ Vojtech Kase, "Meal Practices," in The Oxford Handbook of Early Christian Ritual, ed. Risto Uro et al. (Oxford: Oxford University Press, 2019), 417.

${ }^{403}$ Jerome Murphy-O'Connor, "Eucharistic and Community."

${ }^{404}$ David G. Horrell, "Domestic Space and Christian Meetings at Corinth: Imagining New Contexts and the Buildings East of the Theatre," NTS 50, no. 3 (2004): 349-69.

${ }^{405}$ Edward Adams, The Earliest Christian Meeting Places: Almost Exclusively Houses? (London: Bloomsbury, 2013), especially chapters 6-8.
} 


\subsubsection{Ritual times}

There is ample evidence both from the New Testament and other early Christian sources that, beginning in the middle of the first century, there was a fixed time for early Christ followers to assemble to celebrate the Lord's Supper. First, Paul asks the Corinthians to put aside funds at home on the first day of the week for the poor in Jerusalem (1 Cor 16:2). Paul singles out this date because it was already important for his Corinthian addressees, a day in which they gathered for table-fellowship. Next, Luke explicitly mentions Christ followers as gathering on the first day of week (Acts 20:7). ${ }^{406}$ Towards the end of the first century, the author of

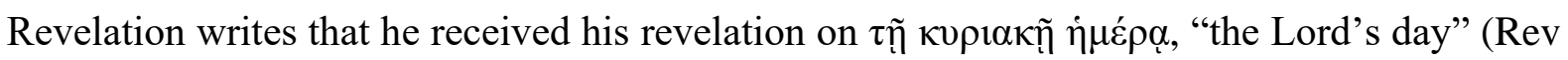
1:10). It has been suggested that this refers to Sunday. ${ }^{407}$ Outside of the New Testament, other early Christian literature attests that Christ followers usually gathered on Sunday - or the Lord's day - to celebrate the Lord's Supper (Ign., Magn. 9.1; Barn. 15.9; Did. 14.1; Gos. Peter 35; 50; Just., 1 Apol. 67.). Thus, based on the evidence, we should assume that the Corinthian community gathered on Sunday.

Besides the chronological time at which the Lord's Supper is celebrated, time is regarded differently in the ritual performance. According to Rappaport, what is represented in the liturgy is beyond temporal constraints; the acts that recover the eternal are intrinsically true and moral, providing grounds for evaluating history. 408 The cultic myths of Passover experience and the institution narrative are represented in the Lord's Supper meal; these are unique events that "are unconstrained by whatever culturally constructed 'natural laws" 409 are taken to prevail thereafter." We return to the ahistorical aspect of the Lord's Supper in section 3.5.3 below.

406 The phrase $\tau \tilde{\eta}$ غ̇ंav́pıov in this passage has been interpreted by some as Saturday. However, Valeriy A. Alikin (Earliest History, 41) has this to say: 'For if $\tau \tilde{\eta} \tilde{\varepsilon} \pi \alpha$ forov is taken in the strict sense of 'the next morning,' no new day needs to have begun when Paul left Troas. In that case Luke could have regarded the evening of the meeting at Troas as belonging to the next day and designated that evening as 'the first day of the week."'

${ }^{407}$ S. R. Llewelyn, "The Use of Sunday for Meetings of Believers in the New Testament," NovT 43, no. 3 (2001): 220-22.

${ }^{408}$ See Rappaport, Ritual and Religion, 233-34, which is contra Stanley K. Stowers, who thinks that "there is no myth without context, but only instances of particular individuals interpreting stories for particular purposes in specific settings" in "Kinds of Myth, Meals, and Powers: Paul and the Corinthians" in Redescribing Paul and the Corinthians, ed. Ron Cameron and Merrill P. Miller, ECIL 5 (Atlanta: SBL, 2011), 136n80. At one level, Stowers is correct that myth as a literary genre has its historical particularities, but when the myth functions within a ritual performance, it takes on the quality of eternity, for through the enactment of ritual performance the content of the myth is represented in its timeless realm.

${ }^{409}$ Rappaport, Ritual and Religion, 233. 


\subsubsection{Ritual objects}

The two basic objects used for the meal ritual are food and drink, which raises the question of the kind of food and drink served at the eucharistic banquet in first-century Corinth. There are two factors to consider: the range of food and drink consumed at the communal meal reflects that of Greco-Roman symposium, and ancient Corinth was a large metropolitan city with two harbours serving trade throughout the Mediterranean Sea. Given these two factors, it is reasonable to surmise that the communal meal in the Corinthian community would include bread, wine, cheese, oil, fish, and meat.

The use of bread and wine is widely attested in the earliest writings of the New Testament, Paul's letters (1 Cor 10:1; 11:26-28). There are writings outside the canonical New Testament from the second and third centuries confirming the use of wine in the communal meal (Did 9.2; Ire, Adv. Haer. 5.33.3; 5.1.3; 1.13.2). There is an exception to the bread-wine pattern; certain groups of Christ believers employed a bread-and-water tradition (Clem. $\mathrm{Al}$. Paed. 2.32.1-33.1; Str 1.96; Cypr., Ep. 63.1.16). ${ }^{410}$ The use of cheese and oil at the communal meal is attested by the Apostolic Tradition; those are consumed following the consecration of a bishop (Trad. Ap. 6). The consumption of oil at the meal table is further attested by Acts of Thomas and Clement of Alexandria (Acta. Thom. 29; Clem. Al. Ex. Theod. 82.1). The evidence for consumption of fish at the communal meal can be gathered from the feeding stories in the gospels and the stories of the risen Jesus eating fish with his disciples on Sunday (Luke 24:42; John 21:9-13; cf. John 6:11). The ubiquitous depiction of the fish symbol in nascent Christian mosaics, frescoes, and sculptures corroborates the Gospel accounts that fish could be served at group meals. ${ }^{411}$ Finally, although there are scant evidence and a tendency to avoid meat sacrificed to idols (1 Cor 8:1-13), there is reason to believe that meat would be served at the group suppers in Corinth. Paul writes on two occasions that things (meat) sacrificed to idols should not be deemed as defiled but as clean since idols do not wield power over those who would eat the meat (1 Cor 8:1-13; Rom 14:13-21). Moreover, the more affluent members in the Corinthian community would naturally serve meat, which might be an occasion for scandal amongst certain weak residents, whose conscience would not allow them to eat meat sacrificed to the idols. In short, based on the literary sources of early Christian writings and the wider Greco-Roman banquet context, these items are likely to have been served at the table of the Lord's Supper. The reason for discussing the food served at the communal meal in such detail

\footnotetext{
${ }^{410}$ See Andrew B. McGowan, Ascetic Eucharists: Food and Drink in Early Christian Ritual Meals (Oxford: Clarendon Press, 1999), 143-217.

${ }^{411}$ Alikin, Earliest History, 60n, 218, 219.
} 
is to show that, at least in the nascent Christ religion, the Lord's Supper was a proper meal, not simply a ceremonial occasion with the bite-size bread and sips of drink that are served in the later development of the eucharistic liturgy. This is precisely the catalyst for abuses at the Lord's Supper in the Corinthian community, for which Paul admonishes them to demonstrate a self-sacrificing spirit in the fair distribution of food at the Lord's table (see 3.5.1 and 3.5.2).

\subsubsection{Ritual languages}

Although the New Testament does not contain a complete ritual script for the celebration of the Lord's Supper, we can still detect some registers of ritual languages accompanying the rite. First, there is the cultic narrative accompanying the meal ritual; that is, the institution narrative to which Paul appeals (1 Cor 11:23-25; cf. Matt 26:26-29; Mark 14:22-25; Luke 22:15-20).

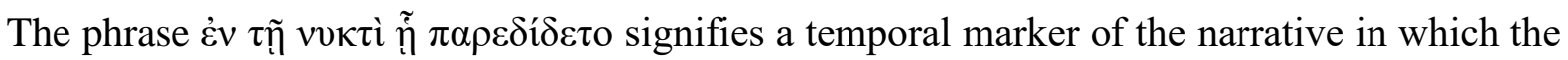
participants are taken back to the original scene of the founding event of the Christ religion. Similarly, the mystery cults in Greco-Roman world had a cultic narrative underlying the foundation of the ritual, such as the Eleusinian mysteries and their legomena, "things recited," in the first stage of ritual performance: a recounting of the foundational myth of Demeter. The eucharistic narrative to which Paul appeals includes not only Christ's death and resurrection (cf. 1 Cor 15:3-5) but also Paul's Midrashic reading of the Passover narrative in light of communal meal practices (1 Cor 10:1-5, 14-22.). Second, there is an ejaculatory prayer in the form of invoking God's name and maranatha. The calling of God's name in worship harkens back to the long-established tradition in the Old Testament, where the formula appears in cultic contexts (Gen 12:8; 13:4; 21:33; Ex 33:19; 34:5; Isa 12:4; Ps 105:1-5). ${ }^{412}$ The liturgical cry of maranatha reflects Paul's eschatological emphasis regarding the Lord's Supper tradition, that the communal meal anticipates the messianic banquet. Third, there is the reading of Paul's letters when the Corinthians gathered for worship, as indicated by the "liturgical inclusio" formed by 1 Cor 1:1-3 and 16:19-24. ${ }^{413}$ Finally, there is charismatic glossolalia once they are assembled, a development that requires an interpreter (1 Cor 14:6-12).

\subsubsection{Ritual groups}

In his statement in 1 Cor 12:13, Paul insinuates that the social composition of the Corinthian community is diverse. On the racial front, the Corinthian congregation consists of both Jews

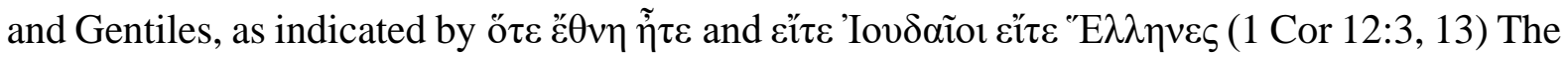

412 Pfitzner, "Proclaiming the Name," 17-18.

${ }^{413}$ Ibid., 16. 


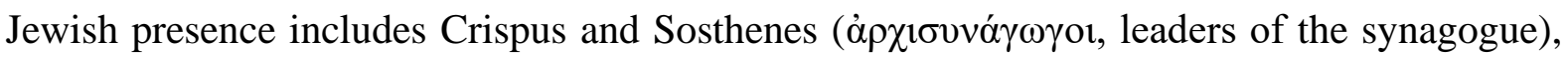
Aquila, and Apollos. ${ }^{414}$ On the social front, the data from the letter indicates that the community includes a many strata of society, from the wealthy to the poor. Earlier scholarship tends to agree with Clesus that the early Christ movement was a proletarian movement. ${ }^{415}$ However, recent scholarship has challenged this view, granting a higher social status than Deissmann had supposed. ${ }^{416}$ Thus, some scholars focus on the wealthy minority who wield influence over the congregation. ${ }^{417}$ Nevertheless, any study on the social composition of the Corinthian congregation needs to take into account social levels at both ends of the spectrum to give the fullest possible picture of the social situation in the early Christ movement. The

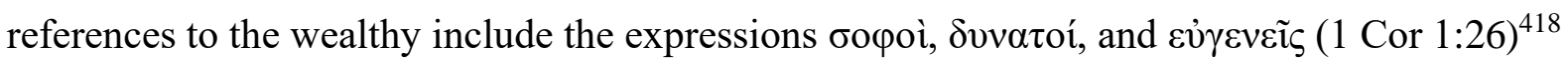
and the material means to provide for a lavish meal (1 Cor 11:17-24; cf. 1 Cor 4:8-13).

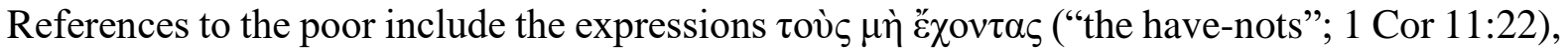
$\tau \grave{\alpha} \mu \omega \rho \hat{\alpha}$, $\tau \grave{\alpha} \dot{\alpha} \sigma \theta \varepsilon v \tilde{\eta}$, and $\tau \grave{\alpha} \dot{\alpha} \gamma \varepsilon v \tilde{\eta}$ (1 Cor 1:26) and the mentioning of slaves or dependent workers (1 Cor 7:21-24). ${ }^{419}$

The reconstruction of the ritual of the Lord's Supper form provides us with a full ritual apparatus that lays the groundwork to analyse the ritual function below. To illustrate, the ritual actions and actors relate to the role of the special agent(s) in the ritual performance (agency), the ritual times and places to the sphere in which the ritual is performed (virtuality), the ritual objects and languages to the ritual terms and structure of the performance (entailment), and the ritual group to the status of the participants during the performance (emergence and relationality). Before proceeding to the discussion of functions of the Lord's Supper, the study now turns to the social and cultural contexts of the ritual to better understand how the meal ritual in the Christ religion functions as both a meal and a sacrifice.

\subsection{Ritual Context}

Since in the next section the discussion employs the sacrificial understanding of the Lord's Supper and argues that it achieves communion between God and the participants, we first examine the wider context in which the meal ritual is related to the notion of sacrifice and

\footnotetext{
${ }^{414}$ Horrell, Social Ethos, 91-92.

415 Ibid., 92-93.

416 A. Deissmann, Light from the Ancient East: The New Testament Illustrated by Recently Discovered Texts of the Graeco-Roman World (Hodder \& Stoughton: London, 1927), 143-45, 250-51, 385.

${ }^{417}$ See Theissen, Social Setting, 69-120, and Meeks, First Urban Christians, 63-73.

418 Philo, Somn. 115: “Are not private citizens continually becoming officials ... obscure people

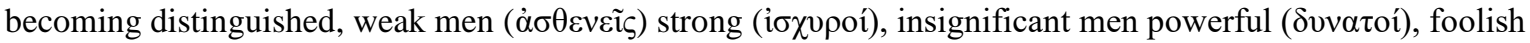
men wise men of understanding ( $\sigma v v \varepsilon \tau o i ́)$, witless men sound reasoners?"

${ }^{419}$ Horrell, Social Ethos, 98-100.
} 
fellowship with God. Socially, we investigate how the sacrificial understanding of the meal ritual on the part of early Christ followers differs from that of its pagan counterpart(s). This dovetails with the discussion on the historical emergence of the Lord's Supper. In other words, the efficacy of the ritual, which is reflected in its emergence, hinges on its impact on the wider social order: its values, worldviews, and political system. Culturally, despite the external differences in the meal ritual amongst Greco-Roman, Jewish, and Christ religion traditions, there is a common motif that underlies them all: fellowship between gods and participants. The meal culture in which the Christ religion was immersed informs our understanding of the Lord's Supper as an occasion for fellowship with both divine and human beings.

\subsubsection{Social context}

The Lord's Supper practiced by the early Christ movement belongs to the wider ritual system of sacrificial rites (slaughtered and meal sacrifices) in the ancient Mediterranean world. Both Greeks and Jews practiced their own sacrificial rites, with the former conducting sacrifices in a temple or domestic setting and the latter conducting annual sacrifices in the temple in Jerusalem before its destruction in AD 70. Given the sacrificial culture in which the Christ movement emerged, the Lord's Supper ritual was bound to adopt certain sacrificial connotations into its understanding. The common ritual symbol that underlies all these ritual groups is the sacrificial meal. However, despite that commonality, the ritual systems into which the Lord's Supper was incorporated clash with one another, creating a markedly different understanding of the sacrificial meal. ${ }^{420}$ We propose that this clash underlies the social aspect of the eucharistic ritual in the Corinthian community vis-à-vis its pagan environment when Paul addresses the issue of food sacrificed to idols (1 Cor 8-11). ${ }^{421}$ To facilitate our understanding that the Greco-Roman ritual system's conflict with that of the Christ movement is exemplified by the meal ritual in the two traditions, we examine four ways in which those traditions differ from each other: origins, meal table, sacrifice, and images of gods.

Commenting on the provenance of Greek and Roman sacrificial rites, Hans-Josef Klauck offers the following observation:

${ }^{420}$ Contra Pheme Perkins, First Corinthians, Paideia (Grand Rapids, Michigan: Baker Academic, a Division of Baker Publishing Group, 2012), 105: "Therefore the questions to which Paul responds do not appear to represent a head-to-head clash of ideological positions."

${ }^{421}$ See Bell, Ritual Perspectives and Dimensions, 173-77. 
The general answer has to be: everything is based on the vouó $\zeta$, i.e., inherited customs and usages, an unwritten law. The correct sequence of the ritual is mediated societally and derives from the tradition that has been handed down through the generations. ${ }^{422}$

Of all such customs, the Homeric epics provide a basis for the sacrificial rite. In $I l$. 1.458-68 the occasion for sacrifice was the ransoming of the daughter of Apollo's priest, Chryses, who asks Apollo to remove the curse from the Greek army that has taken his daughter into captivity. In $O d .3 .445-63$, the sacrifice of a cow that Nestor offers to the goddess Athena is accompanied by ritual shouting on the part of the women who are present, while in Od. 14.413-38, the sacrifice takes place in a domestic sphere where the sacrificial meal is held. Similarly, Paul makes it clear that the Lord's Supper ritual derives from Jesus himself, the originator of the rite: "For I received from the Lord what I also handed on ( $\pi \alpha \rho \varepsilon \dot{\lambda} \alpha \beta \sigma v)$ to you." The word $\pi \alpha \rho \varepsilon \dot{z} \alpha \beta \mathrm{ov}^{423}$ is a technical term Paul employs to signify that the Lord's Supper ritual originated with Jesus, the founder of the Christ religion, and the basis upon which the meal ritual is founded. The differences between the vó $\mu$ o $\varsigma$ of Greco-Roman sacrifices and the $\pi \alpha \rho \varepsilon \dot{\lambda} \alpha \beta$ ov of the Lord's Supper lies in their source: the former is of pagan origin, and the latter is rooted in the traditional language of the Old Testament.

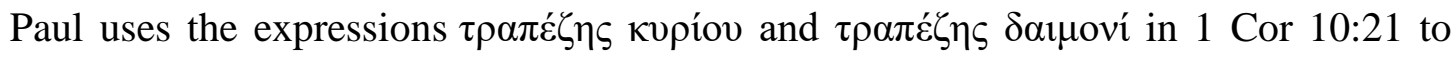
signify two different ritual systems in which Christ followers and their pagan counterparts operate regarding temple worship. Klauck sketches the basic form of a classical temple that contains $\tau \rho \alpha ́ \pi \tilde{\varepsilon} \zeta \alpha$ :

[I]n the middle of an oblong quadrilateral, with steps leading up to it, lies a closed room, the cella, into which light falls through an opening in the ceiling or through a high door giving on to the east. ... There are scarcely any other articles of inventory in this central part of the temple, apart from the $\tau \rho \alpha ́ \pi \varepsilon \tilde{\varepsilon} \zeta \alpha$ for the gods' meal, a small incense altar and some votive gifts.

It sufficed to sprinkle the altar with blood, to cast sacred barley into the fire and to burn the god's portion in the fire. ${ }^{424}$

Such is the temple and altar that Paul may well have in mind when he mentions that some "strong" ones in the Corinthian community partook of meat at the precinct of the temple (1 Cor 8:10) and employs the term $\tau \rho \alpha \pi \varepsilon ́ \zeta \eta \varsigma \delta \alpha \mu o v i ́$. By contrast, the true temple, according to Paul,

${ }^{422}$ Hans-Josef Klauck, The Religious Context of Early Christianity: A Guide to Graeco-Roman Religions, trans. Brian McNeil (Edinburgh: T\&T Clark, 2000), 17-18.

${ }^{423}$ The term is used in a technical sense elsewhere in Paul's writings: 1 Cor 11:2; 11:23a; 15:3; 1 Thess $2: 13 ; 4: 1$; Gal 1:9, 12; Phil 4:9. The term corresponds to the Greek tradition of cultivation in mystery religions ( $\pi \alpha \rho \alpha \delta i ́ \delta \mu 1$ : Plat., Phileb. 16c; Ep. 12.359d ( $\mu \tilde{\theta} \theta$ ov); Diod. S., Bibl. Hist. $12.13 .2 \pi \alpha \rho \alpha \lambda \alpha \mu \beta \alpha ́ v \omega:$ Plut., Is. et Os. 352c) and the Jewish tradition of handing over tradition (Wis 14. 15; Jos., Ap. 1.60). See Jeremias, Eucharistic Words, 101-5; Winninge, "The Lord's Supper," 597; Collins, The First Corinthians, 431; and Conzelmann, 19596.

${ }^{424}$ Klauck, Early Christianity, 23, 24. 
is not made of human hands but of the individuals that make up Christ's body (1 Cor 3:16-17; 6:15-19; cf. 2 Cor 6:14-18). Several observations emerge from this comparison:

1. The temple in which pagans worship is filled with idols that do not really exist in the world, whereas the temple that Christ followers dedicate has but one God.

2. The pagan temple is made of stones and wood, whereas the temple of the Christ cult is made up of individuals that are members of Christ's body.

3. The temple and its sacrifices of the pagans are impure since they are offered to demons, whereas the Christ cult temple is pure and holy because of the indwelling of the Spirit.

4. Animal blood is used at the altar in the pagan temple, as opposed to the blood of

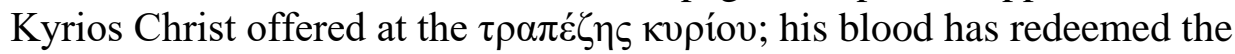
Corinthians.

The sacrifices offered at the altar of Greco-Roman temple are selected animals, whereas

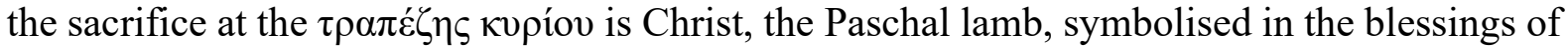
bread and wine. Paul himself identifies the communal meal with Christ the Paschal lamb in 1 Cor 5:5-8. In the Greco-Roman practices, the sacrifices include domestic animals: bulls, cows, pigs, goats, and sheep. ${ }^{425}$ The animals selected must be unblemished, and they are bedecked with ribbons and garlands in an honorary procession to the place of sacrifice. ${ }^{426}$ In the latter,

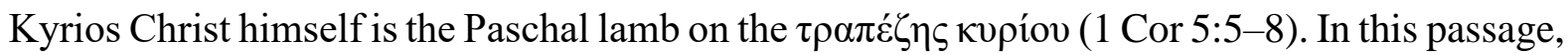
Paul uses Passover imagery ( $\pi \alpha \dot{\sigma} \chi \alpha, \theta v ́ \omega, \alpha ̋ \zeta v \mu o \imath)$ to signify the action of preparing and sacrificing the Paschal lamb. ${ }^{427}$ While some may argue that this passage should not be read together with the eucharistic ritual in 1 Cor 10 and the institution narrative in 1 Cor 11, one can also make the case otherwise. We demonstrate in detail why a synchronistic reading of these passages is possible in the next section, but for now we have already shown the inextricable link between the eucharistic ritual and the cultic narrative in section 3.2 Ritual Text. Unlike the pagan counterpart whose preparation of the sacrifice consists of selected animal stocks, the Christ followers are instead told to purge the yeast amongst themselves; namely, their moral defects. Although Paul does not say Christ the Paschal lamb is unblemished, it is logically

\footnotetext{
425 Ibid., 16.

426 Ibid., 16.

427 There is very little correspondence of the Paschal language to the instructions concerning Passover (Exod 12:10, 13; Lev 23:5-8; Num 9:1-14; Deut 16:1-8). See Victor Paul Furnish, "Belonging to Christ: A Paradigm for Ethics in First Corinthians," Interpretation 44, no. 2 (1990): 148, and Jane Lancaster Patterson, Keeping the Feast: Metaphors of Sacrifice in 1 Corinthians and Philippians (Atlanta: SBL Press, 2015), 131.
} 
implied by the imagery itself, as the Passover lamb must be spotless and unblemished (Heb 6). Anthony C. Thiselton delineates the effects of sacrificing the Paschal lamb:

Just as the Passover festival embraces a series of aspects and events, so the whole work of Christ, including his death and resurrection, includes many aspects. But the death of Christ corresponds to the death of the Passover lamb. Here, for Paul, the old is abolished and the blood of the Passover lamb ratifies the promises of redemption from bondage to a new purity and freedom by a costly act. ${ }^{428}$

The sacrifice of Christ the Paschal lamb releases the Corinthians from their bondage to the gods of this world and leads them to the "Sacred World of Unity": one God, one Lord, and body of Christ. $^{429}$

Finally, the attitude towards idols or graven images in the temple is markedly different in the pagan and Christ religion traditions. The interior of a pagan temple was thought to be a dwelling for the divinity, who was represented by cultic images in the form of wooden figures ( $\left.\xi_{o} \alpha v \alpha\right)$ or statues $(\dot{\alpha} \gamma \alpha \dot{\alpha} \lambda \mu \alpha \tau \alpha) .{ }^{430}$ The gods are were portrayed in human form, with source material drawn from early poetry and the plastic arts. ${ }^{431}$ The reason for human beings pining for images of God, according to Pheidias, is that humans are like small children who desire to stretch out their hands to their parents when they are separated. ${ }^{432}$ In 1 Cor 8:4-6 Paul, citing a well-known monotheistic slogan used by Hellenistic Judaism against Greek polytheism, concurs with the "strong" one in Corinth that idols have no reality in the world (1 Cor 8:4; Gal 4:8; cf. Isa. 44:9-20). ${ }^{433}$ However, he does acknowledge in v. 5 that there are entities which claim to be gods or lords and are worshiped by people in Corinth; however, for Paul and his audience, there is only one God, the originator of creation, and one Lord Jesus Christ, the agent of God in creation. ${ }^{434}$ Although Paul does not explicitly address the issue of graven images in

${ }^{428}$ Anthony C. Thiselton, The First Epistle to the Corinthians: A Commentary on the Greek Text. New International Greek Testament Commentary (Grand Rapids, Mich. : Carlisle: Eerdmans ; Paternoster Press, 2000), 405-6, emphasis original.

${ }^{429}$ Meeks, First Urban Christians, 160.

${ }^{430}$ Klauck, Early Christianity, 26.

${ }^{431}$ Ibid., 26.

432 Ibid., 27.

${ }^{433}$ Perkins, First Corinthians, 114; Conzelmann, 1 Corinthians, 142.

${ }^{434}$ Larry Hurtado sees in this passage an expression of the early Christian mutation of the Jewish monotheistic tradition; One God, One Lord: Early Christian Devotion and Ancient Jewish Monotheism (Philadelphia: Fortress, 1988), 97-99. 
relation to God in this passage, examining the rest of 1 Corinthians and his other letters reveals the following syllogism of his view on temple and images:

1. The Corinthians are members of Christ's body, which is the temple of God indwelled by the Spirit.

2. Men are created in the image of God and share his glory, which is Christ's image (1 Cor 10:7, 14; cf. 2 Cor 4:4; Phil 2:6; Rom 3:23; Col 1:15; Heb 1:3).

3. Therefore, the Corinthians represent the true icon of God.

Contra certain pagan view of gods and cultic images (which is also criticised by Hellenistic philosophers on the vanity of idol worship), ${ }^{435}$ the Christ religion views human beings as the true icon of God, who is one.

\subsubsection{Cultural context}

In 1 Cor 10 Paul speaks against sexual relations with prostitutes, which would undermine the table fellowship of the Lord (v. 16) and participating in meals associated with the gods since it constitutes a fellowship with demons (vv. 19-22). The theme of fellowship with gods in meals is a common motif underlying Greco-Roman, Jewish, and Christ religion meal rituals. In this section, we examine the meal ritual in the first two traditions, which evince the notion of fellowship with gods.

The argument that the gods associated with the cult meals in Greco-Roman tradition is thought to be participants in the banquet is not without objection. ${ }^{436}$ For instance, in his commentary on First Corinthians, Perkins challenges the notion that the gods are participants in these meal rituals:

Fellowship with the deity or human hero or emperor does not follow from making a sacrifice. Only a small group of individuals witnessed the animal's death. The feasting that follows at public festivals such as the Isthmian Games involves both persons and food distinct from the events at the altar. Furthermore, studies of Roman triumphs challenge the impression gained from literary sources that the populace at large participated in the banqueting. It would appear that only the elite were invited. ${ }^{437}$

${ }^{435}$ See van Kooten, "Pagan and Jewish Monotheism," 633-649.

436 There are three modes of presence that a deity may take in cultic meals: 1). The deity is a host; see Lanuwabang Jamir, "Exclusion and Judgment in Fellowship Meals: The Sociohistorical Background of 1 Corinthians 11.17-34," Ph.D. diss., Middlesex University, Supervised at London School of Theology, 2012; 2). The deity is a guest; see Dennis E. Smith, From Symposium to Eucharist: The Banquet in the Early Christian World (Minneapolis: Fortress Press, 2003), 176, 179, and Bell, Ritual Perspectives and Dimensions, 112; 3). The deity is in the food; see C. W. Bynum, The Resurrection of the Body in Western Christianity, 200-1336 (New York: Columbia University Press, 1995), 39.

${ }^{437}$ Perkins, First Corinthians, 105. 
In responding to Perkins's objection, we focus on two aspects: the connection between meal and sacrifice and the number of the participants.

On the issue of how meal relates to sacrifice, we have two lines of evidence supporting the argument that meal is related to sacrifice. First, Homer's Iliad served as a foundational story for meal rituals in Greco-Roman practice; it contains a description of a sacrificial banquet: "But when the thig-pieces were wholly burned and they had tasted of the inner parts, they cut up the rest and spitted it, and roasted it carefully, and drew all off the spits. Then, when they had ceased from their labor and had made ready the meal, they feasted, nor did their hearts lack aught of the equal feast." ${ }^{438}$ Here, we find sacrifice and meal held together in succession. Second, one of the terms denoting a sacrifice in antiquity is thysia, "in which a portion of the animal is burned at the altar and the rest is eaten." 439 This term is employed consistently with reference to the feast accompanying a sacrifice. For example, Plato considers both elements as part of the ritual in the following phrases: "When offering a sacrifice and feasting" and "sacrifices and feasts ... give honor to the gods." ${ }^{40}$ These pieces of evidence demonstrate that sacrifice and meal are deemed part of the sacrificial ritual, even though the sacrifice and festival that follows it are two distinct actions. ${ }^{441}$

On the issue of the number of participants in religious banquets, Perkins assumes that in order for a meal ritual to be conceived with the gods participating in it, both the elite and non-elite classes have to be present at the sacrifice. This assumption is without any basis, since the evidence we have from antiquity does not offer any hint that the participation of the gods is determined by the number of human participants. In fact, we have examples of both public and private forms of meal rituals that invite the fellowship of the gods. Amongst the former is Livy's recounting of lectisternia held in times of drought, plague, and military defeats, accompanied by meals held amongst the citizenry: "By means of a solemn meal for the gods which was then held throughout a period of eight days for the first time in the city ... it is said that the doors were open in the whole city ... that persons known and unknown, as they

\footnotetext{
${ }^{438}$ Quoted in Smith, From Symposium to Eucharist, 68.

${ }^{439}$ Smith, Symposium to Eucharist, 68.

${ }^{440}$ Plato Symp. 174C; Leg. 809D.
}

441 There are different kinds of meat consumed at the sanctuary, ranging from meat deriving from the sacrificial victims killed at the altar to the animals slaughtered in the sanctuary not in a thysia-manner. Nevertheless, these meats are deemed to have a sacred quality: "If we take meals consumed in sanctuaries to be sacred to some extent due to the setting, all meat eaten on those occasions could be regarded as sacred, although not all of it had had a sacrificial origin. An analogy can here be made with contemporary hallal or kosher butchering, which renders meat ritually proper and fit for consumption, though these rituals are not sacrifice" (Ekroth, "Sacred Meals," 1393). 
happened to come by, were invited as guests everywhere." 442 As to the private form, we have Lucius's celebration of a meal banquet following his final stage of initiation into the mysteries of Isis: "Then I celebrated the most festive birthday of the sacred rites and there were delightful feasts and elegant banquets (suaves epulae et faceta convivia)." ${ }^{\prime 43}$ Thus, the fellowship of the gods in meal banquets (theoxeny) constitutes an important element in Greco-Roman meal rituals.

In the Jewish tradition, one of the ways a meal ritual establishes a fellowship between God and humans is through memory. The main meal ritual in Jewish tradition is Pesach. The concept of memorial originates in the book of Exodus, in which the remembrance motif (זָכָר

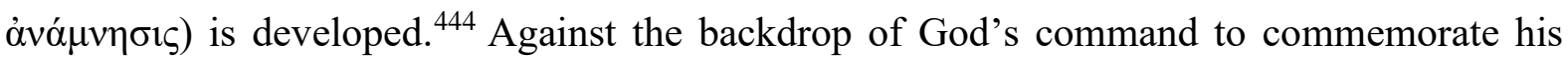
saving acts for the Israelites (Exod 2:23-25), Pesach is established as an annual festival. Regarding the link between fellowship and memory in meal rituals, Jeremias argues that the memorial formula "designates, always and without exception, a presentation before God intended to induce God to act." 445 In other words, the memorial formula does not merely recall the event to mind; it also affects a new event. Scholars call this effect the actualisation of a past event. ${ }^{446}$ Robert A. D. Clancy calls this into question, arguing that this would mean all of God's saving acts would be made present simply by being called mind (Deut 9:27; 24:9; 25:17). ${ }^{447}$ However, Clancy appears to ignore the context in which this actualisation takes place; namely, cultic ritual. It is within the cultic ritual, especially at the Pesach meal, that the past and the present are bridged. Consider the blessing over the cup in the Passover Haggadah:

Blessed art thou, O Lord, our God, King of the universe, who redeemed us and who redeemed our fathers from Egypt, and has brought to us this night, to eat thereon unleavened bread and bitter herbs. So, O Lord our God and God of our fathers, bring us to other festivals and holy days that come toward us in peace, happy in the building of thy city and joyous in thy service. And there may we eat of the sacrifices and paschal offerings, whose blood will come onto the walls of thy altar for acceptance. ${ }^{448}$

Note that, in the first part of the blessing, the prayer recalls the saving acts of God in the past; then comes the transition from the past event into the present through the use of conjunction

${ }^{442}$ Livy, Ab urbe cond. 5.13-18 (Foster).

443 Apuleius of Madauros, Metamorphoses.

444 There are seventeen occurrences of various forms of זָ in Exodus: 2:24; 3:15; 6:5; 12:14; 13:3, 9; 17:14; 20:8, 24; 23:13; 28:12 (x2), 29; 30:16; 39:7. See Susan I. Bubbers, A Scriptural Theology of Eucharistic Blessings (London: T\&T Clark, 2013), 157-66.

${ }^{445}$ See Jeremias, Eucharistic Words, 249; emphasis original.

${ }^{446}$ B. S. Childs, Memory and Tradition in Israel (Naperville, IL: Alec R. Allenson, 1961); P. A. H. De Boer, Gedenken und Gedächtnis in der Welt des Alten Testaments (Stuttgart: W. Kohlhammer Verlag, 1962); and W. Schottroff, Gedenken im Alten Orient und im Alten Testament (Neukirchen-Vluyn: Neukirchener Verlag, 1964).

${ }^{447}$ Robert A. D. Clancy, “The Old Testament Roots of Remembrance in the Lord's Supper," Concordia Journal 19, no. 1 (1993): 43.

${ }^{448}$ Quoted in Johnson, Religious Experience, 170n126. 
so, asking God to act on behalf of the participants to bring them to a divine banquet where they would enjoy everlasting bliss. The motif of eschatological banquet set on a mythological plain appears in both biblical and extra-biblical traditions. For example, Isa. 25:6-8 describes a messianic banquet against the setting of triumph over primordial enemies and judgement for all nations (cf. 1 Enoch 62.12-14). Moreover, 1QS28a 2:11-22 depicts a community meal over which the Priest-Messiah presides, and the participants gather to eat and drink new wine. Smith argues that such a messianic banquet was not in fact practiced in the Qumran community in that the meal ritual practiced there should not be identified as a sacred meal, citing Josephus's reference to the Essenes' meal practice. Silence at the table appears "to those outside ... like some awful mystery." ${ }^{449}$ However, when one reads 1QS28a 2:11-22 with 1QS 6.8-13, it is apparent that the cultic meal in the former agrees with the latter in terms of form and verbal identity. ${ }^{450}$ Thus, 1QS28a 2:11-22 gives a theological interpretation of the meal practice depicted in 1QS 6.8-13. This brief sketch of Jewish meal practice has shown that the meal ritual is not merely a recalling of past events but a link between past, present, and future in establishing a fellowship between God and the people.

The competing ritual systems of sacrifice amongst the Greco-Romans and the Christ believers, as analysed above, demonstrate that the efficacy of the Lord's Supper depends on the faithful's taking their places at the table of the Lord. In fact, as Paul argues, the sacrifice made at a pagan altar does not affect anything; pagan gods are non-existent, for there is only one God and one Lord, Jesus Christ. The common motif of fellowship with God in GrecoRoman and Jewish meals shows the historical precedent of the motif in the Lord's Supper. As such, Paul would have understood a ritual meal as an act in which the participants come into contact with the divine.

\subsection{Ritual Function}

We are now able to analyse the ritual function of the Lord's Supper using the performance theories, as we did in chapter 2 with baptism: agency, entailment, virtuality, emergence, and relationality. Each category contributes to the overall transformative experience of the participants in their communion with God in the ritual performance. To the performance model, we add another category: sacrifice. As the previous section has demonstrated, the Christ religion emerges from a sacrificial culture in which the imagery of sacrifice pervaded

\footnotetext{
${ }^{449}$ Josephus, J. W. 2.129, 133; Smith, Symposium to Eucharist, 67.

${ }^{450}$ Karl Georg Kuhn, "The Lord's Supper and the Communal Meal at Qumran," in The Scrolls and the New Testament, ed. Krister Stendahl (New York: Crossroad, 1992), 71.
} 
contemporary religious thinking. Inevitably, it links Christ's death with its central ritual performance, the Lord's Supper, which commemorates that death in terms of sacrifice. We already see this rhetoric of sacrifice is applied to the Lord's Supper by Paul in 1 Cor 11:23-26, wherein the vicarious interpretations are given for both bread and wine.

A few words on the rhetoric of sacrifice are in order. Having surveyed the major theories of sacrifice, James W. Watts notes that all modern interpreters have failed to distinguish between animal offerings and those based on human killing in dealing with traditional sources. ${ }^{451}$ This issue is elucidated by another distinction in sacrifice theories: the description of ritual sacrifices from ancient texts and stories, including myths, legends, and historiography in which sacrifice plays a prominent role. ${ }^{452}$ These dichotomies reflect not only different evaluations of the same evidence but also point to two different things: rituals involving foods, often animals, and the stories centred on killing humans. Watts thus concludes that "the correlation of stories with rituals under the category of sacrifice represents a secondorder interpretation that is not intrinsic to the rituals. Such correlations serve to evaluate a ritual on the basis of a story and do so for purposes of persuasion. Sacrifice then is best understood as a normative, rather than descriptive term." 453

This distinction between rituals involving food and stories revolving around the killing of humans can be detected in 1 Corinthian's references to the Lord's Supper, as shown in the chart below.

\begin{tabular}{|c|c|}
\hline Ritual & Stories \\
\hline $\begin{array}{c}\text { 1. 1 Cor 10:14-22: Allusion to the blessings } \\
\text { of the cup and bread at the Lord's Supper }\end{array}$ & $\begin{array}{c}\text { 1. 1 Cor 5:6-9; 10:1-5; 12:13: Paschal story } \\
\text { in which Christ is identified with the slain } \\
\text { lamb }\end{array}$ \\
\hline $\begin{array}{c}\text { 2. 1 Cor 9:13-14: Allusion to the temple } \\
\text { and sacrifice at the altar }\end{array}$ & $\begin{array}{c}\text { 2.1 Cor 11:23-26: Institution narrative in } \\
\text { which Christ is offered in the form of bread } \\
\text { and wine }\end{array}$ \\
\hline
\end{tabular}

The left column offers brief descriptions of sacrificial and meal rituals, whereas the right column presents the stories of Passover and Christ's final night, in which the notion of sacrifice is conspicuous. However, the distinction that Watts seeks to draw between sacrifice deriving from narrative and ritual eating from animal sacrifice breaks down in this case. As we have demonstrated in the section on ritual text, the communal meal is closely related to the cultic

${ }^{451}$ James W. Watts, "The Rhetoric of Sacrifice," in Ritual and Metaphor: Sacrifice in the Bible, ed. Christian A. Eberhart (Atlanta: SBL, 2011), 6-7.

${ }^{452}$ Watts, "The Rhetoric of Sacrifice," 7 .

${ }^{453}$ Ibid., 8; emphasis original. 
narratives by contextual evidence, performative indicators, and the relationship between ritual and myth in the founding of a community. Furthermore, the correlation of ritual involving food to animal sacrifice does not apply to the Lord's Supper since, although the ritual involves common food, bread and wine, it points to the human person of Kyrios Christ as the sacrifice. The application of the Paschal lamb metaphor to Christ is just that: a mere metaphor that does not insinuate that Christ is an actual lamb. The reason for this discussion regarding the rhetoric of sacrifice is that we need to bring both the ritual performance theories and the notion of sacrifice to bear on the analysis of the Lord's Supper; both are required to do justice to the function of the meal ritual.

\subsubsection{Agency}

Using E. Thomas Lawson and Robert N. McCauley's theory regarding agency in ritual performance, the Lord's Supper has a special agent. According to one of the principles of superhuman agency, "those rituals where superhuman agents function as the agent in the ritual will prove more central to a religious system than those where the superhuman agents serve some other role." 454 This principle captures the assumption of religious rituals that a ritual's efficacy depends on cooperation from superhuman agents. ${ }^{455}$ Applying this principle of superhuman agency to the Lord's Supper ritual, we see that it requires a special agent in celebrating the rite; that agent is Jesus, whom his followers regard as the founder of the cultic practice according to the institution narrative. In that narrative, Jesus is seen as the originator of the rite by introducing certain innovations to the Paschal meal: the blessings of bread and wine are connected to his body and blood, which will be shed for his disciples and the world. The importance of a special agent ritual is accentuated through the use of first-person pronouns

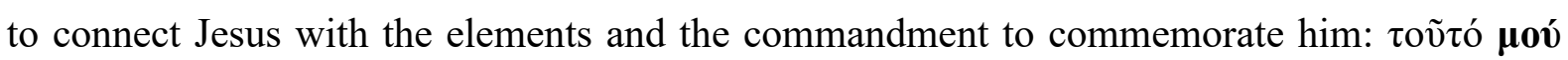

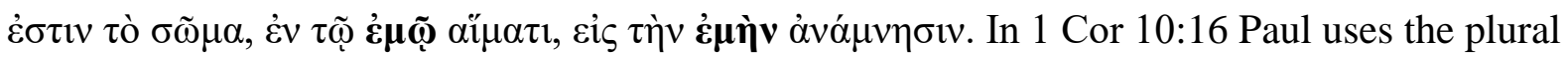
forms of the verbs $\varepsilon \dot{v} \lambda \sigma \gamma o \tilde{\nu} \mu \varepsilon v$ and $\kappa \lambda \tilde{\omega} \mu \varepsilon v$, which raises the question of who is responsible for the blessing. Kase suggests that Paul is referring to the paterfamilias of the house in which the Corinthian community has congregated. ${ }^{456}$ There are several reasons to support this claim. First, of all the ekklēsia offices Paul outlines in 1 Cor 12 (prophets, apostles, wonderworkers, etc.), none seems closely related to the liturgical function of celebrating the Lord's Supper. Second, as the discussion below shows, the activities of Christ followers were bestowed with a priestly

\footnotetext{
${ }^{454}$ Lawson and McCauley, Rethinking Religion, 125.

455 Ibid., 125.

456 Kase, "Meal Practices," 417.
} 
image in the earliest decades of the Christ movement. Third, the Christ association is thought to be a household unit, whether that is a local or a wider community. Fourth, the similarities between the role of a cult leader in the ceremony and that of the Christ religion has been noted by Christ followers, with some qualifications. ${ }^{457}$ Taking all these observations together, the most fitting description for the role of celebrating the Lord's Supper is paterfamilias. We provide evidence that paterfamilias is likely the special agent for the Lord's Supper ritual in the Corinthian community, the one who fulfils priestly functions towards the community in both religious and economic terms.

First, we need to look at the role the paterfamilias plays in domestic religious rituals in the Greco-Roman world. Cato the Elder, writing a treatise to a foreman about how to perform his duties when the master is absent, suggests that a paterfamilias presides over the religious ceremonies in the household: "The following are the duties of the overseer: He must show good management. The feast days must be observed." 458 The paterfamilias has a priestly duty to the household deity, or genius, the "procreative life-force" of the paterfamilias. ${ }^{459}$ As a spirit watching over the household and preserving the family nomen, the genius receives worship on the important life events of the paterfamilias, such as his birthday and the day of his marriage. ${ }^{460}$ Moreover, the paterfamilias is responsible for the acts of worship that take place at the daily meal, where a small portion of the food is allocated to the gods.

Despite the dissimilarities between the Lord's Supper and domestic Roman religious ritual, the role of paterfamilias in both religious settings is the same; namely, presiding over the religious ceremony or rite. First, the early Christ religion meets in a domestic setting for worship, even if the precise locations of their meetings varied. The domestic nature of the early Christ religion is attested by numerous references to the oĩ different communities (1 Cor 16:19; Phil 1:2; Rom 16:1-27; cf. Col 4:15) and Luke's account of Christ's early followers preaching activities that take place at home (oĩkov; Acts 2:42, 46;

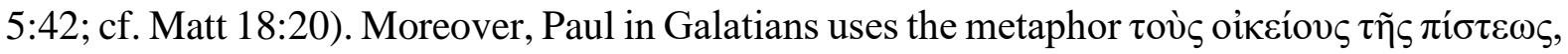
"the household of faith," to refer to the community, which indicates that the metaphor could

457 "You are all, therefore, also fellow cult members (sunodoi), God-bearers (theophoroi), and templebears (naophoroi), Christ bearers (christophoroi), bearers of holy things (haiophoroi), in every way adorned with the commandments of Jesus Christ"; Ignatius. Eph. 9.2., quoted in Allen Brent, Ignatius of Antioch: A Martyr Bishop and the Origin of Episcopacy (London: T\&T Clark, 2007), 73-94.

${ }^{458}$ Cato, Agr. 5.1.

${ }^{459}$ Celia E. Schulz, Women's Religious Activity in the Roman Republic (Chapel Hill: University of North Carolina Press, 2006), 124.

460 David G. Orr, "Roman Domestic Religion: The Evidence of the Household Shrines," in ANRW 2.16.2: 1570 (1978). 
have derived from the place of worship in the earliest time of Christ religion, which, in turn, reinforces the domestic nature of nascent Christ associations (Eph 2:19-22; 1 Pet 2:4-5). ${ }^{461}$

Second, since sacrificial language was applied to the Christ community from the earliest decades of the Christ religion (e.g., Acts 10:4; Rom 12:1; 15:16; Phil 2:17;4:18) and was linked with the meal ritual, the role of the presider over the eucharistic ritual also takes on a priestly function. ${ }^{462}$ On several occasions, Paul explicitly links his actions and that of the communities with the sacrificial cult. In Phil 2:17, Paul states, "But even if I am being poured out as a libation

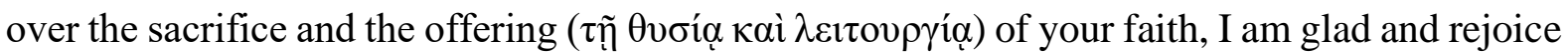
with all of you." In Rom 12:1 he urges his readers as follows: "I appeal to you therefore, brothers and sisters, by the mercies of God, to present your bodies as a living sacrifice ( $\theta v \sigma i ́ \alpha v$ $\zeta \tilde{\omega} \sigma \alpha v)$, holy and acceptable to God, which is your spiritual worship." Furthermore, in Rom 15:16, Paul links sacrifice and priest when speaking of his missionary activities amongst the

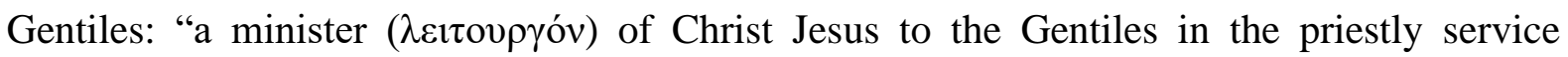

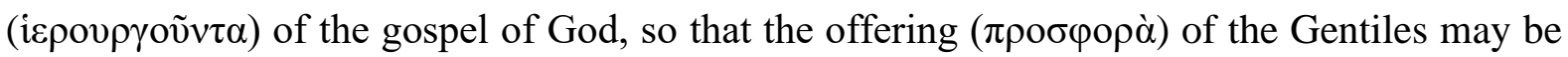
acceptable, sanctified by the Holy Spirit." Although these passages do not appear in the explicit context of the eucharistic ritual, their sacrificial images are to some extent shaped by the liturgical experience, especially the eucharistic ritual. This is clearly borne out by comparing them with the Lord's Supper references in 1 Cor 5:7 - "For our paschal lamb, Christ, has been

${ }^{461}$ Meeks and John S. Kloppenborg argue that the Lord's Supper has no contact with domestic practice.

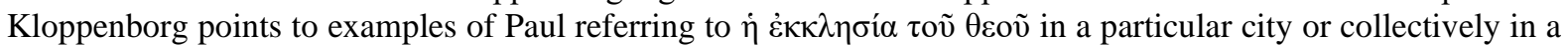
larger geographical area (Rom 16:1; 1 Cor $1: 2 ; 10: 32 ; 11: 22$; 2 Cor 1:1; 1 Thess $1: 1$; Rom 16:4, 6; 1 Cor 7:17; 11:16; 14:33; 16:1, 19; 2 Cor 8:1, 18; Gal 1:2, 22; 1 Thess 2:14; 2 Thess 1:1), which suggests that Paul conceives of the ekklēsia as larger than individual households. See John S. Kloppenborg, "Greco-Roman Thiasoi, the Ekklesia at Corinth, and Conflict Management," in Redescribing Paul and the Corinthians, ed. Ron Cameron and Merrill P. Miller, ECL 5 (Atlanta: SBL, 2011), 192. However, the terms for domestic or household in Greek, oĩ or oikía, and in Latin, domus and familia, have wider senses than the narrow use that refers to a residential building or nearest kin. It includes the larger family, including slaves, relatives, friends, and clients. This dual notion of family serves as a model for the social and economic structure of the classical world. Aristotle notes the structural similarity between oikos and polis, house and city-state. The latter functions like a large house, linking it to the heads of household, who have seats in the full assembly of citizens (Klauck, The Religious Context, 58). Likewise, when Paul speaks of the assembly of Christ followers in a large region, it could be the case that they gather from local house churches hosted by a benefactor. Meeks denies the domestic context of Christ religion rituals, noting that there was no contact with the domestic cult of a Roman or Greek house (First Urban Christians, 77). There is, however, an aspect of domestic cult that did have contact with the meal ritual of the Christ religion, which is the daily meal. Klauck describes the ritual performance: "A small portion of everything placed on the table belongs to the gods. Amongst the Greeks, the transition from the meal to the drinking feast involved a sequence of three ritual offerings, one of which was made to the Agathos Daimon, who stands for the good spirit of the house. ... Plutarch calls the table where guests are welcomed to a meal 'an altar of the gods of friendship and of hospitality"' (The Religious Context, 60-61). As we have already discussed, the meal ritual of the Christ religion is part of wider meal banquet practices in the Greco-Roman world that exhibit similar structures and motifs, in this case the blessings of the cup and the notion of fellowship with God at the meal.

462 Timothy Wardle, "Who is Sacrificing? Assessing the Early Christian Reticence to Transfer the Idea of the Priesthood to the Community," in Ritual and Metaphor: Sacrifice in the Bible, ed. Christian A. Eberhart (Atlanta: SBL, 2011), 103. 


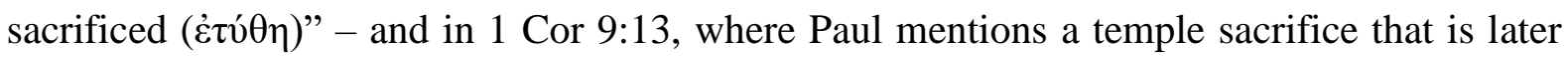
compared to the Lord's Supper in 1 Cor 10:14-22: "Do you not know that those who are

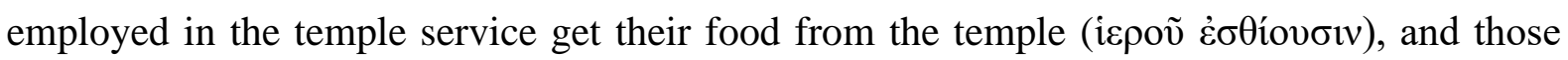

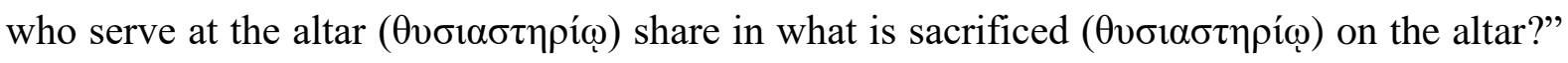
Given the application of sacrifice language to the activities of early Christ followers, including in the meal ritual, it is natural that the presider over the rite must be serving in some priestly capacity, as in the domestic Roman religion counterpart.

Thirdly, just as the paterfamilias in domestic Roman religious ritual is the head of the household, the paterfamilias in the Christ religion could well be the one who hosts the whole community when they assemble. The patriarch of the family provides both economic and religious support to his family. By the same token, the paterfamilias of the Christ religion hosts the agape meal for the whole community and takes the lead in spiritual duties. Although there is no direct evidence from 1 Corinthians to support this position, we can still consider Paul's account of the abuses that happened in the Corinthian community (11:17-34). It has been established that the form of the meal ritual celebrated in the community is comparable to that of Greco-Roman dinner party; there are two tables, and each commences with a blessing or invocation of the geniuses of the host or emperor. ${ }^{463}$ Given that the Corinthians' communal meal is a proper meal that requires someone of economic means to host the whole community and that some of the affluent members of the community begin the communal meal prematurely, the implication is that these elite members play a dominant role in celebrating the Lord's Supper; the host, especially, is likely the one who starts each table meal with blessings over the food. Not only does the paterfamilias of the Corinthian community have to provide food for the community; he also serves as an example in demonstrating the spiritual ethos of lovepatriarchism (1 Cor 7:21-24; 11:3-6): “This love-patriarchalism takes social differences for granted but ameliorates them through an obligation of respect and love, an obligation imposed upon those who are socially stronger." ${ }^{464}$ The host of the community, given his social and economic status, is expected to take the initiative to show this love ethos towards weaker members. Therefore, the paterfamilias is the one who acts as a host to the community and takes the lead in showing Christian love-patriarchalism.

463 Peter Lampe, "The Eucharist: Identifying with Christ on the Cross," Interpretation 48 (1994): 36-49; Peter Lampe, "The Corinthian Dinner Party: Exegesis of a Cultural Context (1 Cor. 11:17-34)," Affirmation 4/2 (1991): 1-15.

464 Theissen, Social Setting, 107. 


\title{
3.5.2 Entailments: Myth and sacred discourse
}

One of the structures that are entailed in the ritual performance is a myth. The relationship between myth and ritual can be defined in terms of the reciprocal relations of words and actions:

\begin{abstract}
Myth regarded as a statement in words does not, contrary to Leach, say the same thing as ritual regarded as a statement in action. Much of what is said in ritual is, of course, said in myth ... but ... there are things said by all liturgical rituals that cannot be said in other ways. They are in part expressed by the act of performing it. The act of performance is itself a part of the order performed, or, to put it a little differently, the manner of saying and doing is intrinsic to what is being said and done. ${ }^{465}$
\end{abstract}

Here, Rappaport argues that myth and ritual are two different entities that are nevertheless related to one another as words are to actions. The differences lie in the stipulated relationship between the ritual and the participants, which implies that referential information or a canonical message is conveyed to the participants and the indexical message of the acceptance of the content of the performance. Myth, on the other hand, carries no such messages in that the narrator of the myth and the audience have no necessary relationship; neither the narrator nor audience is required to accept the myth. ${ }^{466}$ Despite the clear distinction between myth and ritual, they sometimes do operate together. This can be illustrated in the case of the creation myth and its accompanying ritual performance. In the enactments of ritual performance, there is a reunion of two primitive categories, form and substance, which come apart after departure from the order. In ritual, there is a reestablishment of the form through invariant liturgical words (myth) whose content is substantiated by ritualised bodily postures (ritual); there are a representation and recreation of the primordial order, the union of form and substance. ${ }^{467}$

This study suggests that, in the performance of the Lord's Supper, there is just such a reunion of form and substance, a recreation of the primordial order. Granted, one might object that the cultic narrative accompanying the eucharistic ritual is not a creation myth and that the aforementioned theory is thus not applicable to the meal ritual. ${ }^{468}$ Although the cultic narrative is not a creation myth per se, it is nonetheless a creation myth in the sense that it speaks of the creation of a new community out of a chaotic society, just as the creation of the cosmos arose out of primordial chaos. The cultic narratives embedded in the eucharistic ritual include the

465 Rappaport, Ritual and Religion, 38.

466 Ibid., 134-35.

${ }^{467}$ Ibid., 164.

${ }^{468}$ Petra Dijkhuizen writes that, in antiquity, "sacrifices are perceived to guarantee the wholeness of the cosmos as they rectify disturbed life processes and disorder (cf. Gen 8:20-22; the Noahic covenant). In the GraecoRoman world too, sacrificial ritual was crucial to the establishment of cosmic order. Sacrifice arranged proper relations amongst human beings and between humanity and the gods. It emphasised differences between different classes of human beings as well as between human beings and animals"; see Petra Dijkhuizen, "The Lord's Supper and Ritual Theory: Interpreting 1 Corinthians 11:30 in Terms of Risk, Failure, and Efficacy," Neotestamentica 50, no. 2 (2016): 458. 
Passover saga of the Israelites and the formation of the Israelites as a nation under the covenant with Yahweh (Ex 12 || 1 Cor 5:7; 11:26; Ex 24 || 1 Cor 10:1-3; cf. Jer. 31:31; 38:31 LXX). These stories serve as a founding narrative for the nation of Israel, which is ritually retold at Passover annually. The nation of Israel came into existence through the salvific acts of Yahweh, who brought them out of Egypt, which symbolises the primordial chaos, indicated by the twelve plagues that target a specific deity that the Egyptians worship. Yahweh brough the Israelites into a unity under the stipulation of worship of him and him alone. Similarly, the meal ritual of the Christ religion, which is modelled on the Passover meal, enacts the creation of a new community under the auspices of Jesus, whom the early Christ followers deemed to be a new Moses. This new community comes into being through the ratification of a new covenant that Jesus introduced to his twelve disciples on his final night. Akin to the Israelites of old, Christ followers escape from the world of chaos defined by the worship of polytheism (1 Cor 8:4-6) and social and ethnic divisions. There is an acute awareness on the part of the Christ followers that they have left behind the present order to enter a new realm of existence

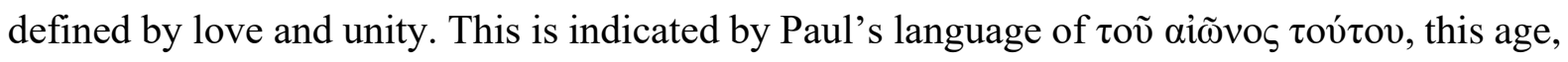
characterised by epistemological darkness (1 Cor 1:20; 2:8; 2 Cor 4:4; Gal 1:4; Rom 12:2), as opposed to the realm of the Kingdom of Christ (Col 1:13) marked by a new creation of humanity (2 Cor 5:17; Gal 5:6; 6:5).

In the meal ritual, there is a reunion of form and substance, a union of primordial order. The form of the ritual consists of words in the form of the myths that accompany it. We have already mentioned that there are two layers of cultic narratives embedded in the Lord's Supper: the Passover saga in light of the Christ event and the institution narrative. The form of the ritual is, then, substantiated by bodily postures that indicate the acceptance of its canonical message. The postures include the act of eating bread and drinking wine and the proper way to carry out the meal. Regarding the former, the act of eating and drinking points to the participation in a new social body, Christ's body, which consists of different members. Each individual realises his or her identity through participation in the meal ritual; they are all different members of Christ's body by partaking of the same bread and cup. Regarding the latter, Paul addresses the abuses that occur at the Lord's Supper, as some affluent members of the community prematurely begin the meal, leaving little food over for the poor in the community who come late. Such incommensurate food distribution causes divisions amongst the Corinthian community along both social and theological lines, ${ }^{469}$ which is contrary to the ritual form

${ }^{469}$ See Martial, Epigr. 3.60; Pliny the Younger, Ep. 2.6; Juvenal, Sat. 5.162. 
stipulated in the liturgical words that all are one in Christ. The meal ritual meant to be a recreation of order disintegrates into fractions when the participants do not act according to the stipulation of the ritual that all partake of one bread. Thus, Paul can say that, when the Corinthians assemble, it is no longer the Lord's Supper that they are eating (1 Cor 11:21).

This leads to our discussion of sacred discourse in the Lord's Supper ritual. The sacred discourse refers to the various expressions both in content and rhetorical form entailed in the ritual that stipulates a specific action or class of actions to be undertaken or eschewed. ${ }^{470} \mathrm{In}$ addition to the establishment of a convention, the ritual performance also establishes morality. In ritual language, morality means either the fulfilment or breach of the terms of the obligations encoded in that ritual. A breach of obligation is construed to be immoral since "it transforms otherwise morally positive, neutral or empty acts into crimes such as murder or robbery." ${ }^{471}$ Morality is not only inherent in the terms of obligations in ritual but also in the very structure of liturgical performance. Relating the inverse relationship between a statement and the state of affairs, Rappaport formulates the following relationship between the state of affairs and the performative act: "We judge the state of affairs by the degree to which it conforms to the stipulations of the performative act." ${ }^{\prime 42}$ In other words, morality ultimately derives from what the ritual establishes or the conventional order brought into being.

Turning to the eucharistic meal, we find morality is entailed in both its terms and its ritual structure. Since we have adopted a sacrificial reading of references to the Lord's Supper in 1 Corinthians, we see the moral obligations contained therein as follows: whether the Corinthians have fulfilled or breached the obligations encoded in the sacrificial meal. ${ }^{473}$

The statements on moral obligation derived from the meal ritual are indicated by a series of rhetorical questions posed by Paul:

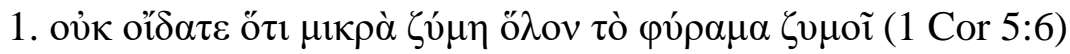

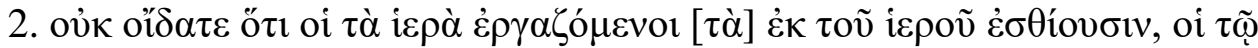

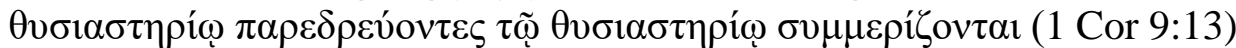

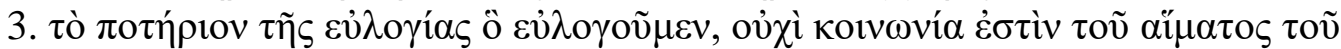

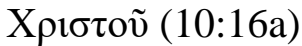

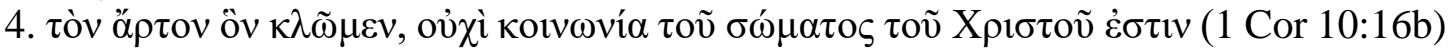

\footnotetext{
${ }^{470}$ Rappaport, Ritual and Religion, 317.

${ }^{471}$ Ibid., 132.

472 Ibid., 133.

${ }^{473}$ See Michael Lakey, The Ritual World of Paul the Apostle: Metaphysics, Community and Symbol in 1 Corinthians 10-11, LNTS 602 (London: T\&T Clark, 2019), 134.
} 


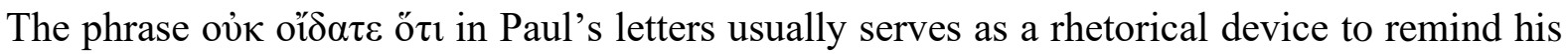
readers of the teachings in which they have been schooled. In this case, Paul is reminding them of the terms of obligation associated with the sacrificial meal. According to those terms, the Corinthians need to purify their community of men of immorality who have breached the obligation since, just as the celebration of the Passover meal requires unleavened bread, the Lord's Supper ritual stipulates "the unleavened bread of sincerity and truth." Failing to bring the unleavened bread of sincerity and truth to the table of the Lord results in the excommunication of the individual from the fellowship of the table (1 Cor 5:11) Another term of the stipulation that the Corinthians have violated is participation in the pagan sacrifice, which is a liturgical taboo. Alluding to the story of Israelites engaging in idol worship of the golden calf, Paul explicates that, since participation in the sacrificial meal offers the Corinthians

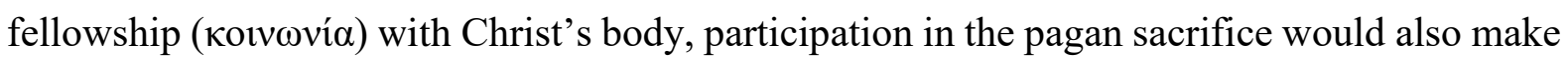
them partners of demons. One cannot have fellowship with both God and demons, for absolute and exclusive fidelity is demanded by both.

Next, the conventional order of the Lord's Supper establishes a morality of unity within the body of Christ. This conventional order includes the blessing of the bread, symbolising the body offered to God, as in the animal sacrifice in the Old Testament. The bread replaces the bloody sacrifice of animals and symbolises the body of Christ. ${ }^{474}$ This entails the fair allocation of food at the table for all participants and a self-sacrificing spirit for one another, both of which signify the unity of Christ's body. Based on Paul's address of the abuses at the Lord's Supper, the Corinthians' state of affairs has failed to conform to the performative acts of the meal ritual. The chiastic structure of 1 Cor 11:17-34 bears this out.

A 11.17-18a Assembled as an ekklēsia ( $\sigma v v \varepsilon ́ \rho \chi \varepsilon \sigma \theta \varepsilon)$
B $11.18 \mathrm{~b} \quad$ Divisions and fractions $\sigma \chi i ́ \sigma \mu \alpha \tau \alpha$

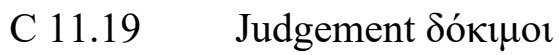
D 11.21-22 Breach of obligation
E 11.23-26 The Lord's Supper tradition
D' $11.27 \quad$ Breach of obligation

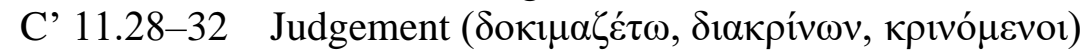

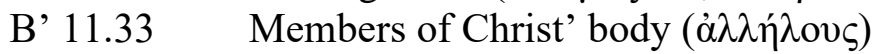

\footnotetext{
${ }^{474}$ Using the concepts of mimesis and replacement, which are crucial to any sacrificial acts, Dijkhuizen has demonstrated that at the eucharistic ritual there is a ritual killing of Christ, who is a victim of the sacrificial meal. "In the Lord's Supper too, Jesus's followers mimetically enact the essence of a crisis. Jesus's death is now the moment of crisis. They repeat the fatal event of the crucifixion of their martyr leader, Jesus. The breaking of his body is mimetically repeated by the members of the community through the breaking of the bread in the shared meal. ... Jesus's death as self-sacrifice also involves replacement. Jesus not only becomes the victim whose body is broken, he also acts as the scapegoat that is driven outside the camp. On Jesus was re-placed the burden of his fellow humans and he was relocated, driven 'outside the camp,' to be crucified as the 'Lamb of God' (Heb 13:13; John 1:29)," Dijkhuizen, “The Lord's Supper and Ritual Theory," 463, 465.
} 


\section{A’11.33-34 Assembled as an ekklēsia ( $\sigma u v \varepsilon ́ \rho \chi \varepsilon \sigma \theta \varepsilon)$}

The verb $\sigma v v \varepsilon ́ \rho \chi \varepsilon \sigma \theta \varepsilon$ in vv. 17, 18, 33, and 34 clearly indicates that the abuses Paul addresses are not simply a social issue but a violation of ritual terms. The divisions manifested in the unequal allocation of food contradict the conventional order of the Lord's Supper, which

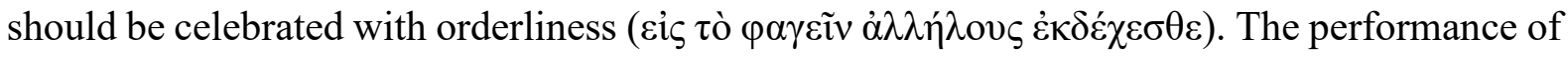
the Corinthians at the Lord's Supper is judged ${ }^{475}$ based on the following criteria: ${ }^{476}$

1. The examination of oneself for genuineness before God (11:28).

2. How one relates to other members of Christ's body (11:22).

3. Discerning the body (11:29).

Based upon these tests, the Corinthians have failed to conform to the performative acts of the Lord's Supper ritual through factions, the humiliation of the have-nots, and profaning the body and blood of the Lord. The very act of offering bread and wine in the eucharistic ritual establishes a fundamental ethos for Christ followers; the self-sacrificing love towards the members of the body that is encapsulated in the condensed form of the institution narrative (11:23-26).

\subsubsection{Transformation: Virtuality and historical emergence}

We now reach the crucial moment of this ritual performance; namely, the transformation process of the participants. Ritually speaking, there are two aspects of transformation taking place in the ritual performance. The first deals with the notion of ritual as a technological dynamic that creates a virtual space in human reality that constitutes a suspension of some of the flow of ongoing existence to manipulate and reconfigure human reality. This virtual space created by the ritual serves as "a kind of phantasmagoric space" in which the participant can start breaking from "the constraints or determinations of everyday life," enabling them to achieve reorientation, regeneration, and recreation. ${ }^{477}$ This virtuality is ahistorical since it does not "reduce the present to a particular point of origin at some moment in a lived past." 478 Rather, it produces myriad lived pasts and a diversity of futures. ${ }^{479}$ The second aspect deals with the concept of emergence: what ritual performance brings about in social reality. Writing on the processes of ritual performance, Schieffelin argues that the efficacy of a ritual performance

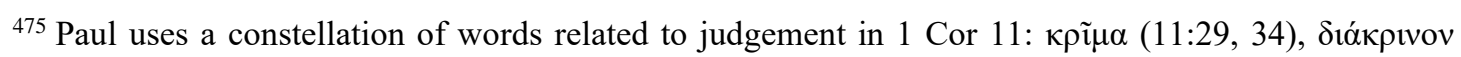

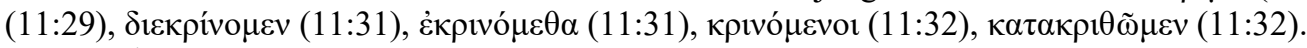

${ }^{476}$ Garland, 1 Corinthians, 551-52.

${ }^{477}$ Kapferer, "Virtuality," 672-73.

478 Ibid., 682.

${ }^{479}$ Ibid., 682. 
revolves around the issue of emergence, that which happens by virtue of performance: an irreversible quality of experience or situation that the participant has experienced. ${ }^{480}$ The experience of communitas becomes historical emergence if the ritual works. The success of ritual hinges on factors such as performative authority and contingency. Finally, the movement of historical-social reality that emerges in the ritual into the domain of social event constitutes the movement of ritual symbolism or efficacy into the human world.

The entry point into the virtual space created by the eucharistic ritual can be detected by Paul's use of Korvøvía in association with the Lord's Supper: "The cup of blessing that we

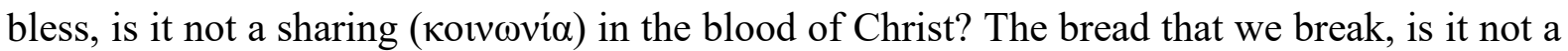

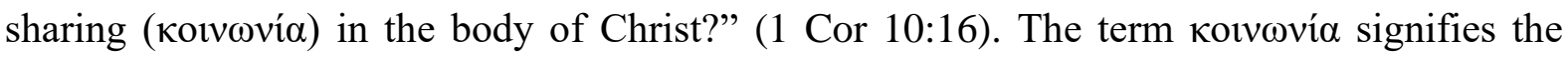
personal participation in the life of Christ, since bread and wine symbolise in the sacrificial meal the victimhood of Christ crucified. ${ }^{481}$ Being the victim in the sacrifice, Christ mediates between the sacred and profane realms as a conduit of religious power. ${ }^{482}$ Granted, as Mary

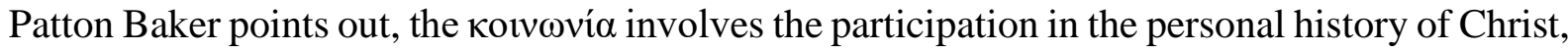
especially the death and suffering of Christ (1 Cor 2:2; Rom 8:17; 2 Cor 1:7). ${ }^{483}$ Nevertheless, sharing in Christ's suffering and death relates to the imitation of Christ event whereas the

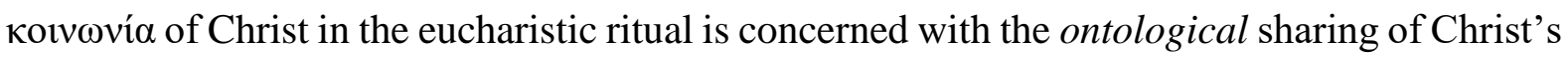
very life. In fact, the sharing of the Christ event finds its locus in the Lord's Supper ritual from which participation in the personal history of Christ flows.

The virtuality of the eucharistic ritual created through the fellowship with Christ the victim is a space in which the participants can overcome the constraints or determinants that inhibit them from achieving their true potentiality; namely, becoming a member of Christ's body (1 Cor 12). The determinants that threaten this potential include the factions in the Corinthians community whose leaders have the gift of the Spirit, the tolerance of sexual immorality, legal disputes amongst the members of the community, and the disorderliness of worship. All these determinants have the same underlining cause: the fragmentation of the community. The virtual space afforded by the meal ritual is a place in which the fragmentation is healed and made whole. That healing is made possible by the supernatural food provided at

\footnotetext{
${ }^{480}$ Schieffelin, "On Failure and Performance," 64.

${ }^{481}$ Whilst this interpretation of the Lord's Supper appears to present only one particular view of eucharistic theology, we are by no means implying the doctrine of transubstantiation that was formulated in the thirteenth century. This is the result of using ritual insights that see the objects used in the religious ceremony as a metaphor or metonymy that actualises the image plan of each scene of the ritual performance. See section 2.2 above for a discussion on metaphor predicates in rituals.

${ }^{482}$ Hubert and Mauss, Sacrifice.

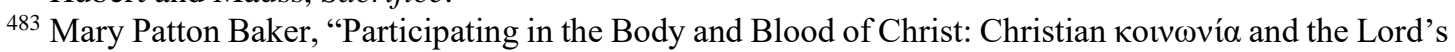
Supper," in "In Christ" in Paul, ed. Michael J. Thate et al., WUNT 384 (Tübingen: Mohr Siebeck, 2014 ), 511.
} 
the meal ritual that sustains the life of the Corinthian community. Paul alludes to the food and drink with which the Israelites of old sustained them in the wilderness. In a Midrashic manner, Paul reads the Lord's Supper ritual into the old story, interpreting the manna and water as supernatural food and drink, which are bread and wine in the ritual. What is conveyed through the bread and wine is the life of Christ that constitutes the $\sigma \tilde{\omega} \mu \alpha$ of the Corinthians that is shown in "the dual identification of the body as both Christ's sacrificial presence and those who partake of his body": 484

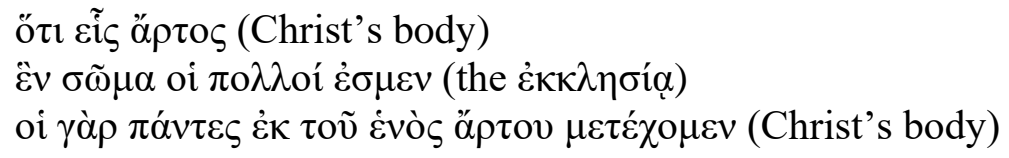

This is confirmed by the meal formula found in Joseph and Aseneth, an apocryphal Old Testament work that fills in the gap in the Genesis story of how the daughter of an Egyptian priest could marry Joseph, the patriarch. ${ }^{485}$ In six instances that occur throughout this work, the meal formula imbues bread and cup with the ability to impart immortality and incorruptibility. ${ }^{486}$

\begin{tabular}{lll} 
Verse & Bread & Cup \\
\hline $8: 5$ & Blessed bread of life & Blessed cup of immortality \\
$8: 9$ & Bread of life & Cup of blessing \\
$15: 5$ & Blessed bread of life & Blessed cup of immortality \\
$16: 16$ & Bread of life & Cup of immortality \\
$19: 5$ & Bread of life & Cup of blessing \\
$21: 21$ & Bread of life & Cup of wisdom
\end{tabular}

Aseneth, the wife of Joseph and blessed by God from birth, is sustained by properly blessed bread, cup, and ointment through which life, immortality, and incorruptibility become part of her qualities. ${ }^{487}$ Similarly, Paul's meal formula in 1 Cor 10:3, 16, 17, 11:23-26, and 12:13 may

\footnotetext{
${ }^{484}$ Baker, "Participating," 523.

485 Christoph Burchard has demonstrated the relevance of using the Joseph and Aseneth text in interpreting the use of bread and cup in association with Christ: "What JosAs can do perhaps is to help explain why the central rite of that new religious movement, Christianity, was a solemn form of consuming ö $\rho \tau$ s $\varsigma$ and

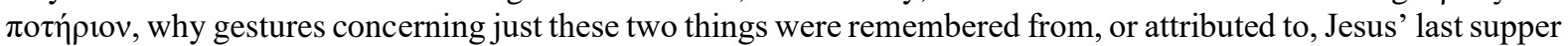
(such gestures are what Mark 14:22-24 par. is about, after all, not a meal), and why a narrative concerning them was formed at all"; See Christoph Burchard, "The Importance of Joseph and Aseneth for the Study of the New Testament: A General Survey and a Fresh Look at the Lord's Supper," NTS 33, no. 1 (1987): 118-19.

${ }^{486}$ Kirsten Marie Hartvigsen, "The Meal Formula, the Honeycomb, and Aseneth's Transformation," in The Eucharist-Its Origins and Contexts: Sacred Meal, Communal Meal, Table Fellowship in Late Antiquity, Early Judaism and Early Christianity, Volume I, ed. David Hellholm and Dieter Sanger (Tübingen: Mohr Siebeck, 2017), 227-28.

${ }^{487}$ Hartvigsen, "The Meal Formula," 247.
} 
have been shaped by Joseph and Aseneth, which would explain his designation of food and drink as supernatural, as they provide life to the participant.

In this virtual space, past, present, and future events are concurrently presented to the participants; the virtual space is ahistorical, outside of the confines of time. We have discussed earlier in section 3.5.2 that the myth embedded in the eucharistic ritual is founding a new community, complete with ratification by a sacrifice. In this imaginary ritual space, the participants are identified with this event in the past. This is shown in all three references to the Lord's Supper in 1 Corinthians. In 1 Cor 5:7-8, which relates the action of the celebration of Passover to the present context of the Corinthian community, Paul states that Christ the Paschal lamb has been sacrificed and in the same breath exhorts the Corinthians to celebrate the festival appropriately. Note that the verb $\dot{\varepsilon} \rho \rho \tau \dot{\alpha} \zeta \omega \mu \varepsilon v$ is in the subjective hortatory mood, which indicates that the sacrificial meal in which Christ is the victim does not happen in the

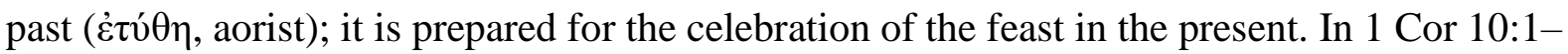

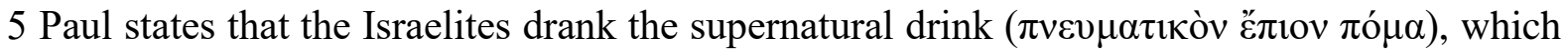
happened in the past. When linking this passage with 12:13, in which the parallel phrase $\tilde{\varepsilon} v$ $\pi v \varepsilon \tilde{v} \mu \alpha \dot{\varepsilon} \pi \circ \tau i ́ \sigma \theta \eta \mu \varepsilon v$ occurs, the experience of the Israelites is made contemporary with the experience of the Corinthians. Finally, in 1 Cor 11:26 Paul links the present moment with the

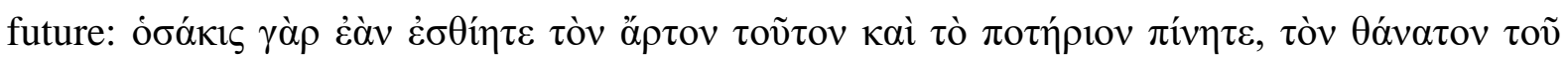

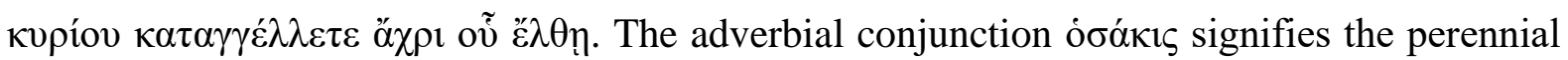
celebration of the rite in the present that will meet with the future of öx $x \rho$ oṽ $\varepsilon \lambda \theta \eta$, the orientation of the ritual.

Having examined the virtual space created by the eucharistic meal, our discussion now moves to the second aspect of transformation that takes place at the ritual performance: historical emergence. What arises out of the meal ritual is the experience of communitas on the part of the participants, which is the efficacy of the ritual. To determine that efficacy, one needs to examine what impact this ritual has on society at large. In his In the Beginning was the Meal, Hai Taussig has observed that the meal rituals amongst the association gatherings constitute a subtle resistance movement to the imperial Roman power, as the meal creates an imaginative power that can renegotiate the current social order. ${ }^{488}$ At Hellenistic meals, the inequality amongst the various social classes are eliminated, the values of equality such as isonomia and philia are upheld, the ritual libation presents an opportunity for participants to shift their

${ }^{488}$ Hal Taussig, In the Beginning Was the Meal: Social Experimental and Early Christian Identity (Minneapolis: Fortress Press, 2009), 118-24. 
allegiance from the emperor to others, experiments with kinds of power other than the imperial model are entertained, and disturbances are tolerated to model ways for diverse populations to relate to one another. ${ }^{489}$ Similarly, the meal ritual in the Christ religion exhibits some of these characteristics, especially in its cosmology and the crucifixion of Christ. Just as the Hellenistic meals express utopian hopes, Christ followers likewise re-imagine a new cosmic vision in which Christ, not the Roman emperor, rules over creation. This vision is expressed in the Christ hymns used at the communal meal (John 1:1-4, 8-14, 16-18; Col 1:15-20; Phil 2:6-11; Rom 11:33-36; 1 Tim 3:16; 6:15, 16). ${ }^{490}$ The crucifixion of Christ ritualised in the meal constitutes another element of resistance to Roman domination. This is demonstrated in four ways: libations, songs, blessing the bread, and storytelling and teaching during the meal. ${ }^{491}$ As to the libations, the wine is compared to the blood of the executed Jesus to indicate that a new covenant is evoked, asserting a social loyalty to the association and indicating resistance to Roman rule (Mark 10:35-40; 14:24; Matt 26:28). ${ }^{492}$ The songs accompanying the meal ritual depict the alternative cosmic reign of Jesus, who brings about a new world and salvation that contradict the present order (Phil 2:6-11; Col 1:15-20). ${ }^{493}$ The blessing of the bread at the meal gathering re-enacts the crucifixion of Jesus, the martyr and the source of etiological myth (1 Cor 11:23). ${ }^{494}$ Finally, the storytelling and teaching during the meal's symposion evoke the death of Jesus by reinforcing "the expressions of resistance to Roman arrogance and imperiousness." ${ }^{495}$ By adopting the Hellenistic meal traditions and recasting them into the Christ religion's cultic meal ritual, early Christ followers are creating a new society that inverts the present values and order.

\subsubsection{Relationality}

In this final ritual analysis section, the discussion focuses on the special relationships that emerge from the ritual performance. One of the realities that rituals enact is relationships: "an ongoing reciprocal involvement between subjects implying, for all parties concerned, the attendant qualities of agency, interaction, intentionality, affect and accountability." 496 The special relationships emerging from rituals have three characteristics. First, ritual relationships

\footnotetext{
489 Taussig, In the Beginning, 122-24.

${ }^{490}$ Ibid., 104-12.

${ }^{491}$ Ibid., 125-39.

492 Ibid., 131-35.

493 Ibid., 135-36.

${ }^{494}$ Ibid., 136-38.

495 Ibid., 139.

${ }^{496}$ Houseman, "Relationality," 415.
} 
are not reducible to logical or metaphysical connections between abstract terms. Instead, they are deemed to be "lived-though experiences sustained by intentionally and emotionally laden events." The relationships are lived events and personally invested. Second, the relationships the participants enact involve both humans (with one another) and non-human entities (gods, sprits, objects, etc.). The relationships with non-human entities depend on the network of relationships involving human participants. Third, the modifications of ordinary behaviours in a ritual come from the relational configuration in the ritual, which is "systematically orchestrated in a mutually reinforcing fashion." The emerging effects from the relational configuration in a ritual results in the recontextualisation of multiple characters in ritual actions and the integration of disparate elements.

The ritual relationships emerging from the meal ritual in the Christ religion have two aspects: one on the vertical and one on the horizontal plane. The former relates to the relationships of the participants as a group to God; the latter refers to the relationships amongst the participants.

To understand the kind of ritual relationships emerging from the eucharistic ritual on the vertical plane, the discussion turns to Paul's description of the relationship between God and the ekklēsia. One way Paul describes the relationship is through the use of nuptial imagery. In 2 Cor 11:2 Paul states, "I feel a divine jealousy for you, for I promised you in marriage to one husband, to present you as a chaste virgin to Christ." ${ }^{297}$ This nuptial imagery between God as the bridegroom and the people as the bride has precedent in the Old Testament, from which New Testament writers draw so much inspiration and material. The ideal relationship between God and Israel is a marital union between the two: God demands fidelity to him of Israel, and Israel expects divine love and care in recompense (Isa 54:6; 61:10-62:5; Hos 2; Ezek 16:752 ). The union between God and his people in bridal or male-female imagery also appears in post-biblical Judaism (Joseph and Aseneth 21:3; Ode 3:5-8; 28:7-8; 42: 2-3, 7-9; 4 Ezra 9:3810:54). For instance, 4 Ezra 9:38-10:54 contains a highly developed nuptial metaphor on the divine faithfulness to the covenant he made with Israel. The city Zion in the pericope represents a female/mother who mourns for the destruction of her city (10:20-24). God, the husband of the personified woman, Zion, loves his bride more than anything else (4 Ezra 8:47; cf. 3:14; $5: 33,40)$. Andre Villeneuve notes that the historical dimension of the parable spanning from the creation of the world (when Zion have existed since) and to various key historical moments in which God stipulated various covenants with Noah, Abraham, and Moses, and to Davidic

${ }^{497}$ See also Eph 5:25-32. 
Kingdom until the destruction of the city by the Babylonians (3:9-28); God manifested his faithfulness to Zion throughout all these period. ${ }^{498}$

Given the long-established use of nuptial imagery for the relationship between God and his people, it is natural that one of the avenues through which this relationship is articulated is ritual performance, specifically at the meal gathering. Although Paul does not explicitly indicate the vertical relationship entailed in the Lord's Supper, the connection between the meal ritual and the marital union with God can be made based on several imageries in the 1 Corinthians. We take Paul's warning against the fornication as a sin against one's body, and it constitutes a union with the prostitute, which is incompatible with Christ's members as a point of departure (1 Cor 6:15-20). In this passage we highlight three different but related imageries: body/temple, Christ, and sexual immorality. First, the imageries of body and temple are being employed throughout the letter in addressing various issues, including the identity of Corinthian communities. For example, Paul uses Temple image to describe the intimate relationship between the holy spirit and the Christ believers: "Do you not know that you are God's temple and that God's Spirit dwells in you? If anyone destroys God's temple, God will destroy that person. For God's temple is holy, and you are that temple (3:16-17)." The Temple of God refers to the believing communities, and their union with God is depicted in terms of encounter between God and his people in a physical Temple. Second, in chapter 15, Paul assigns Christ as the new Adam in his discussion of eschatology and the bodily resurrection (15:22). In contrast to first Adam as a living being that corrupts, Christ, the last Adam, receives incorruptible body in glory ( $\delta$ ó $\xi \alpha 15: 43$ ). This begs the question: since Christ is the new Adam, who is the new Eve? Villeneuve deduces from the following information in the epistle that the ekklesis would fulfil Eve's role: “ ... if we consider that "woman came from man" (i.e. Eve from Adam, 11:8), that man is the $\delta$ ó $\xi \alpha$ of God and woman the $\delta$ ó $\xi \alpha$ of man (11:7), and that the Church is Christ's body $(10: 17 ; 12: 27)$, ... which will inherit his life and $\delta$ ó $\xi \alpha(15: 49)$, we come very close to the concept of the Church as "new Eve, the bride ... ." ${ }^{499}$ Finally, Paul's admonition against $\pi$ opveía alludes to the marriage between Christ and his believing communities who are incorporated into Christ's body through baptism and sanctified. Thus, the baptised Corinthians can no longer be joined to a prostitute through an illicit sex, since it constitutes an offense against one's body, the Temple of the Spirit, which signifies " a "sacred

${ }^{498}$ Andre Villeneuve, Nuptial Symbolism in Second Temple Writings, the New Testament, and Rabbinic Literature: Divine Marriage at Key Moments of Salvation History (Leiden: Brill, 2016), 282.

${ }^{499}$ Villeneuve, Nuptial Symbolism, p 202 
space" where God meets man and enters into communion with him." 500 Taking all these observations together coupled with Paul's statement in 1 Cor 10 on the partaking of meal at demons' table, a clear nuptial imagery at the Lord's Supper emerges: Christ, the new Adam, meets his brides, the ekklesia in the Temple indwelled by the Spirit at the Table of the Lord's

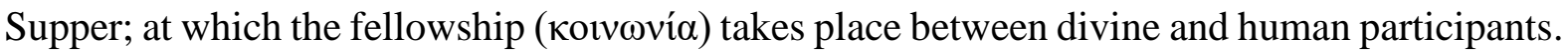

The horizontal relationships emerged from the meal ritual are articulated in terms of $\sigma \tilde{\omega} \mu \alpha$. The body refers to both Christ himself and the members of the Corinthian community who are members of Christ's body. The bread that Corinthians partake of in the meal is identified with Christ's body (1 Cor 10:16; 11:26, 27), and the Corinthian community is simultaneously a body identified with Christ's (1 Cor 12:13). This dual identification of $\sigma \tilde{\omega} \mu \alpha$ intimates that the relationship with God in the ritual hinges on the network of interpersonal ties amongst the human members in Christ's body. The establishment of an intimate connection with God in the eucharistic ritual is inseparable from and depends on the network of

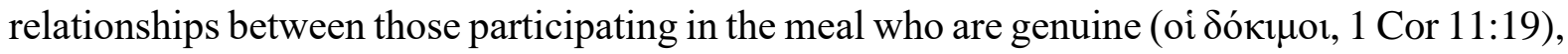

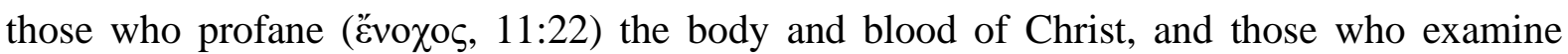

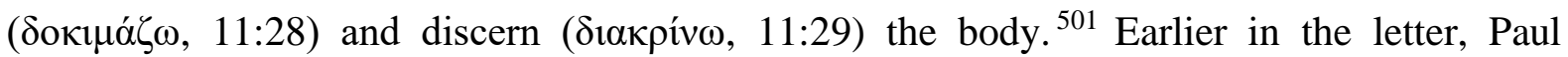
admonishes the Corinthians to resolve any legal issues amongst themselves by appointing

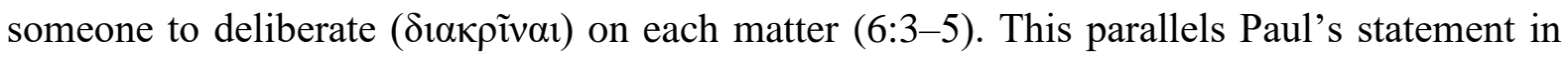

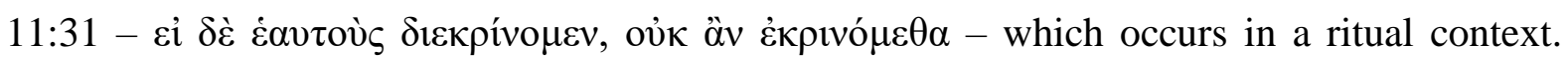
Reading this statement in view of 1 Cor 6:3-5, the Lord's Supper is a moment of judgement for the Corinthian themselves, a moment of truth for the participants that reveals whether individuals are worthy of the wedding banquet in the Kingdom of God on account of the holiness of their lives (6:9-11; Matt 25:1-13). If this reading is correct, the perplexing

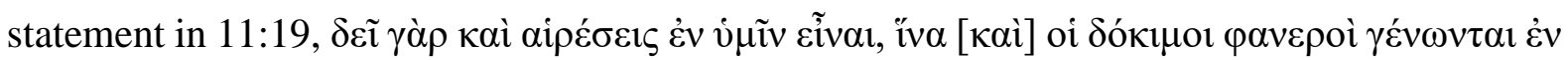
v $\mu \mathrm{i} v$, could be elucidated in light of this understanding that, at the Lord's Supper, all the controversies and issues in the Corinthian community are to be revealed and resolved, so that newly configured relationships would emerge..$^{502}$

${ }^{500}$ Ibid., 197.

501 These designations are based on the action one taken in relation to the Lord's Supper; they are not meant to be a construct of several concrete groups in the meal ritual, but a designation of various action taken relating to their disposition towards the meal. These actions are essentially fall into two categories: those who are not genuine, i.e. profaning the meal, and those who are genuine accompanied with their acts of discernment, examination.

502 Various interpretations have been offered for the exact sense of this passage. Some think that Paul says this ironically, accusing the Corinthians for their abuses at the meal; see Collins, The First Corinthians, 422 , and Lietzmann, Mass and Lord's Supper. Others think that the necessity of this faction is divinely eschatological; see Jerome Murphy-O'Connor, New Jerome Biblical Commentary, ed. R. E. Brown et al. (Englewood Cliffs, NJ: 
The eucharistic ritual realises and solidifies the identity of the Corinthians as an ekklessia. To understand how the meal ritual achieves these dual purposes, one needs to turn to the rites and ceremonies of the Greco-Roman world in antiquity that served as a unifying force amongst disparate groups of people. The relevance of bringing Greco-Roman materials to bear on the discussion is that, as part of the wider meal culture, the Christ religion shares some of the understandings of how ritual functions, including the unification of disparate members from a wide range of social classes (i.e., 1 Cor 12:12; Gal 3:26-28). Two examples can be cited. First, in $430 \mathrm{BC}$, a cult of the Thracian goddess Bendis was founded in Piraeus. ${ }^{503}$ The Athenian demos agreed to permit a foreign cult in Piraeus if Thrace would join a military alliance with Athens in the Peloponnesian War. ${ }^{504}$ Ensuring the harmonious relations be established and maintained amongst the two Thracian groups, a decree was issued mandating the Piraean association to supply sponges, cups of water, wreaths, and a meal in the sanctuary to the Athenian group. ${ }^{505}$ When they arrived at the temple, the priest and priestess offered sacrifices to the Piraean cultores:

that when these events take place and the entire ethnos lives in harmony, the sacrifices be made to the gods, and the other rites shall be offered in accordance both with the ancestral customs of the Thracians and the laws of the city and ... it will go well and piously for the entire ethnos in matters concerning the gods. (IG II $\left.{ }^{2} 1283.32-36\right)^{506}$

This text illustrates the alliance of two disparate groups through the joint offering of a sacrifice that forms a unified ethnos. Likewise, at the Lord's Supper various social groups that are otherwise separated by social, economic, and ethnic status are brought together in an alliance to form a new community or nation: "For in the one Spirit we were all baptized into one body - Jews or Greeks, slaves or free - and we were all made to drink of one Spirit." The second example is from Dionysius of Halicarnassus's Antiquitates romanae; it illustrates how the unity of various cities in Greece was maintained through the joint effort of religious rites and ceremonies. The Ionians, imitating Amphictyon, the son of Hellen, who assembled a general

Prentice Hall, 1990), 809, and Gordon D. Fee, The First Epistle to the Corinthians, NICNT, Grand Rapids: Eerdmans, 1987), 538. A recent proposal by R. Alastair Campbell sees the passage functioning as evidence of

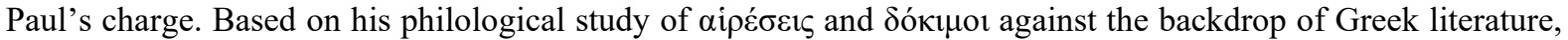
Campbell renders this passage as follows: "For there actually has to be discrimination in you that if you please the elite may stand." See R. Alastair Campbell, "Does Paul Acquiesce in Divisions at the Lord's Supper?" NovT 33, no. 1 (1991): 61-70. I suggest that elements of irony and accusation are indeed embedded in this passage, but it also has a ritual dimension, since the Corinthians have violated the ritual terms (see section 3.5.2). Regarding the eschatological aspect of this statement, I argue that the division statement is not so much a warning about the future; it happens in the present, at the Lord's Supper with its eschatological orientation.

503 Kloppenborg, "Greco-Roman Thiasoi," 214.

504 Ibid., 214-15.

505 Ibid., 215.

506 Ibid., 215. 
council of the whole nation to establish a law that allowed the cities to live in harmony against the barbarians, establish the custom of an annual religious festival where representatives from each city would come and join in a common sacrifice:

\begin{abstract}
The Ionians building the temple of Diana at Ephesus and the Dorians that of Apollo at Triopium - where they assembled with their wives and children at the appointed times, joined together in sacrificing ( $\sigma v v \varepsilon \dot{\theta} \theta 0 \mathrm{v}$ ) and celebrating the festival, engaged in various contests, equestrian, gymnastic and musical, and made joint offerings ( $\dot{\alpha} v \alpha \theta \eta \dot{\eta} \mu \alpha \sigma$ kotvoĩ $\varsigma$ ) to the gods. After they had witnessed the spectacles, celebrated the festival, and received the other evidence of goodwill from one another, if any difference

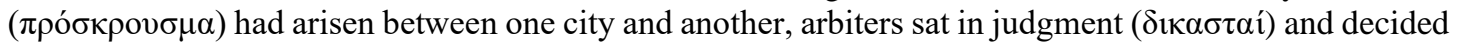
the controversy; and they also consulted together concerning the means both of carrying on the war

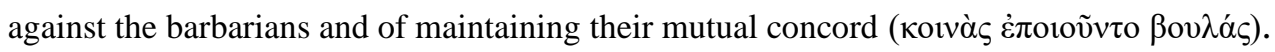

... he advised them to build a temple of refuge at Rome at their joint expense, to which the cities should

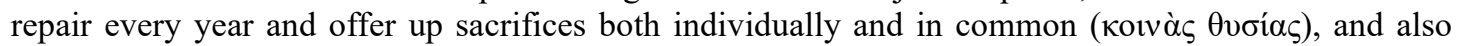
celebrate festivals at such times as they should appoint; and if any difference ( $\pi \rho$ ó $\sigma \kappa \rho o v \sigma \mu \alpha)$ should arise between these cities, they should terminate it over the sacrifices, submitting their complaints to the rest of the cities for decision. ${ }^{507}$
\end{abstract}

Note that the sacrificial language in this text has striking similarities with that of 1 Cor 10 and 11 in both the action of the sacrifice and the theme of unity amongst the assembled. Regarding

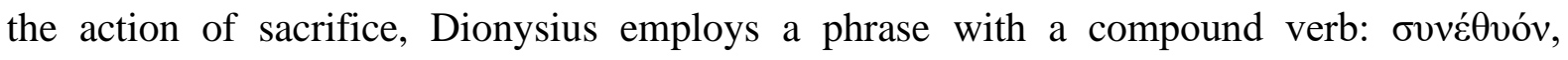

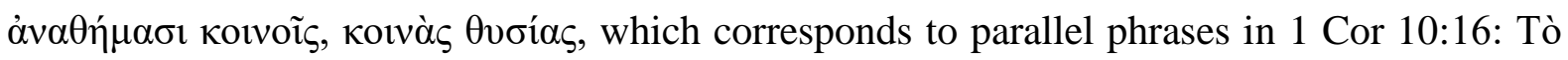

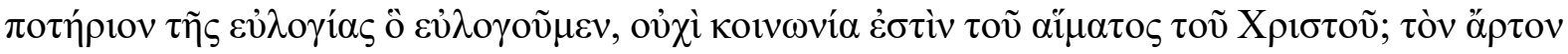

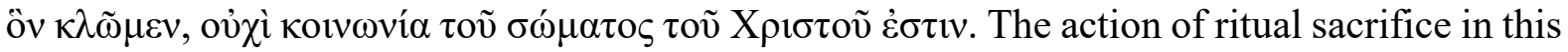
passage is indicated not by a verb of sacrifice, but by linking of the blessings of cup and bread

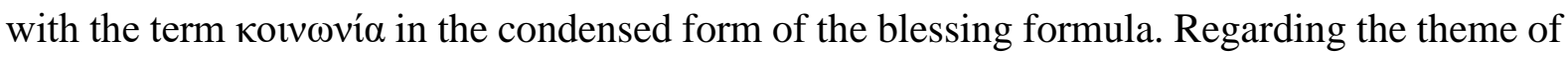
unity, the Dionysius text uses the term $\pi \rho \sigma_{\sigma \kappa} \rho о v \sigma \mu \alpha$, which has the sense of obstacle or stumbling block to signify that which threatens the unity of the assembly. Similarly, Paul in 1

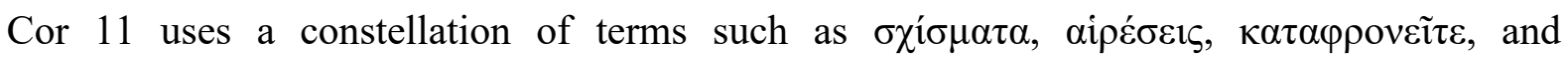

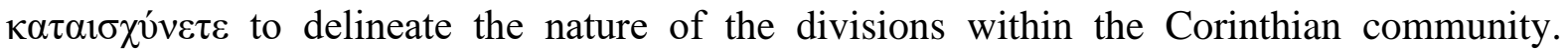
Furthermore, both texts use the term $\delta 1 \kappa \alpha \sigma \tau \alpha$ í with regard to resolving the issues that have arisen amongst the members of the two communities. This analysis shows that the sacrificial meal serves as a locus for alleviating conflicts amongst various groups by incorporating them into a common identity. Thus, the Lord's Supper serves the dual purposes of exposing problems and conflicts amongst disparate groups and of healing the broken body by incorporating it into the liminal state of a new society.

Using ritual performative theories supplemented with a sacrificial interpretation of the Lord's Supper, this discussion has demonstrated the manner and process in which the meal

${ }^{507}$ Dionysius, Ant. rom 4.25.5-6, 26.3. 
ritual facilitates a union with Christ. The process begins with the celebrant of the rite, the paterfamilias, who initiates the ritual performance. During the performance, the myth accompanying the ritual and the moral discourse encoded therein re-establish the primordial order in form and substance and the moral conditions for the participants. At the culmination of the performance, the participants enter a virtual space in which a union with Christ occurs through the partaking of Christ's very life in the form of bread and wine. What emerges from this re-imagination of the participants' worldview is the experience of a new society that is opposed to the present order and a transfigured relationship with God and their fellow human beings.

\subsection{Conclusions}

Several observations emerge from the ritual analysis of the Lord's Supper ritual. First, the Lord's Supper ritual and the institution narrative are intimately related as to form and substance, word and action, which are re-united in the ritual performance. Second, the Lord's Supper is both a meal and a commemoration of Christ's sacrificial death in the imagery of the Paschal lamb, since it is part of the wider meal banquet motif in the Greco-Roman world, where a sacrifice was followed by a communal meal. Third, the Lord's Supper establishes the moral imperatives for the participants, as it is a moment of judgement for all involved; their problems and conflicts are laid bare against its terms and resolved by re-configuring the relationships amongst the members of the body. Finally, the Lord's Supper allows the possibility of imaging a virtual space wherein the participants are presented with the salvation history of past, present, and future, facilitating the process of re-orientation of the self with regard to the perception of the worldview and the process of re-creation of the self by partaking of Christ's body and blood, resulting in transfigured relationships with God and human beings. 


\section{Chapter 4 \\ The Ritual Dimension of Paul's Participatory Language}

\subsection{Introduction}

In the previous two chapters, the present study has focused on the rituals of baptism and the Lord's Supper themselves, drawing from the ritual transformation model to show how rituals facilitate transformation amongst the participants. Starting with this chapter, the approach develops beyond the application of the ritual transformation model. The study now focuses on the participatory language itself, paying attention to the exegetical issues surrounding the ritual or sacramental aspect of union with Christ before examining its relation to the role of faith in the process of participation in Christ.

The issue of the relationship of sacraments to union with Christ has been raised in previous scholarship. However, it has not received a satisfactory resolution; either the relationship is downplayed by rehashing the same argument that faith alone unites the believer to Christ, or the relationship that is acknowledged between baptism or the Lord's Supper and union with Christ is often not adequately defended. Obviously, choosing a stance in this debate can align with one's theological tradition, and the debate has appeared to be locked in a theological labyrinth with no clear way out. Indeed, it may be this theological impasse that explains why the issue has not been confronted more often and more openly. The aim of this chapter is to provide a neutral ground for exploring this issue by proposing that the sacraments should be approached from the perspective of ritual study. Instead of using the theological category of sacraments, which is laden with doctrinal debates - like the real presence of Christ in the Lord's Supper - that were developed after the nascent period of the Christ religion, the employment of ritual models or theories from anthropology to the study of baptism and the Lord's Supper and their relation to the process of transformation and union with the divine will focus on the ritual functions of these two important rituals in the life of the nascent Christ movement.

This chapter develops in three stages. First is a consideration of the application of ritual insights to participatory language, including the reasons for choosing that approach. Second, the study focuses on the syntactical analysis of key passages that contain participatory language and ritual references: Rom 6:2-8; 1 Cor 10:14-22; 11:24-25; 12:13; Gal 3:26-28. Lastly, the study applies ritual transformation models to these key passages. 


\subsection{The Application of Ritual Insights}

The interpretations of participation in Christ fall into several categories: spirit participation, temporal/Christ event participation, and corporate participation. The earlier strand of the category of spirit participation identifies kv́ploৎ with $\pi v \varepsilon \tilde{u} \mu \alpha$ in 2 Cor 3:17 as the key to understanding Paul's mystical communion with Christ. In this line of thought, Christ is thought of as a supra-terrestrial power that fills the presence of Paul and his whole life, which is

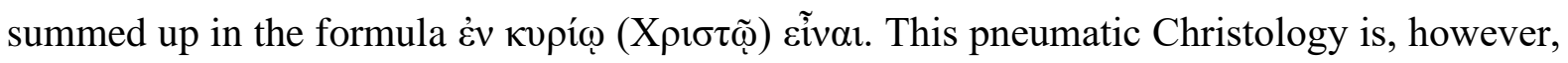
called into question by Friedrich Büchsel, who rejects $\dot{\varepsilon} v$ 's having a local sense, $\chi \rho ı \tau$ ó $\varsigma$ as pneumatic, and $\dot{\varepsilon} v \chi \rho ı \tau \tilde{\Phi}$ as a formula. ${ }^{508}$ For Büchsel, the "in Christ" language is contextual and depends on each instance of Paul's usage. In more recent research, there is a clear delineation between the person of Christ and the Spirit, with the latter being a physical entity that infuses the individual to effect fellowship with Christ. Borrowing from Greco-Roman medical and philosophical (particularly Stoic) conceptions of $\pi v \varepsilon \tilde{u} \mu \alpha$ as "a physical entity, matter ... air or breath, or "the very particles which make up the soul," argues that $\pi v \varepsilon \tilde{v} \mu \alpha$ is a material substance that is infused into believers by Christ, creating a new kinship that connects them to Abraham as their ancestor. Stowers echoes this understanding that $\pi v \varepsilon v \tilde{u} \mu \alpha$ is the divine "stuff" that is granted to Christ at his resurrection and the means by which the Gentiles gain entry into the physical lineage of Abraham.

The second category of participation is pertinent to the Christ event. Taking great pains to distinguish Hellenistic mysticism from Pauline mysticism, Schweitzer holds that the differences lie in the messiah myth of the Jewish eschatology of Paul's era, which entails the notion of a "preordained" union of the elect with the messiah. The unanticipated Christ event - his advent, death, and resurrection - can be elucidated by "Christ Mysticism," whose fellowship with the Messiah already manifests itself in this world and the Elect, like Christ, are a supernatural being. Rejecting the conflation of the phrases $\dot{\varepsilon} v \chi \rho i \sigma \tau \tilde{\varphi}$, $\dot{\varepsilon} v \kappa v \rho i \tilde{\omega}$, and $\dot{\varepsilon} v$ $\pi v \varepsilon v ́ \mu \alpha \tau$, Fritz Neugebauer asserts that $\chi \rho ı \sigma \tau$ ć $\varsigma$ should only denote the crucified and risen Christ. Accordingly, $\dot{\varepsilon} v$ should be interpreted historically, making "in Christ" mean to be determined by (bestimmt sein durch) the eschatological events of the cross and then

${ }^{508}$ Friedrich Büchsel, “'In Christus' bei Paulus,” ZNW 42 (1949): 141-58.

${ }^{509}$ Caroline Johnson Hodge, If Sons, Then Heirs: A Story of Kinship and Ethnicity in the Letters of Paul (Oxford: Oxford University Press, 2008), 74. See also Dale B. Martin, The Corinthian Body (New Haven: Yale University Press, 1995) and Troels Engberg-Pedersen, Cosmology and Self in the Apostle Paul: The Material Spirit (Oxford: Oxford University Press, 2010). On potential problems with the applicability of this view to Paul, see Volker Rabens, The Holy Spirit and Ethics in Paul: Transformation and Empowering for Religious-Ethical Life, WUNT II 283 (Tübingen: Mohr Siebeck, 2010), and John M. G. Barclay, "Stoic Physics and the Christ-event: A Review of Troels Engberg-Pedersen, Cosmology and Self in the Apostle Paul: The Material Spirit (Oxford: Oxford University Press, 2010)," JSNT 33 (2011): 406-14. 
resurrection, to be included in this "history." 510 Finally, Bouttier connects the historical and eschatological aspects of participation to form a complete timeline of salvation history. Framing $\dot{\varepsilon} v \chi \rho ı \tau \tilde{\omega}$ and $\dot{\varepsilon} v \kappa v \rho i ́ \omega$ as a difference between "indicative" and "imperative," Bouttier argues that "in Christ" encompasses the totality of redemption history, ranging from the past in the historical event of death and resurrection of Christ, to the present of Christ sitting at the right hand of the father, and to the future advent of Christ. ${ }^{511}$

The third category of participation is corporate identity, under which scholars tend to hinge the notion of participation in Christ on the Old Testament ideas of representation and corporate identity. A. J. M. Wedderburn notes the conceptual analogy between Abraham and Christ in Gal 3, articulated in the verbal parallelism between $\dot{\varepsilon} v$ ooí and $\dot{\varepsilon} v \chi \rho\left\llcorner\sigma \tau \tilde{\varphi} .{ }^{512}\right.$ Wedderburn argues that since it is impossible to conceive of being "in Abraham" as having spatial and ontological categories, the most likely explanation would be interpreting $\dot{\varepsilon} v$ бoí in an instrumental sense: by means of Abraham, humanity is blessed. ${ }^{513}$ Likewise, it is by means of Christ that the rest of humanity is blessed. W. D. Davies, unsatisfied with Schweitzer's messiah concept of the predestined union of the elect with the messiah, offers an alternative theory to the messiah's role as "the representative leader and head of Israel." 514 Thus, according to Davis, Paul's “in Christ" language denotes an individual who accepts Christ becoming part of a new humanity with Christ as the head of the true Israel of God, making Christ's history their own history. ${ }^{515} \mathrm{~N}$. T. Wright locates the messiah's corporate role in the Old Testament background of kinship, in which the king and the people are bound together so closely that what is true of one is true of the other. 516

Although these categories expound different aspects of participation in Christ, they can be bound together through the ritual concept. The categories remain in the realm of cognitive

${ }^{510}$ Fritz Neugebauer, “Das Paulinische “in Christō,"” NTS 4, no. 2 (1958): 132.

${ }^{511}$ It is literally to be taken up into "[être entraîné dans] his story-past, present, and future!" Michel Bouttier, En Christ: étude d'exégèse et de théologie pauliniennes (Paris: Presses universitaires de France, 1962), 97, 133.

${ }^{512}$ A. J. M. Wedderburn, "The Body of Christ and Related Concepts in 1 Corinthians," SJT 24 (1971): 74-96, especially 86-90; cf. Ernst Käsemann, "The Theological Problem Presented by the Motif of the Body of Christ," in Perspectives on Paul, trans. Margaret Kohl, NTL (Edinburgh: SCM, 1971), 102-21.

513 Wedderburn, "Body of Christ," 89.

${ }^{514}$ W. D. Davies, Paul and Rabbinic Judaism: Some Rabbinic Elements in Pauline Theology, 3d ed. (London: SPCK, 1970), 99-100.

515 Davies, Paul and Rabbinic Judaism, 107.

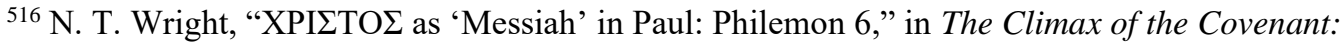
Christ and the Law in Pauline Theology (Edinburgh: T\&T Clark, 1991), 41-55; cf. "The Messiah and the People of God: A Study in Pauline Theology with Particular Reference to the Argument of the Epistle to the Romans" (D.Phil. thesis, Oxford University, 1980), 273n68. See also Thomas Hewitt and Matthew V. Novenson, "Participationism and Messiah Christology in Paul," in God and the Faithfulness of Paul: A Critical Examination of the Pauline Theology of N. T. Wright, ed. Christoph Heilig et al., WUNT II 413 (Tübingen: Mohr Siebeck, 2016), 352-71. 
concepts that lack physical embodiments of how various modes of participation take place, whereas ritual is the physical expression that incarnates these varied notions of participation in Christ. This observation gains support from Rappaport's observation of the relation between the canonical message encoded in the ritual and the material representation thereof. ${ }^{517} \mathrm{He}$ notes that if abstract concepts such as rank or honour are to be taken seriously, their representations or signs need to be substantiated in material objects. ${ }^{518}$ The verbal pronouncement of these concepts only brings about a conventional effect, but the physical display of them presents a material fact. ${ }^{519}$ Similarly, the various concepts of modes of participation in Christ have corresponding ritual functions, which we have examined in chapters two and three.

\begin{tabular}{|lc|}
\hline Different Modes of Participation in Christ & Ritual Functions \\
Spirit & Divine agency \\
Christ event & Entailments and transformation \\
Corporate identity & Emergence and relationality \\
\hline
\end{tabular}

The category of spirit participation corresponds to divine agency, where the Spirit and Christ initiate the ritual action, the category of temporal/ Christ event participation to entailment (i.e., myth) and transformation, and the category of corporate participation to emergence and relationships. It is through baptism and the Lord's Supper that Christ in the person of paterfamilias infuses the Spirit into the believers, that the Christ myth is enacted in verbal and specialised gestures of the ritual, that the transformation takes place in a liminal state that is outside of historical time, and that a new social identity is formed, resulting in a newly configured relationship.

While there may not be a precise one-to-one correspondence between the results from the exegetical analysis of these participation categories and that of ritual analysis, they do share the same categories. Nonetheless, the aim of this study is to demonstrate that adding ritual to these various modes of participation as a common denominator will pave the way to an aspect of participation that has seldom been studied.

Furthermore, adding the ritual category to the study of participation helps mediate between the two extreme approaches that mark the scholarship in this area: the mystical and literal or realistic approaches. The earlier scholarship is fraught with mystical interpretations

\footnotetext{
${ }^{517}$ Rappaport, Ritual and Religion, 141-44.

518 Ibid., 141.

${ }^{519}$ Ibid., 143.
} 
of "in Christ" language, citing evidence from Hellenistic mysticism as support. This approach was championed by the likes of G. Adolf Deissmann, Wilhelm Bousset, and Albert Schweitzer. However, beginning in the mid-twentieth century, the trend has been to reject such mystical interpretations, opting instead for a historical-grammatical approach that emphasises linguistic and historical investigations of related prepositions in connection to Christ and biblical precedent for such usage. This view is represented by A. J. M. Wedderburn, Udo Schnelle, Fritz Neugebauer, W. D. Davies, and others. The overreaction to the mystical approach has led to the marginalisation of the ritual in the experience of participation, resulting in the denial of a ritual background behind the baptismal language in Paul. To do justice to both aspects of participation, the ritual approach is the way forward because of how it mediates between the physical and spiritual realms.

\subsection{The Syntactical Analysis of the Ritual Aspect of Participatory Language}

There have been numerous works analysing "in Christ" language through the grammatical study of the prepositions that form the phrases "in Christ", "through Christ", and "with Christ." However, all these studies have neglected the ritual language in conjunction with the participatory language; the table below evinces the close relationship between the two.

\begin{tabular}{|c|c|c|}
\hline & Ritual & Participatory language \\
\hline 1 Cor $12: 13$ & $\dot{\varepsilon} \beta \alpha \pi \tau i ́ \sigma \theta \eta \mu \varepsilon \nu$ & $\varepsilon i \zeta \tilde{\varepsilon} \nu \sigma \tilde{\omega} \mu \alpha$ \\
\hline Gal 3:26-28 & $\dot{\varepsilon} \beta \alpha \pi \tau i ́ \sigma \theta \eta \tau \varepsilon$ & 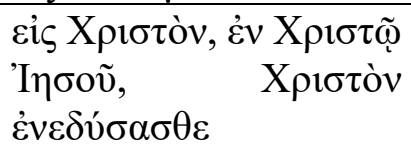 \\
\hline Rom 6:3-8 & 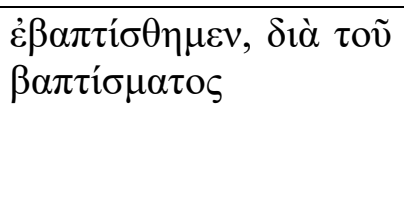 & 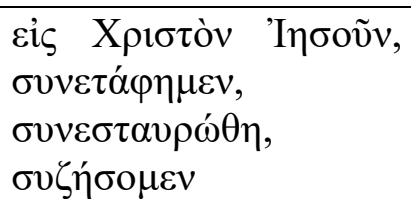 \\
\hline 1 Cor $10: 14-22$ & 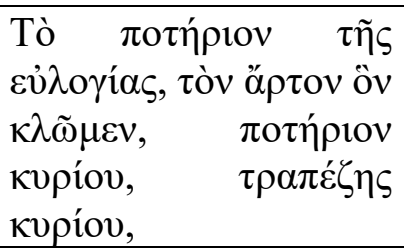 & 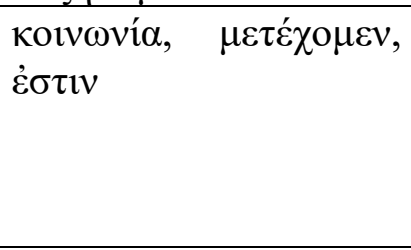 \\
\hline 1 Cor $11: 24-25$ & 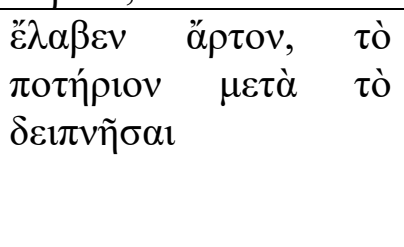 & 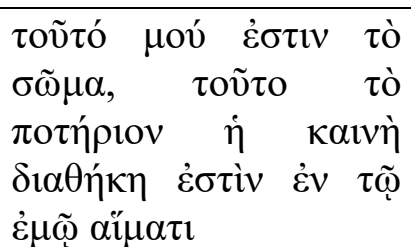 \\
\hline
\end{tabular}

The remainder of this section is dedicated to demonstrating the close connection between ritual and union with Christ through a syntactical analysis of texts that contain both baptism or the Lord's Supper and the participatory language. 


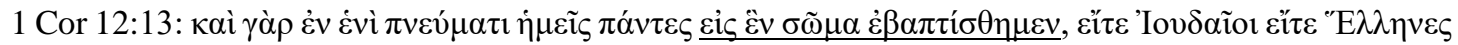

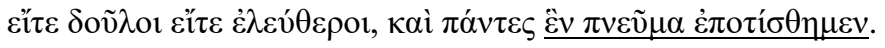

For by one Spirit we were all baptized into one body - Jews or Greeks, slaves or free -and all were made to drink of one Spirit.

The prepositional phrase $\varepsilon i \zeta \zeta \tilde{\varepsilon} v \sigma \tilde{\omega} \mu \alpha$ is the object accusative case of the verb $\dot{\varepsilon} \beta \alpha \pi \tau i ́ \sigma \theta \eta \mu \varepsilon v$. The action of baptism has its goal in $\tilde{\varepsilon} \nu \sigma \tilde{\omega} \mu \alpha$, and is a shorthand for the phrase "in Christ." Paul often employs the term $\sigma \tilde{\omega} \mu \alpha$ as a synonym for the term $\chi \rho \imath \sigma \tau o ́ c: ~ \tilde{\varepsilon} v \sigma \tilde{\omega} \mu \alpha \dot{\varepsilon} \sigma \mu \varepsilon v \dot{\varepsilon} v$

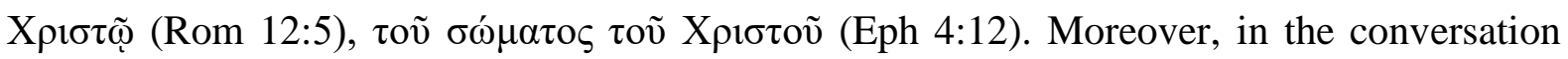
between Jesus and Paul on the road to Damascus, Jesus identifies himself with the followers whom Paul had been persecuting, revealing that $\sigma \tilde{\omega} \mu \alpha$ and Christ are inseparable (Acts 9:4-5).

The prepositional phrase $\dot{\varepsilon} v \dot{\varepsilon} v i \mathrm{i} \pi v \varepsilon u ́ \mu \alpha \tau$ is the object dative case of the verb $\dot{\varepsilon} \beta \alpha \pi \tau i \sigma \theta \eta \mu \varepsilon v$. The Spirit is the instrument or means by which one is baptised. The instrumentality of the Spirit is attested in many passages that contain different prepositional

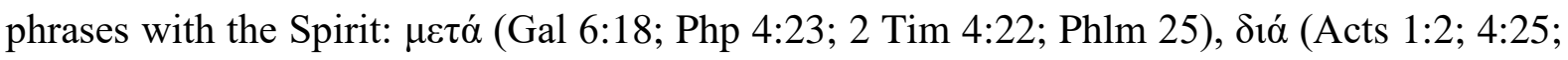
11:28; 21:4; Rom 5:5; 1 Cor 2:10, 12:8; Eph 3:16; 2 Th 2:2; 2 Tim 1:14; Heb 9:14), غ่v (Matt 3:11; 12:28; Mark 1:18; Luke 3:16; John 1:33; Acts 1:5; 11:16; Rom 1:9; 2:29; 15:16; 1 Cor 6:11; 12:9; Eph 2:22; 5:18; 1 Tim 3:16), غ̇к (1 John 3:24). Thus, the rite of baptism is administered through the instrumental power of the $\pi v \varepsilon \tilde{u} \mu \alpha$ with the aim of entering into the mysteries of Christ.

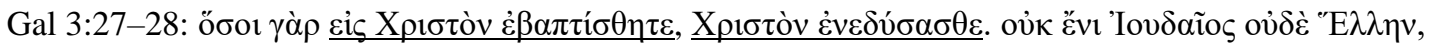

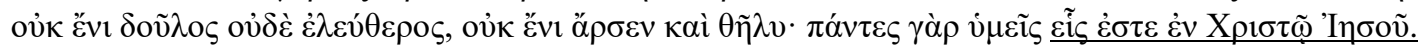

For as many of you as were baptized into Christ have put on Christ. There is neither Jew nor Greek, there is neither slave nor free, there is neither male nor female; for you are all one in Christ Jesus.

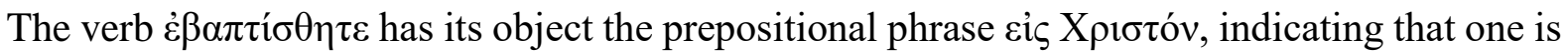
baptised into the realm or sphere of Christ. The preposition $\varepsilon i \varsigma$ has both locative and spherical senses. ${ }^{520}$ Christ is both the final goal of the movement in the baptismal action and the realm

${ }^{520}$ Michael Wolter rejects any spatial sense that might be engendered by the "in Christ" phrase, citing three sets of texts that parallel the New Testament's description of one person's being "in" another; Paul: An Outline of His Theology, trans. Robert L. Brawley (Waco, TX: Baylor University Press, 2015), 238-39. First, he cites examples from the works of Philo of Alexandria (Det. 48; Deus 12; Fug. 61; Fug. 102; Fug. 174) that speak of life in God. Wolter insists that these passages do not show any inkling of the spatial notion of being in God. Rather, it is about a contrast between life in God and life turning away from God. Whilst there is certainly an element of antithesis between life with and without God, one cannot deny the fact that there is an "in God" aspect present in these passages. Wolter has overtly accentuated the antithesis aspect at the expense of the "in God" aspect. Second, Wolter presents so-called Johannine immanence formulae that speak of the believers abiding in Jesus and God and vice versa (John 6:56; 14:20; 15:2, 4-7; 17:21b; John 6:56; 14:20; 15:4, 5; 17:23, 26). He 


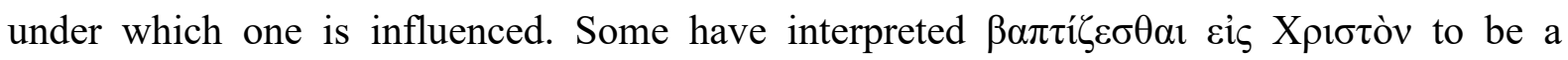

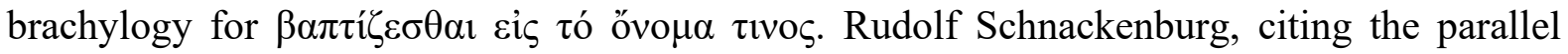

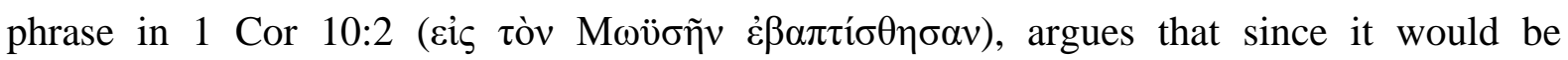
inconceivable to grant $\varepsilon i \zeta$ a local sense in the passage $\beta \alpha \pi \tau i \zeta \varepsilon \sigma \theta \alpha 1$, si $\zeta$ should be linked with

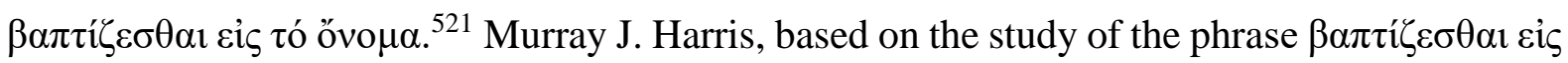

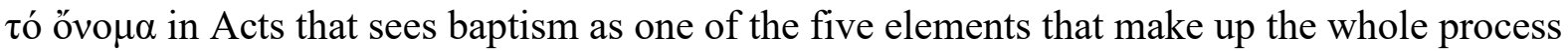

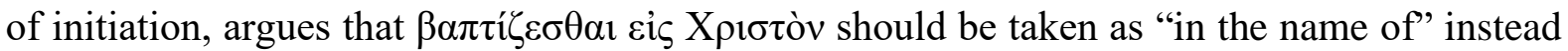
of "into union/fellowship with" Christ. ${ }^{522}$ Whilst one should certainly entertain the possibility

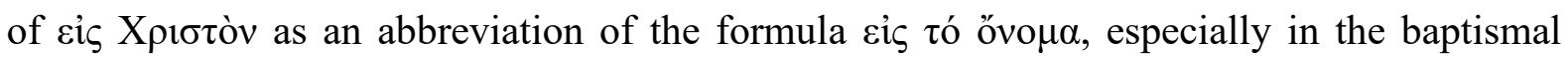
context, both scholars have taken a minimalist approach to interpret the phrase, as it is also pregnant with other meanings such as fellowship with Christ or incorporation into the sonship of Christ, depending on the context. The "in Christ" language engenders several nuances that are contingent on the context in which it appears. Rather than ruling out all possible meanings a priori, one should embrace the possibility of the many meanings that it can contain.

The phrase X

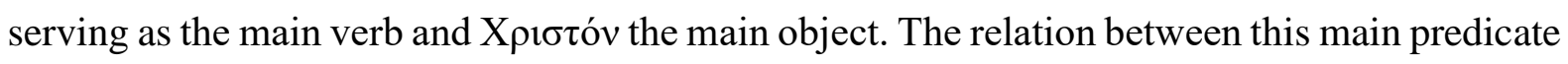
and the prepositional phrase is that the latter signifies the starting movement of entering the mysteries of Christ, whereas the former refers to the union that happens when the movement

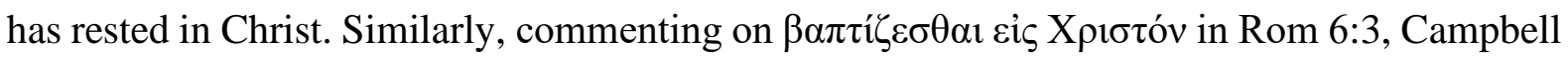
makes a similar observation regarding the movement of baptism:

An "involvement in Christ's death" implies participation - it is dynamic rather than stative, like Paul's

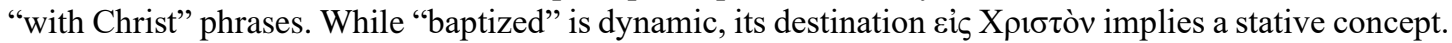
To be baptized into Christ refers to a dynamic action that results in a new state - "identification with Christ.'

\footnotetext{
argues that these "in" statements should be taken as "a belonging that cannot be more closely and more directly conceived." Certainly, the sense of intimacy immediately presents itself from these statements. However, such incomprehensible closeness presupposes that the believers are under the sphere of influence of Jesus and God; otherwise, they would not continue in the state of "abiding." The third set of texts is from Greek literature:

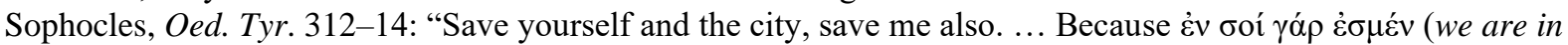
you)," and Euripides, Alc. 275-78: "do not leave me ... you make your children orphans ... if you die, I also do

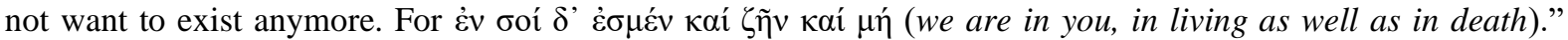
Wolter explains that "in both, it expresses the complete existential dependence on the person 'in' whom one is." Granted, the immediate sense of existential dependence comes to the foreground in these two passages. However, existential dependence in a person necessitates the notion of one's being under the sphere of influence "in whom one is," since the latter exercises some sort of authority over the former's life. Therefore, these three sets of texts do not disprove that the phrase "in Christ" contains a spatial concept; they bolster the argument that it does contain

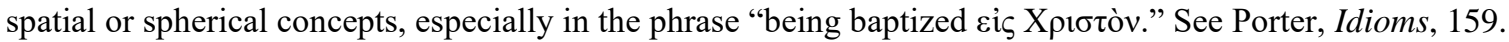

${ }^{521}$ Schnackenburg Baptism, 22-23.

${ }^{522}$ Murray J. Harris, Prepositions and Theology in the Greek New Testament: An Essential Reference Resource for Exegesis (Grand Rapids: Zondervan, 2012), 229.

${ }^{523}$ Campbell, Union with Christ, 149.
} 
Although the "in Christ" phrase in Gal 3:27 has a different nuance than that of Rom 6:2, the same observation regarding the dynamic aspect of baptism, whose ritual action rests in the person of Christ, can be applied to passages that contain baptism and "in Christ" language.

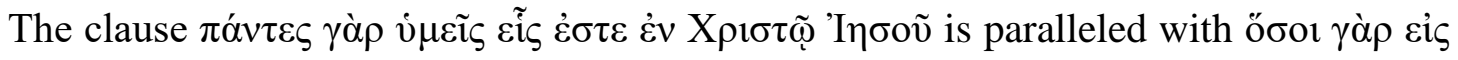

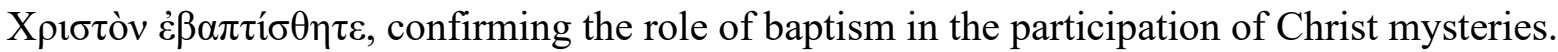

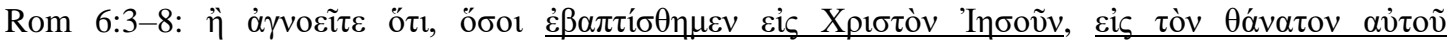

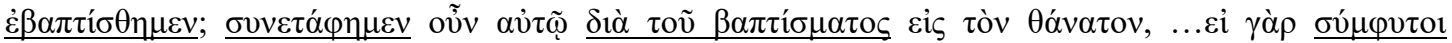

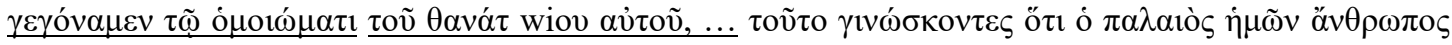

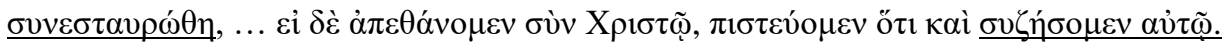

Do you not know that all of us who have been baptized into Christ Jesus were baptized into his death? We were buried therefore with him by baptism into death. ... For if we have been united with him in a death like his, we shall certainly be united with him in a resurrection like his. We know that our old self was crucified with him. ... But if we have died with Christ, we believe that we shall also live with him.

Through a series of parallel structures, Paul illustrates the relationships between baptism and union with and participation in Christ in this passage. On the lexical level, the term baptism in both verb and noun forms ( $\dot{\varepsilon} \beta \alpha \pi \tau i ́ \sigma \theta \eta \mu \varepsilon v, \beta \alpha \pi \tau i ́ \sigma \mu \alpha \tau \sigma \varsigma)$ appears in proximity to various forms

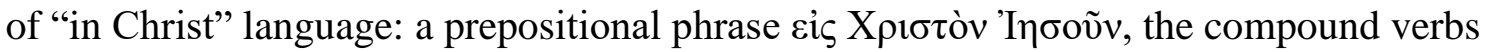

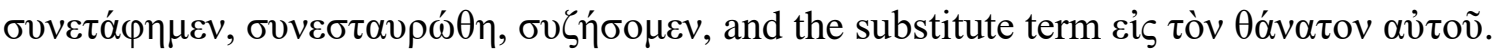

On the sentence level, the parallels are with baptism and the "in Christ" clauses. The first $\dot{\varepsilon} \beta \alpha \pi \tau i \sigma \theta \eta \mu \varepsilon v$ verb appears in the relative clause whose object is the prepositional phrase

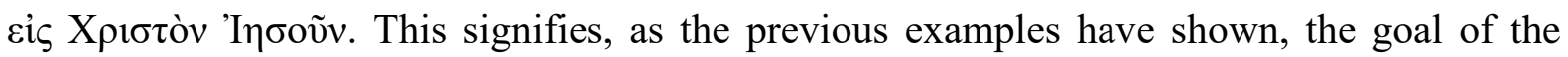
baptismal movement, which is Christ himself. The second $\dot{\beta} \beta \pi \tau i \sigma \theta \eta \mu \varepsilon v$ verb belongs to the subordinate clause that is initiated by the conjunction ö $\tau$ at the beginning of the sentence,

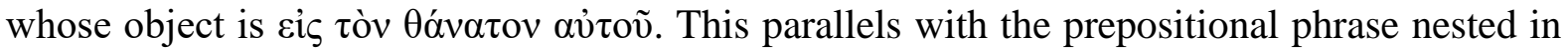
the relative clause. The third time, baptism appears as the noun $\beta \alpha \pi \tau i \sigma \mu \alpha \tau o s$ in the prepositional phrase $\delta i \grave{\alpha} \tau o \tilde{v} \beta \alpha \pi \tau i ́ \sigma \mu \alpha \tau o \varsigma$ that modifies the main verb $\sigma v v \varepsilon \tau \alpha \dot{\varphi} \varphi \eta \mu \varepsilon v$, which

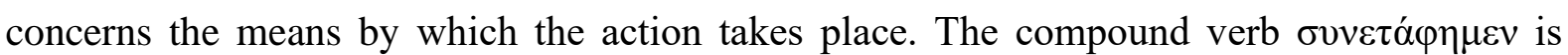
synonymous with the phrase "in Christ" in this passage.

On the structural level, there are also parallels between baptism and the Christ event between clauses: 


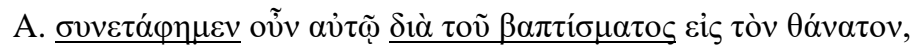

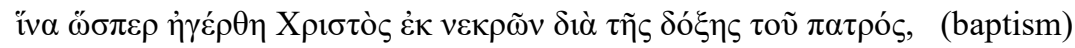

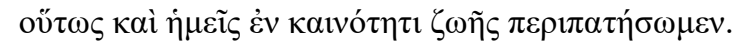

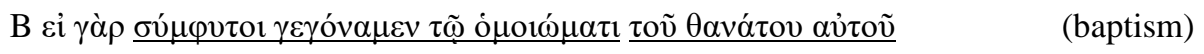

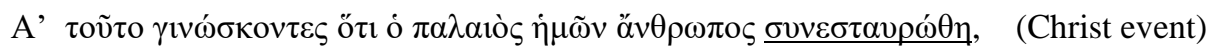

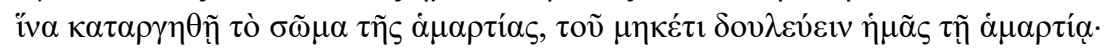

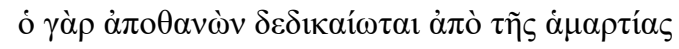

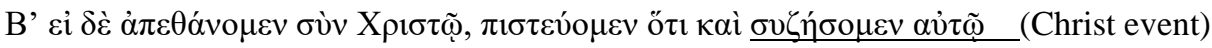

Note that in A and A' the main verbs are $\sigma v v \varepsilon \tau \alpha \dot{\varphi} \varphi \eta \mu \varepsilon v$ and $\sigma v v \varepsilon \sigma \tau \alpha v \rho \omega ́ \theta \eta$, respectively. The former refers to the rite of baptism that initiates the participant's entry to the mysteries of Christ, and the latter invokes the historical death of Christ that is realised through the rite of baptism. Nevertheless, A and A' speak of the same spiritual reality; to wit, being dead to one's old self. Moreover, both contain an epexegetical clause signified by the conjunction iv $\alpha$ that provides further commentary on the main clause: Christ's rising from the dead, which provides the basis for believers to have a new existential living and corresponds with conquering the operation of $\sin$ in one's body.

The B and B' contain first-class conditional sentences that assume the truth from their respective $\mathrm{A}$ and $\mathrm{A}^{\prime}$ premises. The pattern with $\mathrm{A}$ and $\mathrm{A}^{\prime}$ - that the baptism rite corresponds

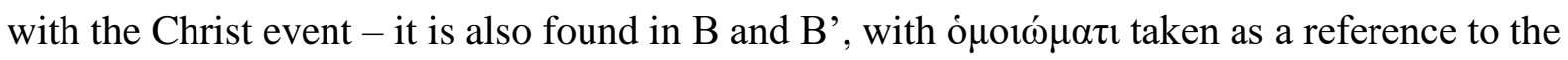
baptismal rite.

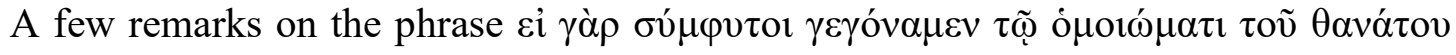

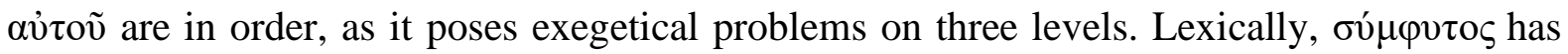
both biological and horticultural connotations: "the growing together of the edges of a wound or fusing of the broken ends of a bone" 524 and "a young branch grafted onto a tree grows together with it in an organic unity and is nourished by its life-giving sap." Thus, it has often been assumed that Paul has the imagery of grafting in mind, supporting the notion of organic unity with Christ. However, the immediate context does not invoke grafting imagery. Grammatically, the issue is whether one should take $\tau \tilde{\varphi}$ o $\mu o t \omega ́ \mu \alpha \tau \iota$ as the dative of respect for

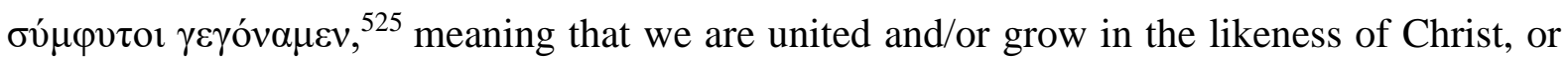
whether one should take it is an instrumental dative, meaning that "we have become united (with Christ) through the likeness of his death," whereby "likeness refers to baptism, and

${ }^{524}$ Dunn, Word Biblical Commentary, 316. Both Dunn and Schnackenburg reject the botanical sense of the word; see Schnackenburg, Baptism in the Thought, 47-49.

${ }^{525}$ See Tannehill, Dying and Rising, 31-39, and Schnackenburg, Baptism in the Thought, 45-47. 


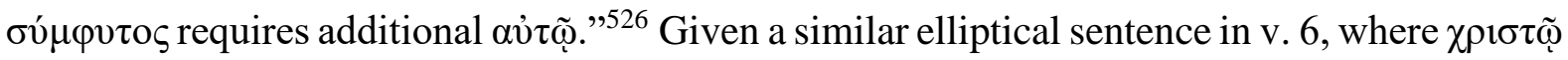

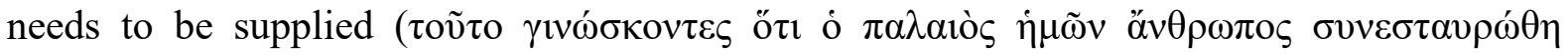
$[\chi \rho ı \tau \tilde{\omega}])$, the supplying of $\alpha$ $\tau \tilde{\omega}$ to $\sigma u ́ \mu \varphi v \tau o$ is justified.

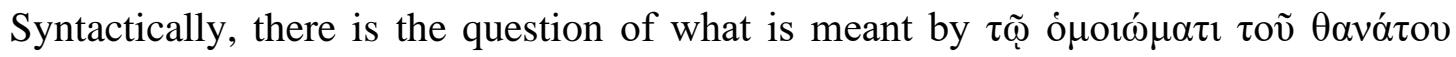

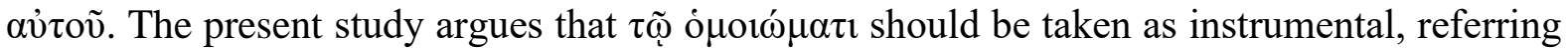
to baptism; that is, one is united (in him) through the likeness (i.e., baptism) of his death for two reasons. Contrary to some scholars, it is possible that o $\mu$ oí $\omega \mu \alpha$ refers to the baptismal rite. Dunn argues that this does not refer to either baptism or Christ's death but to the fusion of the believer into the "reality of Christ's epoch-ending, sin's dominion-breaking-death, in its outworking in the here and now, Christ's death to the extent that it can be experienced and is effective within the still enduring epoch of Adam." ${ }^{, 527}$ Although this interpretation is plausible within the overall context of Paul's argument in Rom 5, the immediate context indicates that Paul is concerned with how believers have been dead to sin through baptism. The conjunction $\gamma \alpha \dot{\rho} \rho$ in v. 5 indicates a conclusion flowing from the arguments in previous verses, while in vv. 3-4 Paul speaks of the relation between baptism and Christ's death. Beasley-Murray contends that $\sigma 0 ́ \mu \varphi v \tau o$, compared to other verbs compounded with $\sigma v v$ in this passage ( $\sigma v v \varepsilon \tau \alpha \dot{\varphi} \varphi \eta \mu \varepsilon v$ and $\sigma 0 v \varepsilon \sigma \tau \alpha \nu \rho \omega ́ \theta \eta)$, denotes the unity between the baptised and Christ himself and that "Paul speaks of our being involved directly with Christ in his death and resurrection through

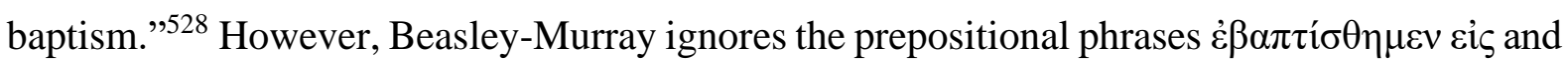

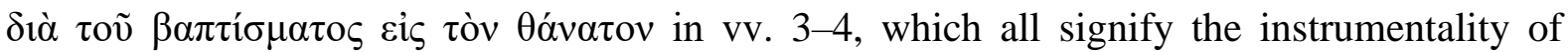
baptism in connection with the union with Christ, meaning that the rite is a medium through which union with Christ is made possible. Schnackenburg, on the basis of his linguistic investigation of the use of ómoí $\mu \alpha$ throughout the Bible, concludes that it denotes something concrete in reference to the death of Christ and that it "should not be interpreted as a cult symbol." ${ }^{529}$ However, the present study dissents from this view and takes ó $\mu$ oí $\omega \mu \alpha$ as an

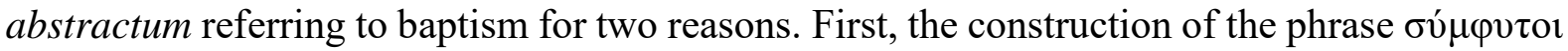

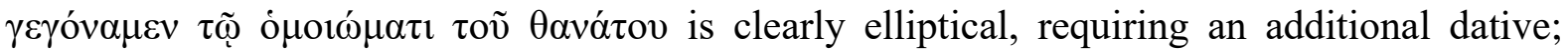
otherwise, the construction is problematic, not least because, for Paul, one is to be united with Christ himself or his body and not with the image of the Christ event. ${ }^{530}$ Second, one might see

${ }^{526}$ See Hans Dieter Betz, "Transferring a Ritual: Paul's Interpretation of Baptism in Romans 6," in Paul in His Hellenistic Context, ed. Troels Engberg-Pedersen (Edinburgh: T\&T Clark, 1994), 115-16.

${ }^{527}$ Dunn, Word Biblical Commentary, 317.

${ }^{528}$ Beasley-Murray, Baptism, 134-35.

${ }^{529}$ Schnackenburg, Baptism in the Thought, 51-53.

${ }^{530}$ See Fitzmyer, Romans, 435. 
ó $\mu$ oí $\omega \mu \alpha$ as a technical term that is "close to the Kultsymbols, the ritual as it makes mythic realities present in symbolic fashion." 531

Structurally, Rom 6:5 serves as a linking point between vv. 2-4, in which Paul describes the baptismal experience that initiands undergo, and vv. 6-11, in which he extends that mystical experience to the personal and ethical dimensions that engender actions of moral living on the

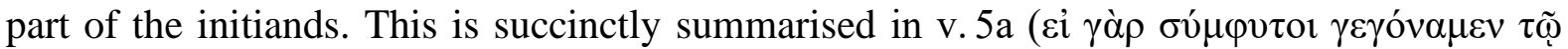

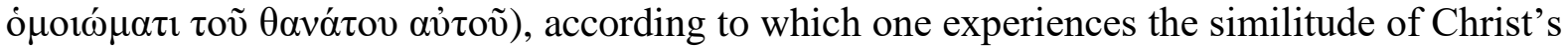

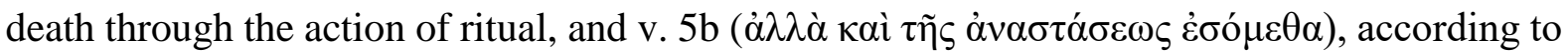
which one experiences the effect of the ritual action that results in a "walking newness of life." Even though the ritual action has been completed, the state of having been mortified at one's old nature remains, as indicated by the perfect tense in v. 5a. The future tense in v. $5 \mathrm{~b}$ signifies that the effects of baptism will fully come to fruition in the general resurrection, where the initiands will experience a bodily resurrection like that of Christ. ${ }^{532}$

Finally, if the first position were to be taken, the question arises: how can one grow together in a likeness? Paul normally describes the believers' union with Christ's body, not with the image of the salvation event. Indeed, Paul speaks of participating in or co-experiencing the Christ event, illustrated by the compound ovv verbs associated with Christ's death and resurrection. However, when Paul denotes the notion of union with Christ, it is always achieved through an instrument, whether the Christ community $(\sigma \tilde{\omega} \mu \alpha)$ or rituals (denoted by the phrases

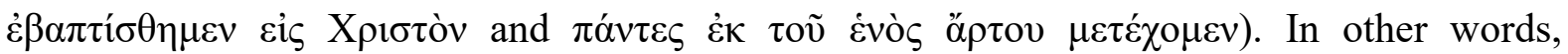
participation is an act of taking part in the Christ event, whereas the union indicates the goal of participation through a certain means of uniting with Christ. Thus, the unwillingness to grant $\tau \tilde{\varphi}$ ó $\mu$ ot $\mu \alpha \tau \imath$ the possibility of being a cultic symbol or ritual bespeaks the problem in the scholarship that tends to intellectualize the experience of union with Christ with a mental grasp of faith, neglecting the physical aspect of that experience, which is realised in the concrete gestures and words of the ritual.

531 See Betz, "Transferring a Ritual," 115-16, and Viktor Warnach, "Taufe und Christusgeschehen nach Römer 6," ALW 3 (1954): 306-07.

532 Contra Dunn, Word Biblical Commentary, 317: "Baptism is hardly like Jesus' death; the perfect tense of v. 5a indicates a continuing state (still under water!?); and the future tense of v. $5 \mathrm{~b}$ points to something other

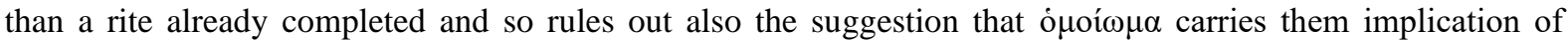
'sacramentally present in baptism.", 


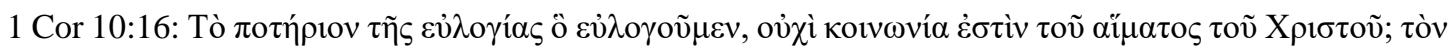

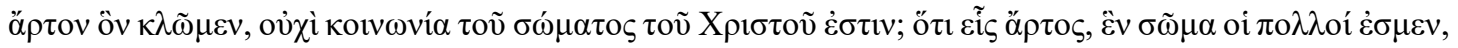

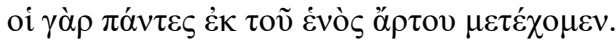

The cup of blessing which we bless, is it not a participation in the blood of Christ? The bread which we break, is it not a participation in the body of Christ? Because there is one bread, we who are many are one body, for we all partake of the one bread.

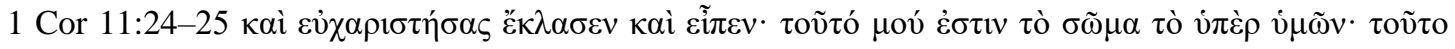

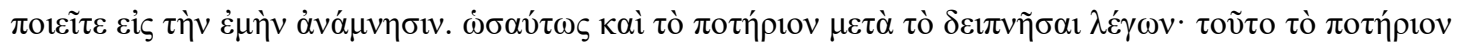

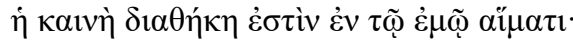

And when he had given thanks, he broke it, and said, "This is my body which is for you. Do this in remembrance of me." In the same way also the cup, after supper, saying, "This cup is the new covenant in my blood."

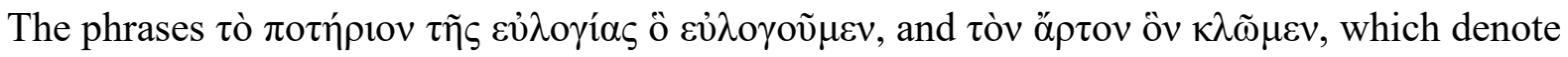
the acts of ritual blessings of bread and wine, relate to the participatory language, as evinced

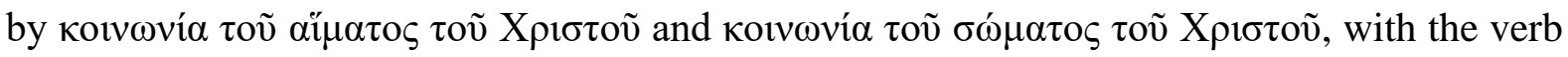

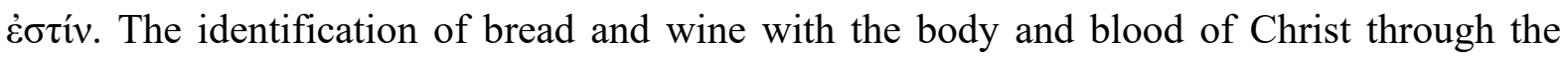

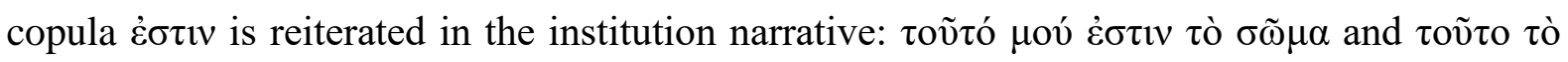

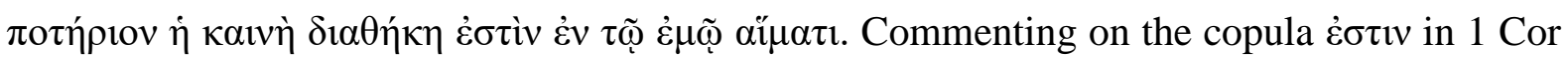

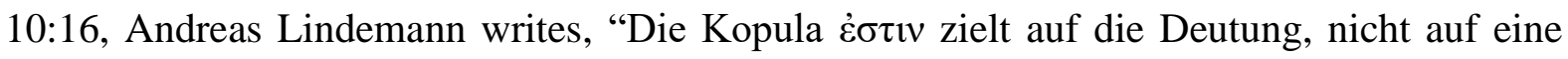
Identitätsaussage; Paulus sagt nicht, dass der Kelch Christi Blut enthält." ${ }^{533}$ Likewise, David Kuske arrives at the same conclusion after having investigated the possible meanings of Korvovía, citing as evidence the fact that Paul does not introduce the element of sharing in the body and blood of Christ in the passage. ${ }^{534}$ However, this conclusion contradicts the following

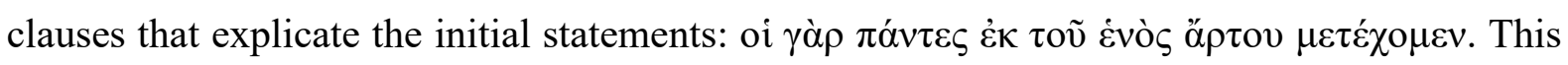

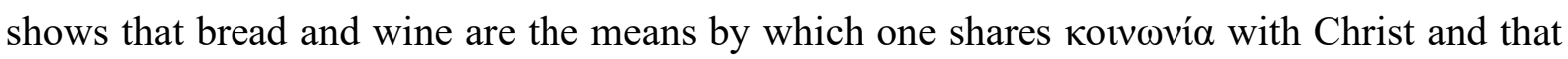
this sharing occurs through partaking elements (i.e., bread and wine). Furthermore, contrary to

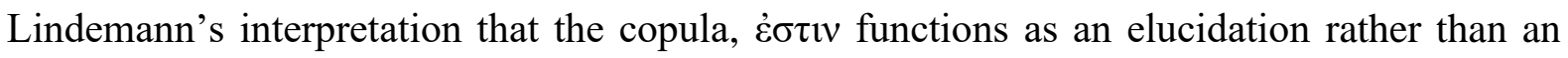
identification; there are examples outside of New Testament literature that show eỉní +

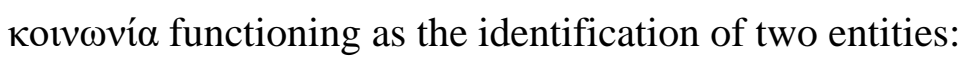

${ }^{533}$ Andreas Lindemann, Der Erste Korintherbrief: Handbuck zum Neuen Testament 9/I (Tübingen: Mohr Siebeck, 2000), 224.

534 David P. Kuske, "Exegetical Brief: Kovvøvía in 1 Corinthians 10:16-Participation or Partnership?" Wisconsin Lutheran Quarterly 101, no. 4 (2004): 284-86. 


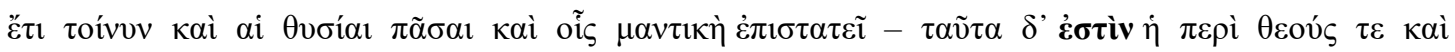

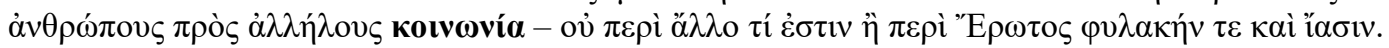

So further, all sacrifices and ceremonies controlled by divination, namely, all means of communion between gods and men, are only concerned with either the preservation or the cure of Love. ${ }^{535}$

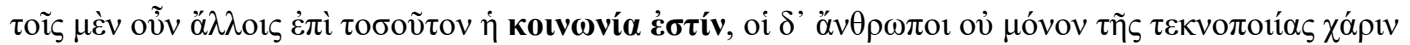

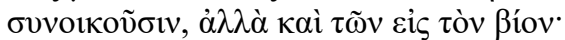

So, whereas with the other animals the association of the sexes aims only at continuing the species, human beings cohabit not only for the sake of begetting children but also to provide the needs of life. ${ }^{536}$

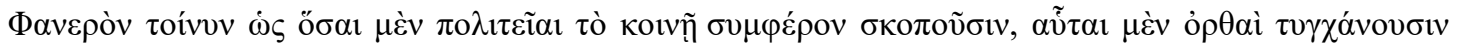

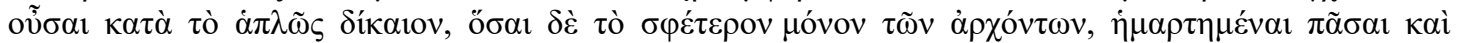

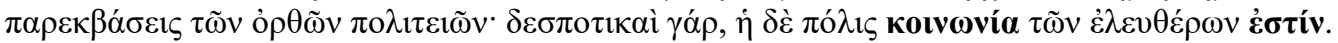

It is clear then that those constitutions that aim at the common advantage are in effect rightly framed in accordance with absolute justice, while those that aim at the rulers' own advantage only are faulty, and are all of them deviations from the right constitutions; for they have an element of despotism, whereas a city is a partnership of free men. 537

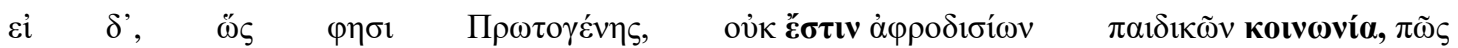

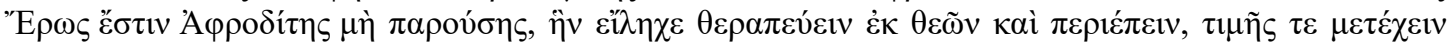

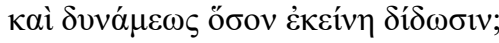

If, on the one hand, as Protogenes maintains, there is no sexual partnership in paederasty, how can there be any Eros without Aphrodite, whom it is his god-given function to serve and wait upon, as well as to receive such portion of honour and power as she bestows? ${ }^{538}$

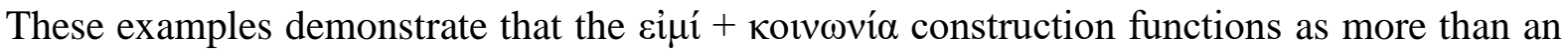

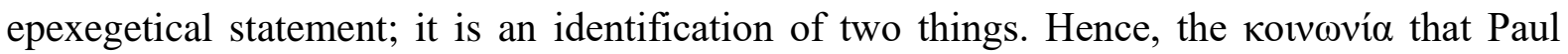
speaks of in 1 Cor 10:16-17 is no less than sharing in the very act of partaking of the elements in the Lord's Supper.

The verb that denotes the dynamic aspect of participation in Christ's mysteries is

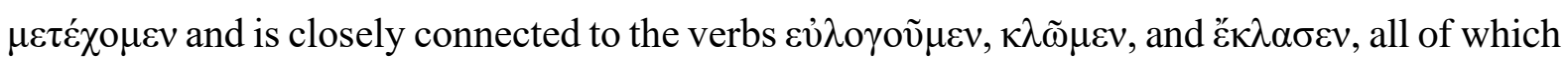
constitute the unified action of participation. The verb that indicates the static aspect of the state of union with Christ is eijú. This can be seen in 1 Cor 10:16, whose relative clauses contain the movement in the direction of entering into the mysteries of Christ (i.e., ô

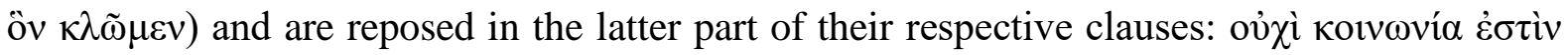

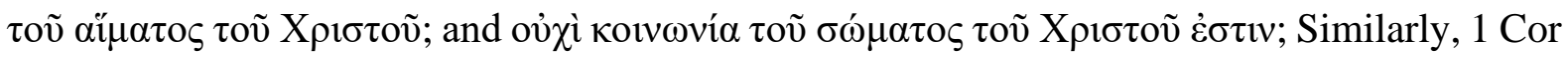
11:24-25 only denotes the static aspect of the union with Christ as it is a formula that recalls the words of Jesus pronounced over the bread and wine on the night he was betrayed.

\footnotetext{
535 Plato, Symp. 188b.

${ }^{536}$ Aristotle, Eth nic. 7, viii, 19.

537 Aristotle, Pol. 1279 a.

${ }^{538}$ Plutarch, Mor. 752B.
} 
Several observations emerge from this syntactical analysis of participatory language with ritual references. First, baptism in verbal form serves in most cases as the verb in the passage in question, with the prepositional phrase $\varepsilon \dot{i} \zeta$ X The exception is Rom 6:4, where baptism in nominal form occurs in the prepositional phrase

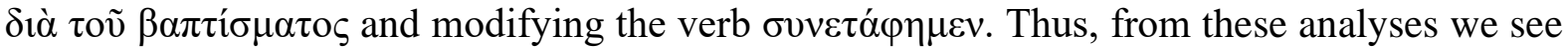
that baptism is a means of salvation in Christ. This finding seems to contradict what J. Thomas Hewitt finds in his recent study on the messianic aspect of "in Christ" language in Paul. ${ }^{539}$ One of the findings of Hewitt's syntactical analysis of that language is that the prepositional phrase "in Christ" accounts for an adverbial use that modifies verbs of divine agency. Hewitt cites 23 instances in which the prepositional phrase indicates Christ as the instrument of God's redemptive plan. ${ }^{540}$ The reason for this discrepancy in our analyses is that Hewitt neglects those passages that have ritual references. ${ }^{541}$ This reflects the common phenomenon in the scholarship, which tends to marginalize the role of baptism and the Lord's Supper in Pauline theology and which we have highlighted above. To reconcile this seeming contradiction, we propose that Hewitt's analysis is correct insofar as redemption through Christ is viewed as a once-and-for-all historical event, whereas salvation in Christ by means of baptism should be the physical actualisation of that historical event brought to the present day. Second, those participatory passages that have the Lord's Supper references indicate that partaking of the meal is to be in union with Christ, as evinced by the eỉut nominal predicate. Finally, based on the first two observations, we can deduce that there are two aspects to participation in Christ dynamic and static, which correspond to baptism and the Lord's Supper, respectively.

\subsection{The Ritual Dimension of Participatory Language}

Having established the close connection between rituals and participatory language in Paul's writings, we are now able to apply the ritual concept to the participatory language, using the ritual transformation model that has been employed in previous chapters. This model has four components: agency, entailment, transformation, and relationality, each of which contributes to the overall process of participating in and union with Christ. Agency initiates the

${ }^{539}$ J. Thomas Hewitt, "In Messiah: Messiah Discourse in Ancient Judaism and 'In Christ' Language in Paul" (Ph.D. diss., University of Edinburgh, 2019).

${ }_{540}$ Hewitt, "In Messiah," 226-33.

${ }^{541}$ It appears that Hewitt deliberately neglects the passages that contain references to baptism in connection with participatory language in his selection of exegetical passages. For example, he selects Gal 3:26

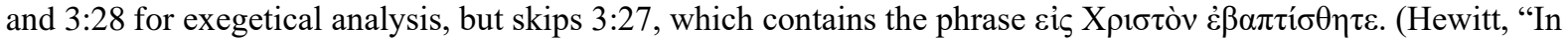
Messiah," 203, 205, 256, 257). Perhaps he considers it to be non-participatory language, as opposed to the words

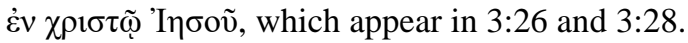


transformation process and is followed by entailment, which is the setting up of the myth that forms the narrative backdrop of the ritual; we continue to the stage of entering the ritual space where the participant undergoes a transformation, resulting in a new reality that has an impact on the wider society.

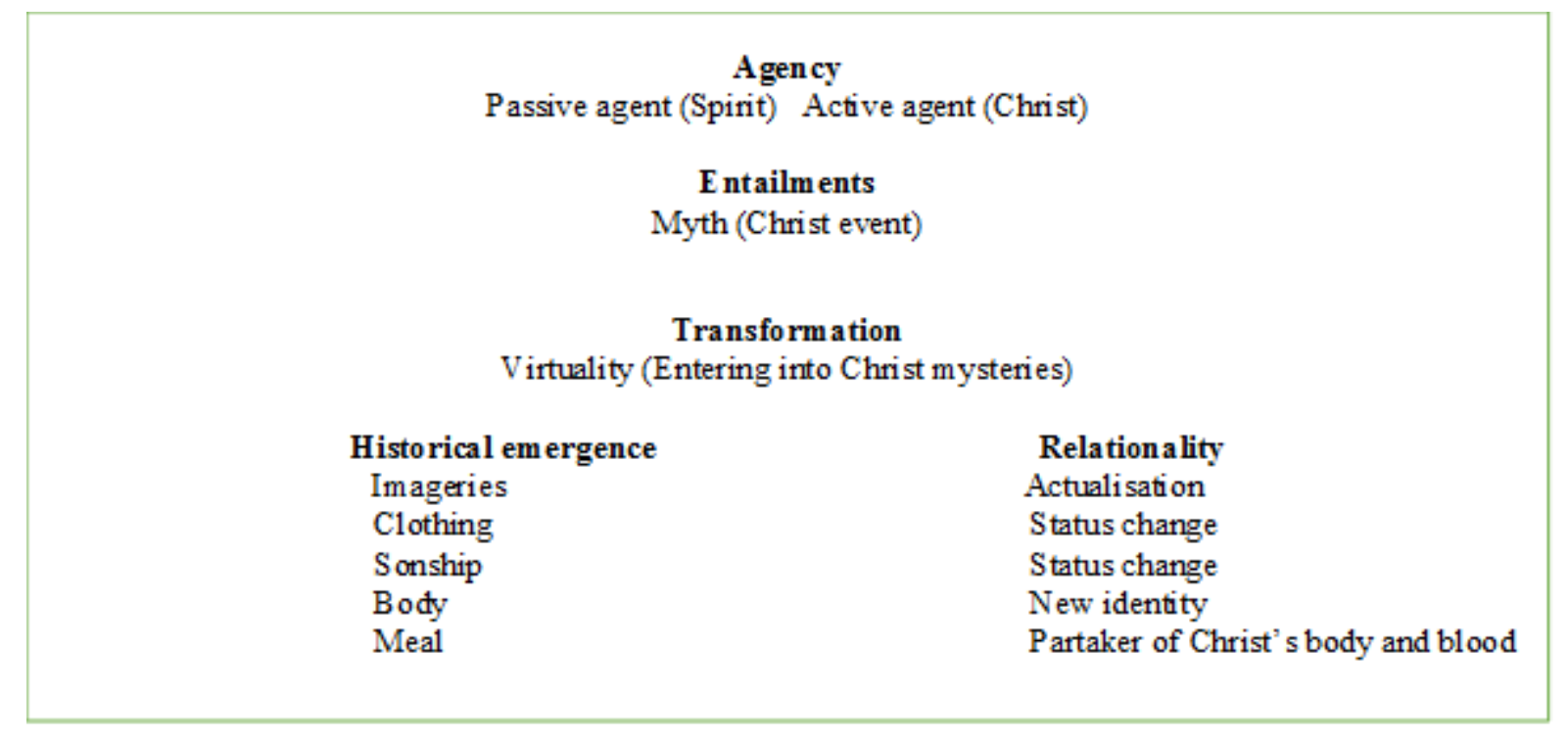

The agency of the baptism ritual is implied in the passive form of the verb $\dot{\varepsilon} \beta \alpha \pi \tau i \sigma \theta \eta \tau \varepsilon$. As 1 Cor 12:13a shows, the passive agent is the Spirit, as illustrated by the phrase $\dot{\varepsilon} v \dot{\varepsilon} v i$ Nonetheless, the verb also has an active form and in all instances it is a human agent who does the baptising (Matt 3:11; Mark 1:8; Luke 3:16; John 1:25, 26, 31, 33; 3:22, 23; 4:1; 10:40; Acts $1: 5 ; 8: 38 ; 11: 16 ; 19: 4 ; 1$ Cor $1: 14,16,17)$ Thus, the spirit is the passive agent in baptism ritual, whereas the human is the active agent in administrating the rite. ${ }^{542}$

The agency of the Lord's Supper ritual is shown through several actions associated with celebrating the rite. In 1 Cor 10:14-16 the various ritual actions are in all in first-person plural form: $\varepsilon \hat{\lambda} \lambda \sigma \gamma o \tilde{u} \mu \varepsilon v, \kappa \lambda \tilde{\omega} \mu \varepsilon v, \mu \varepsilon \tau \varepsilon \dot{\chi} \chi \mu \varepsilon v$, and $\pi i ́ v \varepsilon 1$ while in 1 Cor 11:24-25 these ritual acts are in third-person plural form: $\varepsilon \lambda \alpha \beta \varepsilon v$ and $\varepsilon^{\prime} \kappa \lambda \alpha \sigma \varepsilon v$. Unlike the act of baptism, the acts of celebrating the Lord's Supper are all in the active form, which implies that the divine agent in the ritual takes on a direct role. This can be deduced from the first-person plural form of ritual

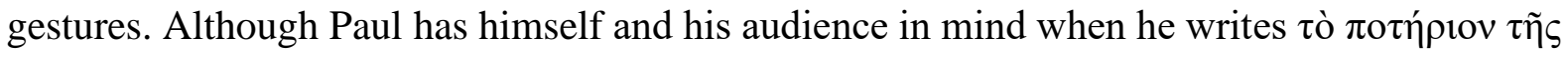

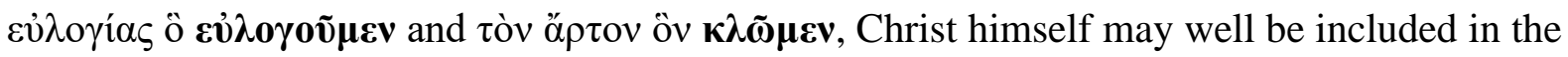

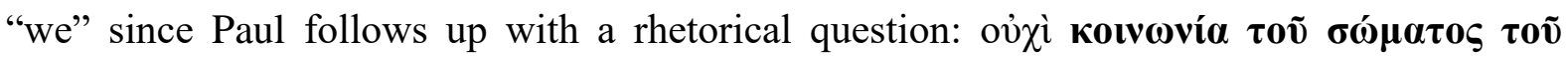

542 James D. G. Dunn notes that in Paul's writings it is God who is described as the one who gives the Spirit (1 Cor 2:12; 2 Cor 1:21-22; 5:5; Gal 3:5; 4:6; 1 Thess 4:8; Eph 1:17); see James D. G. Dunn, The Theology of Paul the Apostle (Grand Rapids: Eerdmans, 1998), 254n105. 


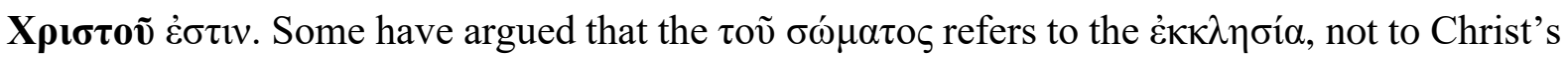

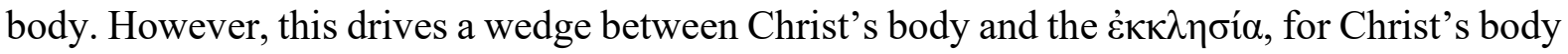

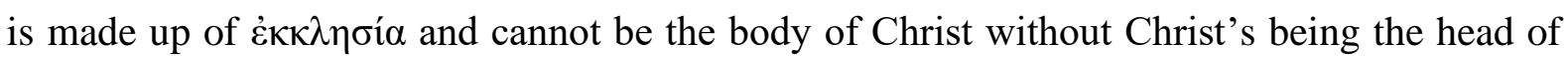
that body (Col 1:18). ${ }^{543} \mathrm{Paul}$ is conscious of this double reference when he employs the term

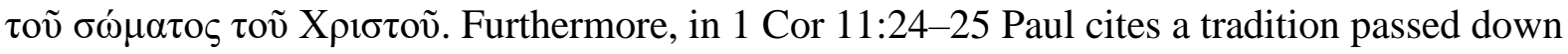
to him that Christ is the main protagonist in the institution narrative, which explains the thirdperson singular verbs. Therefore, the agent in the Lord's Supper includes Christ himself, as an active divine agent, and his followers, who commemorate his death in the same manner as he did on his final night.

The linguistic markers that intimate the entailment of myth in baptism and the Lord's

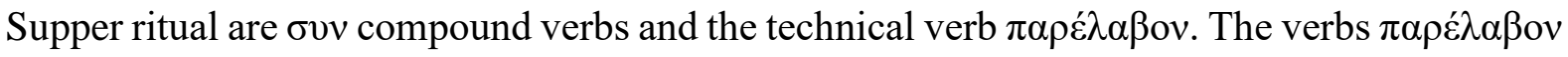
and $\pi \alpha \rho \varepsilon ́ \delta \omega \kappa \alpha$ in 1 Cor 11:23 are a technical language of imparting knowledge or tradition and a linguistic clue that shows the entailment of myth in the Lord's Supper ritual. In both the Greco-Roman and Jewish worlds, these terms are employed for the cultivation of knowledge and imparting of tradition (Plat., Phileb. 16c; Ep. 12.359d; Diod. S., Bibl. His. 12.13.2; Wis 14:15; Jos., Ap. 1.60; cf. Mark 7:13; Gal 1:14). Although Paul employs both terms on several occasions to impart the traditions that have been handed down to him (1 Cor 15:3; 1 Thess 2:13; 4:1; Gal 1:9, 12; Phil 4:9), it is only in 1 Cor 11:23 that both terms appear in the ritual context. The idea that the ritual is a proper setting in which the existential knowledge of the universe and humanity is passed down to the initiates is common to many ancient mystery cults (Diod S., Bibl. Hist. 5.49.5).

The preposition ovv has two basic usages in the New Testament, namely, association and accompaniment. Regarding the use of $\sigma 0 v$ with the theme of union with Christ, scholars have observed that Paul consistently employs бúv over $\mu \varepsilon \tau$ ó to form the idiom "with Christ," leading to the conclusion that the former denotes intimate relations and thus union, whereas the latter refers to attendant circumstances or associations. The three ovv compounds in Rom

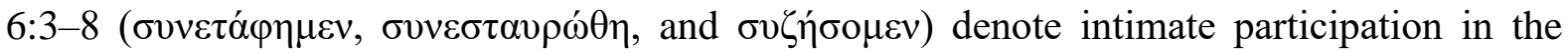
Christ event, of re-living the death, burial, and resurrection of Christ. Each of these $\sigma v v$ compounds is encoded with an aspect of the Christ myth that narrates a redemptive history. The compound $\sigma v v \varepsilon \sigma \tau \alpha u \rho \omega ́ \theta \eta$ invokes the Passion of Christ; by extension, his followers are invited to experience suffering with him (Rom 8:17; 2 Cor 1:7; Phil 1:29; 3:10; 2 Tim 2:12; Cf.

543 "For if Christ could not be fully conceptualized apart from talk of Christ's body, so participation in Christ could not be adequately conceived independently of the body made up of many members." Dunn, Theology of Paul, 411. 


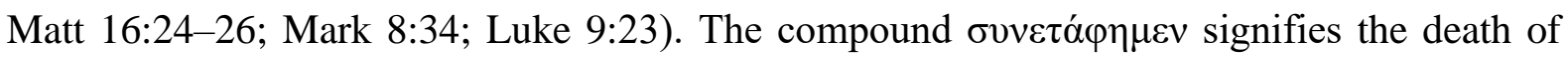
Christ, in which the believers are called on to participate, a lifelong process of being dead to

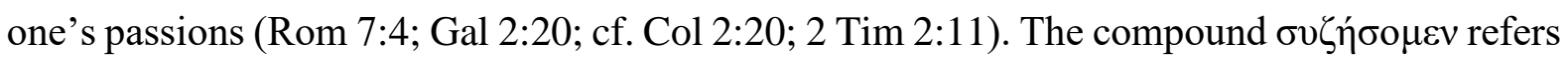
to Christ's resurrection and his newness of life, in which the believers are asked to live in a form of resurrection; that is, living without being subjugated to the dominion of $\sin (2$ Cor 13:4b), and in expectation of a future resurrection ( 2 Cor 4:14; 1 Thess $4: 14 ; 5: 10$; Col 3:4).

Since ouv compound verbs denote a close association with Christ, some have argued that it is with these Christ events that one is in union. This observation is partially true. Given the immediate context, Paul speaks of being united with Christ's triumph over sin and death just as believers should become victors over their own sinful passions in the body (Rom 5-6). Nevertheless, uniting with the Christ event presupposes a union with the person of Christ in the first place. ${ }^{544}$ Paul demonstrates this logical sequence by first mentioning the general term

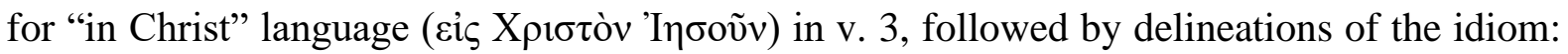

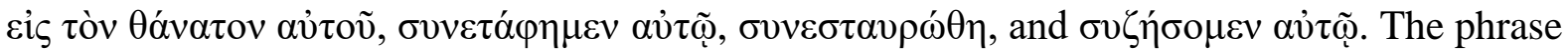

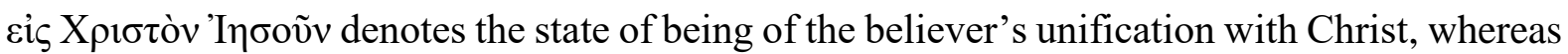
the derivatives of "in Christ" language that follow have the dynamic of participating in Christ's redemptive history.

The term $\sigma v v$ appearing as a technical term in the ritual context is also attested outside the Christ religion. James Hope Moulton, in Vocabulary of the Greek Testament, cites two passages from a magic ritual that employ the preposition $\sigma v v$ to denote the notion of "in fellowship with":

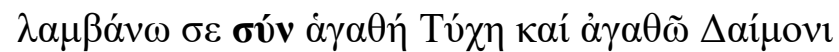

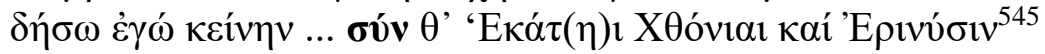

Granted, one may dismiss any similarities between rituals in the Christ religion and those of its pagan counterparts, given that recent scholarship has demonstrated that the two developed independently of each other. However, since both are part of the wider Mediterranean cultural terrain, it is inevitable that they share the common stock of religious language, motif, and metaphor to articulate the salvation of the initiates. For instance, the notion of a "suffering god" appears in both mystery cults and the Christ religion and is enacted in the ritual. In mystery

544 This earlier union is made possible through faith and ritual; for more on the relationship between faith and ritual, see chapter 5 below.

${ }^{545}$ Bold mine. James Hope Moulton, Vocabulary of the Greek Testament Illustrated from the Papyri and Other Non-Literary Sources (London: Hodder \& Stoughton, 1901), 600. 
cults, the initiates model their fate on that of suffering gods in the ceremonies and rites, accompanied by grief and mourning in a nocturnal setting: ${ }^{.56}$

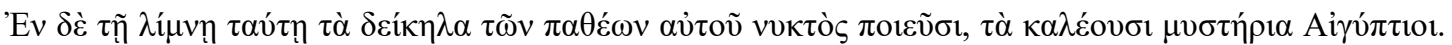

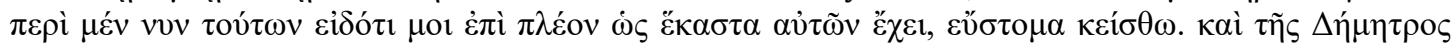

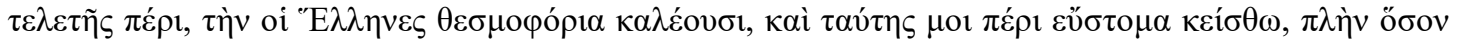

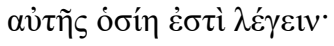

On this lake they enact by night the story of the god's sufferings, a rite which the Egyptians call the Mysteries. I could speak more exactly of these matters, for I know the truth, but I will hold my peace; nor will I say aught concerning that rite of Demeter which the Greeks call Thesmophoria, saving such part of it as I am not forbidden to mention. ${ }^{547}$

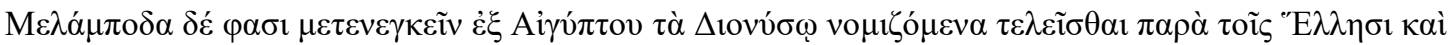

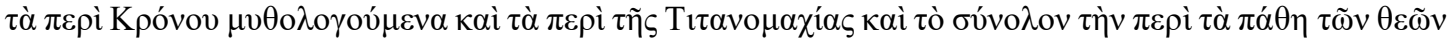

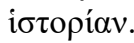

Melampus also, they say, brought from Egypt the rites which the Greeks celebrate in the name of Dionysus, the myths about Cronus and the War with the Titans, and, in a word, the account of the things which happened to the gods. ${ }^{548}$

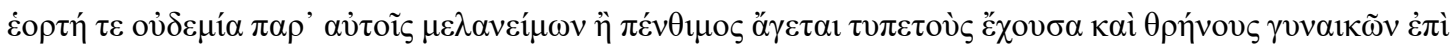

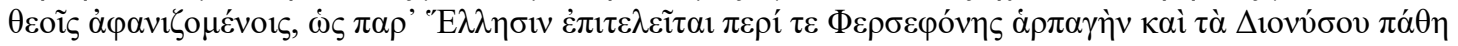

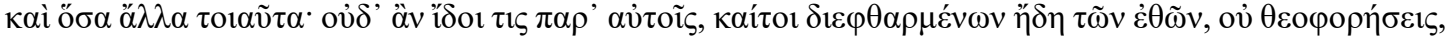

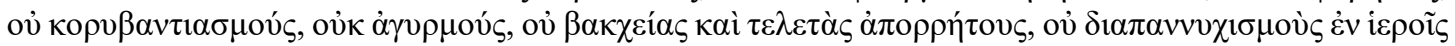

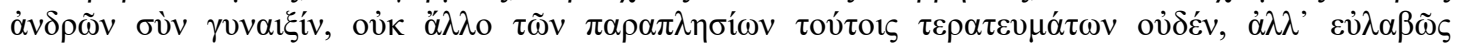

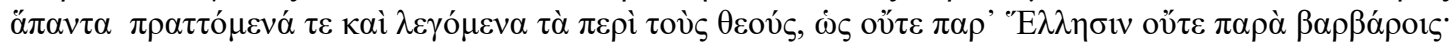

And no festival is observed among them as a day of mourning or by the wearing of black garments and the beating of breasts and the lamentations of women because of the disappearance of deities, such as the Greeks perform in commemorating the rape of Persephonê and the adventures of Dionysus and all the other things of like nature. And one will see among them, even though their manners are now corrupted, no ecstatic transports, no Corybantic frenzies, no begging under the colour of religion, no bacchanals or secret mysteries, no all-night vigils of men and women together in the temples, nor any other mummery of this kind; but alike in all their words and actions with respect to the gods a reverence is shown such as is seen among neither Greeks nor barbarians. ${ }^{549}$

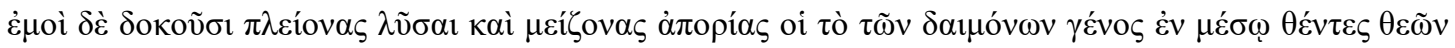

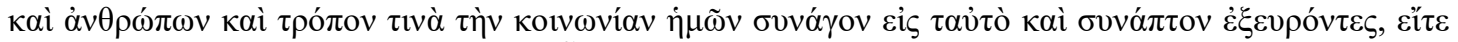

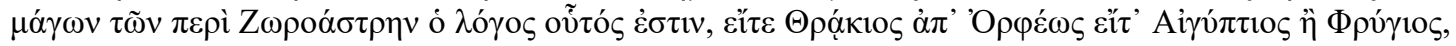

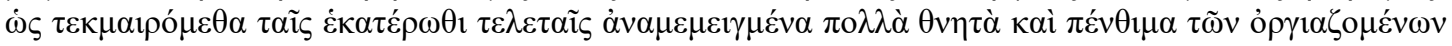

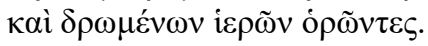

But, as it seems to me, those persons have resolved more and greater perplexities who have set the race of demigods midway between gods and men, and have discovered a force to draw together, in a way, and to unite our common fellowship - whether this doctrine comes from the wise men of the cult of Zoroaster, or whether it is Thracian and harks back to Orpheus, or is Egyptian, or Phrygian, as we may infer from observing that many things connected with death and mourning in the rites of both lands are combined in the ceremonies so fervently celebrated there. ${ }^{550}$

\footnotetext{
${ }^{546}$ Walter Burkert, Ancient Mystery Cult (Cambridge: Harvard University Press, 1987), 75.

${ }^{547}$ Herodotus, Hist. 2.171.

${ }^{548}$ Diodorus Siculus, Library of History 1.97.4.

${ }^{549}$ Dionysius, Ant. rom. 2.19.

${ }^{550}$ Plutarch, Mor. 415a
} 
Three observations can be offered. First, the linguistic clues for the entailment of myth in these rituals of mystery religion are the enactment of the story of god's suffering ( $\tau \dot{\alpha} \delta \varepsilon i ́ \kappa \eta \lambda \alpha \tau \tilde{\omega} v$

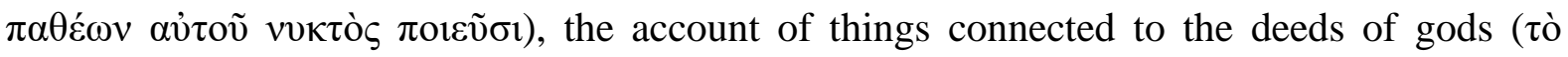

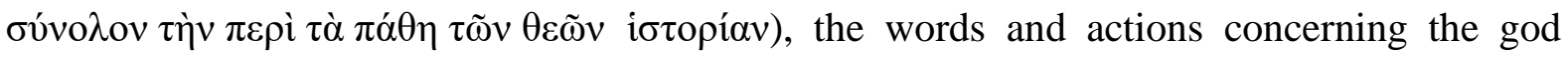

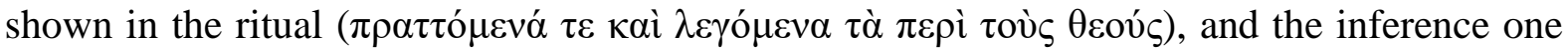
can make from observing the ritual actions the deeds of the gods ( $\tau \varepsilon \kappa \mu \alpha \iota \rho$ ó $\mu \varepsilon \theta \alpha)$. Second, the myth narrative is wedded to the rituals that re-enact the story of a suffering god through words and actions. Finally, there is an overall melancholy atmosphere that pervades these rituals commemorating the suffering of the gods, intimated by the practice of mourning and wearing of a black garment, as opposed to a triumphal spirit that permeates the baptismal ritual that not only recounts the suffering and death of Christ, but also celebrates the entry into a new life through death. Similarly, in the baptism ritual, the participants re-enact and commemorate the passion and death of Christ in the movement of immersion into the water. Although there are greater dissimilarities than similarities in mystery cult and Christ religion rituals, both have the ritual element of entailment of the myth of a suffering god whose fate is modelled for and participated in by initiates so that they may share in the same salvific events.

Now, having initiated the ritual action by divine and human agents and set up the ritual scene of the Christ myth, the participants are ready to enter the heart of Christ's mysteries,

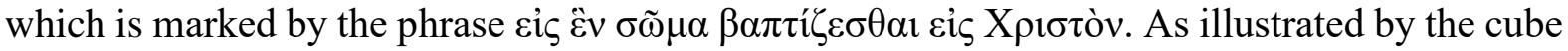
diagram in Stanley E. Porter's Idioms of the Greek New Testament, the preposition cis with the accusative case "concern[s] with movement of the sphere toward and into the cube, as if this were the action that resulted in the condition of $\dot{\varepsilon} v^{.}{ }^{\prime 551}$ The preposition $\varepsilon i \zeta$ with the accusative case appearing in 1 Cor 12:15, Gal 3:26-27, and Rom 6:3-8 indicates a movement into a sphere

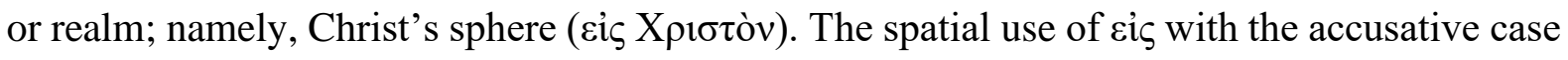
is attested by the following passages from Greek literature:

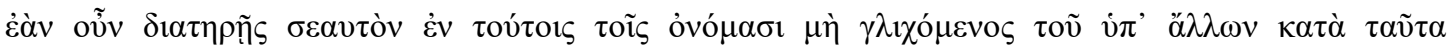

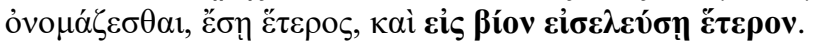

Only keep thyself entitled to these appellations, not itching to receive them from others, and thou wilt be a new man and enter on a new life. ${ }^{552}$

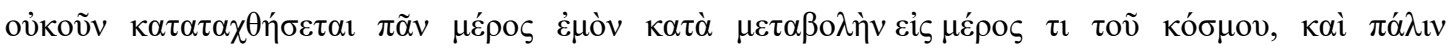

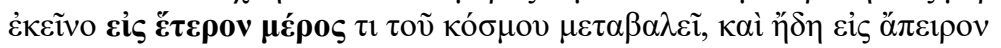

\footnotetext{
551 Porter Idioms, 151.

${ }_{552}$ Marcus Aurelius, Med. X 1-2.
} 
So shall my every part by change be told off to form some part of the Universe, and that again be changed into another part of it, and so on to infinity. ${ }^{553}$

Note that $\varepsilon i \zeta$ in these passages intimates entering a place or realm. The first passage speaks of a person entering a state of being, and the second of body parts transformed from an existing status to a new one. In these two examples, the preposition eic indicates a movement of a sphere entering a place or realm, or a state of being, or a status. Thus, the phrase $\varepsilon i \zeta \ldots \beta \alpha \pi \tau i \zeta \varepsilon \sigma \theta \alpha 1$

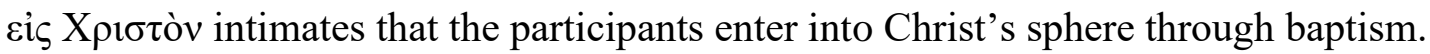

Just as the baptism ritual indicates the movement of entering the ritual space, the Lord's Supper denotes the result of that action, the condition of being in Christ, which is indicated by

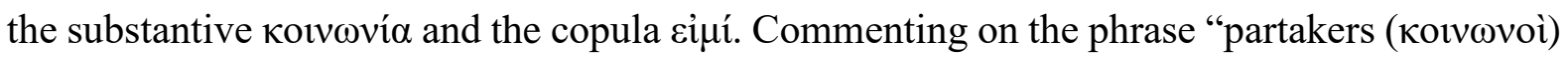
of the divine nature" in 2 Peter 1:4, Nigel Turner explicates the static aspect of the union with Christ:

\begin{abstract}
Designedly, he chose substantives rather than verbs or adjectives to describe Christ's relationship with those who are en Christo, and delicately turned away from activity to existence, his idiom subconsciously following his theology. What was once activity and growth and movement has now become identification. Verb and adjective cease to be appropriate, supplanted by the substantive idiom. ... The unusual and unidiomatic parade of substantives is consistent with St. Paul's doctrine of the union and indwelling of the believer. Identification renders activity and attribution redundant, for they would represent a relationship between separate entities. Christ and the believer, like Christ and the Father, are one - a substantive whole/Predication alone is feasible and a new idiom is demanded where "Christification" has taken place - the predication of an abstract noun to a personal name..$^{554}$
\end{abstract}

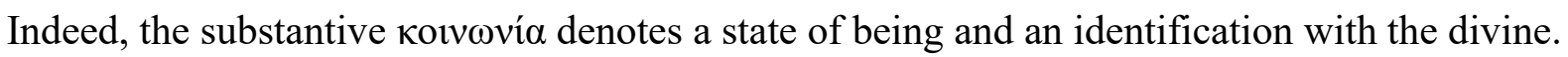
This status of union is achieved by partaking of the Lord's Supper through which the participants identify themselves with Christ. In the process of identification with Christ afforded by the Lord's Supper, the participants encounter divine forces in the formation of their new identity in Christ, which derives from the union between the Father and the Son as Jesus speaks of oneness between himself and the Father (John 10:30). The copula cíní designates the intimate relationship between the two, and Jesus invites his followers to partake of this oneness

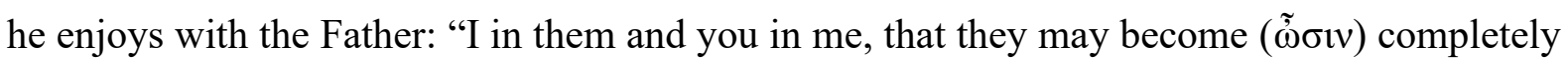
one, so that the world may know that you have sent me and have loved them even as you have loved me" (John 17:23; cf. John 17:10-11, 21, 26). The concrete way this oneness is realised is in the celebration of the Lord's Supper in which the oneness is manifested in the sharing of

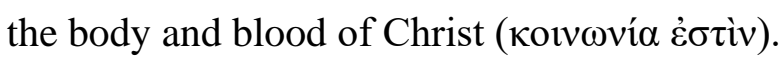

${ }^{553}$ Marcus Aurelius, Med. V.

${ }^{554}$ Nigel Turner, Grammatical Insights into the New Testament (Bloomsbury Academic Collections; London: Bloomsbury, 2015), 118-21. 
The result of this ritual transformation is called historical emergence or the desired results of ritual performance. The success of a ritual performance hinges on the successful implementation of ritual symbols in the performance, whose process is subject to the contingencies of the historical and social circumstances in which the ritual is performed. ${ }^{555} \mathrm{In}$ the case of baptism and the Lord's Supper rituals, there are a total of four ritual symbols implemented in the performance of these rites: clothing, sonship, body, and meal. Clothing, sonship, and body are deployed in the baptism ritual, and the symbols of body and meal are employed in the Lord's Supper. Although we do not have full access to the record of these rituals in the New Testament, the success of the rite can be deduced from the Paul's statements in his letters to various Christ communities. These statements are Paul's exhortations to his readers to live up to the new status obtained through these rituals:

\section{Clothing}

Instead, put ( $\dot{\varepsilon} v \delta v \dot{\sigma} \sigma \sigma \theta \varepsilon)$ on the Lord Jesus Christ, and make no provision for the flesh, to gratify its desires. (Rom 13:14; cf. Ep 4:24; Col 3:10)

\section{Sonship}

For all who are led by the Spirit of God are children of God (vioì $\theta \varepsilon$ ov) (Rom 8:4)

And because you are children (vioí), God has sent the Spirit of his Son into our hearts, crying, "Abba! Father!" So you are no longer a slave but a child, and if a child then also an heir, through God. (Gal 4:6-7)

\section{Body}

So we, who are many, are one body ( $\sigma \tilde{\omega} \mu \alpha ́)$ in Christ, and individually we are members one of another. (Rom 12:5)

\section{Meal}

When you come together, it is not really to eat the Lord's Supper (кvрrakòv $\delta \varepsilon \tilde{\pi} \pi \nu v)$. For when the time comes to eat, each of you goes ahead with your own supper ('ioıv $\delta \varepsilon i \tilde{\tau} v 0 v)$, and one goes hungry and another becomes drunk. (1 Cor 11:2021)

Note that in these parenesis statements, Paul applies the very imagery from baptism and the Lord's Supper to the ethical life of a Christ follower. This may suggest that these images first originated in the ritual setting of the Christ religion, whose ramifications for a new life after

555 Schieffelin, “On Failure and Performance,” 61, 66-67. 
the ritual performance are drawn. ${ }^{556}$ From these statements of Paul, one can deduce that the ritual emergence fails to materialise (due to the failure in the synergetic corporation between divine and human) in some individuals and communities. To maintain the effects of ritual performance, individuals need to be reminded of their newly gained status in ritual performance and to strive to practice the principles that are embodied in these ritual symbols: 1) put on the personality of Christ who is alien to sins (clothing), 2) be guided by the Spirit who grants freedom from sins to those who do not succumb to the operation of the passions (sonship), 3) be united in the same mind and the same purpose amongst the Christ's body (body), and 4) demonstrate Christ-like sacrificial love on the table of the Lord (meal). For those who embody these principles in their lives, ritual emergence has been realised from the ritual performance.

Finally, the emergence from ritual performance results in a new kind of relationship amongst the participants and the divine being. There are three levels to these newly configured relationships: the self, fellow participants, and the divine being.

The relation to the self is a then-and-now schema (which reflects conversion) that emphasises a definitive break from past existence to the new one in Christ:

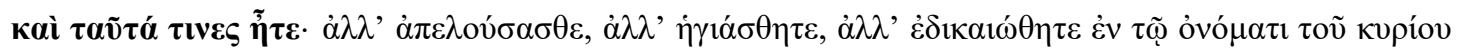

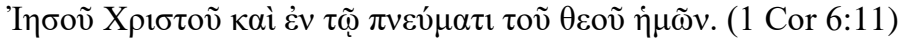

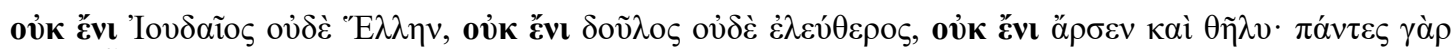

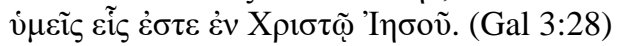

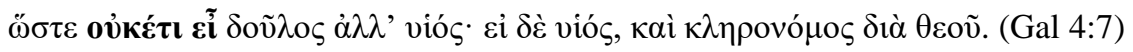

In these passages, Paul highlights the stark contrast between life then and now by negating the copula $\dot{\varepsilon} \sigma \tau \imath v$ that identifies his readers with their former way of life. Both 1 Cor 6:11 and Gal 3:28 emphasise this permanent break from the old existence in triadic form: $\dot{\alpha} \lambda \lambda{ }^{\prime} \ldots \dot{\alpha} \lambda \lambda{ }^{\prime} \ldots$

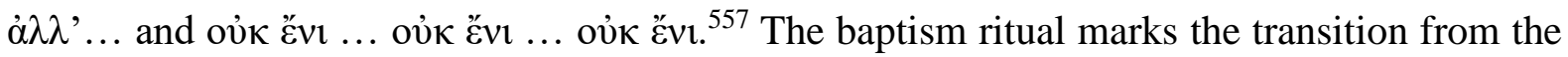
old existence to the new.

${ }^{556}$ Commenting on the relation of baptism to the theme of union with Christ in Rom 6:1-11, Romano Penna observes that baptism is a subsidiary topic in the pericope, given that the event of Christ's death pre-exists the rite, whose meaning is given by the "autonomous reality," i.e., the Christ event; see Paul the Apostle: Jew and Greek Alike: A Theological and Exegetical Study, Volume 1, trans. Thomas P. Wahl (Collegeville, MN: The Liturgical Press, 1996), 131-32. This view is, however, too simplistic. There are likely two-way streets between the objective Christ event and the rites and ceremonies. The former serves as the theological ground in which the latter are built while the latter reinforce and deepen the theological understanding of the Christ event that is reenacted in the rites and ceremonies.

${ }^{557}$ Most commentators define हैंv to mean "there is," "to exist," or "to be in": see Herbert Weir Smyth, Greek Grammar (Cambridge: Harvard University Press, 1920), §175b; Franco Montanari, The Brill Dictionary of Ancient Greek (Leiden: Brill, 2015), 692; and Longenecker, Galatians, 156. For an alternative view, see J. B. Lightfoot, St. Paul's Epistle to the Galatians: A Revised Text, rev. ed. (London: Macmillan, 1865), 150. 
A new relation formed amongst the initiates realises itself in the ritual symbols of $\sigma \tilde{\omega} \mu \alpha \dot{~}$ and $\delta \varepsilon \tilde{i} \pi v o v$. Through baptism and partaking of the Lord's Supper, the initiates are incorporated into a new society: the body of Christ. Each of the individuals who make up the members of Christ's body has his or her own function to perform for the edification of the whole body, and each individual is sustained by the same loaf and drink that are Christ's body and blood. Baptism incorporates the initiates into Christ's body, and the Lord's Supper cements this newfound identity and status. 558

The relation between the initiates and God actualises itself in all four ritual symbols, each with a different nuance. The clothing symbol signifies that the initiates have received righteous status before God. Like the first human progenitors who were been stripped naked of their glory after they sinned and needed garments to cover their nakedness, the initiates have been clothed with a new garment of glory and have boldness before God because their nakedness is covered. The sonship symbol designates a whole new relationship between God and humanity, that the latter, once estranged from God by the Law and sin, can now be adopted as children of God through Christ. The body symbol shows that the initiates can now have intimate relations with God by becoming a member of Christ's body, a living organism whose head is Christ. The meal symbol reveals that the initiates can have the most intimate relations with God as husband and wife, as depicted by the image of the marriage feast of the Lamb (

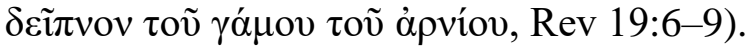

\subsection{Conclusion}

The study of participatory language from the ritual perspective has yielded certain important observations. First, using ritual categories to explicate the participatory language has bridged the gap between the mystical approach and the realistic or historical approach, since ritual as a technology creates a virtual space for re-creation, re-production, and re-configuration within the concrete circumstances of personal social and historical realities. ${ }^{559}$ In other words, ritual bridges the gap between cerebral modes of participation in various abstract categories (i.e., Christ event, the Spirit, and corporate identity) and that of a mystical and existential mode of

${ }^{558}$ Ridderbos, Paul: An Outline, 424-25: "As such the unity of the church as the body of Christ attaches to both, baptism as entrance to and incorporation into the body, the Supper as the unity and the body repeatedly received and manifested afresh in eating one bread. Implicit in this are the distinct functions baptism and the Lord's Supper have as means of salvation, likewise with respect to the body of Christ. Baptism incorporates, represents the transition from "dead to sin" to "alive to God" (Rom. 6:11). ... The Supper is the continuing proclamation of the redemptive significance of Christ's death; it is spiritual food and spiritual drink for the time between times."

${ }^{559}$ Kapferer, "Virtuality," 672. 
participation. Second, the syntactical analysis of passages that contain references to both ritual and participatory language demonstrates the inextricable connection between the two: either

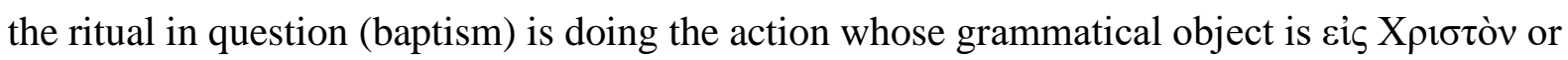
the ritual in question (the Lord's Supper) is identified with the participatory language predicate through a copula verb. Third, using the ritual transformation model allows the entire process of participation in Christ to be delineated, to an extent, in a general way from the beginning of ritual action (agency) to the climax of ritual transformation (entailment and virtuality), resulting in ritual emergence and a transfigured relationship. 


\section{Chapter 5 \\ Pistis and Ritual: Their Roles and Relationship}

\subsection{Introduction}

The relationship between pistis ${ }^{560}$ and ritual is often presented in the theological debate between pistis and baptism: does pistis save ${ }^{561}$ a person or does baptism $?^{562}$ Naturally, one's answer to the question aligns with one's theological persuasion. Those with Protestant inclinations would argue that it is pistis that saves a person, not baptism, which is thus understood as a symbol or mere metaphor. ${ }^{563}$ By contrast, those with Catholic or sacramental inclinations would defend the efficacy of baptism and the other sacraments in salvation in Christ. ${ }^{564}$ The debate often tends towards two opposing poles, the dichotomy between pistis and baptism (or sacraments in general). To overcome this impasse, the present study proposes that a re-examination of the terms pistis and sacraments is sorely needed. Often, the definition of pistis is not clearly defined in scholarly discourse. Either it is assumed with the meaning of belief or one's response to the gospel, or it is given a partisan definition that neglects its other aspects. The definition of sacrament, on the other hand, is a theologically loaded term whose meaning has been defined differently by different traditions over the centuries. For a fruitful inquiry into the relationship pistis and baptism (or sacraments in general), the present study places both terms on a level playing field by expanding the definitions of pistis and by considering sacrament as ritual in the anthropological sense. ${ }^{565}$ This chapter holds that pistis

${ }^{560}$ Given the translation issues over pistis (faith/faithfulness), this study uses pistis consistently, with rare exceptions explained. For the historical development of the term pistis, see Dennis R. Lindsay, "The Roots and Development of the $\pi \imath \tau$ - Word Group as Faith Terminology," JSNT 15, no. 49, (1993) 103-18.

${ }^{561}$ See Rom 9:32; 10.9; 11:20, 23; 1 Cor 1:21; 2 Thess $2: 13$.

562 See 1 Peter 3:21: "And baptism, which this prefigured, now saves you - not as a removal of dirt from the body, but as an appeal to God for a good conscience, through the resurrection of Jesus Christ."

${ }^{563}$ Campbell, Paul and Union, 272: "[B]ut it also stands in tension with Paul's clear conviction that believers are united to Christ by faith, not by an external rite. Furthermore, it does not do justice to Paul's apparently indifferent attitude toward the act of baptism; after all, if union with Christ was understood to be effected by the act of baptism, one would expect it to register more highly amongst Paul's priorities." This statement sums up the general sentiment amongst current New Testament scholars towards baptism and the Lord's Supper. However, nothing in Paul's letters explicitly denies the role of external rites the in union with Christ. Moreover, the impression that Paul appears uninterested in external rites derives from the fact that, in his letters, he focuses more on Christian living post-baptism, which is the last of the three stages of the ritual process.

${ }^{564}$ Wikenhauser, Pauline Mysticism, 123: "Fellowship with Christ is something objective which is established by Baptism. It is by faith that the Christian personally grasps this fellowship and develops it fully by leading a Christian life. Our fellowship with Christ has to assert itself constantly against the attacks of the life of the flesh."

${ }^{565}$ The present study recognises the elusiveness of giving an all-encompassing definition to the term ritual (see chapter 1). However, the advantage of choosing the term ritual over sacrament is that one can avoid the endless theological debates associated with baptism or sacraments: whether baptism is ex opera operato or how God infuses grace through sacraments to the individuals, all of which are beyond the inquiry of biblical studies. Instead, one can focus on the social and historical aspects of baptism (and other sacraments) and their impact on the participants on the social plane. 
and ritual, as re-configured terms, complement each other in union with Christ, as pistis is embodied, materialised, and created by the ritual performance of baptism and the Lord's Supper.

The argument of this chapter proceeds as follows. First are the definitions of pistis and ritual, which lay the foundation for the chapter. Second, the study offers an analysis of selected passages from Paul's letters pertaining to pistis and the rituals of baptism and the Lord's Supper, using the newly configured definitions established in the first section. Third, the various pistis formulae and their ritual counterparts are examined.

\subsection{Definitions of Pistis and Ritual}

Like ritual, pistis is a multifaced concept, encompassing a range of aspects to which no single definition can do justice. Often, scholars tend to delineate one aspect of pistis at the expense of the others. For instance, with the recent work of Teresa Morgan on pistis, there is a growing tendency to see pistis as a trust or confidence in the context of interrelationship. ${ }^{566}$ Whilst this move to correct the traditional reading of pistis as belief is welcome, Morgan has neglected those passages in Paul that use pistis to refer to the content of the gospel or confession of faith (Gal 1:23; 3:2). Francis Watson, in his brief rejoinder to Morgan's work, highlights 1 Cor 15:111 as the crux of the confession of faith in the nascent Christ religion, in which the term pistis acts "as metonym for the entire content of Christian preaching and teaching." 567 For this reason, he argues that pistis as a "counter-intuitive" belief in the resurrection of Jesus which constitutes divine promise should take precedence over the personal relationship of trust. ${ }^{568}$ Although Watson is correct to identify the overemphasis in Morgan's method of reading all instances of pistis in the New Testament in light of interpersonal trust, the issue of hierarchy between trust and belief is non-existent in Paul, for he does not privilege the importance of either one over the other. This is a "problem" concocted by modern scholars to grapple with the various aspects of pistis. Rather than pitting one aspect of pistis against the other, it would be better to recognise

\footnotetext{
566 Teresa Morgan, Roman Faith and Christian Faith: Pistis and Fides in the Early Roman Empire and Early Churches (Oxford: Oxford University Press, 2015), 261: "Paul's main interest is in pistis as relationshipforming. ... As such, he sees $\pi$ í $\tau \imath \varsigma \varsigma$ as predominantly an exercise of trust which involves heart, mind, and action. Like all trust, it is intimately connected with belief, on which it depends and which depends on it. That certain things are true, such as that Christ died for human sins and was raised from the dead, is integral to Paul's preaching, and he undoubtedly wants those to whom he preaches to believe them. But this kind of belief is not the essence of Paul's preaching nor of Christian pistis." See also David Konstan, "Trusting in Jesus," JSNT 40, no. 3 (2018): 247-54, in which faith is defined as a mutual recognition of trustworthiness.

${ }^{567}$ Francis Watson, “Quaestiones Disputatae: Roman Faith and Christian Faith,” NTS 64, no. 2 (2018): 244.

${ }^{568}$ Watson, “Quaestiones Disputatae”, 261.
} 
pistis as a multi-dimensional concept, and one needs to be sensitive to the multiple layers of meaning behind it.

To that end, we begin with the recognition that there are three aspects of pistis that need to be taken into consideration, as Douglas B. Miller has outlined: intellectual, dispositional, and performative. ${ }^{569}$ Pistis entails an intellectual understanding of biblical truisms (i.e., propositions), a trust in the future promises of God that will be realised, and an obedient action

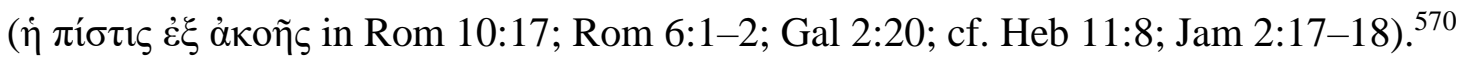

Besides these three basic facets of pistis, scholars employ a few other categories when speaking of the term. The first is the subjective or objective reading of the phrase $\pi$ í $\sigma i \varsigma$ $\chi \rho ı \tau \tau$ ov. ${ }^{571}$ An ocean of ink has been spilled over whether one should read the phrase as "faith in Christ" (the objective/anthropological reading) or "faith/faithfulness of Christ" (the subjective/Christological reading) since Richard Hays catapulted the issue into the centre of scholarly debate when he first proposed that $\pi i ́ \sigma \tau \iota \varsigma \chi \rho ı \sigma \tau o \tilde{~ s h o u l d ~ b e ~ r e a d ~ a s ~ " f a i t h f u l n e s s ~ o f ~}$ Christ." 572 Although the present study does not intend to offer a final answer on this perennial debate (which is not its focus), in line with the principle underlined above that one should not pit one aspect of faith against the others, we suggest that the debate suffers from the same either/or dichotomy and that, to overcome this impasse, one should take a both/and approach

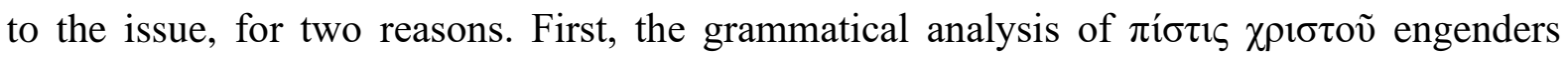
support from both sides of the debate. In other words, the grammatical construction is deliberately ambiguous, leading to both possible readings. ${ }^{573}$ Second, this is an example of the clashes in biblical hermeneutics between the world in the text and the world in front of the

${ }^{569}$ Douglas B. Miller, “The Nature of Biblical Faith,” Direction 44, no. 1 (2015): 72-83.

570 Miller, "Biblical Faith," 74-75.

${ }^{571}$ For a fair assessment of the debate from both sides, see Paul J. Achtemeier, "Apropos the Faith of/in Christ: A Response to Hays and Dunn," Pauline Theology, Volume IV: Looking Back, Pressing On, ed. Elizabeth Johnson and David M. Hay (Atlanta: Scholars Press, 1997): 82-92.

572 Richard B. Hays, The Faith of Jesus Christ: An Investigation of the Narrative Substructure of Galatians 3:1-4:11 (SBLDS 56: Atlanta: Scholars Press, 1983).

573 Those supporting the subjective reading: Douglas A. Campbell, "The Faithfulness of Jesus Christ in Romans 3:22," in The Faith of Jesus Christ: Exegetical, Biblical, and Theological Studies, ed. Michael F. Bird and Preston M. Sprinkle (Peabody, Mass. Hendrickson, 2009), 57-71, and Paul Foster, " $\pi$ í $\sigma \tau \iota \varsigma \chi \rho ı \tau o \tilde{~}$ Terminology in Philippians and Ephesians," in The Faith of Jesus Christ: Exegetical, Biblical, and Theological Studies, ed. Michael F. Bird and Preston M. Sprinkle (Peabody, MA: Hendrickson, 2009), 91-108. Those supporting the objective reading are R. Barry Matlock, "Saving Faith: The Rhetoric and Semantics of $\pi$ í $\tau \tau 1 \varsigma$ in Paul," in The Faith of Jesus Christ: Exegetical, Biblical, and Theological Studies, ed. Michael F. Bird and Preston M. Sprinkle (Peabody, MA: Hendrickson, 2009), 73-89, and Richard H. Bell, "Faith in Christ: Some Exegetical and Theological Reflections on Philippians 3:9 and Ephesians 3:12" in The Faith of Jesus Christ: Exegetical, Biblical, and Theological Studies, ed. Michael F. Bird and Preston M. Sprinkle (Peabody, MA: Hendrickson, 2009), 111-25. 
text. ${ }^{574}$ In accord with his transparency in methodology, Hays first approaches the issue from

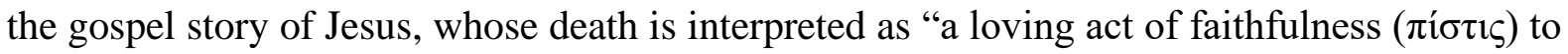
God and the decisive manifestation of God's faithfulness to his covenant promise to Abraham." 575 Then, he would use this as a paradigm to read all occurrences of $\pi i ́ \sigma \tau \iota \varsigma \chi \rho ı \sigma \tau o \tilde{v}$ in light of God's faithfulness to his covenant, whose manifestation is in the death of Jesus Christ. James D. G. Dunn, on the other hand, approaches this issue inductively; he starts with the form of the phrase in Paul and finds the subjective reading wanting. ${ }^{576}$ There is nothing inherently wrong with either approach. The latter is concerned with the historical meaning of the text (the world in the text), whereas the former deals with relatability to a contemporary readership. Tension arises when each arrives at different conclusions on the same topic. The recent study suggests that reading of an ancient text like the Bible, with a reading community spanning innumerable places and eras, is a living process consisting of historical meanings for the first audiences for whom it was intended and the later generations of readers who seek to draw applications from it; both feeding each other in a circularity of both layers of meaning.

Another category that scholars use to speak of pistis is its inner and outward aspects. Commenting on the pistis language in 1 Thess 1:3, Morgan writes:

It seems likely, therefore, that "work of pistis" (and perhaps also "labour of love") are to be read appositionally, and that pistis is being understood as both interior (something the Thessalonians can work on) and exterior, in the sense that it is relational and has an impact on others. ${ }^{577}$

Here Morgan distinguishes pistis as interior disposition and exterior action that flows from the interior faith. Regarding the interiority of pistis, the New Testament usually associates it with the assurance of future promises, whose vision is seen by the eyes of faith (Rom 4:12; 1 Cor 13:2; 2 Cor 5:7; Gal 5:5; 1 Thess 5:8; Titus 3:13; Heb 11). Regarding the exteriority of pistis, Paul deploys a series of verbs in connection with pistis in Rom 10, demonstrating the exteriority

574 This is illustrated by the reception of $\pi$ í $\tau \imath \iota \varsigma \chi \rho ı \sigma \tau o \tilde{v}$ amongst early patristic writers who are silent on the debate, and the existing evidence suggests that patristic writers use the phrase with the understanding of "faith in/through Christ." See Roy A. Harrisville, "Pistis Christou: Witness of the Fathers," NovT 36 (1994): 233-41;

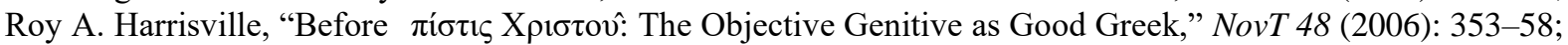

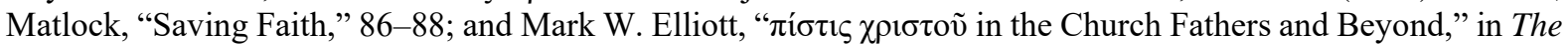
Faith of Jesus Christ: Exegetical, Biblical, and Theological Studies, ed. Michael F. Bird and Preston M. Sprinkle (Peabody, MA: Hendrickson, 2009), 277-89. Ian G. Wallis sees evidence for the notion of faithfulness in Christ in the early Greek writers; see his The Faith of Jesus of Christ in Early Christian Traditions, SNTSMS 84 (Cambridge: Cambridge University Press, 1995). Since these patristic writers carried the living memory of the apostles, it is not irrational to assume that their interpretations may be closer to the original intent of Paul; see Markus Bockmuehl, Seeing the Word (Grand Rapids: Baker Academic, 2006), 169. This is contrasted with the modern debate over $\pi i ́ \sigma \tau \iota \varsigma \chi \rho ı \sigma \tau o \tilde{v}$, which did not exist in the early period of Christ communities.

${ }^{575}$ Richard B. Hays, " $\pi 1 \sigma \tau 1 \varepsilon$ and Pauline Christology: What Is at Stake," Pauline Theology, Volume IV: Looking Back, Pressing On, ed. Elizabeth Johnson and David M. Hay (Atlanta: Scholars Press, 1997), 37.

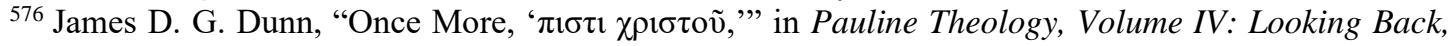
Pressing On, ed. Elizabeth Johnson and David M. Hay (Atlanta: Scholars Press, 1997), 61-81.

${ }^{577}$ Morgan, Roman Faith, 226. 


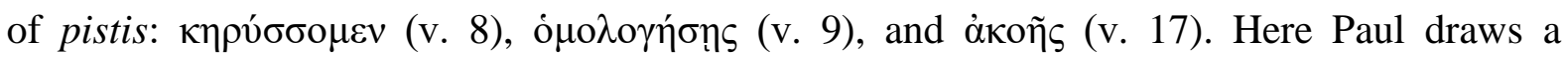
connection between pistis and the matrix of verbal actions. The seed of pistis is first planted in the heart of a person upon hearing the word of God, which in turn bears the fruit of pistis in the public proclamation. The author of the James letter also highlights exteriority of pistis when he writes, 'but someone will say, 'You have faith and I have works.' Show ( $\delta \varepsilon i \tilde{\xi}$ óv) me your faith apart from your works, and I by my works will show ( $\delta \varepsilon i \xi \omega)$ you my faith" (Jam 2:18). In dialogue with his (imaginary) opponents, the author of James challenges them to demonstrate their faith apart from works. Note that he uses the verb $\delta \varepsilon i \xi \omega$ in connection with pistis twice in the verse, indicating that a complete pistis is confirmed in the concrete works of righteousness (Jam 2:20-25). Thus, according to James a true pistis is a pistis shown, not a pistis hidden $(2: 26)$.

The final category that scholars deploy regarding pistis is its temporal sequence in the scheme of ordo salutis. Some speak of the role of pistis as a prerequisite that the candidate must acquire prior to baptism. ${ }^{578}$ For Herman Ridderbos, however, the role of pistis does not terminate at baptism: "For although baptism presupposes faith, the place of faith is not only prior to baptism, but in and after baptism as well." ${ }^{579}$ Indeed, pistis is first obtained upon hearing the word of God; then, it is proclaimed and confessed at baptism; ${ }^{580}$ finally, it continues to sustain the candidate post-baptism (cf. Heb 11).

The three facets and categories of pistis outlined above should demonstrate the multidimensional nature of the concept. ${ }^{581}$ Still, to fully comprehend its complexity, one needs to weave these various aspects together into a web of interconnections amongst the various categories. The chart below sets out the interrelationships amongst these various categories. ${ }^{582}$

578 Wikenhauser, Pauline Mysticism, 129: "Faith does not establish union with Christ, but it is the indispensable condition for the establishment of this union. We can say without qualification that without faith there is no union with Christ." Schnackenburg, Baptism in the Thought, 126: "Faith and baptism belong together, but they are at all times significant in themselves. In one relationship faith is the presupposition of baptism, in another it has a fundamental and independent position" (emphasis mine).

${ }^{579}$ Ridderbos, Paul: An Outline, 412.

${ }^{580}$ For the correlation between the earliest creeds and baptism, see Malcolm Ruel, "Christians as Believers," in Ritual and Religious Belief: A Reader, ed. Graham Harvey (London: Equinox, 2005), $247-48$.

${ }^{581}$ Cf. J. Lyle Story, "Facets of Faith/Trust in Pauline Thought," American Theological Inquiry 5, no. 1, 2012): 101-15, in which Story delineates seven facets of faith: 1) faith as God's gift; 2) faith as conviction; 3) faith as personal trust; 4) faith as faith-union with Christ, which is also the pre-requisite for the Holy Spirit's indwelling; 5) faith as a growing responsiveness to God's work in the Christian life; 6) faith as the living deposit of Christian belief; and 7) faith as expressed in the context of the Christian community.

582 The way this chart is set up may seem artificial to some; nevertheless, we suggest that it captures the various and sometimes confusing proposals on the definition of pistis in the scholarship. This chart is a testament to the multi-dimensional nature of pistis and shows how various proposals can be synthesised in an intelligible manner. 


\begin{tabular}{|l|l|l|l|}
\hline & Intellectual & Disposition & Performative \\
\hline Objective & Belief & Confidence, trust & $\begin{array}{l}\text { Hearing, obedience, } \\
\text { confession, works }\end{array}$ \\
\hline Subjective & & Confidence, trust & $\begin{array}{l}\text { Faithfulness of Christ } \\
\text { (Christ event) }\end{array}$ \\
\hline Inward & Belief & Confidence, trust & $\begin{array}{l}\text { Confession of mouth, } \\
\text { preaching and hearing of } \\
\text { the words, works of } \\
\text { righteousness }\end{array}$ \\
\hline Outward & & & Confession of pistis \\
\hline Temporality: Before & Belief & Confidence, trust & Promises \\
\hline Temporality: During & & & Confidence, trust \\
\hline
\end{tabular}

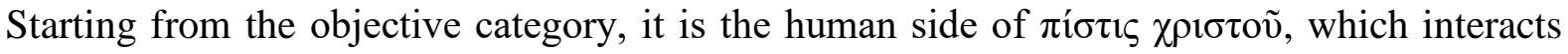
with three facets of pistis. It intellectually assents to the belief in the resurrected Christ, puts trust in the promise by God of future resurrection, and acts upon the conviction in proclaiming the word of Christ, obeying the commandments of God, and doing good works. The subjective category, the divine side of $\pi i ́ \sigma \tau \iota \varsigma \chi \rho ı \tau \tau o \tilde{v}$, pertains to the faithfulness of Christ, who put his trust in his heavenly father and became obedient to death on the cross to fulfil the promise of God. ${ }^{583}$ The inward category interacts only with the intellectual facet of pistis in asserting the truths of the person of Christ and Christ event. If one has an inward disposition of trust and confidence, it would naturally be shown in action. One cannot have inward trust and not show it in outward activities, which leads to the outward category, interacting with the activity facet of pistis. ${ }^{584}$ Lastly, the temporal category interacts with all facets of pistis at different points relative to baptism. Prior to baptism, the candidate would have obtained an intellectual and dispositional aspect of pistis. During the baptism, the candidate manifests these two aspects publicly in a confession of pistis and the very act of baptism. After the baptism, the neophyte is confirmed in the pistis into which he or she has been baptised, cementing his or her belief in the resurrected Christ and its salvific event, establishing a divine-human relationship, and expecting fervently the future fulfilment of the promises of God.

Having established what pistis entails globally, attention now turns to ritual. As a caveat, the term ritual(s) does not appear in the New Testament; nor does the word sacrament(s). The latter is a theological term devised to describe how God infuses grace into humans through the

${ }^{583}$ See John-Christian Eurell, "Faith: An Activity of Christ or of the Believer? A Contribution to the

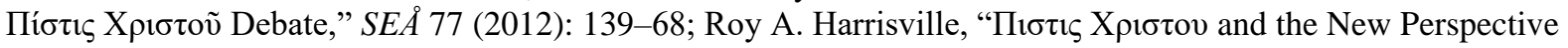
on Paul," Logia 19, no. 2 (2010): 19-28; and R. Bruce Compton, "The 'Ordo Salutis' and Monergism: The Case for Faith Preceding Regeneration, Part 3,” BSac 175, no. 699 (2018): 284-303. All three argue that faith originates solely from God and is therefore a gift.

${ }^{584}$ See Patrick J. Hartin, "The Letter of James: Faith Leads to Action (The Indicative Leads to the Imperative)," $W W 35$, no. 3 (2015): 222-30. 
rites of baptism, the Lord's Supper, and others. The former is a modern category devised to analyse religious rites and ceremonies across different faith traditions. ${ }^{585}$ The focus of the present study is not how pistis relates to baptism and the Lord's Supper sacramentally. Rather, it examines how pistis relates ritually to these two major rites of nascent Christ religion: what role does pistis play in the overall scheme of rituals, using the ritual transformation model? For this reason, this study uses the working definition of ritual established in chapter one above, which defines ritual as performance:

Ritual performance is a ritual action whose structure includes a logical object and appeals to culturally postulated superhuman agents, which entails the generation of the concept of the sacred and the sanctification of the conventional order whose function is penetration into human actualities, enactment of exceptional relationships, and emergence of social realities.

This definition of ritual is employed in the examination of the relationship between pistis and ritual.

The point of contact between the two is the performative facet of pistis, since the ritual is essentially a physical activity (with a cognitive understanding). The objective and subjective categories of pistis correspond to the divine and human agents in the ritual performance; the outward to the ritual performance itself, and the temporal to the pre-liminal, liminal, and postliminal states of the ritual. Furthermore, the performative aspect of pistis consists of sensory activities (hearing, confessing, seeing, doing good works) and embodied character traits (obedience, faithfulness), whereas ritual performance entails the acts of dramatising the ritual scenes represented by their ritual symbols. This raises the question of how these two types of activities are related to each other. The present study suggests that ritual provides a physical embodiment to the performative facet of pistis in which a new reality of faith is created. ${ }^{586}$ The sensory activities of pistis are concretised at baptism when the candidate recites or proclaims the creedal statements. The ritual gestures that embody the disposition of obedience and faithfulness are re-enacted during the performance of the ritual.

${ }^{585}$ For a historical survey of the reification of ritual, see Catherine Bell, "Ritual Reification" in Ritual and Religious Belief: A Reader, ed. Graham Harvey (London: Equinox, 2005), 265-83.

${ }^{586}$ Cf. Gary S. Selby, “(Em)Bodying the Faith: Baptism as Ritual Communication," Res $Q$ 48, no. 1 (2006): 8: "Much more, through bodily performance, it [baptism] actually brings the consciousness offaith about. In other words, baptism takes the abstract self-referential dimensions of becoming a Christian - having faith, accepting grace, obeying the Gospel - and makes them 'real' to the convert by means of a concrete, bodily act." Italics author. 


\subsection{The Relationship between Pistis and Ritual}

With this understanding of how pistis and ritual interact with each other, this study will turn to selected passages in Paul that contain references to both pistis and the rituals of baptism and the Lord's Supper:

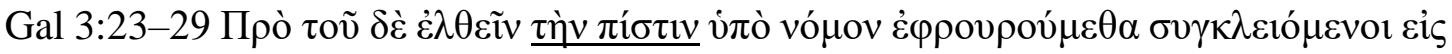

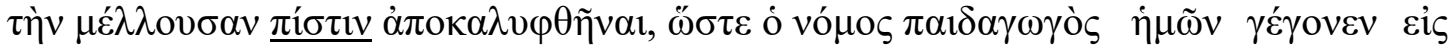

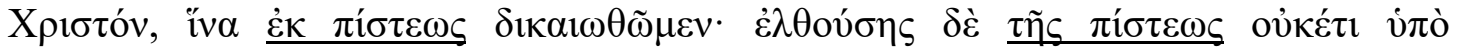

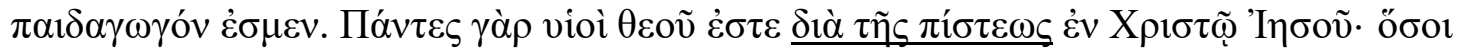

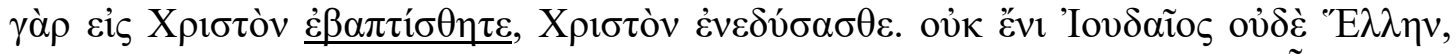

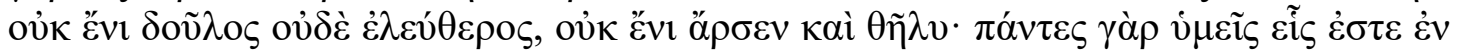
X

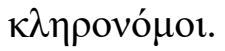

Pistis appears four times in this passage. It functions under two categories: subjective and objective ${ }^{587}$ Subjectively, the pistis in vv. 23, 24, and 25 refers to Christ or the Christ event. This is confirmed by the use of the verbs $\dot{\varepsilon} \lambda \theta \varepsilon \tilde{v} v$ and $\dot{\alpha} \pi \circ \kappa \alpha \lambda \nu \varphi \theta \tilde{\eta} v \alpha$ to describe the advent of pistis, which, for Paul, is the fulfilment to the promise made to Abraham. ${ }^{588}$ Objectively, the

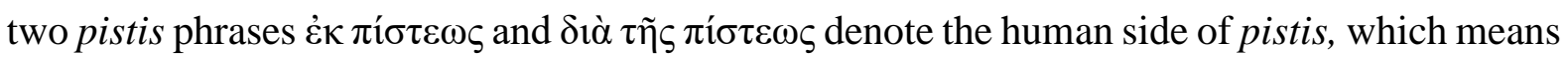
putting one's trust and confidence in Christ and the Christ event. The same phraseology of pistis appears in Gal 2:16 in which Paul emphatically states that one is not put right

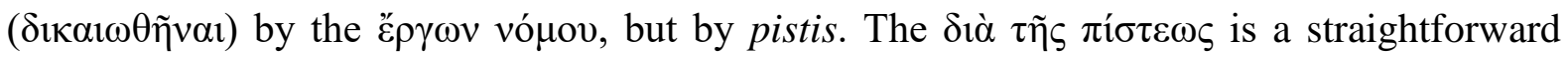
phrase, denoting the instrumentality of pistis in the overall scheme of personal salvation. The $\dot{\varepsilon} \kappa \pi i ́ \sigma \tau \varepsilon \omega \varsigma$ phrase, as Don B. Garlington has demonstrated, denotes a specific theological meaning in Paul's choice of preposition; namely, the notions of source and belonging, implying that $\delta 1 \kappa \alpha$ is no longer grounded in the old community that observes Mosaic law, but in the new community that came into existence through "Christic faith." 589 Thus, the instrumentality and

587 These categories might strike some as artificial; however, they are directly derived from the scholars who designate and deploy them as a frame of reference to grapple with the notion of pistis; these categories are used as heuristic tools.

${ }^{588}$ See Schliesser, Benjamin, “'Christ-Faith’ as an Eschatological Event (Galatians 3.23-26): A 'Third

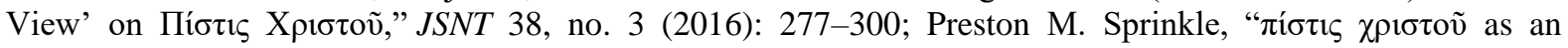
Eschatological Event," in The Faith of Jesus Christ: Exegetical, Biblical, and Theological Studies, ed. Michael F. Bird and Preston M. Sprinkle (Peabody, MA: Hendrickson, 2009), 180: “According to the 'third view,' $\pi$ í $\sigma \tau \varsigma$ $\chi \rho ı \sigma \tau o \tilde{v}$ refers not to the Son's earthly character or disposition toward the cross, nor to the believer's response of

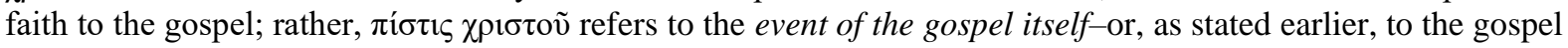

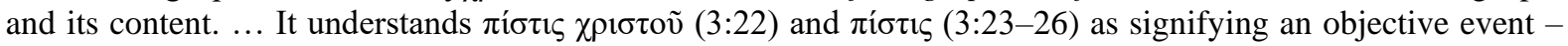
God's saving act in Christ. It is not so much the Son's role or disposition within that event, but the event itself." Italics author.

${ }^{589}$ Garlington, Don B. 'Paul's 'Partisan Eк' and the Question of Justification in Galatians,” JBL 127, no. 3 (2008): 574. 


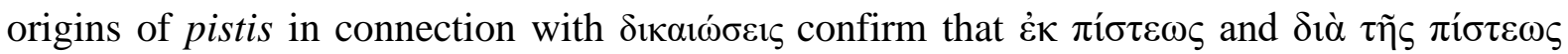
should be read objectively.

With these two aspects of pistis delineated, we now examine how it relates to baptism in v. 27. The initial observation begins with the parallel statements in Gal 3:23-29 and Gal 2:15-21. There are two reasons for reading these texts side by side. First, they share the view that justification originates not from observing Mosaic law but from having confidence and trust in Christ, who is the true descendent of Abraham and fulfils all the stipulations of the Law. Second, the present study argues that the crucifixion language in Gal 2:19b-20a ( $\sigma v v \varepsilon \sigma \tau \alpha v ́ \rho \omega \mu \alpha \imath)$ relates to baptism, since the same imagery of being "co-crucified with Christ' appears in Rom 6:6, which relates to baptism. ${ }^{590}$ Moreover, as Morales has observed, Paul speaks of his own crucifixion and that of the Galatians as decisive moments in their conversion to Christ, and this usually takes place at baptism. ${ }^{591}$

We can now compare the two texts and observe the events that lead to baptism that correspond to the three stages of the ritual process: pre-liminal, liminal, and post-liminal. Pistis plays a role throughout all three stages.

\begin{tabular}{|c|c|c|}
\hline & Galatians 3:23-29 & Galatians 2:15-21 \\
\hline Pre-liminal & $\begin{array}{l}\text { Now before faith came, we were } \\
\text { imprisoned and guarded under the } \\
\text { law until faith would be } \\
\text { revealed. Therefore the law was } \\
\text { our disciplinarian until Christ } \\
\text { came, so that we might be justified } \\
\text { by faith. But now that faith has } \\
\text { come, we are no longer subject to a } \\
\text { disciplinarian. }\end{array}$ & $\begin{array}{l}\text { We ourselves are Jews by birth and } \\
\text { not Gentile sinners; yet we know } \\
\text { that a person is justified not by the } \\
\text { works of the law but through faith } \\
\text { in Jesus Christ. }\end{array}$ \\
\hline Liminal & $\begin{array}{l}\text { As many of you as were baptized } \\
\text { into Christ have clothed yourselves } \\
\text { with Christ. }\end{array}$ & $\begin{array}{l}\text { I have been crucified with } \\
\text { Christ; and it is no longer I who } \\
\text { live }\end{array}$ \\
\hline Post-liminal & $\begin{array}{l}\text { There is no longer Jew or Greek, } \\
\text { there is no longer slave or free, } \\
\text { there is no longer male and female; } \\
\text { for all of you are one in Christ } \\
\text { Jesus. And if you belong to Christ, } \\
\text { then you are Abraham's } \\
\text { offspring, heirs according to the } \\
\text { promise. }\end{array}$ & $\begin{array}{l}\text { But it is Christ who lives in me. } \\
\text { And the life I now live in the flesh } \\
\text { I live by faith in the Son of } \\
\text { God, who loved me and gave } \\
\text { himself for me. }\end{array}$ \\
\hline
\end{tabular}

${ }^{590}$ Many commentators have read the crucifixion language in Gal 2:19-20 as a reference to baptism. See Franz Mussner, Der Galaterbrief, 5th ed., HTKNT 9. (Freiburg: Herder, 1988), 180-81; Wilfried Eckey, Der Galaterbrief: Ein Kommentar (Neukirchen-Vluyn: Neukirchener, 2010), 147; and Thomas Söding, Kreuzestheologie und Rechtfertigungslehre: Zur Verbindung von Christologie und Soteriologie im Ersten Korintherbrief und im Galaterbrief," in Das Wort vom Kreuz: Studien zur paulinischen Theologie, WUNT 93 (Tübingen: Mohr Siebeck, 1997), 153-82, especially 170.

${ }^{591}$ Morales, "Baptism and Union," 171-73. 


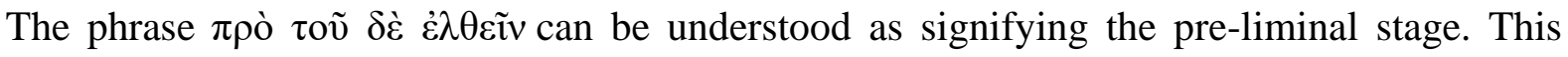
condition is marked by bondage under the Law, being subject to all its regulations $(3: 23)$, or the sinful state if one is outside of the Mosaic covenant (2:15). Pistis at this pre-ritual stage functions as a prerequisite that prepares candidates for baptism by introducing them to Christ, which is revealed pistis. This revelation for Paul takes the form of the encounter with the divine on the road to Damascus, whereas for Paul's readers, who have not seen Christ personally or in a vision, pistis is embodied in the proclamation of the gospel and through hearing the word of Christ. Moreover, pistis is required at this stage for the legal pronouncement of justification, nullifying all the condemnations that may lay claims on the individual under the Law (Gal $3: 10-13$; Rom 4:15; 5:13, 20). This legal pronouncement is ratified at baptism, the liminal stage. If the baptism formula in 3:27-28 is part of the earliest baptismal liturgy in the nascent Christ religion, then we have here a declaration of pistis in the ritual setting. The performative aspect of pistis taking the form of a public declaration is ritualised and concretised at this important moment in the lives of Christ followers. Moreover, the pistis of the Christ event is re-enacted and re-created in the performance of baptism, when one is fully immersed in water.

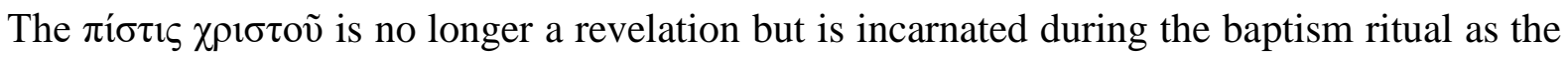
candidate takes on $(\dot{\varepsilon} v \varepsilon \delta \dot{\sigma} \sigma \alpha \sigma \theta \varepsilon)$ Christ and Christ lives in them. In the post-liminal stage, a new creation emerges as the candidates receive a new identity in Christ and become the offspring of Abraham. Pistis sustains the lives of the candidate post-baptism as it becomes the

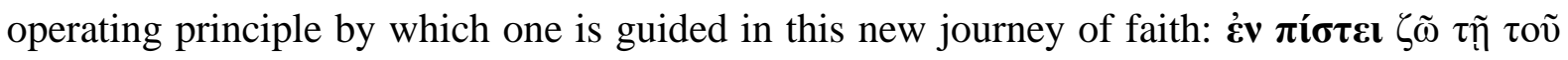

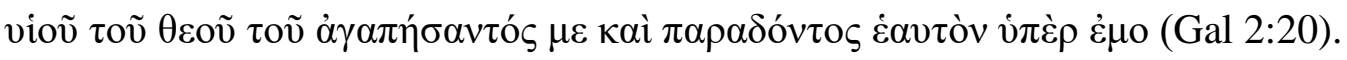

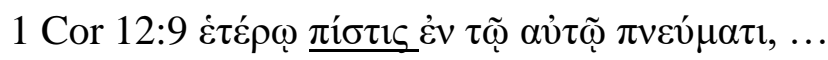

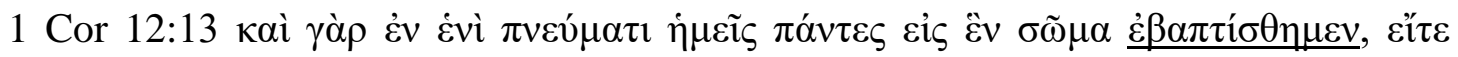

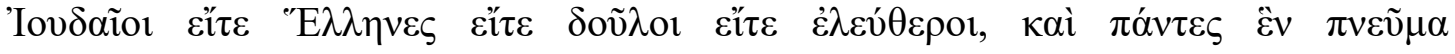
$\dot{\varepsilon} \pi \mathrm{o} \tau \dot{\sigma} \sigma \eta \mu \varepsilon v$.

The pistis in this passage (12:9) refers to the gift of the Spirit, given the beginning of the chapter: $\pi \varepsilon \rho i ̀ ~ \delta \dot{\varepsilon} \tau \tilde{\omega} \nu \pi v \varepsilon v \mu \alpha \tau \iota \kappa \tilde{\omega} \nu$ (12:1). Here, the meaning of pistis is contested. Some argue that since

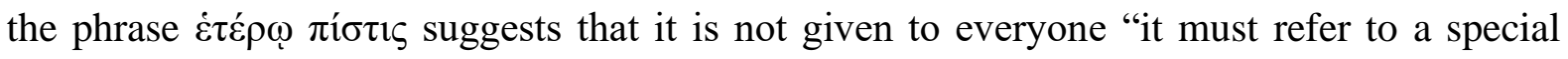
endowment and not saving trust that is required of all Christians." 592 Morgan, on the other hand, argues that pistis here refers to the intra-divine-human trust:

${ }^{592}$ Garland, 1 Corinthians, 581. 
Given that gifts of the spirit are all qualities which are enacted within the community in relation to other pisteuontes, a plausible interpretation is that pistis here is the committed trust in God and service to God which enables other community members to trust the person who has it and treat him or her as a "steward of the mysteries of God." 593

This study concurs with Morgan that the gift of pistis is a living intra-divine-human quality that the Christ community should embody for two reasons. First, Paul provides three lists of the spiritual gifts in chapter 12, but none is complete or exhaustive. In fact, some overlap with one another or omit gifts that appear in other lists, including pistis. Paul mentions pistis in 12:8-10, but it is totally absent from the other two lists: 12:28 and 12:29-30. This might imply that Paul views pistis as a foundational quality for all Christ followers regardless of the gift or position they have received in Christ's body. Indeed, pistis relates to healings, miracles, and prophecies (Matt 16:8; 21:21; Mark 5:34; 10:52 Luke 17:5-6; Heb 11:29-30; James 5:15; Rom 12:6). Second, pistis is mentioned twice in chapter 13, where Paul directs the attention from pursing spiritual gifts to pursuing the virtue of love, which lasts forever. In the two instances

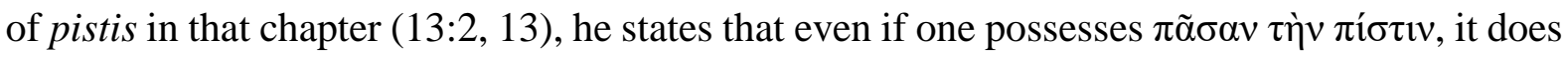
not profit them at all, and notes that pistis is amongst the three cardinal qualities that still abide ( $\mu \varepsilon \dot{v \varepsilon l) ~ a t ~ t h e ~ m o m e n t . ~ B a s e d ~ o n ~ t h e s e ~ t w o ~ s t a t e m e n t s ~ r e g a r d i n g ~ p i s t i s, ~ o n e ~ c a n ~ d e d u c e ~ t h a t ~}$ pistis is a general property of all Christ followers at present, regardless of the degree with which any given follower possesses it.

Although Morgan discerns the intra-divine-human pistis in this passage, she does not consider how this pistis is ritually re-enacted; that is, how baptism relates to pistis. The structure of chapter 12 evinces the relation between the two.

\begin{tabular}{|l|l|}
\hline The source of spiritual gifts & $\begin{array}{l}\text { 1 Cor 12:4-11: Now there are varieties of gifts, but the } \\
\text { same Spirit; and there are varieties of services, but the } \\
\text { same Lord; and there are varieties of activities, but it } \\
\text { is the same God who activates all of them in } \\
\text { everyone. }\end{array}$ \\
\hline Baptism/Incorporation into the body of Christ & $\begin{array}{l}\text { 1 Cor 12:12-26: For just as the body is one and has } \\
\text { many members, and all the members of the body, } \\
\text { though many, are one body, so it is with Christ. For in } \\
\text { the one Spirit we were all baptized into one body - } \\
\text { Jews or Greeks, slaves or free - and we were all made } \\
\text { to drink of one Spirit. }\end{array}$ \\
\hline The allocation of gifts to members of Christ's body & $\begin{array}{l}\text { Cor 12:27-28: Now you are the body of Christ and } \\
\text { individually members of it. And God has appointed in } \\
\text { the church first apostles, second prophets, third } \\
\text { teachers; then deeds of power, then gifts of healing, } \\
\text { forms of assistance, forms of leadership, various kinds } \\
\text { of tongues. }\end{array}$ \\
\hline
\end{tabular}

${ }^{593}$ Morgan, Roman Faith, 257. 
In the first section of chapter 12, Paul states that the source of all gifts and services in Christ's body is the same Spirit that distributes sundry gifts to all for the edification of Christ's body, including the gift of pistis. Paul devotes the second section to the discussion of how pistis is realised amongst the members of Christ's body. First, baptism incorporates individual members to the $\sigma \tilde{\omega} \mu \alpha$. The present study has discussed in chapter 2 that a new kind of relationship amongst the participants is formed at baptism. Now, this new relationship hinges on the kind of pistis that Morgan describes as having a committed trust to God and towards those who have been tasked with being stewards of the mysteries of God. Since $\sigma \tilde{\omega} \mu \alpha$ is one of the images of the baptism ritual, the extensive exchange in 12:15-21 between the members of $\sigma \tilde{\omega} \mu \alpha$ is a ritual performance of one of the ritual scenes, demonstrating how members resolve the issue of distrust and arrive at the unity of $\sigma \tilde{\omega} \mu \alpha$. The result of performing this ritual scene creates a unity of Christ's body, with each provided with certain gifts of the Spirit for the edification of all members.

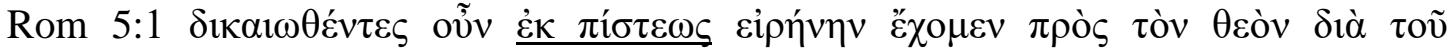

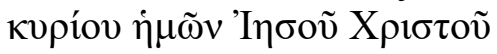

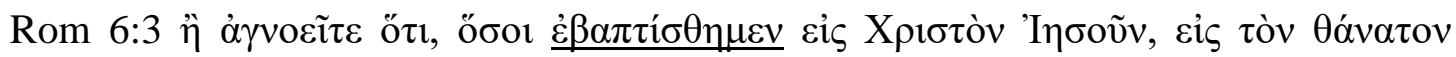

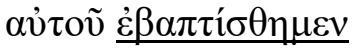

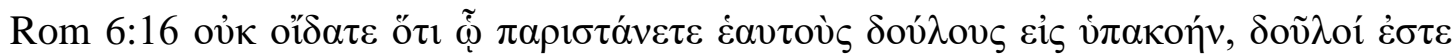

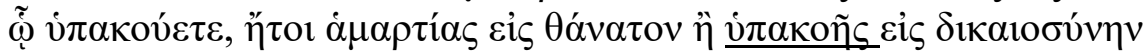

Pistis appears numerous times in Romans, with some occurrences having a performative aspect: a pistis that is proclaimed and heard $(10: 8 \mathrm{~b}, 17$; cf. 10:9); a pistis that makes obedience to the gospel (1:5; 16:26); and a pistis that justifies sinners becoming righteous before God (Rom 3: 28, 30-31; 5:1). Thus, pistis in Romans functions as more than a human response to the gospel. It is a crucial operating principle in the overall scheme of the trajectory salvation. The question arises of how this performative aspect of pistis relates to baptism.

To answer, we first need to examine the context in which baptism appears in the Romans discourse. Unlike the other three passages that we have examined with baptism and pistis in close proximity, the mentions of baptism in Rom 6:1-11 are generally free of the pistis motif, except for v. 8.b, where it refers to the future resurrection. ${ }^{594}$ However, if we keep the context of Rom 6:1-11 in mind while considering the larger discourse of the letter, we find that the rhetorical interrogative $\tau$ í oṽv $\dot{\rho} \rho o \tilde{\mu} \mu \varepsilon v$ connects logically with the previous chapter, for it

${ }^{594}$ Penna, Paul the Apostle, 135. 
signals a turning point in Paul's thought at both the macro and micro levels (Rom 3:1, 5, 9; 4:1; $6: 1,15 ; 7: 7 ; 8: 31 ; 9: 14,30 ; 11: 17) .{ }^{595}$ Thus, we find pistis in the opening verse of chapter 5 , where it relates to dikaiosyne. Another pistis is found within the larger discourse in Rom 6:16b,

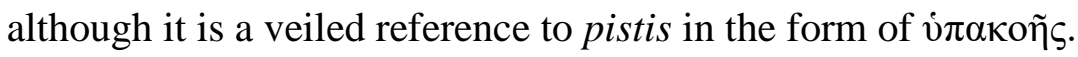

Before we examine how these two uses of pistis relate to baptism, a brief remark on them is in order. Commenting on the meaning of pistis relative to dikaiosyne, Morgan writes that pistis "could also mean the 'assurance' or 'pledge' of dikaiosyne which Christ gives to the faithful by his blood. This assurance would presumably be that, as they exercise pistis, human beings are made dikaioi. ${ }^{596}$ By extension, Morgan argues that, by understanding pistis as a pledge, it is logical to argue that it would come to be heard as "the (new) covenant" amongst first-century Christ followers. There are two reasons to support this interpretation of pistis. First, Paul makes a comparison between how one receives righteous status under the Law and with the advent of faith. Regarding the former, Paul writes: "For it is not the hearers of the law who are righteous in God's sight, but the doers of the law who will be justified," and "Circumcision indeed is of value if you obey the law; but if you break the law, your circumcision has become uncircumcision" (Rom 2:13; 2:25; cf. Gal 3:10; James 2:8-11). These two statements show that one can, theoretically speaking, achieve a righteous status before God by executing all the stipulations encoded in the Law. However, Paul recognises that this is impossible with solely human effort, for we all have sinned (Rom 3:9-19 and especially 3:23). Regarding the latter, Paul writes: "But now, apart from law, the righteousness of God has been disclosed, and is attested by the law and the prophets, the righteousness of God through faith in Jesus Christ for all who believe" (Rom 3:21). Since no one can obtain justification under the Law, a new path has been opened to all by the pistis of Christ, who fulfils all the terms and stipulations of the Law (Rom 3:24-26; Matt 5:17-20). Pistis is the means by which one gains entry to Christ's pistis and thus becomes righteous before God. ${ }^{597}$ Second, this is further confirmed by the author of Colossians: "In him also you were circumcised with a spiritual circumcision, by putting off the body of the flesh in the circumcision of Christ; when you were buried with him in baptism, you were also raised with him through faith in the power of God,

595 See F. Siegert, Argumentation bei Paulus, gezeigt an Röm 9-11, WUNT 34 (Tübingen: Mohr Siebeck, 1985), 115

${ }^{596}$ Morgan, Roman Faith, 290.

${ }^{597}$ A similar idea is expressed in Galatians, where Paul argues that Christ is the true heir of the promise of Abraham. People can become children of Abraham by connecting to Christ, who adopts them as sons and daughters of God (Gal 3); see also Paul's discourse on the grafting of the Gentiles to the olive tree (Rom 11:1131). 
who raised him from the dead" (Col 2:11-12). ${ }^{598}$ Note that the author of Colossians compares circumcision with baptism, although he refers to spiritual circumcision. Both are outward ceremonies that ratify the covenant under the Law and the new covenant based on pistis of Christ. Thus, Morgan's interpretation of pistis in Romans as a metonymy for the new covenant is plausible. ${ }^{599}$

Apropos of $\dot{v} \pi \alpha \kappa o \tilde{\varsigma} \varsigma$ in Rom 6:16b, we argue that it is a synonym for pistis, a performative aspect of pistis, a pistis that is shown in obedience to the commandments of God. ${ }^{600}$ This is in line with Paul's usage of pistis in Rom 1:5, 10:16, and 16:19, 26. ${ }^{601}$ How, then, should one interpret the meaning of $\dot{\pi} \alpha \alpha \operatorname{con} \pi \dot{\imath} \sigma \tau \varepsilon \omega \varsigma$ ? Interpreting pistis as a sphere of influence that lays claim on the people involved, Benjamin Schließer writes that "for that reason, one should understand $\dot{\pi} \pi \alpha \kappa o \eta ́ ~ \pi i ́ \sigma \varepsilon \omega \varsigma$ as human obedience towards the authority exercised by the reality of faith, which God has created and put under the lordship of Jesus Christ." ${ }^{\circ 02}$ As in the discussion of Gal 3:23-29 above, pistis is interpreted as a Christ event revealed at alter time. Pistis in Rom 6:16 could also refer to the eschatological event inaugurated by Christ's death and resurrection, as Paul has painted with vivid images in vv. 26. Hence, Paul may have this in mind when he writes just a few verses down when admonishes his readers to be slaves to righteousness rather than the flesh, for they have been purchased by the blood of Christ for a price.

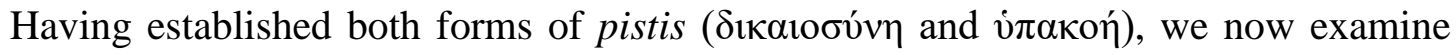
how they interact with the baptism ritual. We begin with how pistis relates to dikaiosyne. Since

${ }^{598}$ It is worth comparing this passage with how pistis was understood in Graeco-Roman religiosity along the similar line of acquiring righteousness. Two examples will be cited. Epictetus claims that human beings are endowed with a series of virtues, including pistis, and it behoves humans to acquire virtues and imitate the god: "If the divine is trustworthy, he must be trustworthy too" (2.14.11-14). Philo of Alexandria frames pistis as a crucial element in a relationship between a righteous person and God. According to Philo, it is difficult for humans to place their trust in God as they are often persuaded otherwise by contingent things such as wealth, friends, and power. Therefore, it requires one to take exceptional understanding to trust in God and such a person should be reckoned as dikaiosyne (Her. 90-4; cf. Abr. 43-4). See also Morgan, Roman Faith, 132-33, 152-54.

${ }^{599}$ Macaskill (Union with Christ, 238) also detects a covenantal concept present in Rom 6:3-4 in the juxtaposition of Paul's use of baptism imagery in Rom 6 with marriage imagery in Rom 7. Nevertheless, he does not note the relationship between pistis in Rom 5 and baptism in Rom 6. Now, if we take all three together, we observe a chiastic structure: A-B-A' - pistis (pledge/covenant) - baptism - marriage (covenant).

${ }^{600}$ Morgan, Roman Faith, 136.

${ }^{601}$ Sherif A. Fahim distinguishes between obedience and faith, viewing each as a separate category: "The subjective genitive denotes that obedience finds its fountainhead in faith. Accordingly, when anyone is saved through faith, the view is to obedience. This view is supported by such passages as Philippians 2:12 and Colossians 3:20, 22. Therefore, Paul was thinking of faith not only as obedience but also as the obedience of love that faith produces (1 Tim 1:5). The same idea of obedience that flows out of faith is also clear in Romans 6:16, where Paul's concern is Christian obedience"; see Sherif A. Fahim, "Obedience of Faith in Romans 1:5," Puritan Reformed Journal 9, no. 2 (2017): 55.

${ }^{602}$ Benjamin Schließer, Abraham's Faith in Romans 4, WUNT 222 (Tübingen: Mohr Siebeck, 2007), 399. 
we have understood pistis in Rom 5:1 as a pledge or new covenant through which sinners are made righteous before God by the blood of Christ, it is logical to view Rom 5:6-11 as a condensed form of a covenant document. In the old (Mosaic) covenant there are four elements, the exodus (Exod 14-15), sealing the covenant (Exod 24:5-8), giving the Law (Exod 20-23), and covenant rituals (Ex 27-28, 37-40). Likewise, Rom. 5:6-10 narrates a salvific event like

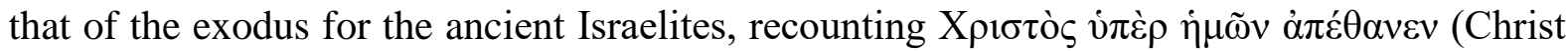
died for us), a phrase that recalls how Paul speaks earlier (1 Cor 5:7) of Christ as the Paschal lamb that has been sacrificed. The sealing of the new covenant is the blood of Christ rather than animal blood (cf. Heb 9:7, 12-14, 18-21; 10:4, 19, 29). The ritual used to ratify the new covenant is baptism (Rom 6:1-11). Baptism is the ritual that initiates the candidate (ö $\sigma 01$

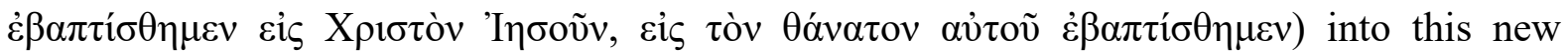
covenant. This is followed by the new law that is stipulated in Rom 6:12-23, in which Paul urges his readers to live in accordance with the new reality that has been bestowed upon them through baptism. Their lives post-baptism are guided by the law of Christ (1 Cor 9:21; Gal 6:2; cf. James $1: 25 ; 2: 12$ ). We now move to the second form of pistis, vi $\pi \alpha \kappa o \eta ́ ~ \pi i ́ \sigma \tau \varepsilon \omega \varsigma$. Based on

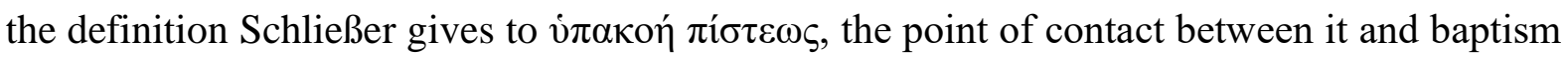
is in the latter part of the definition, which consists of two elements: the reality of faith created by God and the lordship of Jesus Christ. Although some argue that the Christ event is "the stoeriologically preexisting datum" that is independent of the baptism ritual, the reality of faith is also created or actualised in the performance of that ritual for the candidates in the present moment. ${ }^{603}$ This is confirmed by the statement that unequivocally pronounces on the

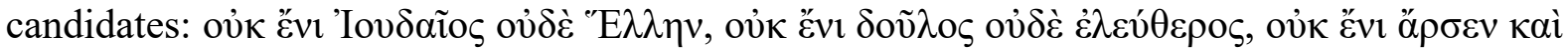

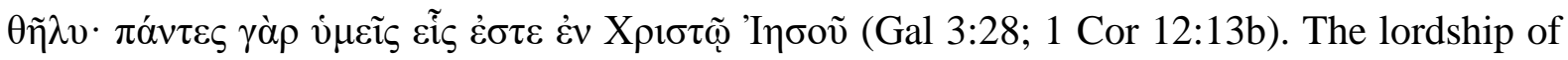
Christ lays claim on the candidates when they are baptised in the name of Jesus Christ $(\tau \tilde{\omega}$ ỏvó $\mu \alpha \tau \imath ' I \eta \sigma o \tilde{~ X \rho ı \sigma \tau o v ̃ ; ~ A c t s ~ 2: 38 ; ~ c f . ~ M a t t ~ 28: 19) . ~ A l t h o u g h ~ t h e r e ~ a r e ~ v a r i o u s ~ i n t e r p r e t a t i o n s ~}$ of the meaning of the formula, they all lead to the same reality: the candidates have surrendered themselves to Christ, giving up their own will, so that it is not that they live but that Christ lives

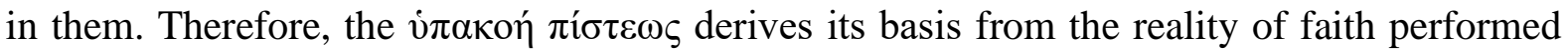
and actualised in baptism.

Based on this discussion of the relations between two forms of pistis and baptism, the relationship between the three can be viewed as follows:

\section{$\delta 1 \kappa \alpha 10 \sigma u ́ v \eta \dot{\varepsilon ̇ \kappa} \pi i ́ \sigma \tau \varepsilon \omega \varsigma \rightarrow$ baptism $\leftarrow \dot{v} \pi \alpha \kappa o \eta ́ ~ \pi i ́ \sigma \tau \varepsilon \omega \varsigma$}

\footnotetext{
${ }^{603}$ Penna, Paul the Apostle, 132.
} 
The first form of pistis finds its actual embodiment in the form of baptism, as it refers to a new covenant that is ratified with a ritual performance. The second form of pistis derives its authority from the reality that is created at baptism. It is baptism, then, that stands at the nexus

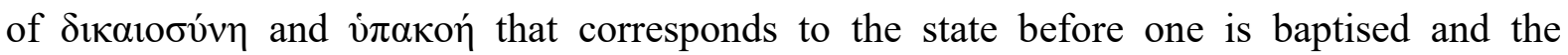
disposition that one needs to adopt after baptism.

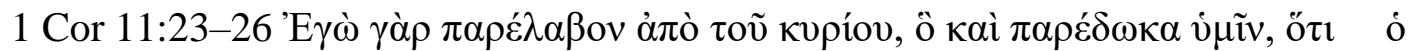

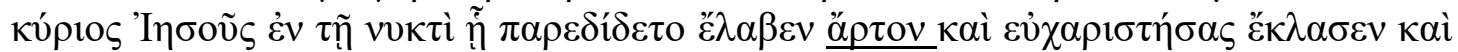

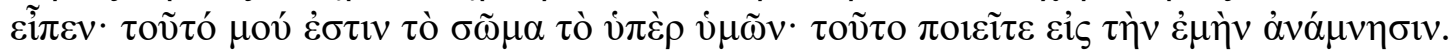

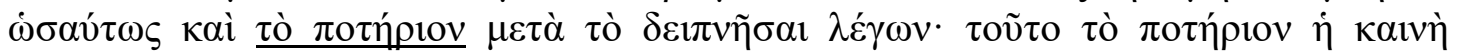

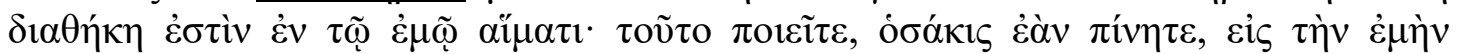

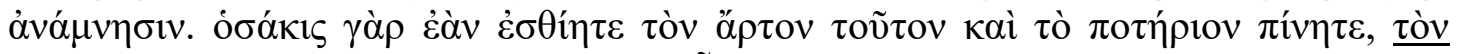

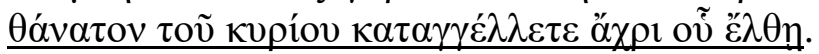

The relationship between pistis and the Lord's Supper is not as conspicuous as baptism that is closely intertwined with the confession of faith. There are several possible reasons for the apparent lack of a link between pistis and the Lord's Supper. First, since baptism is seen as an entry rite for qualified candidates, it naturally requires the baptised to publicly announce their allegiance to the Christ religion at the time of their admission to the Christ community. Second, the Lord's Supper is an internal ritual for the already baptised members of Christ's body; it

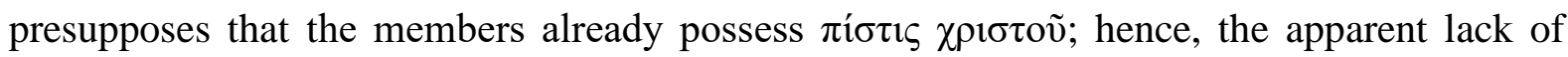
emphasis on pistis. Finally, in the theological discourse it is common to allocate the discussion of the role of pistis, along with baptism, to the initial stage of the ordo salutis, resulting in the impression that pistis has no bearing on the lives and practices of Christ followers post-baptism, which includes the regular celebration of the Lord's Supper.

Having offered reasons for the apparent lack of connection between pistis and the Lord's Supper, ${ }^{604}$ we now suggest that pistis remains an important element in the praxes of the Christ religion post-baptism, including the Lord's Supper ritual. The motif of pistis can be

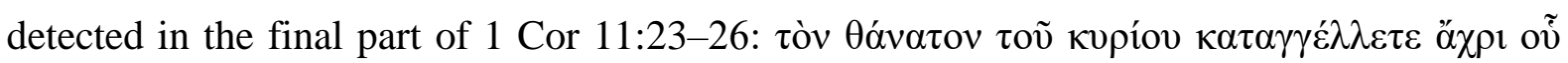

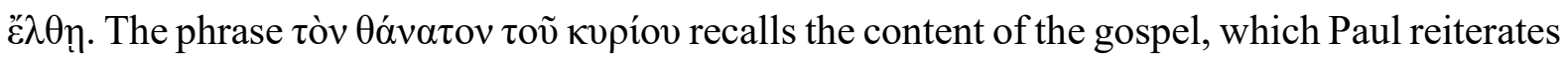

${ }^{604}$ Perhaps the table fellowship incident at Antioch might intimate a connection between the two (Gal 2:11-14) since the debates of pistis in Galatians relates to one's status in Abrahamic covenant. Nevertheless, it is difficult to ascertain that the table fellowship Paul refers to in Gal 2:12 was an actual Lord's Supper or an ordinary fellowship meal. On the other hand, the abuses at the Lord's Supper in the Corinthians indicate that the earliest form of the Lord's Supper is a love feast that would include a meal proper. If this is a case with Antioch incident, then the relationship between pistis and the Lord's Supper could be framed in terms of admission to the table of the Lord's Supper. Nevertheless, we do not have enough evidence apart from this verse to suggest this is the case. 
numerous times throughout the letter (1 Cor $1: 18-31 ; 2: 1-5 ; 3: 10-11 ; 9: 16 ; 15: 1-8) .{ }^{605}$ The

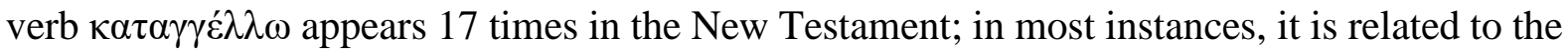
gospel proclamation. ${ }^{606}$ These two observations indicate that the motif of pistis is likely present in the Lord's Supper.

This raises the question of whether this proclaimed pistis is expressed in the acts of celebrating the Lord's Supper or in a verbal proclamation accompanying the ritual. ${ }^{607}$ Although it is highly possible that in the nascent period of the Christ movement, the Lord's Supper ritual was accompanied by an explicit proclamation of the gospel, either in the form of a creedal statement or a reading of Paul's letters, we argue that Paul means that the pistis is proclaimed in the acts of eating bread and drinking from the cup. Granted, $\kappa \alpha \tau \alpha \gamma \gamma \varepsilon \dot{\varepsilon} \lambda \lambda \omega$ normally carries the meaning of verbal pronouncement, but there are some notable exceptions in both biblical and non-biblical texts: ${ }^{608}$

So he who had undertaken to secure tribute for the Romans by the capture of the people of Jerusalem

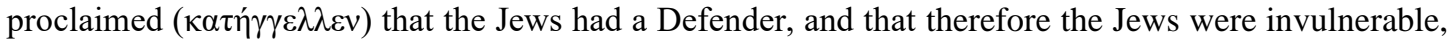
because they followed the laws ordained by him. (2 Macc 8:36)

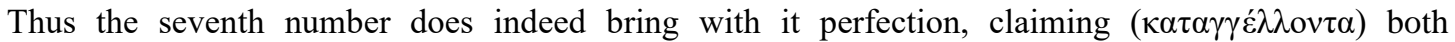
correspondences, that with the superficies by means of the square, in virtue of its kinship with 3 , and that with the solid body by means of the cube, in virtue of its relationship with 4; and 3 and 4 make 7. (Philo, On the Account of World Creation 106).

Far better would it be for a reasonable being if instead of arms, the herald staff, the symbol of treaties of agreement, should spring from the ground, so that it should proclaim ( $\kappa \alpha \tau \alpha \gamma \gamma \varepsilon \dot{\varepsilon} \lambda \lambda \eta \eta)$ peace instead of war to all men everywhere. (Philo, On the Eternal of the World 68)

Jacob was delighted with the dream: grasping in his mind what it predicted and sagely and unerringly divining its import, he rejoiced at the great things that it betokened ( $\alpha \tau \eta \dot{\gamma} \gamma \varepsilon \lambda \lambda \varepsilon \varepsilon$ ), which promised prosperity to his son and that, by the gift of God. (Josephus, Jewish Antiquities 2.15)

For these kine, creatures born to labour at the plough, that thou sawest being devoured by those inferior to them, these ears of corn consumed by lesser ears, alike foretell ( $\pi \rho \alpha_{\alpha} \alpha \alpha \gamma \gamma \varepsilon \dot{\lambda} \lambda$ ovo $\left.\sigma v\right)$ for Egypt famine and dearth for as many years as the period of plenty preceding them. (Josephus, Jewish Antiquities 2.85)

In 2 Maccabees the author narrates the story of Nicanor, an agent of the Seleucid rulers who were defeated under the leadership of the Maccabean family. The context clearly indicates that the defeat and capture of Nicanor constitutes a triumphant proclamation. Discussing the significance of the number seven, Philo of Alexandria writes that it brings perfections by the demonstration of two sorts of correspondences. Philo also criticises myths that depict humans

${ }^{605}$ Contra Gaventa, "You Proclaim the Lord's Death"”; Gaventa thinks that "the death of the Lord" does not refer to the gospel but to the language of crucifixion. However, this is an artificial distinction. The language of crucifixion forms an essential part of the gospel proclamation, and the gospel proclamation includes the language of crucifixion. Thus, Gaventa is splitting hairs on the gospel and its content.

${ }^{606}$ Acts $3: 24 ; 4: 2 ; 13: 5,38 ; 15: 36 ; 16: 17 ; 17: 3,13,23 ; 26: 23$; Rom 1:8; 1 Cor 2:1; 9.14; Phil 1:17, 18; Col 1:28.

${ }^{607}$ Conzelmann, 1 Corinthians, 201.

${ }^{608}$ Gaventa, "“You Proclaim the Lord's Death,"” 381-82. 
with weapons, commenting that it would be far better for humans to carry staffs that herald peace. Finally, Josephus writes of Jacob, who rejoiced at the interpretation of the dream that was demonstrated to him, and of Jacob's interpretation of Pharaoh's dream in which the corn ear proclaims the ensuing famine. These examples should be enough to inform our interpretation of the verb $\kappa \alpha \tau \alpha \gamma \gamma \varepsilon \dot{\lambda} \lambda \lambda \omega$ in 1 Cor 11:26; it does not always denote verbal proclamation; sometimes it refers to a proclamation by deeds.

We turn now to 1 Cor 2:4-5 to learn how this proclaimed pistis is manifested in deeds.

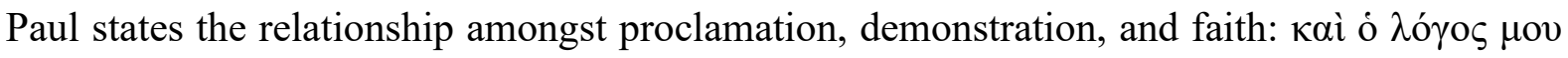

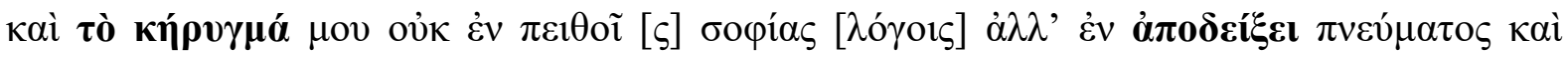

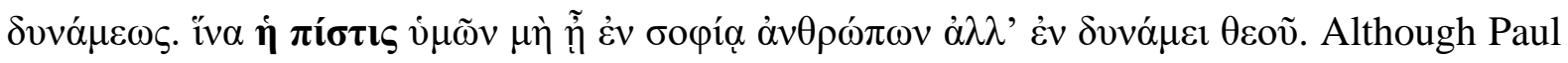

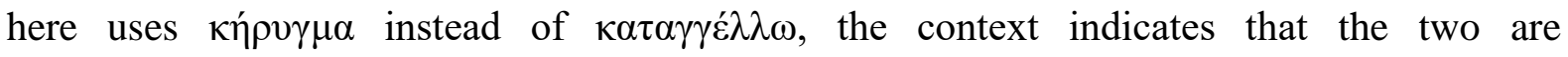
interchangeable, that pistis rests on the proclamation of the gospel that is demonstrated and not merely in words of wisdom. ${ }^{609}$ Note that Paul accents the performative aspect of the proclamation (i.e., $\dot{\alpha} \pi$ ó $\delta \varepsilon \xi \xi \zeta)$ rather than the verbal pronouncement by exposing the emptiness and deceptiveness of human sophistry. One of the occasions to demonstrate this gospel is at

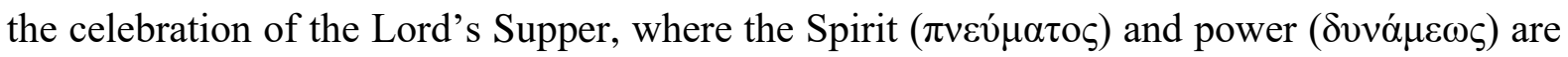
manifest. Here, the Spirit should be taken as referring to God's Spirit, which operates in different capacities amongst the various members of Christ's body who possess the gift of the Spirit. ${ }^{610}$ The $\delta v v \alpha ́ \mu \varepsilon \omega \varsigma$ refers to the performance of miracles of healing, prophesy, or speaking in glossolalia, all of which are likely to take place when the Corinthians are assembled

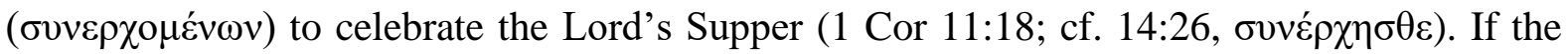

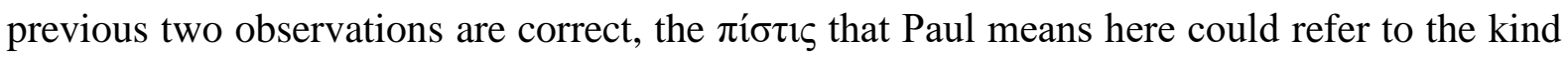
of pistis that is substantiated in the physical performance of the gospel, as manifested in the celebration of a communal meal amongst Christ's body at which self-sacrificing love is shown

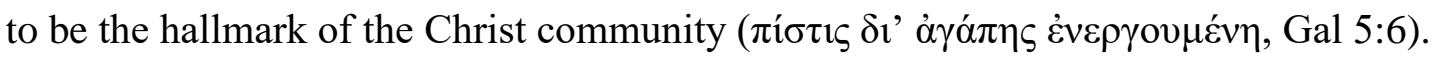

We have demonstrated various ways in which baptism and the Lord's Supper interact with pistis. Baptism incarnates the revelation of pistis, ritually resolves the disunities amongst the body of Christ for the realisation of the gift of pistis therein, ratifies the new covenant in the form of pistis, and becomes the basis for $\dot{\pi} \alpha \kappa o \eta j \pi i ́ \sigma \tau \varepsilon \omega \varsigma$. The Lord's Supper is the physical

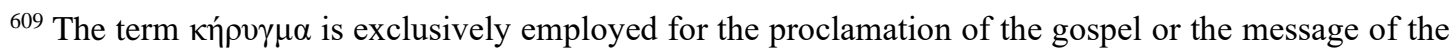
gospel itself, whether preaching (1 Cor 1:21, 15.14; Titus 1:3) or message (1 Cor 2:4).

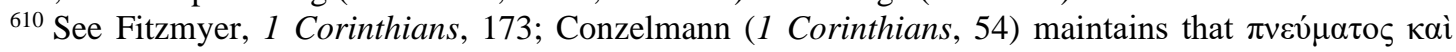
$\delta v v \alpha ́ \mu \varepsilon \omega \varsigma$ should be read as a possessive genitive rather than an objective genitive. 
embodiment of pistis that works through love. In the next section, we examine the roles that pistis and ritual play in union with Christ.

\subsection{The Role of Pistis and Ritual in Union with Christ}

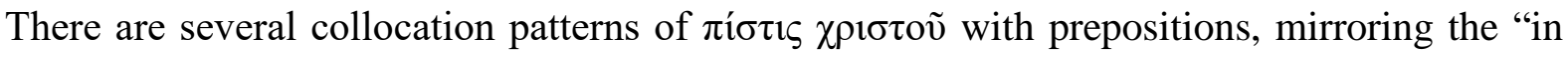

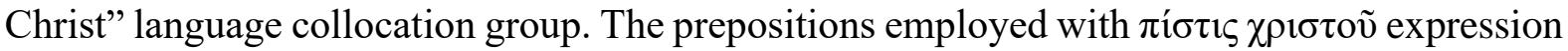
are $\delta i \grave{\alpha}, \dot{\varepsilon} v$, and $\dot{\varepsilon} \kappa .{ }^{611}$ All these constructions but $\dot{\varepsilon} \kappa$ have corresponding constructions with the language of baptism. There is another $\pi i ́ \sigma \tau \iota \varsigma$ construction that denotes the participation notion

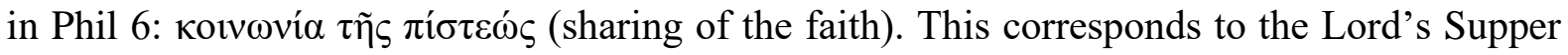

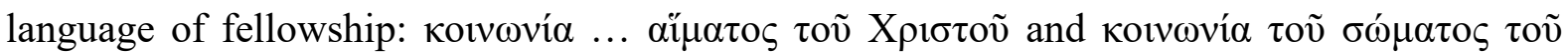

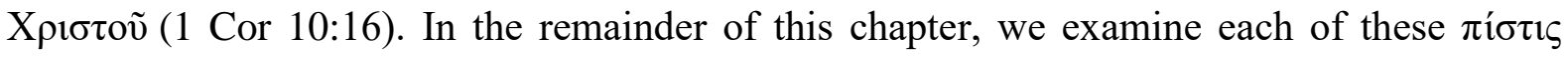
participatory constructions and how they relate to their ritual counterparts.

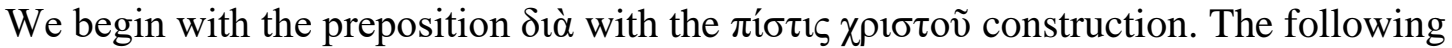
shows the occurrences of the construction, with and without the definite article, in both undisputed and disputed Pauline letters:

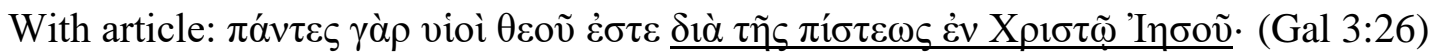

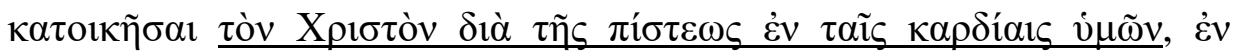

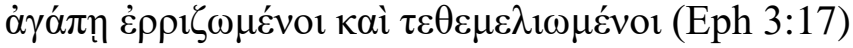

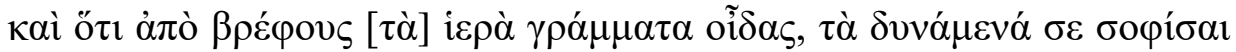

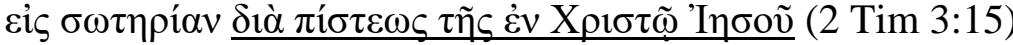

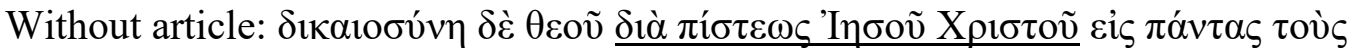

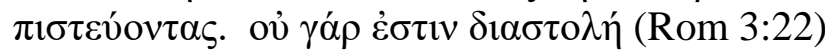

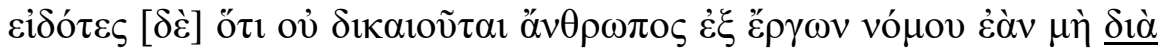

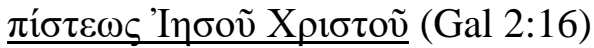

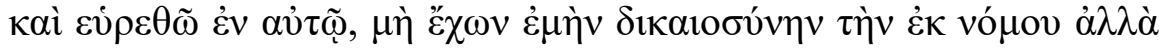

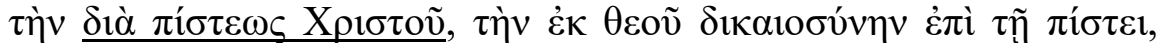
(Phil 3:9)

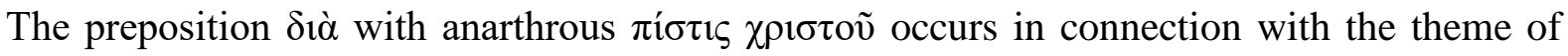

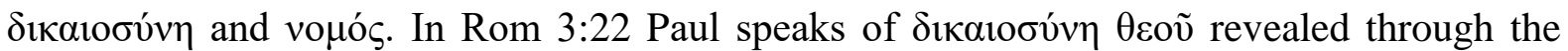

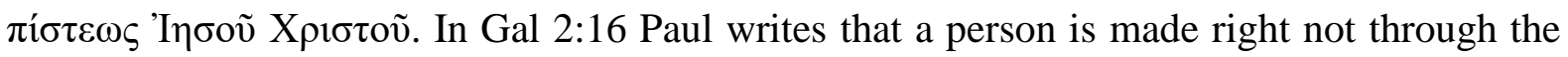

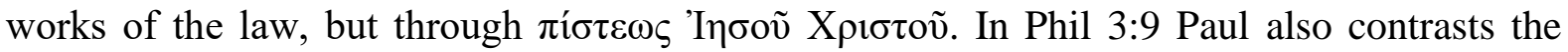

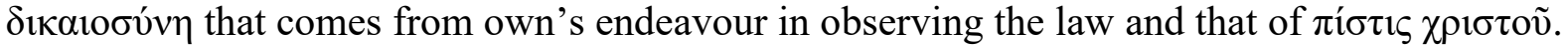

${ }^{611}$ See Arland J. Hultgren, "The Pistis Christou Formulation in Paul.” NovT 22, no. 3 (1980): $248-63$. 


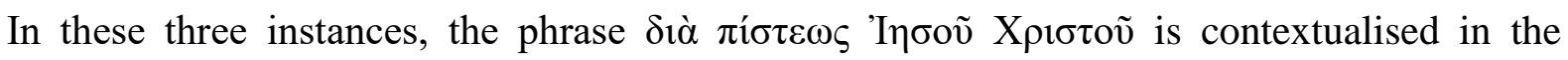

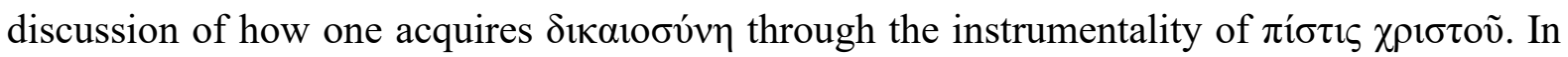

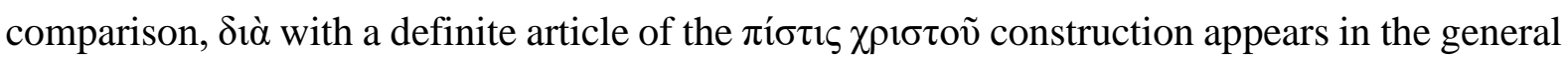
context of soteriology. In Gal 3:26 Paul makes the general remark that all are made children of

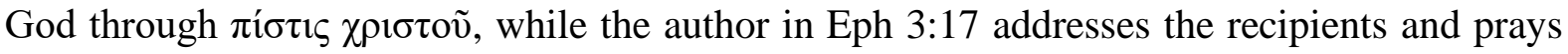
that his readers would have Christ dwell in their hearts through pistis. Finally, in 2 Tim 3:15

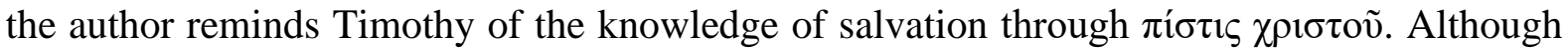
the author does not specify the details of that salvation, the context indicates that this statement is a summary of all that salvation entails.

What accounts for this difference may lie in the perspective that Paul takes when he chooses one or the other forms of phraseology. In the latter, Paul has a global view of salvation,

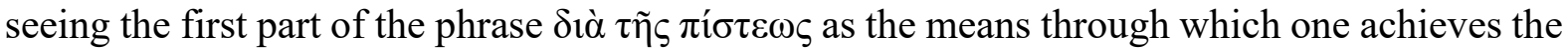

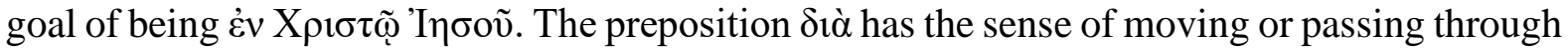
two objects, and by metaphorical extension it implies the means by which passage is obtained. ${ }^{612}$ The preposition $\dot{\varepsilon} v$, on the other hand, has the basic meaning of "in the realm of," presupposing that the movement of the action is finished, and it is in a static state. ${ }^{613}$ Combined

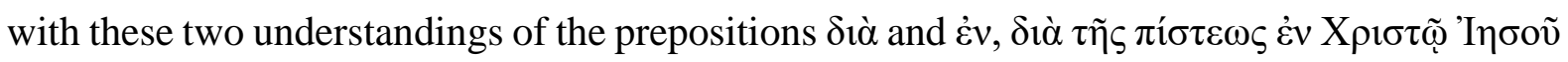
can be interpreted as Paul's shorthand for the whole process of salvation: by means of pistis one is united with Christ. In the case of the abbreviated form of the phraseology, Paul focuses

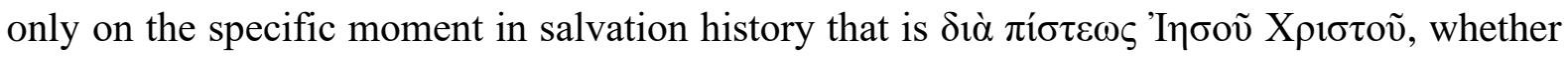
this happens before or continues after baptism. This may well explain Paul's use of $\delta i \alpha ̀$ $\pi \dot{\sigma} \sigma \varepsilon \omega \varsigma$ 'I how one is made righteous before God, which is a specific moment in a person's conversion to

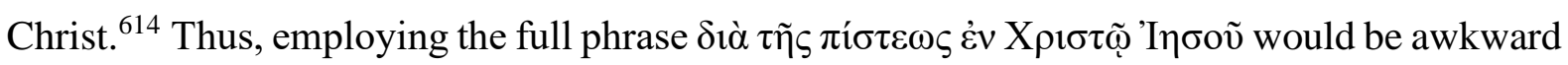
when Paul is writing of one particular moment within the overall scheme of soteriology.

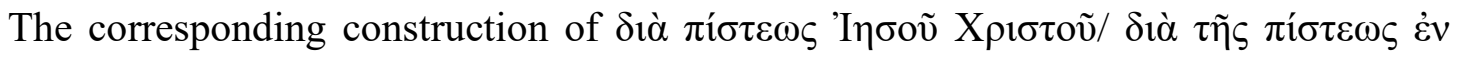

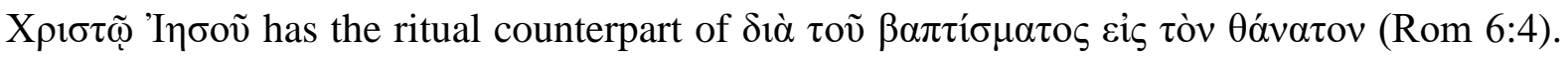
Viewing these two sets of phrases together reveals their parallelism.

612 Porter, Idioms, 148.

613 Ibid., 156.

614 This study adopts the definition of conversion as "a dynamic process based on the crucial interaction between belief and behavior of human beings as well as social mechanisms and narrative identity constructions." Despotis, "From Conversion in Paul and 'John'," 94. 


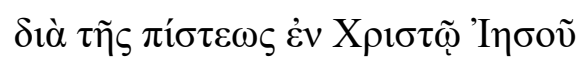

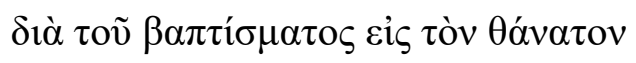

Both share the same preposition $\delta i \alpha$ with a definite article noun, with the "in Christ" language

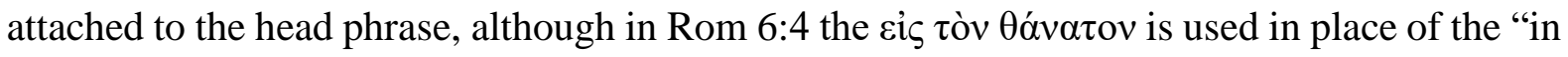
Christ" language. The only variant between the two is $\dot{\varepsilon} v / \varepsilon i s$ with regard to participatory language. Although Harris observes that Hellenistic Greek tends "to confuse the categories of linear motion ('to') and punctiliar rest ('in')," 615 the distinction is still observed amongst the various authors of the New Testament. ${ }^{616}$ Given the subtle distinction between these

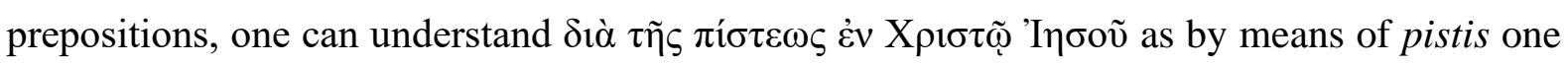

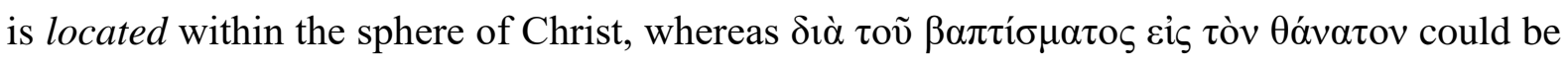
interpreted as by means of baptism one is transferred into Christ's sphere of influence. The latter enunciates the dynamic aspect of participation in Christ, as opposed to the static aspect of the union in the former. These observations reveal that the roles of pistis and baptism in union with Christ are as follows: pistis as an abstract concept is naturally located within the realm of ideas and concepts (signified by $\dot{\varepsilon} v$ ), but it is given a physical embodiment in the ritual of baptism to show the candidates transferring from the profane world to the divine realm (indicated by $\varepsilon i \varsigma) .{ }^{617}$

The most obvious expression that expounds the participatory notion of pistis is the

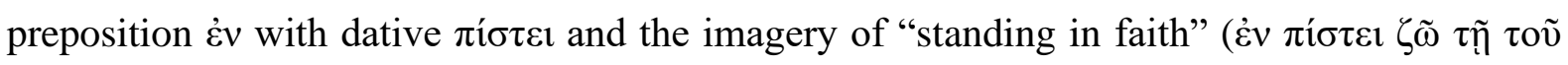

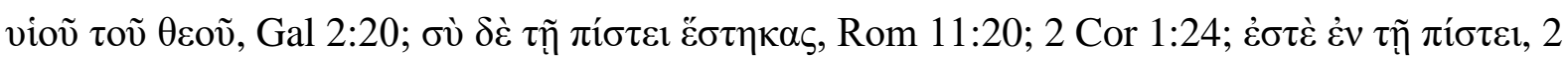
Cor 13:5). Notwithstanding the spatial dynamism embedded in $\dot{\varepsilon} v$, the traditional interpretation tends to privilege the instrumental-causal sense over the spatial sense regarding $\dot{\varepsilon} v \pi i ́ \sigma \tau \varepsilon$. This is reflected in most English translations of the Bible, in which \&̇v $\pi i ́ \sigma \tau \varepsilon \imath$ in Gal 2:20 is rendered as "by faith," as opposed to "in faith" in a handful of translations. ${ }^{618}$ The present study argues that there is ample room to include a spatial-participatory dimension to $\dot{\varepsilon} v \pi i ́ \sigma \tau \varepsilon \mathfrak{l}$ that joins the

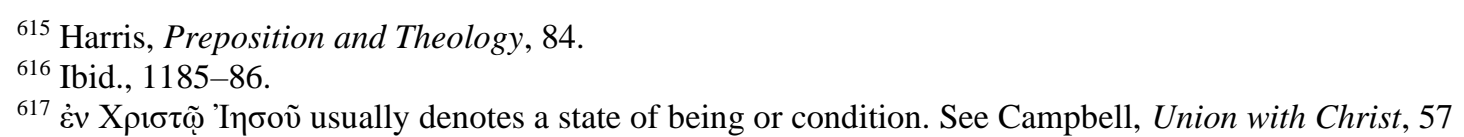

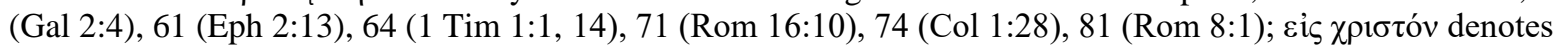
the notion of moving from one state to another (Eph 4:15); see Campbell, Union with Christ, 151-52. 618 "By faith": NRSV; KJV; AMPC; CSB; ESV; CEB; HCSB; NABRE; NIV. "In faith": Young's literal translation, "and that which I now live in the flesh -- in the faith I live of the Son of God, who did love me and did give himself for me"; American Standard Version, "and it is no longer I that live, but Christ liveth in me: and that life which I now live in the flesh I live in faith, the faith which is in the Son of God, who loved me, and gave himself up for me." Bold mine. 
traditional instrumental-causal interpretation. First, the parallelisms in Gal 2:20 make it attractive to read a spatial-participatory dimension in the verse.

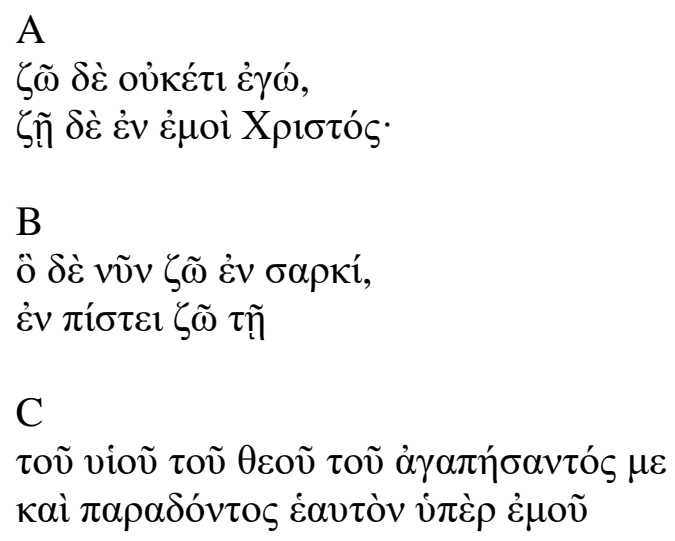

Note that there are three sets of parallelisms in the verse. The first deals with existential parallels: the old self versus the living Christ. The second set compares the sphere of influence under which one lives: $\dot{\varepsilon} v \sigma \alpha \rho \kappa i$ or $\dot{\varepsilon} v \pi \hat{\imath} \sigma \tau \varepsilon$. The last set complements the love of the son of God with his concrete action in delivering himself up to the crucifixion. Thus, given the consistency of the parallelisms that Paul makes, it is plausible to conclude that $\dot{\varepsilon} v \pi \dot{\sigma} \sigma \tau \varepsilon \mathrm{l}$ in B could be rendered "in faith." Second, Paul uses the same language of "standing in faith" to

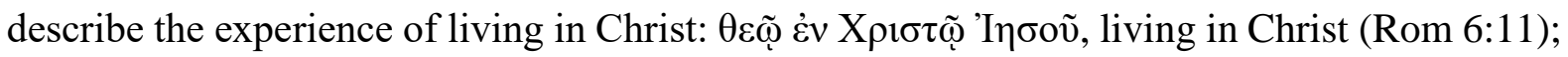

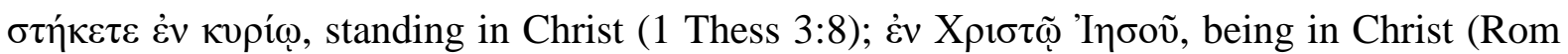
$8: 1 ; 12.5 ; 16: 11 ; 1$ Cor $1: 30 ; 2$ Cor $5: 17,19) .{ }^{619}$ From this, Schliesser concludes that "all of these passages affirm their correspondence between faith and Christ, as both share a core meaning in terms of a Machtbereich into which individuals are incorporated and under whose influence a new communitas is created (cf. Gal. 3:26-28)."620

Having established the participatory dimension of $\dot{\varepsilon} v \pi \hat{\imath} \sigma \tau \varepsilon$, we now compare it with its ritual counterpart: $\varepsilon \dot{\imath} \varsigma$.. غ̇ß $\beta \pi \tau i ́ \sigma \theta \eta \tau \varepsilon$ :

\begin{tabular}{|c|c|}
\hline Ritual & Pistis \\
\hline 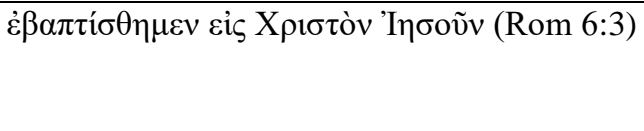 & 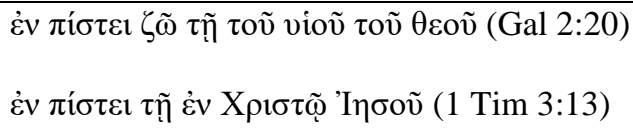 \\
\hline 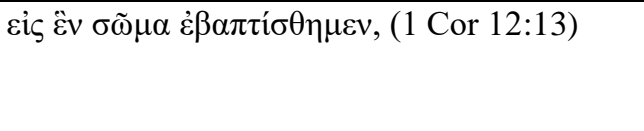 & 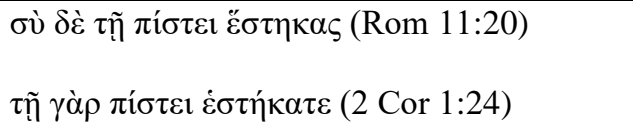 \\
\hline 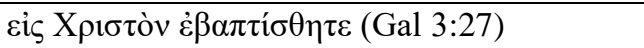 & 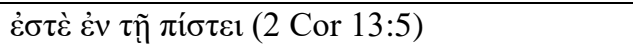 \\
\hline
\end{tabular}

${ }^{619}$ Schliesser, "“Christ-Faith,"” 287.

${ }^{620}$ Ibid., 287. 
Several observations can be made. Staring with the prepositions $\varepsilon \dot{i} \zeta$ and $\dot{\varepsilon} v$, given the subtle distinction between the punctiliar rest and movement into, baptism with घiऽ denotes the action of participation, whereas pistis with $\dot{\varepsilon} v$ denotes the static condition of being in a sphere of

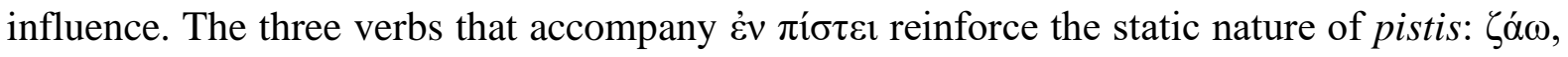

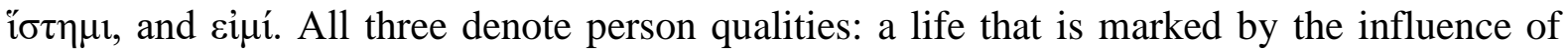
Christ, being steadfast in the pistis, and the state of being in Christ. Each verb modifies the kind of pistis that Paul writes of in a specific context, and none denotes the notion of movement. On the baptism side, the imageries - body, clothing, and sonship - associated with the act of baptism provide a physical embodiment of the qualities embedded in the pistis. The images of body, clothing, and sonship invoke the notion of remaining in these statuses, which have been afforded by that imagery. This corresponds to the static nature of verbs that modify $\dot{\varepsilon} v \pi i ́ \sigma \tau \varepsilon 1$. Finally, the object of the prepositions $\varepsilon i \varsigma$ and $\dot{\varepsilon} v$ is Christ, the goal of union. On the ritual side,

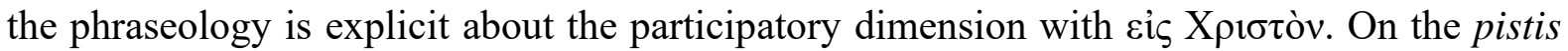
side, the participatory notion is implicit in the phrase $\dot{\varepsilon} v \pi i$ í $\tau \varepsilon$, except for the explicit

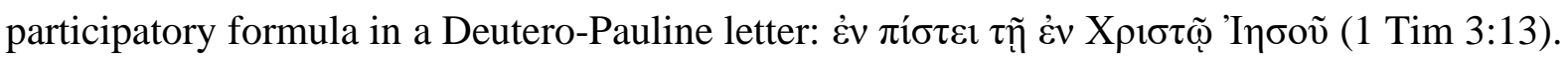
Based on these observations, we can conclude that $\dot{\varepsilon} v \pi i ́ \sigma \tau \varepsilon \mathrm{l}$ is static and abstract, whereas عis ... غ̇ $\beta \alpha \pi \tau i \sigma \theta \eta \tau \varepsilon$ is dynamic and physical. In other words, the latter provides a physical embodiment of the former by ritually transferring the candidates into Christ's sphere, in which they reside.

At first glance, the preposition $\dot{\varepsilon} \kappa$ with pistis does not appear to suggest a participatory notion; however, upon closer inspection $\dot{\varepsilon} \kappa \pi \dot{\sigma} \sigma \tau \varepsilon \omega \varsigma$ is a variant of $\dot{\varepsilon} v \pi \dot{i} \sigma \tau \varepsilon 1$, since it is "clearly and explicitly derived from Habakkuk 2:4,"621 whose Hebrew counterpart would have been ב ב ב having a partisan sense. ${ }^{622}$ Paul might well be aware of Semitic influences of the LXX translation regarding Hebrew min, as some מ̣ texts were rendered with ع̇v (Exod 16:27; Ruth 2:20; 1 Sam 9:3; 2 Kgs 10:3). ${ }^{623}$ Furthermore, Schließer observes that "Aquila reads $\varepsilon v$ $\pi i ́ \sigma \tau \varepsilon 1$, Symmachus has $\tau \tilde{\eta}$... $\pi i ́ \sigma \tau \varepsilon 1$, and the even earlier Greek fragments of Habakkuk found

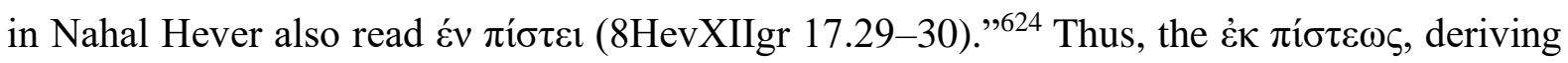
from the LXX citation of Hab 2.4, could well be a variant of $\dot{\varepsilon} v \pi i ́ \sigma \tau \varepsilon 1$.

\footnotetext{
${ }^{621}$ Watson, "By Faith (of Faith)," 149.

${ }^{622}$ Schliesser, "“Christ-Faith," 288.

${ }^{623}$ Garlington, "Paul's 'Partisan Eк,'” 568-70.

${ }^{624}$ Schliesser, "“Christ-Faith,"” 288.
} 


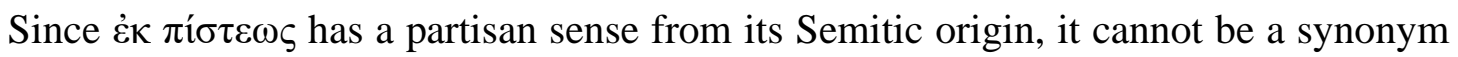
for $\delta i \grave{\alpha} \pi i ́ \sigma \tau \varepsilon \omega \varsigma$, as D. A. Campbell and others have attempted to maintain. ${ }^{625}$ Campbell rightly points out the flaws in Stanley Stowers's arguments supporting a distinct meaning between $\dot{\varepsilon} \kappa$

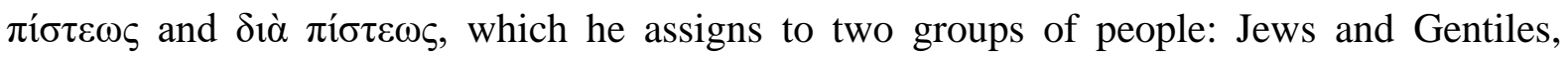

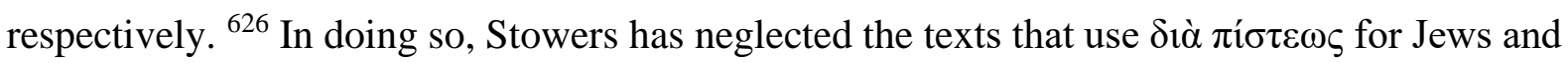

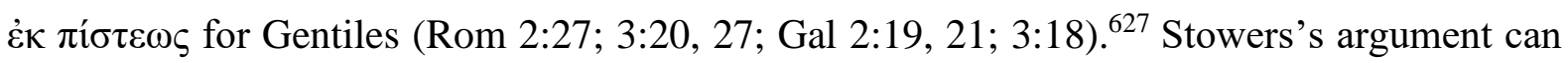
be redeemed by turning to the subtle distinction between $\delta$ ì and $\dot{\varepsilon} \kappa$. By applying these different meanings into the texts that Campbell thinks are used interchangeably, we see the following results:

Gal 2:16 Yet we know that a person is justified not by the works of the law but by means of faith ( $\delta i \grave{\alpha} \pi i ́ \sigma \tau \varepsilon \omega \zeta)$ in Jesus Christ. And we have come to believe in Christ

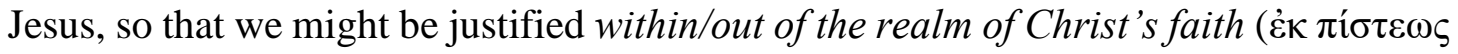

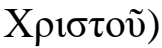

Gal 3:22 But the scripture has imprisoned all things under the power of sin, so that what

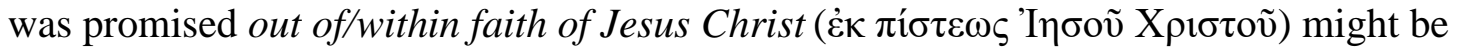
given to those who believe.

Gal 3:24 Therefore the law was our disciplinarian until Christ came, so that we might

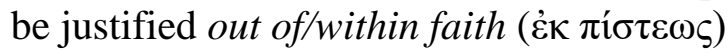

Gal 3:26 For in Christ Jesus you are all children of God by means of faith ( $\delta i \grave{\alpha} \tau \tilde{\eta} \varsigma$ $\pi i ́ \sigma \tau \varepsilon \omega \varsigma)$

These renderings show that Paul consciously chooses his prepositions by bringing out a specific shade of meaning in his writings. In Gal 2:16a Paul contrasts the Law and faith as two means

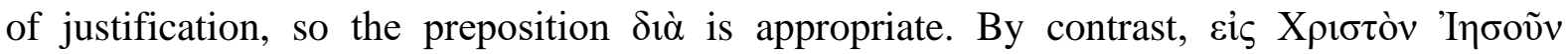

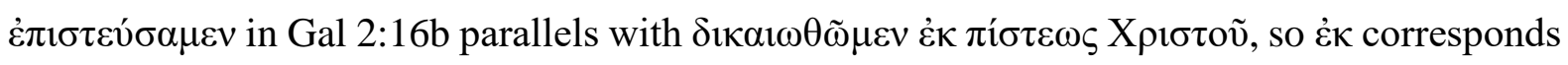

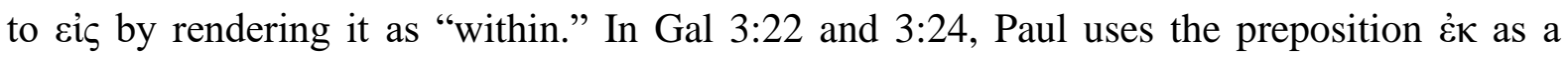
continuation of the thought running from the opening chapter on the theme of Abraham's

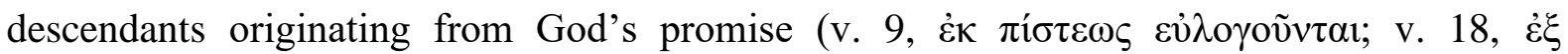

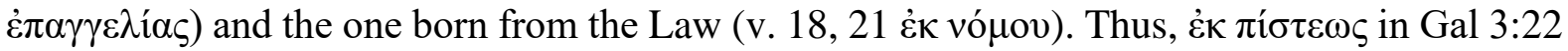
and v. 24 completes the line of thought developed in the previous section on the topic of Abraham's lineage. In Gal 3:26, meanwhile, Paul turns his attention to the ramifications that

${ }^{625}$ Douglas A. Campbell, "The Meaning of Pistis and Nomos in Paul: A Linguistic and Structural Perspective," JBL 111, no. 1 (1992): 91-103; Schliesser, "“Christ-Faith,"” 288; and Watson, "By Faith (of Faith)," 149n6.

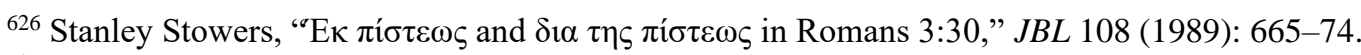

${ }^{627}$ Campbell, "The Meaning of Pistis," 93-94n9. 
this seed of Abraham has had on his readers; that is, they have been adopted as God's children by means of this heir of promise ( $\delta \grave{\imath} \tau \tilde{\eta} \varsigma \pi i ́ \sigma \tau \varepsilon \omega \varsigma)$. In conclusion, Paul is deliberate in his usage of prepositions to denote a specific nuance.

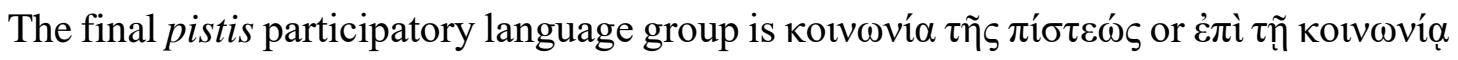

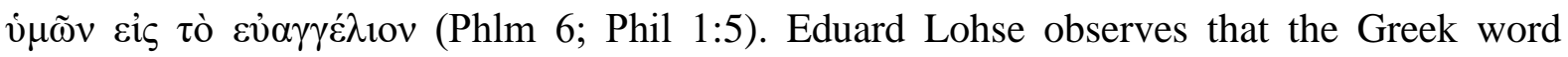

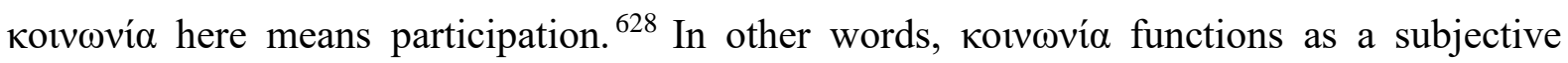
genitive to $\pi \dot{i} \sigma \varepsilon \varepsilon \omega ́ \varsigma$ as "participation of faith." This is the preferred reading, because Paul

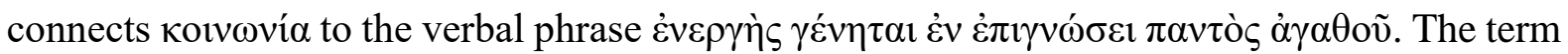
$\pi \alpha v \tau$ ò $\zeta$ $\gamma \alpha \theta$ oṽ refers to God's works in Paul's listeners of his gospel proclamation (Rom 10:15; Phil 1:6; cf. Rom 8:28), and to Paul's admonition to his readers to pursue good works (Rom 15:2; Gal 6:10; 1 Thess 5:15). ${ }^{629}$ Therefore, Paul adds a corporate dimension to $\pi i ́ \sigma \tau \varepsilon \omega ́ \varsigma$ by

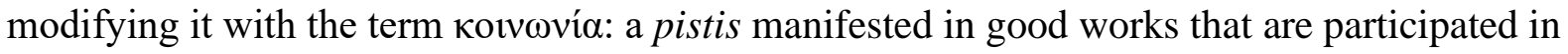
by all members of the body of Christ. ${ }^{630}$

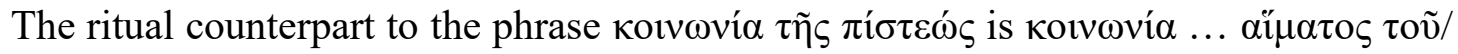

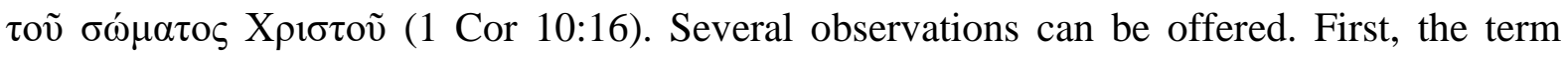

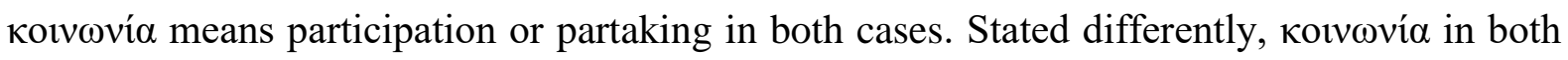
pistis and ritual context denotes action or activity, rather than a state of being. Second, the point

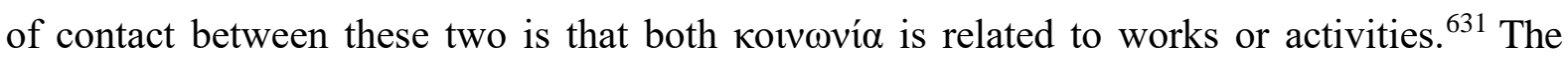

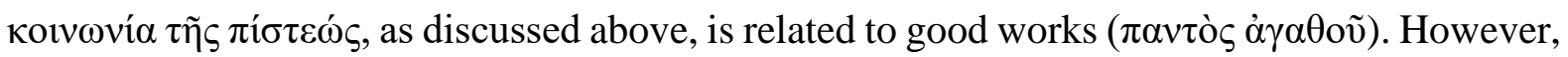
it could also relate to the term $\lambda \varepsilon i \tau o v \rho \gamma i \alpha$, which is rendered as service or ministry ( 2 Cor 9:12; Phil 2:30; Heb 8:6; cf. Luke 1:23). Like the term $\pi \alpha v \tau$ ò $\varsigma$ $\alpha \gamma \alpha \theta$ oṽ, the context in which $\lambda \varepsilon \imath \tau o v \rho \gamma i \alpha$ appears presupposes a self-sacrificing spirit on the part of the one performing the $\lambda \varepsilon ı \tau o v \rho \gamma i ́ \alpha$ : financial donation to the Jerusalem community as a voluntary gift, or risking one's

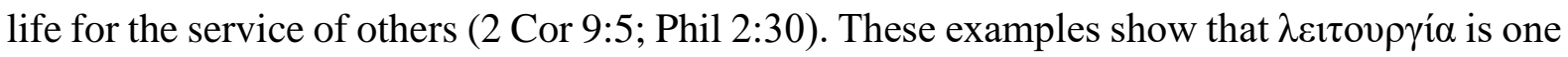

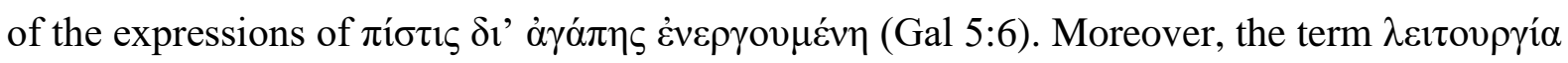
is also related to matters of worship and offering on other occasions (Heb 9:21; Phil 2:17). It seems that the line between formal worship and acts of charity are blurred or, rather, that the spiritualisation of ritual acts in good works can already be discerned in Paul's letter to the Romans: "I appeal to you therefore, brothers and sisters, by the mercies of God, to present your

\footnotetext{
${ }^{628}$ Eduard Lohse, A Commentary on the Epistles to the Colossians and to Philemon, trans. William R. Poehlmann and Robert J. Karris (Philadelphia, Fortress Press, 1971), 193; cf. Heinrich Seesemann, Der Begriff KOINQNIA Im Neuen Testament, BZNW 14 (Giessen: Alfred Töpelman, 1933), 79-83.

${ }^{629}$ Lohse, Commentary on the Epistles, 194.

${ }^{630}$ Cf. Chrysos, Hom. Phlm. 2: "If thou art a partaker, he says, with respect to the faith, thou oughtest to communicate also with respect to other things."

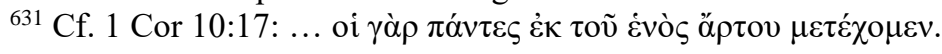


bodies as a living sacrifice ( $\theta v \sigma i ́ \alpha v \zeta \tilde{\omega} \sigma \alpha v)$, holy and acceptable to God, which is your spiritual

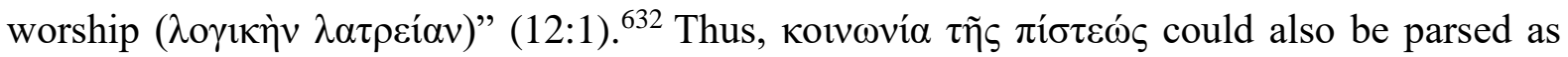

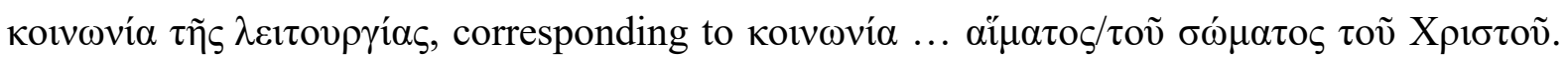
Finally, if these observations are correct, we have here a perfect alignment between pistis and the Lord's Supper: the sharing of pistis that is manifested in good works and services finds its ultimate expression in the celebration of the communal meal whose acts of sharing bread and wine is the physical embodiment of sharing pistis, and this sharing of pistis includes services outside of formal worship, which is also deemed a spiritual act of worship.

\subsection{Conclusion}

This chapter has examined the relation between pistis and ritual and their roles in union with Christ. The study first establishes the term pistis as multi-dimensional - encompassing intellectual, dispositional, and performative aspects - and then re-configures baptism and the Lord's Supper in anthropological terms (i.e., rituals), not theological terms (i.e., sacraments). Then, the study examined various ways in which baptism and the Lord's Supper embody the abstract concept of pistis in the physical world - how pistis becomes "real" in the ritual

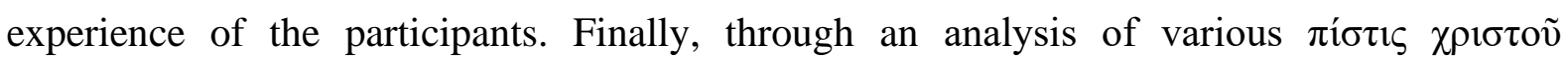
expressions ( $\delta i \grave{\alpha}, \dot{\varepsilon} v$, and $\dot{\varepsilon} \kappa)$ and corresponding expressions relating to baptism and the Lord's Supper, the study has shown that pistis and ritual are complementary in the union with Christ: abstract and static characterize the nature of pistis, ${ }^{633}$ whereas physical and dynamic are the essence of ritual performance. Based on the results of this study, the theological impasse that has so often characterised the debates surrounding faith and baptism (sacraments) can be overcome.

${ }^{632}$ See Stephen Finlan, "Spiritualization of Sacrifice," SEA 78 (2013): 57-86.

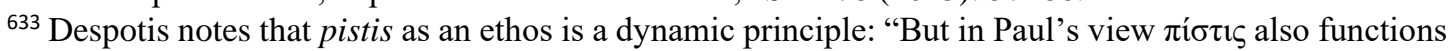
as an ethos which corresponds to the believer's sharing in Christ's death and the power of his resurrection (Phil 3:10-11). This faith is neither an abstract ideal nor an individual matter in Paul. It involves collective and individual, cognitive, psychological and moral elements. ... [it] has a dynamic character, in a sense that it is vital (Gal 5:6), grows in the human being [(2 Cor 8:7, 10:15, though it also can remain uncompleted (1 Thess 3:10)] and humans can gradually recognise more insights of faith (Phlm 9)." "Beyond Theological Argument: The Ethics of Love and Coming to Faith in Paul," in Participation, Justification, and Conversion: Eastern Orthodox Interpretation of Paul and the Debate Between "Old and New Perspectives on Paul", edited by Athanasios Despotis. WUNT II 442 (Tübingen: Mohr Siebeck. 2017), 353-54. In our discussion, we have delineated three aspects of pistis and one of them being dispositional aspect, to which Despotis' definition of pistis belongs. Thus, pistis defined in this way is dynamic. However, we reach the conclusion that pistis is abstract and static insofar as

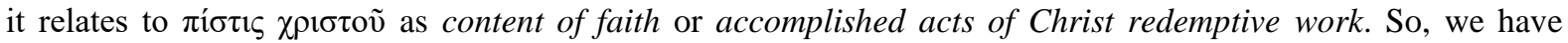
demonstrated that how pistis in such narrow sense is made real and concretised in the materiality of ritual performance. 


\section{Chapter 6 \\ The Ritual Dimension of Union with Christ in Paul's Thought: Divine-Human Relation}

\subsection{Introduction}

In this final chapter, we provide an overview of the arguments made in the previous chapters, organising them into a series of points in a logical order. We will also synthesise the arguments made that are otherwise dispersed throughout the chapters. Then, we answer the three research questions posed at the outset of this study before discussing the significance of this work in the current terrain of biblical scholarship and possible new lines of inquiry. Finally, we conclude the study with a final reflection on the work as a whole.

\subsection{Recapitulation of the Argument}

The central claim of this thesis is that, for Paul, baptism and the Lord's Supper affect union with Christ. In support of this, this study has developed an argument in the following manner:

1. That baptism and the Lord's Supper references in Paul are ritual references, not mere metaphors.

2. That baptism and the Lord's Supper are closely linked with the notion of participation in Christ.

3. That pistis (as referring to $\pi i ́ \sigma \tau ı \varsigma \chi \rho ı \tau \tau o \tilde{v}$ ) is an abstract concept that is substantiated in the material forms of ritual and ritual performance.

4. That baptism and the Lord's Supper rituals facilitate union with Christ, resulting in a transfigured divine-human relation.

These points are developed concomitantly throughout the chapters. Drawing these ideas together, we now synthesise them under these four points to recapitulate the main argument.

We begin with the issue of the nature of the baptismal and eucharistic passages in Paul's letters. Many have approached these texts as theological discourses. By contrast, this study argues that this is not the best characterisation of these texts. Rather, they reflect one of the earliest ritual practices of the nascent Christ religion. In support, we provide three lines of evidence - the baptism tradition, performative indicators, and metaphor predication - to argue that these baptismal passages are indeed ritual references and further demonstrate the connection between the institution narrative and the eucharistic references in 1 Cor 10:16-17. The evidence for the ritual text of these baptismal passages is as follows: 
1. Indicators of baptism tradition: Three criteria were used to isolate the baptism tradition contained in these passages. First, a sudden switch in personal pronouns signifies a break in the flow of thought in the passage: a change from third-person singular to the firstperson plural in 1 Cor 12:13, and a change from the first-person plural in Gal 3:25 ( $\dot{\varepsilon} \sigma \mu \varepsilon v)$ to second-person plural in the tradition ( $\dot{v} \mu \varepsilon i \bar{\varsigma})$ in $3: 27-28$. Second, the highly exalted and poetic religious language indicates a religious ceremony or rite. In 1 Cor 12:13, the exalted language of "Proklamation der Einheit der Gemeinde" indicates a technical religious speech used during the baptism. In 1 Cor 6:11, Paul's reference to "the name of the Lord Jesus Christ" suggests a cultic activity: the name of Jesus is invoked at baptism. Lastly, the same set of phrases occurs several times throughout the Pauline corpus. For example, the verb $\dot{\alpha} \pi \circ \lambda \circ v i \varepsilon \sigma \theta \alpha$ in 1 Cor 6:11, which has been observed as special baptismal language drawing on the cultic-liturgical tradition, also appears in Acts 22:16. The sequence of the phrase with $\dot{\alpha} \lambda \lambda \dot{\alpha}$ construction in 1 Cor 6:11, which stands out from the context, is regarded as a tradition; the three contrasting pairs in Gal 3:28 (Jew/Greek, slave/free, male/female), which also appear in 1 Cor 7:18-22, 12:13; Col 3:11, and John 17:21 attest to the prevalence of the tradition in the early Christ

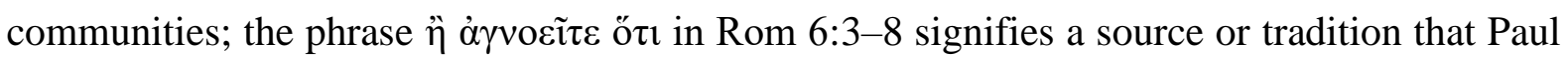
appeals to in the verses that follow and occurs throughout Paul's writings.

2. Performative indicators: In 1 Cor $12: 13$, the verb $\dot{\varepsilon} \beta \alpha \pi \tau i \sigma \theta \eta \mu \varepsilon v$ in the aorist tense

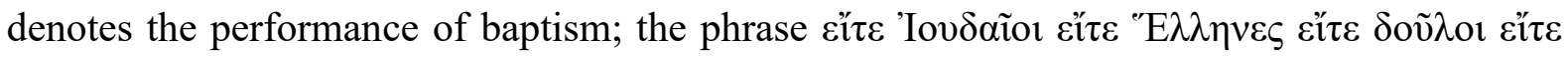

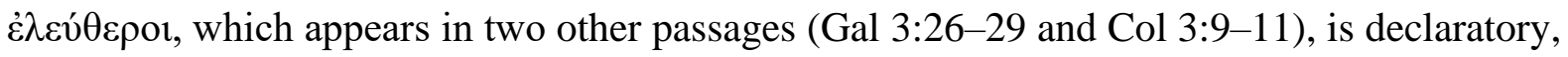

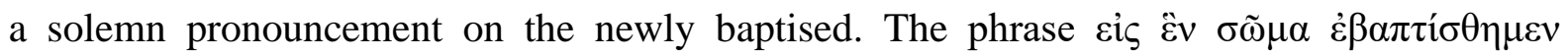
indicates that, by undergoing the baptism ritual, the candidate fully accepts the worldview and symbolic message encoded therein through the indexical gesture of immersion and emersion.

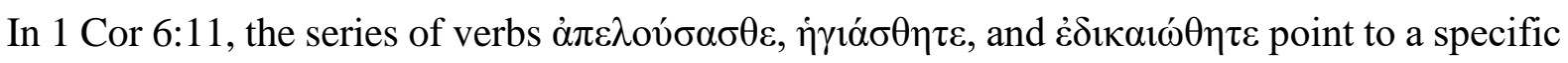
act in the past that is foundational to the current status of the Corinthians before God; the verb $\dot{\alpha} \pi \mathrm{o} \lambda$ ov́ $\omega$ denotes the cleansing of bodily filth, involving bodily relation to the ritual, while the

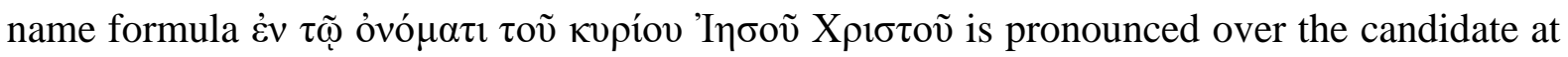

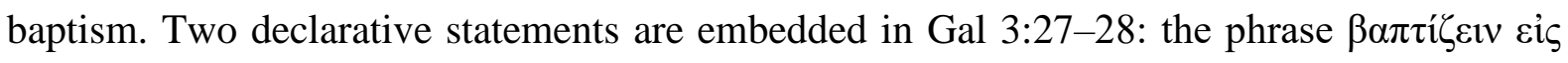

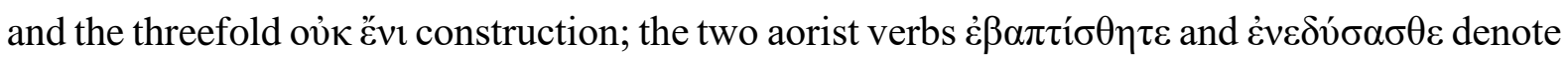
baptismal performance. Finally, in Rom 6:3-8, the verbs $\dot{\varepsilon} \beta \alpha \pi \tau i \sigma \theta \eta \mu \varepsilon v$ and $\eta \gamma \dot{\varepsilon} \rho \theta \eta$ signify the performance of baptism in immersion and emersion; the bodily relation to the ritual is deduced from the $\sigma v v$-compounds ( $\sigma v v \varepsilon \tau \alpha \dot{\varphi} \eta \mu \varepsilon v, ~ \sigma u ́ \mu \varphi v \tau o r$, and $\sigma v v \varepsilon \sigma \tau \alpha v \rho \omega ́ \theta \eta)$. 
3. Metaphor predications: Metaphors in the ritual are a series of ritual scenes that are enacted in the ritual performance. The following are the ritual scenes enacted in both the baptism and Lord's Supper rituals: Christ's body, Spirit, washing ablution, clothing, and the metaphorical images of Christ's death, burial, and resurrection.

The evidence for the eucharistic practice of the institution narrative vis-à-vis the Lord's Supper ritual reference in 1 Cor 10:16-17 is as follows: the basic ritual action of blessing the bread and cup remain the same throughout all the eucharistic accounts (1 Cor 10:16-17; Luke 22:1719 (Western Text); Did. 9.2-3; 1 Cor 11:24-25; Mark 14:22-24; Matt 26:26-28); common

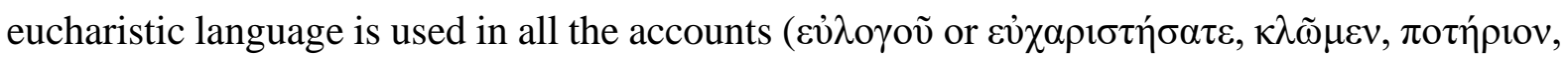
and ó $\rho \tau o v)$; and all these eucharistic accounts have an eschatological emphasis, which is

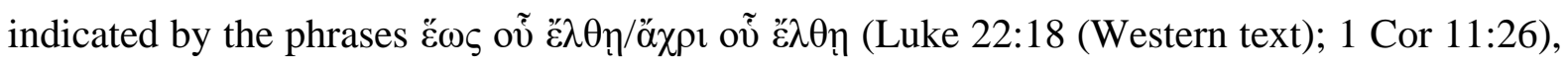

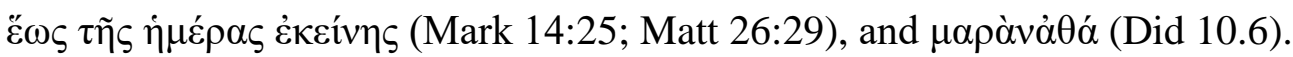

The connection between 1 Cor 10:16-17 and 1 Cor 11:23-26 can be established through three means. The first is contextual clues; the institution narrative cited in 1 Cor 11 belongs to the wider context of discussion on the ordo of worship in the Corinthian community. The second involves the isolation of performance elements: the double commands of $\tau$ oṽ $\tau$ o $\pi$ oteĩ $\varepsilon$

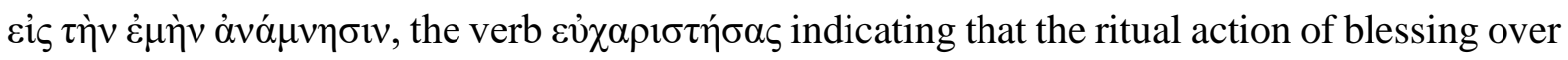
the bread and wine is a form of thanksgiving, and the phrase $\tau$ ò $\dot{v} \pi \dot{\varepsilon} \rho$ v $\mu \tilde{\omega} v$ indicating the interpretation of the tradition by Paul himself. The third is the pattern of creating a new foundational story performed in ritual.

The evidence cited above demonstrates that the passages containing references to baptism and the Lord's Supper do indeed reflect the earliest ritual practices of nascent Christ communities.

Having established the set of ritual texts to be considered for analysis, we also needed to establish whether these two rituals are related to the notion of participation in Christ. To that end, we have established the relationship between rituals and the notion of union with Christ through syntactical analysis that revealed that the ritual language and the participatory idiom

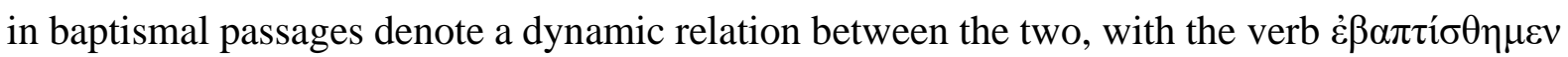

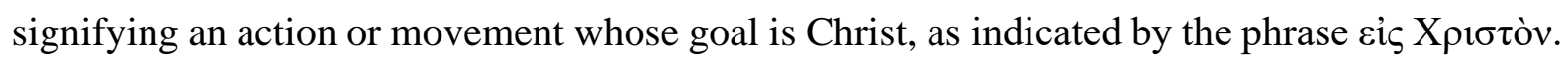
The relation between the ritual language of the Lord's Supper and that of "in Christ" language, on the other hand, evinces a static aspect of participation in Christ, indicated by the copula verb

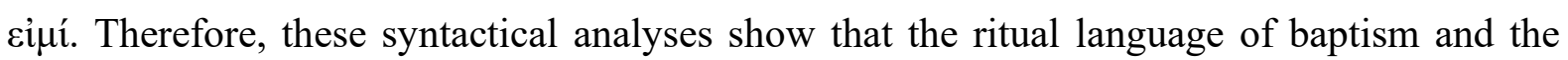
Lord's Supper are linked with “in Christ” language. 
With the demonstration of the link between rituals and "in Christ" language, we employed the ritual transformation model to interrogate the reality of ritual practice. To begin, we identified the passive form of $\beta \alpha \pi \tau i \zeta \varepsilon \sigma \theta \alpha \mathrm{l}$ in these texts to indicate the passive role the pneuma plays as a special agent at the baptism and the first-person plural form of the verbs $\varepsilon \bar{c} \lambda \alpha \varepsilon v$ and $\varepsilon \kappa \lambda \alpha \sigma \varepsilon v$ reveals the active role the celebrant plays in the Lord's Supper ritual. Proceeding to entailments of the ritual, we isolated $\sigma v v$ compound verbs and the technical verbs $\pi \alpha \rho \varepsilon \dot{\lambda} \alpha \beta \beta_{0}$ and $\pi \alpha \rho \varepsilon ́ \delta \omega \kappa \alpha$ as linguistic markers for the entailment of the myths that are enacted in the ritual performance. Then, the ritual performance culminates in the transformation of the participants through these myths, by transferring them into a metaphysical world of imagination from the profane world. This was shown by the preposition cis and the eỉ $\mu$ í + Kowvovía construction. Emerging from the ritual performance, the participants are expected to take up the realities of ritual symbolisms that are infused therein: clothing ( $\dot{\varepsilon} v \delta v ́ \omega)$, divine

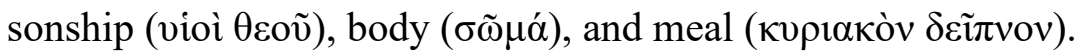

Before proceeding to the ritual analysis of baptism and the Lord's Supper in terms of union with Christ, the role played by pistis in union with Christ had to be addressed, since some have argued that it is pistis - rather than external rites - that unites one to Christ. Using Rappaport's concept that the corporeal representation of ritual acts and gestures brings about the reality of ritual performance, this study has shown that baptism and the Lord's Supper embody, materialise, and create the reality of pistis in physical form. Both unite the participants with Christ, although there is the difference that pistis is the abstract concept (i.e., the mental grasp of faith), whereas the rituals are the physical embodiment of pistis in concrete form.

The pistis formulae that we examined denote the notion of participation in Christ: $\delta$ ì

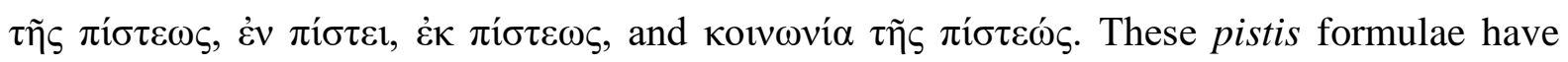

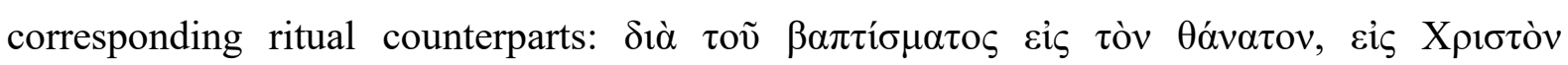

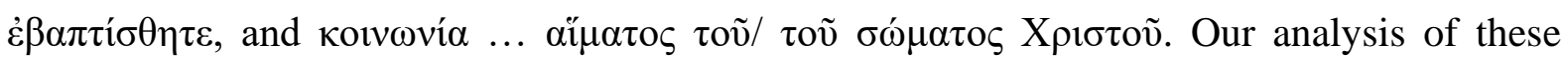
formulae show, regarding pistis and baptism, that the former is static and abstract and finds its physical embodiment and dynamism in the ritual act of baptism; regarding pistis and the Lord's

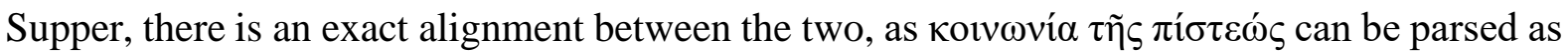

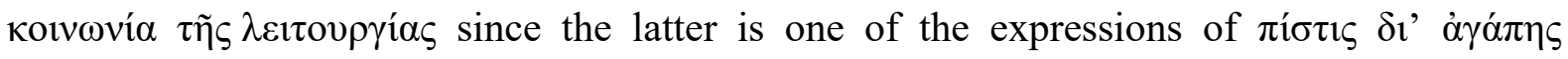

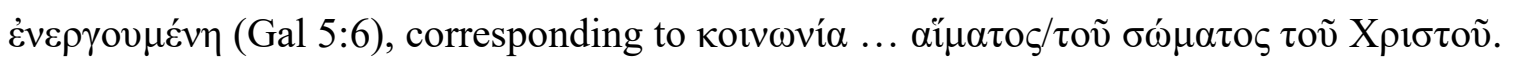

There are several ways in which pistis interacts with baptism and the Lord's Supper. Baptism incarnates the advent of pistis (i.e., the Christ event) which grafts the participants into the Abrahamic lineage ( $\mathrm{Gal} 3$ ), ritually resolves the disunities amongst the body of Christ for the realisation of the gift of pistis therein (1 Cor 12), ratifies the new covenant in the form of 


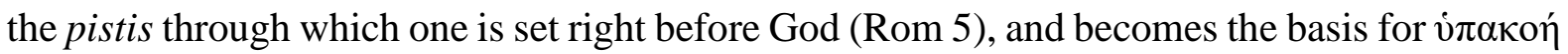
$\pi i ́ \sigma \tau \varepsilon \omega \varsigma$, to whose authority the participants submit (Rom 6:16). The Lord's Supper, by its

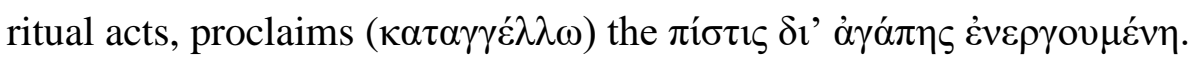

The content of pistis has been substantiated in each aspect of the ritual form that this study has isolated for both baptism and the Lord's Supper; that content appears in the ritual actions of those two rites. The acts of water immersion, doffing and donning on clothing, ecstatic speech, and professing the faith demonstrate the Christ event. The blessing ( $\varepsilon \dot{\chi} \chi \alpha \rho 1 \sigma \tau \eta ́ \sigma \alpha \varsigma$ ) of the bread and wine, the acts of consuming the bread and wine, indicated by the verbs $\varphi \alpha \gamma \varepsilon \tilde{i} v, \pi i v \eta \tau \varepsilon$, and $\delta \varepsilon 1 \pi v \tilde{\eta} \sigma \alpha$, and the proclamation ( $\kappa \alpha \tau \alpha \gamma \gamma \varepsilon \dot{\varepsilon} \lambda \lambda \omega)$ of the death of the Lord realise the pistis worked through love at the Lord's Supper. The ritual actors re-enact the role of a special agent in the script of pistis. These agents are the Spirit, Jesus, and human participants. The times and places provide a ritual environment onto which the physical movements of ritual actions project its organising schemes, and these schemes are reappropriated by the participants as the nature of reality. ${ }^{634}$ The physical movements in baptism and the Lord's Supper rituals transfer the participants into a Christ sphere, outside the structure of worldly time and space. In this ritual environment, the participants engage intimately with the reality of pistis for the transformation of their selves. The ritual objects are the physical objects with which the reality of pistis is created: water, candles, chrism, and garment for the baptism ritual; food and drink for the Lord's Supper. The ritual languages are the verbal aspect of pistis in the forms of the Christ myth, baptismal formulae, ecstatic speech, kerygma, the invocation of Jesus's name and the word maranatha, and scripture readings. Finally, the demographics of the ritual participants relate to the newly formed ritual group whose orientation to life has been transfigured according to the new reality of pistis. In both the baptism and the Lord's Supper rituals, the participants comprised Jewish and Greek, free and slave, and male and female; they gain a new orientation to life whose values subvert the political and cultural norms they inhabit. Having established all the previous points on the suitability of baptismal and eucharistic texts for a ritual analysis, the relation between ritual and the notion of union with Christ, and the role of pistis vis-à-vis ritual, we are now able to execute a ritual analysis on the texts in question, using the ritual transformation model developed for this study. That model consists of the following elements: agency, entailments, transformation, and relationality. This matrix of ritual theories can inform our understanding of the way union with Christ takes place, described in narrative succession.

\footnotetext{
${ }^{634}$ Bell, Ritual Theory, 76.
} 
1. Agency: As per Lawson and McCauley's theory on religious rituals, there are two principles underlying the involvement of a superhuman agent in a ritual: the character of that superhuman involvement and the immediacy thereof. Regarding baptism, this study identified the Spirit as a special agent involved in the administration of the rite, albeit as an enabler of the

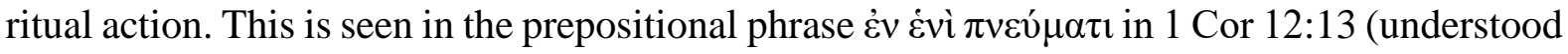
in its instrumental sense) as an object dative of the verb $\dot{\varepsilon} \beta \alpha \pi \tau i \sigma \theta \eta \mu \varepsilon v$. The character of the Spirit's involvement is to complement the baptism ritual by infusing the effects of baptism into the participants. The Lord's Supper, on the other hand, has a direct special agent, Jesus himself, the founder of the cultic practice, as is indicated by the use of first-person pronouns to connect

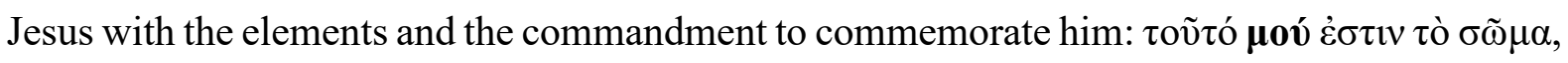

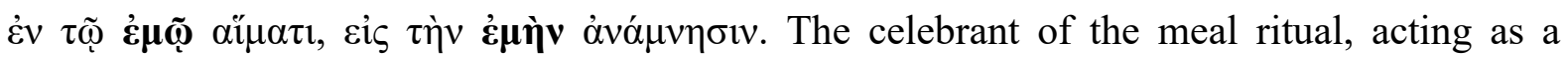
representative of the special agent, is likely the paterfamilias who acts as a host to the community and takes the lead in showing self-sacrificial love through the act of distributing food and drink in the meal.

2. Entailments: Myth and sanctity are entailed in the ritual structures of baptism and the Lord's Supper. After analysing both rites, we have suggested that the myth of creation and recreation underlie both. Concerning baptism, the link to the creation myth of Adam can be found in Rom 5, which immediately precedes Rom 6, where Paul expounds on the implications of a new life in Christ through baptism. Since Rom 5 is logically connected to Rom 6, Paul connects the creation myth of Adam with that of the Christ event by drawing parallels between the two as prototypes of the respective dominions of the old and new eras. Concerning the Lord's Supper, the connection to the creation myth is made possible by Paul's framing of the meal practice in the context of the Passover meal. Just as Moses instituted that feast for the ancient Israelites at the creation of the Israelite nation, Jesus instituted the Lord's Supper at the inception of a new community that centred around his teachings and visions for a new humanity.

Stanley K. Stowers, in Kinds of Myth, Meals, And Power, argues that although the account of the abuses in the Lord's Supper contains an element of etiological myth, the account is best viewed as "the specification of a genre of eating." 635 Paul is attempting to offer general specifications about ritualised eating practices in relation to group social formation and the identity of the participants. ${ }^{636}$ For the Greeks, the truth about the identity of one's flesh and blood is revealed during the skilful cooking, sharing, and eating of meat in honour of the

${ }^{635}$ Stowers, "Kinds of Myth, Meals, And Powers," 136.

${ }^{636}$ Ibid., 137. 
gods. ${ }^{637}$ Against this backdrop, Paul works around the disjunction between the true self and the body by introducing the Lord's Supper, in which eating bread "is a symbol of an absent body that points both to the significance of giving up that body and to the loyalty of the social body toward the symbol." $" 638$

The differences in the conclusions drawn by Stowers and demonstrated in this study about the Lord's Supper result from the methods employed. From the outset, Stowers defines eating a meal as a practice "in which agents produce discourses." ${ }^{639} \mathrm{He}$ further explains, "in taking this perspective on a culture, it becomes clear that the wills of individuals do not control practices, nor are the supposed instruments of minds such as symbols, beliefs, intentions, texts, myths, and theories the meaning or basis of practice. ${ }^{640}$ This is an illustration of practice theory associated with the thought of Pierre Bourdieu, who invokes the concept of practice as a mediating concept to bridge a binary opposition between social structure and the agency of individuals. ${ }^{641}$ Crucial to the concept of practice is the principle of habitus, a "strategygenerating principle enabling agents to cope with unforeseen and ever-changing situations. ${ }^{, 642}$ This study, on the other hand, approaches the Lord's Supper and baptism from a performance tradition that analyses the socially disruptive and transformative potentials of ritual. Both approaches are valid. The former views ritual as part of a web of cultural systems and social dynamics in which the individual negotiates various power relations. ${ }^{643}$ The latter sees ritual in terms of drama, focusing on the experiential character of ritual performance for the participants. Moreover, the reason Stowers treats the Lord's Supper account in 1 Corinthians as part of a wider cultural practice instead of an etiological myth is his criticism of the concept of myth used in religious studies as timeless or background knowledge. Instead, he argues that myth should be treated as a product of contextualised discourse, meeting the needs of a specific setting. ${ }^{644}$ Although myths have been used in a variety of settings, whether in relating folklore or ritual performance, there are certain universal structure or elements encoded in myths that make them a myth. ${ }^{645}$ For instance, in the case of the Christ myth, there are certain elements

${ }^{637}$ Ibid., 137.

${ }^{638}$ Ibid., 137

${ }^{639}$ Ibid., 127.

${ }^{640}$ Ibid., 127.

${ }^{641}$ Pierre Bourdieu, Outline of a Theory of Practice, trans. Richard Nice (Cambridge: Cambridge University Press, 1977).

642 Bourdieu, Outline, 72.

${ }^{643}$ See Bell, Ritual Theory.

${ }^{644}$ Stowers, "Kinds of Myth, Meals, And Powers," 136n80. 2008).

${ }^{645}$ See Joseph Campbell, The Hero with a Thousand Faces, 3d ed (Novato, CA: New World Library, 
that underline it regardless of the interpretation or setting one wishes to deploy. These elements are Christ's death and resurrection, which are present whether they are interpreted in terms of a martyr's death, ${ }^{646}$ the Abrahamic lineage ${ }^{647}$ or the etiological myth of the Christ cult. Thus, one can view the Christ myth in the Lord's Supper as a discourse for testing the truth regarding one's own identity and group formation from a practice perspective and as a foundational myth to the origins of the Christ religion from the performance tradition point of view.

The second element of ritual entailment in baptism and the Lord's Supper is the sacred discourse, the sanctified expressions embedded in the ritual that oblige the participant to observe. In the baptism ritual, the sanctified expressions are the three-fold pronouncement of

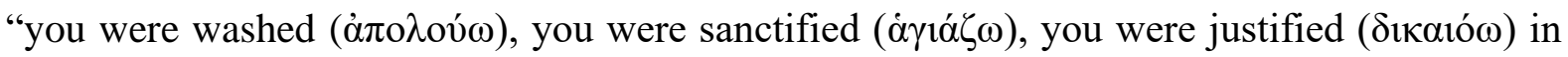
the name of the Lord Jesus Christ and in the Spirit of our God" (1 Cor 6:11). The term $\alpha$ to $\lambda$ ov́ $\omega$ denotes the negative aspect of purity in both physical and moral senses. The term $\dot{\alpha} \gamma i \alpha \dot{\zeta} \omega$ signifies that God is the source of holiness whose quality is imitated by his people when participating in the eschatological judgement. Finally, the term $\delta$ iкaı́ $\omega$ refers to God as the initiator of the judgement whose effect is the transformation of the person into a new creation. In the Lord's Supper ritual, there are terms and conventions to which the participants need to conform. According to those terms, the Corinthians needs to purify its community of people of immorality who have breached their obligations since, just as the celebration of the Passover meal requires unleavened bread, the Lord's Supper ritual stipulates that "the unleavened bread of sincerity and truth." Another term of the stipulation that the Corinthians have violated is participation in the pagan sacrifice, which is a liturgical taboo. Lastly, the conventional order of the Lord's Supper establishes a morality of unity within Christ's body, as shown in the act of sharing bread and wine.

3. Transformation: We now reach the crucial moment of ritual performance, namely, the transformation process of the participants, or the liminal state in which the participants undergo an existential transformation outside the structure of society into a new reality of existence. Emerging from the liminal state, the participants present themselves as a new creation, whose effects constitute a movement of ritual efficacy into the human world. We start with the discussion of the interior transformation of the participants in the liminal state.

${ }^{646}$ See Burton L. Mack, "Rereading the Christ Myth: Paul's Gospel and the Christ Cult Question," in Redescribing Paul and the Corinthians, ed. Ron Cameron and Merill P. Miller, ECIL 5 (Atlanta: SBL, 2011), $35-73$.

${ }^{647}$ See Johnson Hodge, If Sons, Then Heirs. 
a. Virtuality: The entry point into the virtual space afforded by the baptism ritual

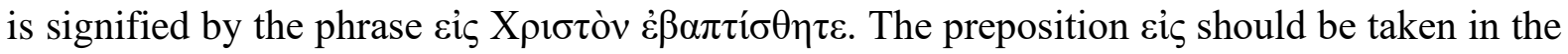
local sense, as a movement into Christ's sphere from outside it. In baptism, the participants are translated from the terrestrial sphere into the celestial sphere where they will reign with Christ. Once the participants have descended into the Christ space, they begin to engage in their existential formation by identifying with the Christ event, as illustrated by the series of $\sigma v v$

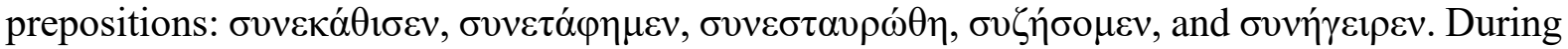
the process of re-orientation and re-configuration in the virtual space created by the baptism ritual, the participants engage in a program of engineering a new humanity that transcends ethnic, social, and sexual distinctions into which peoples are categorised. The entry point into

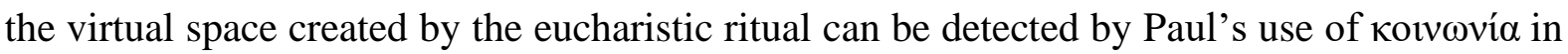
connection with the Lord's Supper: "The cup of blessing that we bless, is it not a sharing

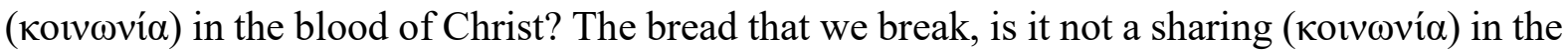

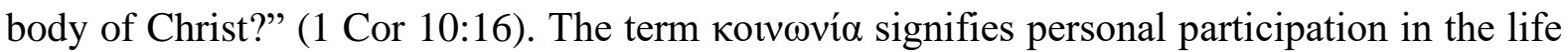
of Christ, since bread and wine symbolise the Christ as a victim, crucified in the sacrificial meal. The virtual space afforded by the meal ritual is a place in which fragmentation is healed, and people are made whole. This healing is made possible by the supernatural food provided at the meal ritual that sustains the life of the Corinthian community.

b. Historical emergence: What emerges from the ritual performance is the efficacy of the ritual. There are three issues accompanying the ritual emergence: the ritual authority, the historical and social circumstances surrounding the ritual performance, and the ritual impact on the wider society. We discuss them in turn. Regarding the ritual authority, in chapter two we discussed how the ritual controversy in the Galatians community revolves around the assertion of apostolic authority over the community, which has ramifications for the efficacy of the Gospel. For Paul, his gospel and mission to the Gentiles have a divine endorsement that is not contingent on human approval. If the Galatians accept the proposal made by the agitators to undergo circumcision, that would imply that Paul's gospel is incomplete and that the baptism ritual, which is the performance of that gospel, has failed to bring about the eschatological emergence promised in the gospel: a new creation. Against this position, Paul argues that baptism has achieved the agenda of the gospel, for Christ is the promised seed of Abraham, through whom the Law has been fulfilled (Gal 3:16; 4:4; Rom 8:3$4)$.

The discussion of the ritual context comes into the picture in connection with the historical and social circumstances accompanying ritual performance. We have analysed the 
social and cultural context in which baptism and the Lord's Supper are performed. Socially, Paul's use of baptismal language is concerned with kerygma and its implication for one's living in accordance therewith, while Paul's discussion of the Lord's Supper deals with the clash of different sacrificial rites within the wider ritual systems in the ancient Mediterranean world. Culturally, the baptism ritual, which is situated within the wider ritual practice of ablution, takes up the motifs of transformation, religious perfection, eschatology, and purification, and the Lord's Supper, against the backdrop of meal culture, shares the same motif of fellowship with gods in meals. These motifs, appropriated into the rituals of the nascent Christ religion, become ritual symbols or schemes that are enacted in the ritual performance.

Lastly, both baptism and the Lord's Supper have significant ramifications for the wider society in which the Christ followers lived. In the former, three implications can be delineated. Cosmologically, the program envisioned in the baptism constitutes a direct challenge to imperial Roman rule, that Christ is their king and has brought about a new creation with living water flowing from him (John 4:14; 7:37-39). Anthropologically, the communitas that emerged at baptism revolutionises the social stratification of the time, because all are now one in Christ. Eschatologically, a new creation has dawned, inaugurated by the Christ event. In the latter, the meal ritual provides Christ followers with the imaginative power to renegotiate the current social order in relation to imperial domination; they receive a new cosmic vision in which Christ is the ruler over creation.

4. Relationality: The final stage of the ritual transformation process is the reconfiguration of relationships amongst the participants and between the divine and human. On the human side, both baptism and the Lord's Supper serve to alleviate the conflicts amongst the Christ followers arising from their different social backgrounds by incorporating them into the new society of the body of Christ. On the divine side, the relation between God and the human participants is expressed through nuptial imagery and ratified at the meal ritual.

\subsection{Questions Answered}

Having laid out the argument, we can answer the questions that were posed at the beginning of our study.

1. Do baptism and the Lord's Supper play a role in the process of uniting with Christ?

Yes, baptism and the Lord's Supper do play a role in the process of uniting with

Christ. As an entry rite, baptism initiates the participants into the Christ mysteries by transferring the baptizands from the profane world into Christ's sphere. As a 
communion rite, the Lord's Supper unites the participants with Christ through the acts of the fellowship of bread and wine that signify the sharing of Christ's very life.

2. What is the relation between these two rituals and Paul's participatory language?

Based on the syntactical analysis of passages that contain both ritual references and "in Christ" language, we establish that the rituals correspond to the dual aspects of union with Christ: baptism to the dynamic aspect and the Lord's Supper to the static aspect.

3. What is the relation between pistis and ritual?

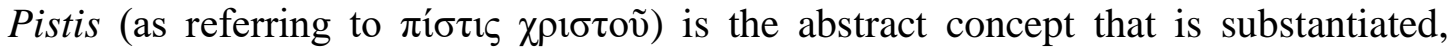
embodied, and created by the physical and material forms of ritual. Baptism incarnates the revelation of pistis, ritually resolves the disunities amongst Christ's body to enable realising of the gift of pistis therein, ratifies the new covenant in the form of pistis, and

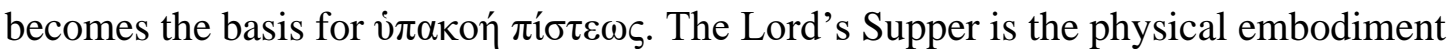
of pistis that is worked through love.

\subsection{Significance and Further Study}

Given the natural affinity between the notion of participation in Paul and the ritual model of transformation, this study has investigated the ritual aspect of participation in Christ, an area that has seldom been studied. Given the longstanding polemics in scholarly debates about baptism and the Lord's Supper in relation to union with Christ, this study choses ritual theories that could illuminate the question of how baptism and the Lord's Supper facilitate the union with Christ. Treating those rites in ritual instead of theological terms (i.e., sacraments) has the advantage of bypassing the endless theological debates over how - or even whether - God infuses grace to humans through these sacraments, a subject that is beyond the inquiry of biblical studies. Rather, throughout this study we have focused on the ritual functions of these rites in relation to their social and cultural backgrounds and their social ramifications. Thus, this study has played a major part in filling a lacuna in the scholarship on the ritual aspect of union with Christ.

Furthermore, this study is part of a growing trend in the scholarship to renew studies of early Christian rituals. The earlier scholarship is marked by word-centred and faith-focused approach, along with a strong anti-ritual bias. In reaction, Catholic scholarship projected its 
own ritual practices and forms onto the early rites and ceremonies of the Christ religion. ${ }^{648} \mathrm{~A}$ more balanced approach would find the middle ground between these two extremes, and this is where ritual studies come to the forefront by offering rigorous theoretical frameworks that can be deployed in historical and social investigations of the ritual life of the nascent Christ religion. After all, the Christ movement originated from the lived experience of encounters with the risen messiah. To understand how the collective religious experience of early Christ followers has been transformed into a movement that has now global influence on the social, political, and religious landscape, one must not neglect the practices of the early Christ movement, in addition to studying their religious texts. In fact, these texts bear testimony to the living encounter with the divine to which the texts point (1 John 1:1-3).

This study has selected a wide array of ritual theories and amended some to produce a new theoretical framework of a ritual transformation model to study two cardinal rituals in the early Christ movement: baptism and the Lord's Supper. This model has worked well in elucidating the ritual process of transformation afforded by these two rituals. Moreover, this study is a response to the call for a new direction in the study of early Christian rituals in the recent volume Early Christian Ritual Life. A new line of inquiry opened by this study would involve include other Christ groups' ritual practices, such as Johannine communities, in relation to the notions of transformation and participation in Christ.

\subsection{Final Thought}

This study has demonstrated the significance of ritual in the religious experience of the early Christ movement. This new movement emerged from a collective experience of encountering a risen messiah. To experience this divine encounter, the ritual performance provided a space in which the participants could encounter the transformative power of the risen messiah. Ritual activities provide more than a mere transmission of sacred doctrines; rather, they create a metaphysical world of imagination in a mundane world to transform the existential predicament facing the participants into a portal of change, of a new creation, and of new hope, insofar as the ritual performance is successful.

${ }^{648}$ Hal Taussig, "Steps Forward in the Study of Early Christian Ritual Life," in Early Christian Ritual Life, ed. Richard E. DeMaris et al. (London: Routledge, 2017), 183-84. 


\section{Bibliography}

\section{Primary sources}

Ancient Christian Writers series. 1946-. Mahwah, NJ: Paulist Press.

Apuleius Of Madauros. The Isis-Book (Metamorphoses, Book XI). Edited by J. Gwyn Griffiths. Leiden: Brill, 1975.

The Apostolic Fathers: Greek Texts and English Translations. Translated by M. W. Holmes. 3d ed. Grand Rapids: Baker Academic, 2007.

Aristotle. The Complete Works of Aristotle: The Revised Oxford Translation. Translated by Jonathan Barnes. Princeton University Press, 2014.

Cato, Varro. Cato on Farming : De Agricultura: a Modern Translation with Commentary by Andrew Dalby. Blackawton: Prospect Books, 1998.

Charlesworth, James Hamilton, ed. The Old Testament Pseudepigrapha. 2 vols. London: Darton, Longman and Todd, 1983-1985.

Cicero, Marcus Tullius. Cicero: On the nature of the gods. Translated by Patrick Gerard Walsh. Oxford: Oxford Univ. Press. 1997.

Diodorus Siculus. The antiquities of Egypt. A translation with notes of Book I of the library of history. 2d ed. Edited by Edwin Murphy. New Brunswick, NJ: Transaction, 1990.

Diodorus Siculus. The antiquities of Asia. A translation with notes of Book II of the library of history. Edited by Edwin Murphy. New Brunswick, NJ: Transaction, 1989.

Dionysius of Halicarnassus. Roman Antiquities, Volume II: Books 3-4. Translated by Earnest Cary. LCL 347. Cambridge: Harvard University Press, 1939.

Elliott, J.K. The Apocryphal New Testament: A Collection of Apocryphal Christian Literature in an English Translation based on M. R. James. Oxford: Clarendon Press, 1993.

Epictetus. Epictetus: Discourses, fragments, handbook. With an introduction and notes by Christopher Gill. Edited by Robin Hard. Oxford: Oxford Univ. Press, 2014.

Fathers of the Church. 1947-. Washington, DC: Catholic University of America Press.

Herodotus. The landmark Herodotus: The histories. Edited by Robert B. Strassler; translated by Andrea L. Purvis. New York: Pantheon, 2007.

Homeric Hymns. Homeric Apocrypha. Lives of Homer. Edited and translated by Martin L. West. LCL 496. Cambridge: Harvard University Press, 2003.

Josephus. Translated by H. Thackeray et al. 13 vols. LCL. London: Heinemann, 1926-1965.

Justin. The First and Second Apologies / St. Justin Martyr ; Translated with Introduction and Notes by Leslie William Barnard. New York: Paulist Press, 1997.

Justin. Dialogue avec Tryphon. Texte grec, traduction française, introduction, notes et index. Translated by G. Archamault. Textes et documents pour l'étude historique du christianisme. 2 vols. Paris: Librairie Alphonse Picard et Eils, 1909.

Juvenal, Persius. Juvenal and Persius. Edited and translated by Susanna Morton Braund. LCL 91. Cambridge: Harvard University Press, 2004. 
Livy. Livy: Rome and Italy. Translated by Betty Radice. London: Penguin, 1982.

Marcus Aurelius. Marcus Aurelius: Meditations: Books 1-6. Introduction and commentary by Christopher Gill. Translated by Christopher Gill. Oxford: Oxford Univ. Press, 2013.

Martial, Marcus Valerius. Epigrams. Translated by James Michie. New York: Modern Library, 2002.

New Revised Standard Version Bible. Oxford: Oxford University Press, 1989.

Novum Testamentum Graece. Edited by B. Aland et al. 28th ed. Stuttgart: Deutsche Bibelgesellschaft, 2012.

The Old Testament Pseudepigrapha. Edited by J. H. Charlesworth. 2 vols. New York: Doubleday, 1983-1985.

Philo. Every Good Man is Free. On the Contemplative Life. On the Eternity of the World. Against Flaccus. Apology for the Jews. On Providence. Translated by F. H. Colson. Loeb Classical Library 363. Cambridge, MA: Harvard University Press, 1941.

Philo. On Abraham. On Joseph. On Moses. Translated by F. H. Colson. Loeb Classical Library 289. Cambridge, MA: Harvard University Press, 1935.

Philo. On Flight and Finding. On the Change of Names. On Dreams. Translated by F. H. Colson, G. H. Whitaker. Loeb Classical Library 275. Cambridge, MA: Harvard University Press, 1934.

Philo. On the Creation. Allegorical Interpretation of Genesis 2 and 3. Translated by F. H. Colson, G. H. Whitaker. Loeb Classical Library 226. Cambridge, MA: Harvard University Press, 1929.

Philo. On the Decalogue. On the Special Laws, Books 1-3. Translated by F. H. Colson. Loeb Classical Library 320. Cambridge, MA: Harvard University Press, 1937.

Pindar. Nemean Odes. Isthmian Odes. Fragments. Edited and translated by William H. Race. LCL 485. Cambridge: Harvard University Press, 1997.

Plato. The complete works. Edited by John M. Cooper and Douglas S. Hutchinson. Indianapolis, IN: Hackett, 1997.

Pliny the Younger. Letters, Volume I: Books 1-7. Translated by Betty Radice. LCL 55. Cambridge: Harvard University Press, 1969.

Plutarch. Plutarch Moralia: Index / Compiled by Edward N. O’Neil. Cambridge, Mass.: Harvard University Press, 2004.

Tertullian. Tertullian's Homily on Baptism. Translated and edited by Ernest Evans. London: SPCK, 1964.

Vermès, Géza, ed. and trans. The Complete Dead Sea Scrolls in English. Rev. ed. London: Penguin, 2004.

Virgil. The Eclogues. Edited and translated by Guy Lee. Penguin Classics. Harmondsworth, UK: Penguin, 1984.

Xenophon.The landmark Xenophon's Hellenika: A new translation. Edited by Strassler R. New York: Pantheon, 2009. 


\section{Secondary sources}

Achtemeier, Paul J. "Apropos the Faith of/in Christ: A Response to Hays and Dunn." Pages 82-92 in Pauline Theology, Volume IV: Looking Back, Pressing On. Edited by Elizabeth Johnson and David M. Hay. Atlanta: Scholars Press, 1997.

Adams, Edward. The Earliest Christian Meeting Places: Almost Exclusively Houses? London: Bloomsbury, 2013.

Agersnap, Søren. Baptism and the New Life: A Study of Romans 6.1-14. Aarhus: Aarhus: University Press, 1999.

Aletti, Jean-Noel. Justification by Faith in the Letters of Saint Paul Keys to Interpretation. Translated by Peggy Manning Meyer. Rome: Gregorian \& Biblical Press, 2015.

Alikin, Valeriy A. The Earliest History of the Christian Gathering: Origin, Development and Content of the Christian Gathering in the First to Third Centuries. SVC 102. Leiden: Brill, 2010.

Arndt, William, Frederick W. Danker, and Walter Bauer. A Greek-English Lexicon of the New Testament and Other Early Christian Literature. 3d ed. Chicago: University of Chicago Press, 2000.

Asano, Atsuhiro. Community-Identity Construction in Galatians: Exegetical, SocialAnthropological and Socio-Historical Studies. JSNTSup 285. London: T\&T Clark, 2005.

Ascough, R. S. "The Completion of a Religious Duty: The Background of 2 Cor 8:1-15." NTS 42 (1996): 584-99.

Austin, J. L. How to Do Things with Words. Oxford: Oxford University Press, 1962.

Bacchiocchi, Samuele. Wine in the Bible: A Biblical Study on the Use of Alcoholic Beverages. Berrien Springs, MI: Biblical Perspectives, 1989.

Baer, Heinrich von. Der Heilige Geist in Den Lukasschriften. Stuttgart: W. Kohlhammer, 1926.

Baker, Mary Patton. "Participating in the Body and Blood of Christ: Christian kovvovía and the Lord's Supper." Pages 503-28 in "In Christ" in Paul. Edited by Michael J. Thate et al. WUNT 384. Tübingen: Mohr Siebeck, 2014.

Baldry, H. C. The Unity of Mankind in Greek Thought. Cambridge: Cambridge University Press, 1965.

Barclay, John M. G. "Stoic Physics and the Christ-event: A Review of Troels EngbergPedersen, Cosmology and Self in the Apostle Paul: The Material Spirit (Oxford: Oxford University Press, 2010).” JSNT 33 (2011): 406-14.

Barrett, Charles Kingsley. A Commentary on the Epistle to the Romans. 2d ed. BNTC; HNTC. London: Black; New York: Harper, 1991.

Barth, Gerhard. Die Taufe in frühchristlicher Zeit. Neukirchen-Vluyn: Neukirchener, 1981.

Beasley-Murray, G. R. Baptism in the New Testament. London: Macmillan, 1962. 
Becker, Jürgen. Der Brief an die Galater. NTD 8/1. Göttingen: Vandenhoeck \& Ruprecht, 1998.

Bell, Catherine. Ritual Perspectives and Dimensions. Oxford: Oxford University Press, 1997.

Bell, Catherine. "Ritual Reification." Pages 265-83 in Ritual and Religious Belief: A Reader. Edited by Graham Harvey. London: Equinox, 2005.

Bell, Catherine. Ritual Theory, Ritual Practice. Oxford: Oxford University Press, 1992.

Bell, Richard H. "Faith in Christ: Some Exegetical and Theological Reflections on Philippians 3:9 and Ephesians 3:12." Pages 111-25 in The Faith of Jesus Christ: Exegetical, Biblical, and Theological Studies. Edited by Michael F. Bird and Preston M. Sprinkle. Peabody, MA: Hendrickson, 2009.

Best, Thomas F. "The Sociological Study of the New Testament: Promise and Peril of a New Discipline." SJT 36, no. 2 (1983): 181-94.

Betz, Hans Dieter. Galatians A Commentary on Paul's Letter to the Churches In Galatia. Hermeneia; Philadelphia: Fortress Press, 1979.

Betz, Hans Dieter. "Jesus' Baptism and the Origins of the Christian Ritual." Pages 377-93 in Ablution, Initiation, and Baptism: Late Antiquity, Early Judaism, and Early Christianity. Edited by David Hellholm et al. Berlin: De Gruyter, 2011.

Betz, Hans Dieter. "Transferring a Ritual: Paul's Interpretation of Baptism in Romans 6." Pages 84-118 in Paul in His Hellenistic Context. Edited by Troels Engberg-Pedersen. Edinburgh: T\&T Clark, 1994.

Black, Matthew. Romans. NCBC. Grand Rapids: Eerdmans, 1973.

Blidstein, Moshe. "Baptism as Purification in Early Christian Texts." Pages 107-34 in Purity, Community, and Ritual in Early Christian Literature. Oxford: Oxford University Press, 2017.

Bligh, John. Galatians: A Discussion of St. Paul's Epistle. London: St. Paul Publications, 1969.

Blomqvist, Jerker, and Karin Blomqvist. "Eucharist Terminology in Early Christian Literature: Philological and Semantic Aspects." Pages 389-421 in The Eucharist-Its Origins and Contexts: Sacred Meal, Communal Meal, Table Fellowship in Late Antiquity, Early Judaism and Early Christianity, Volume III. Edited by David Hellholm and Dieter Sanger. Tübingen: Mohr Siebeck, 2017.

Bockmuehl, Markus. Seeing the Word. Grand Rapids: Baker Academic, 2006.

Bornkamm, Günther. Das Ende des Gesetzes: Paulusstudien. BEvT 16. Munich: Christian Kaiser, 1952.

Bourdieu, Pierre. The Logic of Practice. Translated by Richard Nice. Stanford: Stanford University Press, 1990.

Bourdieu, Pierre. Outline of a Theory of Practice. Translated by Richard Nice. Cambridge: Cambridge University Press, 1977.

Bousset, Wilhelm, Kyrios Christos: A History of the Belief in Christ from the Beginnings of Christianity to Irenaeus. Translated by John E. Steely. Nashville: Abingdon, 1970. 
Bouttier, Michel. En Christ: étude d'exégèse et de théologie pauliniennes. Paris: Presses universitaires de France, 1962.

Bouyer, Louis. Eucharist: Theology and Spirituality of the Eucharistic Prayer. Translated by C. U. Quinn. Notre Dame: University of Notre Dame Press, 1968.

Bowden, Hugh. Mystery Cults in the Ancient World. London: Thames \& Hudson, 2010.

Bradshaw, Paul F. Eucharistic Origins. ACC 80. London: SPCK, 2004.

Brandenburger, Egon. Adam und Christus: Exegetisch-Religionsgeschichtliche Untersuchung zu Röm. 5:12-21 (1. Kor. 15). WMANT 7. Neukirchen: Neukirchener Verlag, 1962.

Bremmer, Jan N. Initiation into the Mysteries of Ancient World. Berlin: De Gruyter, 2014.

Brent, Allen. Ignatius of Antioch: A Martyr Bishop and the Origin of Episcopacy. London: T\&T Clark, 2007.

Bring, Ragnar. Commentary on Galatians. Translated by Eric Wahlstrom. Philadelphia: Muhlenberg, 1961.

Brown, Raymond E., Joseph A. Fitzmeyer, and Roland E. Murphy, eds. The New Jerome Biblical Commentary. Englewood Cliffs, NJ: Prentice Hall, 1990.

Bruce, F. F. 1 and 2 Corinthians. NCBC. Grand Rapids: Eerdmans, 1971.

Bruce, F. F. The Epistle to the Romans. London: Tyndale Press, 1963.

Brueggemann, Walter. Texts Under Negotiation: The Bible and Postmodern Imagination. Minneapolis: Fortress, 1993.

Bubbers, Susan I. A Scriptural Theology of Eucharistic Blessings. London: T\&T Clark, 2013.

Buc, Philippe. The Dangers of Ritual: Between Early Medieval Texts and Social Scientific Theory. Princeton: Princeton University Press, 2001.

Büchsel, Friedrich. “"In Christu’ bei Paulus.” ZNW 42 (1949): 141-58.

Bultmann, Rudolf. "Adam and Christ According to Romans 5." Pages 143-65 in Current Issues in New Testament Interpretation: Essays in Honor of Otto A. Piper. Edited by W. Klassen and G. F. Snyder. New York: Harper, 1962.

Burchard, Christoph. "The Importance of Joseph and Aseneth for the Study of the New Testament: A General Survey and a Fresh Look at the Lord's Supper.” NTS 33, no. 1 (1987): 102-34.

Burkert, Walter. Ancient Mystery Cult. Cambridge: Harvard University Press, 1987.

Burkert, Walter, René Girard, and Jonathan Z. Smith. Violent Origins. Edited by Robert G. Hamerton-Kelly. Stanford: Stanford University Press, 1987.

Burkes, Kenneth. Dramatism and Development. Barre, MA: Clark University Press, 1972.

Bynum, C. W. The Resurrection of the Body in Western Christianity, 200-1336. New York: Columbia University Press, 1995.

Byrne, Brendan. “"The Type of the One to Come' (Rom 5:14): Fate and Responsibility in Romans 5:12-21." ABR 36 (1988): 19-30. 
Campbell, Constantine R. Paul and Union with Christ: An Exegetical and Theological Study with Christ. Grand Rapids: Zondervan, 2012.

Campbell, Douglas A. "The Faithfulness of Jesus Christ in Romans 3:22." Pages 57-71 in The Faith of Jesus Christ: Exegetical, Biblical, and Theological Studies. Edited by Michael F. Bird and Preston M. Sprinkle. Peabody, MA: Hendrickson, 2009.

Campbell, Douglas A. "The Meaning of Pistis and Nomos in Paul: A Linguistic and Structural Perspective." JBL 111, no. 1 (1992): 91-103.

Campbell, Joseph. The Hero with a Thousand Faces. 3d ed. Novato, CA: New World Library, 2008.

Campbell, R. Alastair. NovT 33, no. 1 (1991): 61-70.

Capes, David B. Old Testament Yahweh Texts in Paul's Christology. Wissenschaftliche Untersuchungen zum Neuen Testament 2. Tübingen, Germany: J. C. B. Mohr, 1992.

Carney, T. F. The Shape of the Past: Models and Antiquity. Lawrence, KS: Coronado Press, 1975.

Carter, Jeffrey, ed. Understanding Religious Sacrifice: A Reader. London: Continuum, 2003.

Casel, Odo. The Mystery of Christian Worship: and Other Writings. Westminster, MD: Newman Press, 1962.

Chauvet, L. M. Symbol and Sacrament: A Sacramental Reinterpretation of Christian Existence. Translated by P. Madigan and M. Beaument. Collegeville, MN: The Liturgical Press, 1995.

Chester, Stephen J. Conversion at Corinth: Perspectives on Conversion in Paul's Theology and the Corinthian Church. London: T\&T Clark, 2003.

Childs, B. S. Memory and Tradition in Israel. Naperville, IL: Alec R. Allenson, 1961.

Chilton, Bruce. A Feast of Meanings: Eucharistic Theologies from Jesus through Johannine Circles. Leiden: Brill, 1994.

Choi, Agnes. "Boundary-Crossing in Christian Baptism." Pages 75-91 in Early Christian Ritual Life. Edited by Richard E. DeMaris et al. London: Routledge, 2017.

Clancy, Robert A. D. "The Old Testament Roots of Remembrance in the Lord's Supper." Concordia Journal 19, no. 1 (1993): 35-50.

Clark, Neville, "Initiation and Eschatology." Pages 337-49 in Baptism, the New Testament and the Church: Historical and Contemporary Studies in Honour of R. E. O. White. Edited by Stanley E. Porter and Anthony R. Cross. JSNTSup 171. Sheffield: Sheffield Academic Press, 1999.

Cohen, Ted. "Metaphor and the Cultivation of Intimacy." Critical Inquiry 5, no. 1 (1978): 312.

Cohn, Haim H. "Slavery." Pages 1655-60 in EncJud 14. Edited by Cecil Roth and Geoffrey Wigoder. 16 vols. London: Macmillan, 1971.

Cole, R. L. Love-Feasts: A History of the Christian Agape. London: Charles H. Kelly, 1916. 
Collins, Raymond F. First Corinthians. Edited by Daniel J. Harrington. SP 7. Collegeville, MN: The Liturgical Press, 1999.

Compton, R. Bruce. "The 'Ordo Salutis' and Monergism: The Case for Faith Preceding Regeneration, Part 3.” BSac 175, no. 699 (2018): 284-303.

Conzelmann, Hans. 1 Corinthians: A Commentary on the First Epistle to the Corinthians. Edited by George W. MacRae. Translated by James W. Leitch. Philadelphia: Fortress Press, 1975.

Cranfield, C. E. B. A Critical and Exegetical Commentary on the Epistle to the Romans, Volume 1. ICC. Edinburgh: T\&T Clark, 1975.

Crehan, Joseph. Early Christian Baptism and the Creed: A Study in Ante-Nicene Theology. The Bellarmine Series 13. London: Burns, Oates \& Washbourne, 1950.

Crockett, W. R. Eucharist: Symbol of Transformation. New York: Pueblo Publishing Co., 1989.

Cross, Anthony R. "Spirit- And Water-Baptism in 1 Corinthians 12.13." Pages 120-48 in Dimensions of Baptism: Biblical and Theological Studies. Edited by Stanley E. Porter and Anthony R. Cross, JSNTSup 234. Sheffield: Sheffield Academic Press, 2002.

Cullmann, Oscar. Baptism in the New Testament. SBT 1. London: SCM Press, 1950.

Dahl, Nils Alstrup. Studies in Ephesians: Introduction Questions, Text- and Edition-Critical Issues, Interpretation of Texts and Themes. WUNT 131. Tübingen: Mohr Siebeck, 2000.

Daly, Robert J. The Origins of the Christian Doctrine of Sacrifice. London: Darton, Longman and Todd, 1978.

Das, A. Andrew. "1 Corinthians 11:17-34 Revisited.” CTQ 62, no. 3 (1998): 193-97.

Das, A. Andrew. Galatians: Concordia Commentary. Saint Louis: Concordia Publishing House, 2014.

Davies, W. D. Paul and Rabbinic Judaism: Some Rabbinic Elements in Pauline Theology. 3d ed. London: SPCK, 1970.

Davila, James R. Liturgical Works: Eerdmans Commentaries on the Dead Sea Scrolls. Edited by Martin G. Abegg, Jr. and Peter W. Flint. Grand Rapids: Eerdmans, 2000.

De Boer, Martinus C. Galatians: A Commentary. NTL. Louisville: Westminster John Knox Press, 2011.

De Boer, P. A. H. Gedenken und Gedächtnis in der Welt des Alten Testaments. Stuttgart: W. Kohlhammer Verlag, 1962.

Deissmann, Adolf. Light from the Ancient East: The New Testament Illustrated by Recently Discovered Texts of the Graeco-Roman World. London: Hodder \& Stoughton, 1927.

Deissmann, Adolf. Paul: A Study in Social and Religious History. 2d ed. Translated by Lionel R. M. Strachan. London: Hodder \& Stoughton, 1926.

DeMaris, Richard E. The New Testament in its Ritual World. London: Routledge, 2008.

DeMaris, Richard E. "Water Ritual." Pages 391-408 in The Oxford Handbook of Early Christian Ritual. Edited by Risto Uro et al. Oxford: Oxford University Press, 2019. 
Despotis, Athanasios "O Г⿳亠े $\rho$ A A Conversion from the Perspective of Rom 6:7." Pages 29-58 in Participation, Justification, and Conversion: Eastern Orthodox Interpretation of Paul and the Debate Between "Old and New Perspectives on Paul." Edited by Athanasios Despotis. WUNT II 442. Tübingen: Mohr Siebeck, 2017.

Despotis, Athanasios. "Reconsidering the Pauline Conception of Time." JSPL 8 (2018): 20-42

Despotis, Athanasios. 'From Conversion in Paul and 'John' to Theosis in Their Patristic Reception." HBT 38 (2016) 88-109.

Despotis, Athanasios. "Beyond Theological Argument: The Ethics of Love and Coming to Faith in Paul." Pages 349-69 in Participation, Justification, and Conversion: Eastern Orthodox Interpretation of Paul and the Debate Between "Old and New Perspectives on Paul." Edited by Athanasios Despotis. WUNT II 442. Tübingen: Mohr Siebeck. 2017.

Dijkhuizen, Petra. "The Lord's Supper and Ritual Theory: Interpreting 1 Corinthians 11:30 in Terms of Risk, Failure, and Efficacy." Neotestamentica 50, no. 2 (2016): 441-76.

Douglas, Mary. “Atonement in Leviticus.” JSQ 1, no. 2 (1993-1994): 109-30.

Douglas, Mary. "The Eucharist: Its Continuity with the Bread Sacrifice of Leviticus." Modern Theology 15, no. 2 (1999): 209-24.

Douglas, Mary. Purity and Danger: An Analysis of Concept of Pollution and Taboo. London: Routledge, 2008.

Douglas, W. W. "The Meanings of 'Myth' in Modern Criticism.” Modern Philology 50 (1953): $232-42$.

Dudley, Guilford III. Religion on Trial: Mircea Eliade and His Critics. Philadelphia: Temple University Press, 1977.

Dunn, James D. G. Baptism in the Holy Spirit: A Re-Examination of the New Testament Teaching on the Gift of the Spirit in Relation to Pentecostalism Today. London: SCM Press, 1970.

Dunn, James D. G. “"Baptized' as Metaphor." Pages 294-310 in Baptism, the New Testament and the Church: Historical and Contemporary Studies in Honour of R. E. O. White. Edited by Stanley E. Porter and Anthony R. Cross. Sheffield: Sheffield Academic Press, 1999.

Dunn, James D. G. “Once More, ' $\pi \iota \tau 1 \varepsilon \chi \rho ı \tau \tau o \tilde{.} . "$ Pages 61-81 in Pauline Theology, Volume IV: Looking Back, Pressing On. Edited by Elizabeth Johnson and David M. Hay. Atlanta: Scholars Press, 1997.

Dunn, James D. G. The Theology of Paul the Apostle. Grand Rapids: Eerdmans, 1998.

Dunn, James D. G. Word Biblical Commentary: Volume 38A, Romans 1-8. Waco, TX: Word Books, 1988.

Eckey, Wilfried. Der Galaterbrief: Ein Kommentar. Neukirchen-Vluyn: Neukirchener, 2010. 
Eilberg-Schwartz, Howard. The Savage in Judaism: Anthropology of Israelite Religion and Ancient Judaism. Bloomington: Indiana University Press, 1990.

Ekroth, Gunnel. "Sacred Meals in Ancient Greece? Dining in Domestic Settings as Compared to Sanctuaries." Pages 1389-1406 in The Eucharist-Its Origins and Contexts: Sacred Meal, Communal Meal, Table Fellowship in Late Antiquity, Early Judaism and Early Christianity, Volume III. Edited by David Hellholm and Dieter Sanger. Tübingen: Mohr Siebeck, 2017.

Eliade, Mircea. Rites and Symbols of Initiations: The Mysteries of Birth and Rebirth. New York: Putnam, 1958.

Elliott, John H. What Is Social-Scientific Criticism? Minneapolis: Fortress Press, 1993.

Elliott, Mark W. " $\pi i ́ \sigma \tau \iota \varsigma ~ \chi \rho ı \sigma \tau o \tilde{~ i n ~ t h e ~ C h u r c h ~ F a t h e r s ~ a n d ~ B e y o n d . " ~ P a g e s ~ 277-89 ~ i n ~ T h e ~}$ Faith of Jesus Christ: Exegetical, Biblical, and Theological Studies. Edited by Michael F. Bird and Preston M. Sprinkle. Peabody, MA: Hendrickson, 2009.

Engberg-Pedersen, Troels. Cosmology and Self in the Apostle Paul: The Material Spirit. Oxford: Oxford University Press, 2010.

Eriksson, Anders. Traditions as Rhetorical Proof: Pauline Argumentation in 1 Corinthians. ConBNT 29. Stockholm: Almqvist \& Wiksell, 1998.

Ervin, Howard M. Conversion-Initiation and the Baptism in the Holy Spirit: A Critique of James D. G. Dunn, Baptism in the Holy Spirit. Peabody, MA: Hendrickson, 1970.

Eshel, E. "Apotropaic Prayers in the Second Temple Period." Pages 69-88 in Liturgical Perspectives: Prayer and Poetry in Light of the Dead Sea Scrolls. Edited by E. G. Chazon. Leiden: Brill, 2003.

Esler, Philip F. The First Christians in their Social World: Social-Scientific Approach to New Testament Interpretation. London: Routledge, 1994.

Esler, Philip F, ed. Modelling Early Christianity: Social-Scientific Studies of the New Testament in Its Context. London: Routledge, 1995.

Esler, Philip F. Review of The Social Ethos of the Corinthian Correspondence. Interests and Ideology from 1 Corinthians to 1 Clement." JTS 49, no. 1, 1998: 253-60.

Eurell, John-Christian. "Faith: An Activity of Christ or of the Believer? A Contribution to the

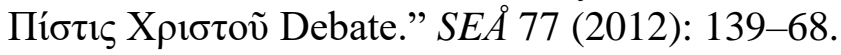

Fahim, Sherif A. "Obedience of Faith in Romans 1:5." Puritan Reformed Journal 9, no. 2, (2017): 53-77.

Fee, Gordon D. God's Empowering Presence: The Holy Spirit in the Letters of Paul. Peabody, MA: Hendrickson Publishers, 1994.

Fee, Gordon D. The First Epistle to the Corinthians. Grand Rapids: Eerdmans, 1987.

Ferguson, Everett. Baptism in the Early Church: History, Theology, and Liturgy in the First Five Centuries. Grand Rapids: Eerdmans, 2009.

Fernandez, James W. Persuasions and Performances: The Play of Tropes in Culture. Bloomington: Indiana University Press, 1986.

Finlan, Stephen. "Spiritualization of Sacrifice.” SEA 78 (2013): 57-86. 
Finlan, Stephen, and Vladimir Kharlamov, eds. Theosis: Deification in Christian Theology. James Clarke \& Co., 2012.

Fiorenza, Elisabeth Schüssler. In Memory of Her: A Feminist Theological Reconstruction of Christian Origins. London: SCM Press, 1983.

Fitzmyer, Joseph A. First Corinthians: A New Translation with Introduction and Commentary, AB 32. New Haven: Yale University Press, 2008.

Fitzmyer, Joseph A. Romans: A New Translation, with Introduction and Commentary. New York: Doubleday, 1993.

Fitzmyer, Joseph A. "The Semitic Background of the New Testament Kyrios-Title." Pages 115-142 in A Wandering Aramean: Collected Aramaic Essays. Edited by Joseph A. Fitzmyer. Society of Biblical Literature Monograph 25. Missoula, MT: Scholars Press, 1979.

Flusser, David. Judaism and the Origins of Christianity. Jerusalem: Magnes Press, 1988.

Fontenrose, Joseph. The Ritual Theory of Myth. Berkeley: University of California Press, 1966.

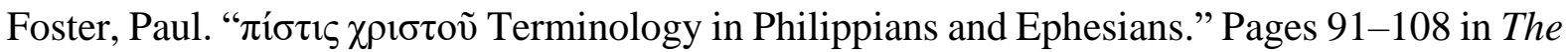
Faith of Jesus Christ: Exegetical, Biblical, and Theological Studies. Edited by Michael F. Bird and Preston M. Sprinkle. Peabody, MA. Hendrickson, 2009.

Fowl, Stephen E. Ephesians: A Commentary. Louisville: Westminster John Knox Press, 2012.

Freyne, Sean. "Jewish Immersion and Christian Baptism: Continuity on the Margins?" Pages 221-54 in Ablution, Initiation, and Baptism: Late Antiquity, Early Judaism, and Early Christianity. Edited by David Hellholm et al. Berlin: De Gruyter, 2011.

Fried, Martha, and Morton Fried, Transitions: Four Rituals in Eight Cultures. New York: W.W. Norton, 1980.

Fung, Ronald Y. K. The Epistle to the Galatians. Grand Rapids: Eerdmans, 1988.

Furnish, Victor Paul. "Belonging to Christ: A Paradigm for Ethics in First Corinthians." Interpretation 44, no. 2, (1990): 145-57.

Furstenberg, Yair. "Initiation and the Ritual Purification from Sin: Between Qumran and the Apostolic Tradition.” DSD 23, no. 3 (2016): 365-94.

Garland, David E. 1 Corinthians: Baker Exegetical Commentary on the New Testament. Edited by Robert W. Yarbrough and Robert H. Stein. Grand Rapids: Baker Academic, 2003.

Garlington, Don B. "Paul's 'Partisan Eк' and the Question of Justification in Galatians." JBL 127, no. 3 (2008): 567-89.

Gaventa, Beverly Roberts, “'You Proclaim the Lord's Death': 1 Corinthians 11:26 and Paul's Understanding of Worship." RevExp 80, no. 3 (1983): 377-87.

Geertz, Clifford. The Interpretation of Cultures: Selected Essays by Clifford Geertz. New York: Basic Books, 1973.

Delling, G. Die Zueignung des Heils in der Taufe. Berlin: Evangelische Verlagsanstalt, 1961. 
Gennep, Arnold van. The Rite of Passage. Translated by Monika B. Vizedom and Gabrielle L. Caffee. London: Routledge \& Kegan Paul, 1960.

Gilders, William K. "Jewish Sacrifice: Its Nature and Function (according to Philo)." Pages 95-109 in Ancient Mediterranean Sacrifice. Edited by Jennifer Wright Knust et al. Cary: Oxford University Press, 2011.

Girard, René. Violence and the Sacred. Translated by Patrick Gregory. London: Bloomsbury Academic, 2017.

Goppelt, Leonard. Theology of the New Testament 2: The Variety and Unity of the Apostolic Witness to Christ. Grand Rapids: Eerdmans, 1982.

Gorman, Frank H. The Ideology of Ritual: Space, Time and Status in the Priestly Theology. Sheffield: JSOT Press, 1990.

Gorman, Frank H. "Ritual Studies and Biblical Studies: Assessment of the Past, Prospects for the Future." Semeia 67 (1994): 13-36.

Gorman, Michael J. Inhabiting the Cruciform God. Grand Rapids: Eerdmans, 2009.

Graf, Fritz. "Baptism and Graeco-Roman Mystery Cults." Pages in 101-18 in Ablution, Initiation, and Baptism: Late Antiquity, Early Judaism, and Early Christianity. Edited by David Hellholm et al. Berlin: De Gruyter, 2011.

Grimes, Ronald L. The Craft of Ritual Studies. Oxford: Oxford University Press, 2014.

Grimes, Ronald L. "Reinventing Ritual.” Soundings 75, no. 1 (1992): 21-41.

Grimes, Ronald L. Ritual Criticism: Case Studies in Its Practice, Essays on Its Theory. SCR. Columbia, SC: University of South Carolina Press, 1990.

Gunkel, Hermann. Die Wirkungen des Heiligen Geistes: Nach der populären Anschauung der Apostolichen Zeit und der Lehre des Apostels Paulus: Eine biblisch-theologische Studie. Göttingen: Vandenhoeck \& Ruprecht, 1899.

Guy, Laurie. "“Naked' Baptism in the Early Church: The Rhetoric and the Reality." JRH 27, no. 2, (2003): 133-42.

Hahn, Ferdinand. "Taufe und Rechtfertigung: Ein Beitrag zur paulinischen Theologie in ihrer Vor-und Nachgeschite." Pages 95-124 in Rechtfertigung: Festschrift für Ernst Käseamm. Edited by J. Friedrich et al. Tübingen: Mohr Siebeck, 1976.

Hansen, G. Walter. Abraham in Galatians: Expository and Rhetorical Contexts. Sheffield: JSOT Press, 1989.

Harrill, J. Albert. "Coming of Age and Putting on Christ: The Toga Virilis Ceremony, its Paraenesis, and Paul's Interpretation of Baptism in Galatians." NovT 44, no. 3 (2002): 252-77.

Harris, Murray J. Prepositions and Theology in the Greek New Testament: An Essential Reference Resource for Exegesis. Grand Rapids: Zondervan, 2012.

Harrisville, Roy A. "Before ПIETIE XPIETOY: The Objective Genitive as Good Greek." NovT 48 (2006): 353-88.

Harrisville, Roy A. "ПIETIE XPIETOY: Witness of the Fathers.” NovT 36 (1994): 233-41. 


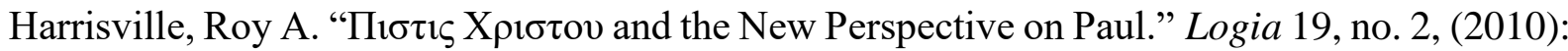
19-28.

Hartin, Patrick J. "The Letter of James: Faith Leads to Action (The Indicative Leads to the Imperative)." $W W$ 35, no. 3 (2015): 222-30.

Hartman, Lars. "Into the Name of the Lord Jesus": Baptism in the Early Church. Edinburgh: T\&T Clark, 1997.

Hartman, Lars. "Usages-Some Notes on the Baptismal Name-Formulae" Pages 397-413. Ablution, Initiation, and Baptism: Late Antiquity, Early Judaism, and Early Christianity. Edited by David Hellholm et al. Berlin: De Gruyter, 2011.

Hartvigsen, Kirsten Marie. "The Meal Formula, the Honeycomb, and Aseneth's Transformation." Pages 223-51 in The Eucharist-Its Origins and Contexts: Sacred Meal, Communal Meal, Table Fellowship in Late Antiquity, Early Judaism and Early Christianity, Volume I. Edited by David Hellholm and Dieter Sanger. Tübingen: Mohr Siebeck, 2017.

Hays, Richard B. The Faith of Jesus Christ: An Investigation of the Narrative Substructure of Galatians 3:1-4:11. SBLDS 56. Atlanta: Scholars Press, 1983.

Hays, Richard B. The Letter to the Galatians: Introduction, Commentary, and Reflections. NIB 11. Nashville: Abingdon Press, 2000.

Hays, Richard B. "What is 'Real Participation in Christ?"” Pages 336-51 in Redefining FirstCentury Jewish and Christian Identities: Essays in Honor of Ed Parish Sanders. Edited by Fabian E. Udoh et al. CJAS 16. Notre Dame: University of Notre Dame Press, 2008.

Hays, Richard B. " $\pi 1 \sigma \tau 1 \varepsilon$ and Pauline Christology: What Is at Stake." Pages 35-60 in Pauline Theology, Volume IV: Looking Back, Pressing On. Edited by Elizabeth Johnson and David M. Hay. Atlanta: Scholars Press, 1997.

Heitmüller, Wilhelm. "Im Namen Jesu“ Eine religionsgeschichtliche Untersuchung zum Neuen Testament. FRLANT 1.2. Göttingen: Vandenhoeck \& Ruprecht 1903.

Hellholm, David. "Vorgeformte Tauftraditionen und deren Benutzung in den Paulusbriefen." Pages 415-96 in Ablution, Initiation, and Baptism: Late Antiquity, Early Judaism, and Early Christianity. Edited by David Hellholm et al. Berlin: De Gruyter, 2011.

Hewitt, J. Thomas. "In Messiah: Messiah Discourse in Ancient Judaism and 'In Christ' Language in Paul.” Ph.D. diss., University of Edinburgh, 2019.

Hewitt, J. Thomas and Matthew V. Novenson. "Participationism and Messiah Christology in Paul." Pages 352-71 in God and the Faithfulness of Paul: A Critical Examination of the Pauline Theology of N. T. Wright. Edited by Christoph Heilig et al. WUNT II 413. Tübingen: Mohr Siebeck, 2016.

Hoehner, Harold W. Ephesians : an Exegetical Commentary. Harold W. Hoehner. Grand Rapids, Mich: Baker Academic, 2002.

Hofius, Otfried. "The Lord's Supper and the Lord's Supper Tradition: Reflections on 1 Corinthians 11:23b-25." Pages 83-88 in One Loaf, One Cup: Ecumenical Studies of 1 
Cor 11 and Other Eucharistic Texts. The Cambridge Conference on the Eucharist August 1988. Edited by B. F. Meyer. Leuven: Peeters Press, 1993.

Honko, Lauri. “Theories Concerning the Ritual Process: An Orientation.” Pages 369-90 in Science of Religion: Studies in Methodology. Edited by Lauri Honko. Religion and Reason 13. The Hague: Mouton, 1979.

Horn, F. W. Das Angeld des Geistes: Studien zur paulinischen Pneumatologie. FRLANT 154. Göttingen: Vandenhoeck \& Ruprecht, 1992.

Horrell, David G. "Domestic Space and Christian Meetings at Corinth: Imagining New Contexts and the Buildings East of the Theatre." NTS 50, no. 3 (2004): 349-69.

Horrell, David G. The Social Ethos of the Corinthian Correspondence: Interest and Ideology from 1 Corinthians to 1 Clement. Studies of the New Testament and Its World. Edinburgh: T\&T Clark, 1996.

Houseman, Michael. "Relationality." Pages 413-28 in Theorizing Rituals, Volume 1: Issues, Topics, Approaches, Concepts. Edited by Jens Kreinath et al. Numen Book Series 114. Leiden: Brill, 2006.

Howard, George. Paul: Crisis in Galatia: A Study in Early Christian Theology. 2d ed. SNTSMS 35. Cambridge: Cambridge University Press, 1990.

Hubbard, Mell. New Creation in Paul's Letters and Thought. SNTSMS 119. Cambridge: Cambridge University Press, 2002.

Hubert, Henri, and Marcel Mauss. Sacrifice: Its Nature and Function. Translated by W. D. Halls. London: Cohen \& West, 1964.

Hultgren, Arland J. Paul's Letter to the Romans: A Commentary. Grand Rapids: Eerdmans, 2011.

Hultgren, Arland J. "The Pistis Christou Formulation in Paul." NovT 22, no. 3 (1980): 248-63.

Hurtado, Larry. One God, One Lord: Early Christian Devotion and Ancient Jewish Monotheism. Philadelphia: Fortress, 1988.

Jackson, T. Ryan. New Creation in Paul's Letters. Tübingen: Mohr Siebeck, 2010.

Jamir, Lanuwabang. "Exclusion and Judgment in Fellowship Meals: The Sociohistorical Background of 1 Corinthians 11:17-34." Ph.D. diss., Middlesex University, supervised at London School of Theology, 2012.

Jense, Adolf E. Myth and Cult among Primitive Peoples. Translated by Marianna Tax Choldin and Wolfgang Weissleder. Chicago: University of Chicago Press, 1973.

Jeremias, Joachim. The Eucharistic Words of Jesus. 3d ed. Translated by Norman Perrin. London: SCM Press. 1966.

Jewett, Robert. Romans: A Commentary. Minneapolis: Fortress Press, 2007.

Johnson, Luke Timothy. Religious Experience in Earliest Christianity: A Missing Dimension in New Testament Studies. Minneapolis: Fortress Press, 1998.

Johnson, Maxwell E. The Rites of Christian Initiation: Their Evolution and Interpretation. Collegeville, MN: The Liturgical Press, 1999. 
Johnson Hodge, Caroline. If Sons, Then Heirs: A Story of Kinship and Ethnicity in the Letters of Paul. Oxford: Oxford University Press, 2008.

Jonge, Henk Jan de. "The Early History of the Lord's Supper." Pages 209-37 in Religious Identity and the Invention of Tradition. Edited by Jan Willem van Henten and Anton Houtepen. Assen, Netherlands: Royal Van Gorcum, 2001.

Jonge, Henk Jan de. "Koinonia, Koinonoi and Metechein in Paul's Prohibition of Christian Participation in Pagan Cultic Meals (1 Cor 10:14-22)." Pages 45-60 in Paul-Werk und Wirkung: Festschrift für Abdreas Lindemann zum 70. Edited by Paul-Gerard Klumbies and David S. du Toit. Tübingen: Mohr Siebeck, 2013.

Kapferer, Bruce "Virtuality." Pages 671-84 in Theorizing Rituals, Volume 1: Issues, Topics, Approaches, Concepts. Edited by Jens Kreinath et al. Numen Book Series 114. Leiden: Brill, 2006.

Kase, Vojtech. "Meal Practices." Pages 409-25 in The Oxford Handbook of Early Christian Ritual. Edited by Risto Uro et al. Oxford: Oxford University Press, 2019.

Käsemann, Ernst. Commentary on Romans. Translated by G. W. Bromiley. Grand Rapids: Eerdmans, 1980.

Käsemann, Ernst. Perspectives on Paul. Translated by Margaret Kohl. NTL. Edinburgh: SCM Press, 1971.

Keating, J. F. The Agape and the Eucharist in the Early Church: Studies in the History of the Christian Love-Feasts. 1901. Repr., New York: AMS Press, 1969.

Keener, Craig S. Galatians: A Commentary. Grand Rapids: Baker Academic, 2019.

Kennedy, H. A. A. St. Paul and the Mystery Religions. London: Hodder \& Stoughton, 1914.

Kim, Jung Hoon. The Significance of Clothing Imagery in the Pauline Corpus. JSNTSup 268. London: T\&T Clark, 2004.

Kim, Seyoon. The Origin of Paul's Gospel. Tübingen: Paul Siebeck, 1981.

Kim, Seyoon. Paul and the New Perspective: Second Thoughts on the Origin of Paul's Gospel Grand Rapids: Eerdmans, 2002.

Kister, M. "Demons, Theology and Abraham's Covenant (CD XVI, 4-6 and Related Texts)." Pages 167-84 in The Dead Sea Scrolls at Fifty: Proceeding of the 1997 SBL Qumran Section Meetings. Edited by R. A. Kugler and E. M. Schuller. Atlanta: Scholars Press, 1999.

Kittel, Gerhard, and Gerhard Friedrich, eds. Theological Dictionary of the New Testament. Translated by Geoffrey W. Bromiley. 10 vols. Grand Rapids: Eerdmans, 1964-1976.

Kitty, Eva Feder. Metaphor: Its Cognitive Force and Linguistic Structure. Oxford: Clarendon Press, 1987.

Klauck, Hans-Josef. "Present in the Lord's Supper: 1 Corinthians 11:23-26 in the Context of Hellenistic Religious History." Pages 65-66 in One Loaf, One Cup: Ecumenical Studies of 1 Cor 11 and Other Eucharistic Texts: The Cambridge Conference on the Eucharist August 1988. Edited by B. F. Meyer. Leuven: Peeters Press, 1993. 
Klauck, Hans-Josef. The Religious Context of Early Christianity: A Guide to Graeco-Roman Religions. Translated by Brian McNeil. Edinburgh: T\&T Clark, 2000.

Klawans, Jonathan. Purity, Sacrifice, and the Temple: Symbolism and Supersessionism in the Study of Ancient Judaism. Oxford: Oxford University Press, 2006.

Klingbeil, Gerald A. Bridging the Gap: Ritual and Ritual Texts in the Bible. Winona Lake, IN: Eisenbrauns, 2007.

Kloppenborg, John S. "Greco-Roman Thiasoi, the Ekklesia at Corinth, and Conflict Management." Pages 187-218 in Redescribing Paul and the Corinthians. Edited by Ron Cameron and Merrill P. Miller. ECIL 5. Atlanta: SBL, 2011.

Koch, Dietrich-Alex. "The Early History of the Lord's Supper: Response to Henk Jan de Jonge.' Pages 238-52 in Religious Identity and the Invention of Tradition. Edited by Jan Willem van Henten and Anton Houtepen. Assen, The Netherlands: Royal Van Gorcum, 2001.

Konstan, David. “Trusting in Jesus.” JSNT 40, no. 3 (2018): 247-54.

Kuhn, Karl Georg. "The Lord's Supper and the Communal Meal at Qumran." Pages 65-93 in The Scrolls and the New Testament. Edited by Krister Stendahl. New York: Crossroad, 1992.

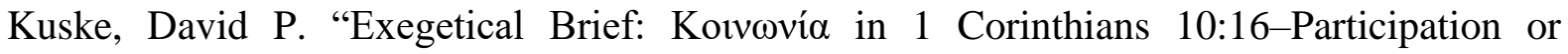
Partnership?" Wisconsin Lutheran Quarterly 101, no. 4 (2004): 284-86.

Lakey, Michael. The Ritual World of Paul the Apostle: Metaphysics, Community and Symbol in 1 Corinthians 10-11. LNTS 602. London: T\&T Clark, 2019.

Lakoff, George and Mark Johnson. Metaphors We Live By. Chicago: University of Chicago Press, 1980.

Lampe, G. W. H. The Seal of the Spirit: A Study in the Doctrine of Baptism and Confirmation in the New Testament and the Father. 2d ed. London: SPCK, 1967.

Lampe, Peter. "The Corinthian Dinner Party: Exegesis of a Cultural Context (1 Cor. 11:1734)." Affirmation 4/2 (1991): 1-15.

Lampe, Peter. "The Eucharist: Identifying with Christ on the Cross." Interpretation 48 (1994): $36-49$.

Lanternari, Vittorio. "La Grande Festa": Vita ritual e sistemi di produzione nelle societa tradizionali. 2d ed. Bari: Edizioni Dedalo, 2004.

Lathrop, Gordon. "The Origins and Early Meanings of Christian Baptism: A Proposal.” Worship 68, no. 6 (1994): 504-22.

Lawson, E. Thomas and Robert N. McCauley. Rethinking Religion: Connecting Cognition and Culture. Cambridge: Cambridge University Press, 1990.

Leeuw, Gerardus van der. "Die do-ut-des-Formel in der Opfertheorie." AR 20 (1920-1921): 241-53.

Léon-Dufour, Xavier. Sharing the Eucharistic Bread: The Witness of the New Testament. New York: Paulist Press, 1987.

Lévi-Strauss, Claude, Totemism. Translated by Rodney Needham. Boston: Beacon Press, 1962. 
Lietzmann, Hans. Mass and Lord's Supper: A Study in the History of the Liturgy. Translated by Dorothea H. G. Reeve. Edited by Robert D. Richardson. Leiden: Brill, 1979.

Lightfoot, J. B. St. Paul's Epistle to the Galatians: A Revised Text. Rev. ed. London: Macmillan, 1865.

Lincoln, Andrew T. Word Biblical Commentary. Andrew T. Lincoln. Waco, Tex: Word Books, 1990.

Lindemann, Andreas, Der Erste Korintherbrief: Handbuck zum Neuen Testament 9/I. Tübingen: Mohr Siebeck, 2000.

Lindsay, Dennis R. "The Roots and Development of the $\pi \imath \sigma \tau-$ Word Group as Faith Terminology." JSNT 15, no. 49 (1993): 103-18.

Litwa, M. David. We Are Being Transformed. 1. Aufl. ed. BZNW 187. Berlin: De Gruyter, 2012.

Llewelyn, S. R. "The Use of Sunday for Meetings of Believers in the New Testament." NovT 43, no. 3 (2001): 205-23.

Lohse, Eduard. A Commentary on the Epistles to the Colossians and to Philemon. Translated by William R. Poehlmann and Robert J. Karris. Philadelphia, Fortress Press, 1971.

Lohse, Eduard. “Taufe und Rechtfertigung bei Paulus.” Kerygma und Dogma 11 (1965): 30824. Repr. in pages 228-44 in Die Einheit des Neuen Testaments: Exegetische Studien zur Theologie das Neuen Testaments. Göttingen: Vendenhoeck \& Ruprecht, 1973.

Longenecker, Richard N. Word Biblical Commentary. Volume 41, Galatians. Dallas: Word Books, 1990.

Lührmann, Dieter. "Wo man nicht Sklave oder Freier ist: Überlegungen zur Struktur früchristlicher Gemeinden." WD 13 (1975): 53-83.

Macaskill, Grant. Union with Christ in the New Testament. Oxford: Oxford University Press, 2013.

Mack, Burton L. "Rereading the Christ Myth: Paul's Gospel and the Christ Cult Question." Pages 35-73 in Redescribing Paul and the Corinthians. Edited by Ron Cameron and Merill P. Miller. ECIL 5. Atlanta: SBL, 2011.

Malina, Bruce J. "The Social Sciences and Biblical Interpretation." Interpretation: A Journal of Bible and Theology 36, no. 3, 1982: 229-42.

Marsh, Thomas. Gift of Community: Baptism and Confirmation. Wilmington, DE: Michael Glazier, 1984.

Martin, Dale B. The Corinthian Body. New Haven: Yale University Press, 1995.

Martin, Luther H. "Initiation." Pages 334-52 in The Oxford Handbook of Early Christian Ritual. Edited by Risto Uro et al. Oxford: Oxford University Press, 2019.

Martin, Ralph P. "Patterns of Worship in New Testament Churches." JSNT 12, no. 37 (1989): 59-85.

Martyn, J. Louis. Galatians: A New Translation, with Introduction and Commentary. New York: Doubleday, 1998. 


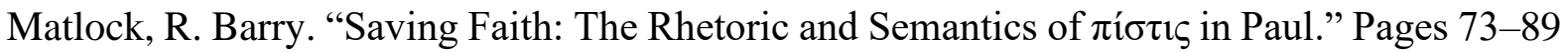
in The Faith of Jesus Christ: Exegetical, Biblical, and Theological Studies. Edited by Michael F. Bird and Preston M. Sprinkle. Peabody, MA. Hendrickson, 2009.

McDonnell, Kilian, and George T. Montague. Christian Initiation and Baptism in the Holy Spirit: Evidence from the First Eight Centuries. 2d ed. Collegeville, MN: The Liturgical Press, 1994.

McGowan, Andrew B. Ancient Christian Worship: Early Church Practices in Social, Historical, and Theological Perspective. Grand Rapids: Baker Academic, 2014.

McGowan, Andrew B. Ascetic Eucharists: Food and Drink in Early Christian Ritual Meals Oxford: Clarendon Press, 1999.

McGowan, Andrew B. “'Is There a Liturgical Text in This Gospel?' The Institution Narratives and Their Early Interpretive Communities." JBL 118, no. 1 (1999): 73-87.

McKenna, John H. "Eucharist and Sacrifice: An Overview." Worship 76, no. 5, 2002: 386402.

Meeks, Wayne A. The First Urban Christians: The Social World of the Apostle Paul. 2d ed. New Haven: Yale University Press, 1983.

Meeks, Wayne A. "The Image of the Androgyne: Some Uses of a Symbol in Earliest Christianity." HR 13 (1974): 165-208.

Metzger, B. M. "Considerations of Methodology in the Study of the Mystery Religions and Early Christianity.” HTR 48 (1955): 1-20.

Meyer, Marvin W. "Mystery Religions." Pages 941-944 in The Anchor Bible Dictionary. Vol. 4. Edited by David Noel Freedman. New York: Doubleday, 1992.

Michael, Otto. Der Brief an die Römer. $14^{\text {th }}$ ed. KEK 4. Göttingen: Vandenhoeck \& Ruprecht, 1978.

Milgrom, Jacob. Leviticus 1-16: A New Translation, with Introduction and Commentary. New York: Doubleday, 1991.

Milgrom, Jacob. Leviticus 17-22: A New Translation, with Introduction and Commentary. New York: Doubleday, 2000.

Milgrom, Jacob. Leviticus 23-27: A New Translation, with Introduction and Commentary. New York: Doubleday, 2001.

Miller, Douglas B. “The Nature of Biblical Faith.” Direction 44, no. 1 (2015): 72-83.

Mitchell, Margaret M. Paul and the Rhetoric of Reconciliation. Tübingen: Mohr Siebeck, 1992.

Montanari, Franco. The Brill Dictionary of Ancient Greek. Leiden: Brill, 2015.

Moo, Douglas J. Galatians. Grand Rapids: Baker Academic, 2013.

Moo, Douglas. Romans 1-8: The Wycliffe Exegetical Commentary. Chicago: Moody, 1991.

Morales, Isaac Augustine. "Baptism and Union with Christ." Pages 157-79 in "In Christ" in Paul: Explorations in Paul's Theology of Union and Participation. Edited by Michael J. Thate et al. Tübingen: Mohr Siebeck, 2014. 
Morgan, Teresa. Roman Faith and Christian Faith: Pistis and Fides in the Early Roman Empire and Early Churches. Oxford: Oxford University Press, 2015.

Morris, Leon. The Epistle to the Romans. Grand Rapids: Eerdmans, 1988.

Mosser, Carl. "The Earliest Patristic Interpretations of Psalm 82, Jewish Antecedents, and the Origin of Christian Deification.” JTS 56, no. 1 (2005): 30-74.

Moulton, James Hope. Vocabulary of the Greek Testament Illustrated from the Papyri and Other Non-literary Sources. London: Hodder \& Stoughton, 1901.

Murphy-O'Connor, Jerome, "Eucharistic and Community in First Corinthians." Pages 1-30 in Living Bread, Saving Cup: Readings on the Eucharist. Edited by R. Kevin Seasoltz. Collegeville, MN: Liturgical Press, 1982.

Murphy-O'Connor, Jerome. New Jerome Biblical Commentary. ed. R. E. Brown et al. Englewood Cliffs, NJ: Prentice Hall, 1990.

Murray, John. The Epistle to the Romans: The English Text with Introduction, Exposition, and Notes. NICNT. London: Marshall, Morgan \& Scott, 1959. Repr., Grand Rapids: Eerdmans, 1997.

Mussner, Franz. Der Galaterbrief. 5th ed. HTKNT 9. Freiburg: Herder, 1988.

Nagy, Gregory. “Can Myth Be Saved.” Pages 240-48 in Myth: A New Symposium. Edited by Gregory Schrempp and William Hansen. Bloomington: University of Indiana Press, 2000.

Nanos, Mark D. "The Inter- and Intra-Jewish Political Context of Paul's Letter to the Galatians." Pages 396-407 in The Galatians Debate: Contemporary Issues in Rhetorical and Historical Interpretation. Edited by Mark D. Nanos. Peabody, MA: Hendrickson, 2002.

Neugebauer, Fritz. "Das Paulinische 'in Christo." New Testament Studies 4, no. 2, (1958): 124-38.

Neusner, Jacob. "The Conversion of Adiabene to Judaism: A New Perspective." Journal of Biblical Literature 83, no. 1 (1964): 60-66.

Newton, Michael. The Concept of Purity at Qumran and in the Letters of Paul. Cambridge: Cambridge University Press, 1985.

Nock, A. D. "Hellenistic Mysteries and Christian Sacraments." Pages 791-820 in Essays on Religion and the Ancient World. Edited by Z. Stewart. 2 vols. Oxford: Clarendon Press, 1972.

Nuffelen, Peter van. Rethinking the Gods: Philosophical Readings of Religion in the PostHellenistic Period. Cambridge: Cambridge University Press, 2011.

O'Brien, Peter Thomas. The Letter to the Ephesians. Peter T. O'Brien. Grand Rapids, Mich: Eerdmans, 1999.

O'Donnell, Matthew Brook. "Two Opposing Views on Baptism With/By the Holy Spirit and of 1 Corinthians 12.13: Can Grammatical Investigation Bring Clarity?" Pages 311-36 in Baptism, the New Testament and the Church: Historical and Contemporary Studies 
in Honour of R. E. O. White. Edited by Stanley E. Porter and Anthony R. Cross. JSNTSup 171. Sheffield: Sheffield Academic Press, 1999.

Orr, David G. "Roman Domestic Religion: The Evidence of the Household Shrines." ANRW 2.16.2: 1557-91 (1978).

Parker, Robert. Miasma: Purification and Pollution in Early Greek Religion. Oxford: Clarendon Press, 1983.

Patterson, Jane Lancaster. Keeping the Feast: Metaphors of Sacrifice in 1 Corinthians and Philippians. Atlanta: SBL Press, 2015.

Paulsen, Henning. "Einheit und Freiheit der Söhne Gottes: Gal 3:26-29.” ZNW 71 (1980): 74 95.

Pearson, Brook W. R. "Baptism and Initiation in the Cult of Isis and Sarapis." Pages 42-62 in Baptism, the New Testament and the Church: Historical and Contemporary Studies in Honour of R.E.O. White. Edited by Stanley E. Porter and Anthony R. Cross. JSNTSup 171. Sheffield, Sheffield Academic Press, 1999.

Penna, Romano. Paul the Apostle: Jew and Greek Alike: A Theological and Exegetical Study, Volume 1. Translated by Thomas P. Wahl. Collegeville, MN: The Liturgical Press, 1996.

Perkins, Pheme. First Corinthians. Paideia. Grand Rapids, Michigan: Baker Academic, a Division of Baker Publishing Group, 2012.

Perkins, Pheme, "Ritual and Orthodoxy." Pages 503-19 in The Oxford Handbook of Early Christian Ritual. Edited by Risto Uro et al. Oxford: Oxford University Press, 2019.

Petersen, Anders Klostergaard. "Ritual and Texts." Pages 370-87 in The Oxford Handbook of Early Christian Ritual. Edited by Risto Uro et al. Oxford: Oxford University Press, 2019.

Petersen, Anders K. "Rituals of Purification, Rituals of Initiation: Phenomenological, Taxonomical and Culturally Evolutionary Reflections." Pages 3-40 in Ablution, Initiation, and Baptism: Late Antiquity, Early Judaism, and Early Christianity. Edited by David Hellholm et al. Berlin: De Gruyter, 2011.

Pfitzner, Victor C. "Proclaiming the Name: Cultic Narrative and Eucharistic Proclamation in First Corinthians." LTJ 25 (1991): 15-25.

Porter, Stanley E. Idioms of the Greek New Testament. 2d ed. Sheffield: Sheffield Academic Press, 1994.

Power, David Noel. The Eucharistic Mystery: Revitalizing the Tradition. New York: Crossroad, 1994.

Prothro, James B. Both Judge and Justifier: Biblical Legal Language and the Act of Justifying in Paul. Tübingen: Mohr Siebeck, 2018.

Quinn, Frank “Confirmation Reconsidered: Rite and Meaning.” Worship 59 (1985): 354-70.

Rabens, Volker. The Holy Spirit and Ethics in Paul: Transformation and Empowering for Religious-Ethical life. WUNT II 283. Tübingen: Mohr Siebeck, 2010. 
Rahner, Hugo. "The Christian Mystery and the Pagan Mysteries. Pages 387-401 in The Mysteries: Papers from the Eranos Yearbooks, Vol. 2. Edited by J. Campbell. Bollingen Series 30. Princeton: Princeton University Press, 1955.

Rappaport, Roy A. Ritual and Religion in the Making of Humanity. Cambridge Studies in Social and Cultural Anthropology 110. Cambridge: Cambridge University Press, 1999.

Reitzenstein, Richard. Hellenistic Mystery-Religions: Their Basic Ideas and Significance. Translated by J. Steely. Pittsburgh: Pickwick Press, 1978.

Ridderbos, Herman N. Paul: An Outline of His Theology. Translated by John Richard De Witt. Grand Rapids: Eerdmans, 1997.

Ridgeway, William. "The Dramas and Dramatic Dances of Non-European Races." Pages 35978 in The Myth and Ritual Theory: An Anthology. Edited by Robert E. Segal. London: Wiley, 1998.

Roitto, Rikard. "Paul's Theological Language of Salvation as Social and Embodied Cognition." Pages 371-99 in Participation, Justification, and Conversion: Eastern Orthodox Interpretation of Paul and the Debate Between "Old and New Perspectives on Paul." Edited by Athanasios Despotis. WUNT II 442. Tübingen: Mohr Siebeck, 2017.

Rouwhorst, G. A. M. De viering van de eucharistie in de vroege kerk. Utrecht: Katholieke Theologische Universiteit, 1992.

Ruel, Malcolm. "Christians as Believers." Pages 242-64 in Ritual and Religious Belief: A Reader. Edited by Graham Harvey. London: Equinox, 2005.

Saliba, John A. Mircea Eliade: An Anthropological Evaluation. Leiden: E. J. Brill, 1976.

Sanders, E. P. Paul and Palestinian Judaism: A Comparison of Patterns of Religion. Minneapolis: Fortress, 1977.

Sax, William S. "Ritual and the Problem of Efficacy." Pages 3-16 in The Problem of Ritual Efficacy. Edited by William S. Sax et al. Oxford: Oxford University Press, 2010.

Schieffelin, Edward. "On Failure and Performance: Throwing the Medium out of the Séance." Pages 59-89 in The Performance of Healing. Edited by Carol Laderman and Marina Roseman. London: Routledge, 1996.

Schieffelin, Edward. "Participation." Pages 615-25 in Theorizing Rituals, Volume 1: Issues, Topics, Approaches, Concepts. Edited by Jens Kreinath et al. Numen Book Series 114. Leiden: Brill, 2006.

Schjodt, Jens Peter. "Initiation and the Classification of Rituals." Temenos 22 (1986): 93-108.

Schließer, Benjamin. Abraham's Faith in Romans 4. WUNT II 224. Tübingen: Mohr Siebeck, 2007.

Schliesser, Benjamin. “"Christ-Faith' as an Eschatological Event (Galatians 3.23-26): A 'Third

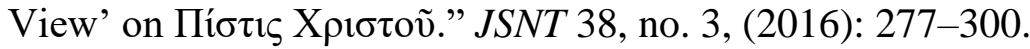

Schmithals, Walther. Paul and the Gnostics. Nashville: Abingdon Press, 1972.

Schnackenburg, Rudolf. Baptism in the Thought of St. Paul. Translated by G. R. BeasleyMurray. Oxford: Basil Blackwell, 1964. 
Schnelle, Udo. Gerechtigkeit und Christusgegenwart: Vorpaulinische und paulinische Tauftheologie. 2d ed. GTA 24. Göttingen: Vandenhoeck \& Ruprecht, 1985.

Schottroff, W. Gedenken Im Alten Orient und im Alten Testament. Neukirchen-Vluyn: Neukirchener Verlag, 1964.

Schulz, Celia E. Women's Religious Activity in the Roman Republic. Chapel Hill: University of North Carolina Press, 2006.

Schürmann, Heinz. Eine quellenkritische Untersuchung des lukanischen Abendmahlsberichtes LK 22, 7-38, II Teil. Aschendorf: Münster, 1955.

Schweitzer, Albert. The Mysticism of Paul the Apostle. Translated by William Montgomery. London: Adam and Charles Black, 1953.

Schweitzer, Albert. Paul and His Interpreters: A Critical History. Translated by William Montgomery. London: Adam and Charles Black, 1912.

Scroggs, Robin. "Paul and the Eschatological Woman Revisited." JAAR 42, no. 3: 532-37.

Searle, J. R. Speech Acts. Cambridge: Cambridge University Press, 1969.

Seesemann, Heinrich. Der Begriff KOINSNIA Im Neuen Testament. BZNW 14. Alfred Töpelman, Giessen: 1933.

Segal, Robert A. "Myth and Ritual." Pages 101-21 in Theorizing Rituals: Issues, Topics, Approaches, Concepts. Edited by Jens Kreinath et al. Numen Book Series 114. Leiden: Brill, 2006.

Selby, Gary S. “(Em)Bodying the Faith: Baptism as Ritual Communication.” Res $Q$ 48, no. 1 (2006): 1-10.

Siegert, F. Argumentation bei Paulus, gezeigt an Röm 9-11. BZNW 34. Tübingen: Mohr Siebeck, 1985.

Smith, Dennis E. From Symposium to Eucharist: The Banquet in the Early Christian World. Minneapolis: Fortress Press, 2003.

Smith, Dennis E. "Meal Customs.” Pages 653-54 in The Anchor Bible Dictionary. Vol. 4. Edited by David Noel Freedman. New York: Doubleday, 1992.

Smith, Jonathan Z. Drudgery Divine: On the Comparison of Early Christianities and the Religions of Late Antiquity. London: Routledge, 1990.

Smith, W. Robertson. Lectures on the Religion of the Semites: The Fundamental Institutions. 3d ed. Repr. New York: Ktav Publishing House, 1969.

Smyth, Herbert Weir. Greek Grammar. Cambridge: Harvard University Press, 1920.

Snaith, Norman H. The Jewish New Year Festival: Its Origins and Development. Eugene, OR: Wipf \& Stock, 1947.

Snoek, Jan A. M. "Defining 'Rituals." Pages 3-14 in Theorizing Rituals: Issues, Topics, Approaches, Concepts. Edited by Jens Kreinath et al. Numen Book Series 114. Leiden: Brill, 2006.

Soards, M. L. 1 Corinthians: New International Commentary. Peabody, MA: Hendrickson, 1999. 
Söding, Thomas. "Kreuzestheologie und Rechtfertigungslehre: Zur Verbindung von Christologie und Soteriologie im Ersten Korintherbrief und im Galaterbrief." Pages 153-82 in Das Wort vom Kreuz: Studien zur paulinischen Theologie. BZNW 93. Tübingen: Mohr Siebeck, 1997.

Sourvinou-Inwood, Christiane, "Festival and Mysteries: Aspects of the Eleusinian Cult." Pages 25-41 in Greek Mysteries: The Archaeology and Ritual of Ancient Greek Secret Cults. Edited by Michael B. Cosmopoulos. New York: Routledge, 2003.

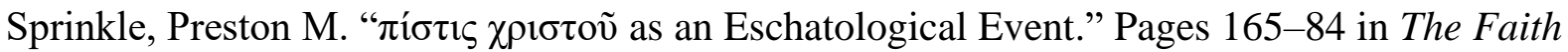
of Jesus Christ: Exegetical, Biblical, and Theological Studies. Edited by Michael F. Bird and Preston M. Sprinkle. Peabody, Mass.: Hendrickson, 2009.

Staal, Frits. “The Meaninglessness of Ritual.” Numen 26, no. 1 (1979): 2-22.

Stanley, Christopher D. "Neither Jew nor Greek': Ethnic Conflict in Graeco-Roman Society." JSNT 19, no. 64 (1996): 101-24.

Stephenson, Barry. "Ritual as Action, Performance, and Practice." Pages 38-55 in The Oxford Handbook of Early Christian Ritual. Edited by Risto Uro et al. Oxford: Oxford University Press, 2019.

Stiver, Dan R. The Philosophy of Religious Language: Sign, Symbols, and Story. Malden, MA: Blackwell, 1996.

Stommel, Eduard. “'Begraben mit Christus' (Röm. 6,4) und der Taufritus.” $R Q 49$ (1954): 120.

Story, J. Lyle. "Facets of Faith/Trust in Pauline Thought." American Theological Inquiry 5, no. 1, (2012): 101-15.

Stott, John R. W. Baptism and Fullness: The Work of the Holy Spirit Today. 2d ed. Downers Grove, IL: InterVarsity Press, 1975.

Stott, John R. W. The Message of Romans: God's Good News for the World. Downers Grove, IL: InterVarsity Press, 1994.

Stowers, Stanley K. "Kinds of Myth, Meals, and Powers: Paul and the Corinthians." Pages 105-49 in Redescribing Paul and the Corinthians. Edited by Ron Cameron and Merrill P. Miller. ECIL 5. Atlanta: SBL, 2011.

Stowers, Stanley K. "Does Pauline Christianity Resemble a Hellenistic Philosophy?” Pages 219-43 in Redescribing Paul and the Corinthians. Edited by Ron Cameron et al. ECIL 5. Atlanta: SBL, 2011.

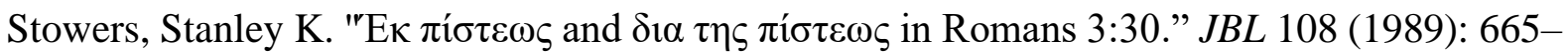
74.

Strecker, Christian. Die liminale Theologie des Paulus: Zugange zur paulinischen Theologie aus kulturanthropologischer Perspecktive. FRLANT 185. Göttingen: Vandenhoeck \& Ruprecht, 1999.

Tannehill, Robert. Dying and Rising with Christ: A Study in Pauline Theology. BZNW 32. Berlin: Töpelmann, 1967. 
Taussig, Hal. In the Beginning Was the Meal: Social Experimental and Early Christian Identity. Minneapolis: Fortress Press, 2009.

Taussig, Hal. "Steps Forward in the Study of Early Christian Ritual Life." Pages 183-196 in Early Christian Ritual Life. Edited by Richard E. DeMaris et al. London: Routledge, 2017.

Taylor, N. H. "Dying with Christ in Baptism: Issues in the Translation and Interpretation of Romans 6.3-4." BT 59, no. 1 (2008): 38-49.

Theissen, Gerd. The Social Setting of Pauline Christianity. Translated by John H. Schütz. Edinburgh: T\&T Clark, 1982.

Thiselton, Anthony C. The First Epistle to the Corinthians : A Commentary on the Greek Text. New International Greek Testament Commentary. Grand Rapids, Mich. : Carlisle: Eerdmans ; Paternoster Press, 2000.

Turley, Stephen Richard. The Ritualized Revelation of the Messianic Age: Washing and Meals in Galatians and 1 Corinthians. JSNTSup 544. Bloomsbury: T\&T Clark, 2015.

Turner, Edith. "The Literary Roots of Victor Turner's Anthropology." Pages 163-69 in Victor Turner and the Construction of Cultural Criticism: Between Literature and Anthropology. Edited by Kathleen M. Ashley. Bloomington: Indiana University Press, 1990.

Turner, Nigel. Grammatical Insights into the New Testament. Bloomsbury Academic Collections. London: Bloomsbury, 2015.

Turner, Victor W. "African Rituals and Western Literature: Is a Comparative Symbology Possible?" Pages 45-81 in The Literature of Fact: Selected Papers from the English Institute. Edited by Angus Fletcher. New York: Columbia University Press, 1976.

Turner, Victor W. Dramas, Fields, and Metaphors: Symbolic Action in Human Society. NY: Cornell University Press, 1974.

Turner, Victor W. The Ritual Process: Structure and Anti-Structure. Chicago: Aldine, 1969.

Tylor, E. B. Primitive Culture: Researches into the Development of Mythology, Philosophy, Religion. 2 vols. Repr. Gloucester, MA: Peter Smith, 1970.

Uro, Risto. "Introduction: Ritual in the Study of Early Christianity." Pages 3-17 in The Oxford Handbook of Early Christian Ritual. Edited by Risto Uro, Juliette J. Day, Richard DeMaris, and Rikard Roitto. Oxford: Oxford University Press, 2019.

Uro, Risto. Ritual and Christian Beginnings: A Socio-Cognitive Analysis. Oxford: Oxford University Press, 2016.

Uzukwu, Gesila Nneka. The Unity of Male and Female in Jesus Christ: An Exegetical Study of Galatians 3.28c in Light of Paul's Theology of Promise. LNTS 531. London: Bloomsbury T\&T Clark, 2015.

van Kooten, G.H, "Pagan and Jewish Monotheism According to Varro, Plutarch and St Paul: The Aniconic, Monotheistic Beginnings of Rome's Pagan Cult - Romans 1.19-25 in a Roman Context." Pages 633-51 in Flores Florentino. Vol 122. Martinus Nijhoff/Brill, 2007 
Vearncombe, Erin K. "Rituals for Communal Maintenance.” Pages 92-112 in Early Christian Ritual Life. Edited by Richard E. DeMaris et al. London: Routledge, 2017.

Vegge, Tor. "Baptismal Phrases in the Deuteropauline Epistles." Pages 497-556 in Ablution, Initiation, and Baptism: Late Antiquity, Early Judaism, and Early Christianity. Edited by David Hellholm et al. Berlin: De Gruyter, 2011.

Villeneuve, Andre. Nuptial Symbolism in Second Temple Writings, the New Testament, and Rabbinic Literature: Divine Marriage at Key Moments of Salvation History. Ancient Judaism and Early Christianity 92. Leiden: Brill, 2016.

Wagner, Günter. Pauline Baptism and the Pagan Mysteries. Translated by J. P. Smith. Edinburgh: Oliver \& Boyd, 1967.

Wainwright, Geoffrey. Ecumenical Studies in History 10. Christian Initiation. Richmond, VA: John Knox Press, 1969.

Wallis, Ian G. The Faith of Jesus of Christ in Early Christian Traditions. SNTSMS 84. Cambridge: Cambridge University Press, 1995.

Wardle, Timothy. "Who is Sacrificing? Assessing the Early Christian Reticence to Transfer the Idea of the Priesthood to the Community." Pages 99-114 in Ritual and Metaphor: Sacrifice in the Bible. Edited by Christian A. Eberhart. Atlanta: SBL, 2011.

Warnach, Viktor. "Taufe und Christusgeschehen nach Römer 6.” ALW 3 (1954): 284-366.

Watson, Francis, "Quaestiones Disputatae: Roman Faith and Christian Faith." NTS 64, no. 2 (2018): 243-47.

Watts, James W. "The Rhetoric of Sacrifice.” Pages 3-16 in Ritual and Metaphor: Sacrifice in the Bible. Edited by Christian A. Eberhart. Atlanta: SBL, 2011.

Wedderburn, A. J. M. Baptism and Resurrection: Studies in Pauline Theology against its Graeco-Roman Background. Tübingen: Mohr Siebeck, 1987.

Wedderburn, A. J. M. "The Body of Christ and Related Concepts in 1 Corinthians." SJT 24 (1971): 74-96.

Wedderburn, A. J. M. "Hellenistic Christian Traditions in Romans 6.” NTS 29, no. 3 (1983): 337-55.

Wedderburn, A. J. M. "The Soteriology of the Mysteries and Pauline Baptismal Theology." NovT 29, no 1. (1987): 53-72.

Wikenhauser, Alfred. Pauline Mysticism: Christ in the Mystical Teaching of St Paul. Translated by Joseph Cunningham. New York: Herder \& Herder, 1960.

Wilckens, Ulrich. Der Brief an die Römer, Volume 2. EKKNT 6. Zurich: Benziger, 1978.

Winninge, Mikael. "The Lord's Supper in 1 Cor 11 and Luke 22: Traditions and Development." Pages 579-602 in The Eucharist-Its Origins and Contexts: Sacred Meal, Communal Meal, Table Fellowship in Late Antiquity, Early Judaism and Early Christianity, Volume I. Edited by David Hellholm and Dieter Sanger. Tübingen: Mohr Siebeck, 2017.

Witherington, Ben. "Rite and Rights for Women—Galatians 3:28.” NTS 27, no. 5 (1981): 593604. 
Wolter, Michael. Paul: An Outline of His Theology. Trans. Robert Lawson Brawley. Waco, TX: Baylor University Press, 2015.

Wright, N. T. The Climax of the Covenant: Christ and the Law in Pauline Theology. Edinburgh: T\&T Clark, 1991.

Wright, N. T. "The Messiah and the People of God: A Study in Pauline Theology with Particular Reference to the Argument of the Epistle to the Romans." D.Phil. thesis. Oxford University, 1980.

Wright, Richard Allen. "Christians, Epicureans, and the Critique of Greco-Roman Religion." ProQuest Dissertations Publishing, 1994.

Young, Norman H. "Paidagogos: The Social Setting of a Pauline Metaphor." NovT 39, no. 2 (1987): 150-76.

Ysebaert, Joseph. Greek Baptismal Terminology: Its Origin and Early Development. Nijmegen: Dekker \& van de Vegt, 1962.

Zeitlin, Solomon. "Slavery during the Second Commonwealth and the Tannaitic Period." JQR 53, no. 3 (1963): 185-218. 